UNIVERSIDADE DE SÃO PAULO

FACULDADE DE FILOSOFIA, LETRAS E CIÊNCIAS HUMANAS DEPARTAMENTO DE SOCIOLOGIA

PROGRAMA DE PÓS-GRADUAÇÃO EM SOCIOLOGIA

JULIANA TONCHE

A construção de um modelo "alternativo" de gestão de conflitos: usos e representações de justiça restaurativa no estado de São Paulo 


\author{
UNIVERSIDADE DE SÃO PAULO \\ FACULDADE DE FILOSOFIA, LETRAS E CIÊNCIAS HUMANAS \\ DEPARTAMENTO DE SOCIOLOGIA \\ PROGRAMA DE PÓS-GRADUAÇÃO EM SOCIOLOGIA
}

\title{
A construção de um modelo "alternativo" de gestão de conflitos: usos e representações de justiça restaurativa no estado de São Paulo
}

\author{
JULIANA TONCHE
}

Tese apresentada ao Programa de Pós-Graduação em Sociologia, do Departamento de Sociologia, da Faculdade de Filosofia, Letras e Ciências Humanas da Universidade de São Paulo, para a obtenção do título de Doutorado em Sociologia.

Orientador: Prof. Dr. Marcos Cesar Alvarez 
TONCHE, J. A construção de um modelo "alternativo" de gestão de conflitos: usos e representações de justiça restaurativa no estado de São Paulo. Tese apresentada ao Departamento de Sociologia da Faculdade de Filosofia, Letras e Ciências Humanas da Universidade de São Paulo, para a obtenção do título de Doutora em Sociologia.

\section{Aprovado em:}

\section{Banca Examinadora:}

Prof. Dr:

Instituição:

Julgamento: Assinatura:

Prof. Dr:

Instituição:

Julgamento: Assinatura:

Prof. Dr: Instituição:

Julgamento: Assinatura:

Prof. Dr: Instituição:

Julgamento: Assinatura: 


\section{AGRADECIMENTOS}

Ao professor e orientador Marcos Cesar Alvarez, obrigada pela confiança, por ter acreditado no projeto, me sinto muito honrada de ter podido contar com sua orientação todos estes anos. Hoje mais que professor e um exemplo de profissional pra mim, é motivo de alegria poder contar com sua amizade também.

Ao Programa de Pós Graduação em Sociologia da Universidade de São Paulo, pelo acolhimento da proposta de pesquisa para este doutorado e pelos quatro anos e meio de apoio para a realização deste projeto; não poderia deixar de registrar aqui meus mais sinceros agradecimentos aos colegas, professores e em especial aos secretários Ângela e Gustavo, sempre muito solícitos, mesmo quando me perdia em meio as burocracias que também fazem parte desta jornada.

À Fundação de Amparo à Pesquisa do Estado de São Paulo (FAPESP), pelo suporte financeiro; sem toda esta estrutura que a fundação poporciona aos seus bolsistas jamais conseguiria desenvolver este trabalho. Não poderia deixar de mencionar também a concessão do estágio sanduíche no exterior, a qual sou muito grata pela oportunidade.

Gustavo T. Taniguti, sem seu apoio e incentivo para prestar o processo seletivo para o doutorado nada disso estaria sendo possível agora, você fez parte deste sonho.

À minha família, Mariangela Moretti Tonche, João Carlos Tonche, Patrícia Tonche, mais uma vez estamos juntos!

Meus amigos mais que especiais Ju Vinuto, Camilo Umaña, Mariana Raupp, Gérald Pelletier, Marcelo Campos da Silveira, Josy Macharia, Claudia Martins, Debora Geraldi, me faltam palavras pra expressar aqui todo o carinho que sinto por vocês, obrigada por fazerem parte da minha vida, vocês estão aqui neste trabalho também.

Mário Villaruel, muito obrigada pela revisão cuidadosa e em tão pouco tempo, também pelas palavras de incentivo neste momento difícil de finalização da tese.

Professor Alvaro Pires, obrigada novamente pela generosidade de me receber no "Labô", já expressei um outros momentos a você o quanto esta experiência marcou a minha vida, obrigada por ter me proporcionado isto. Obrigada pelas conversas, por ter partilhado seus conhecimentos comigo, foi uma honra fazer este sanduíche.

Ana Lucia P. Schritzmeyer e Jacqueline Sinhoretto, gostaria de agradecer a parceria de tantos anos, obrigada por me acolherem em seus grupos de pesquisa, NADIR e GEVAC respectivamente; com toda certeza as discussões proporcionadas pelos encontros foram fundamentais para o desenvolvimento desta tese; a qualidade do trabalho que vocês desenvolvem é uma inspiração para mim.

Sinto neste momento que tantas pessoas mais fazem parte deste trabalho e não estão devidamente citadas aqui, como os interlocutores que me concederam as entrevistas, os facilitadores de justiça, tantos profissisonais que estão na luta buscando novos caminhos para uma transformação em nosso sistema de justiça, fica a sensação de que este agradecimento não é suficiente. 
TONCHE, J. A construção de um modelo "alternativo" de gestão de conflitos: usos e representações de justiça restaurativa no estado de São Paulo. Tese apresentada ao Departamento de Sociologia da Faculdade de Filosofia, Letras e Ciências Humanas da Universidade de São Paulo, para a obtenção do título de Doutora em Sociologia (2015).

\section{RESUMO}

Num contexto de grande demanda aos canais de acesso à justiça, ganha terreno no país a justiça restaurativa conjuntamente a outras formas alternativas de administração de conflitos. Iniciativas relacionadas a estas novas formas de gerir os conflitos estão surgindo nas mais diversas regiões no país, encorajadas por juízes com o objetivo claro de evitar que casos considerados de baixo potencial ofensivo, cometidos em sua maioria por adolescentes de escolas públicas, sejam criminalizados e cheguem ao Judiciário. Esta tese se centra sobre a análise específica de programas alternativos de justiça restaurativa que funcionam no estado de São Paulo. Através de uma pesquisa qualitativa, com base no estudo de caso de programas de justiça restaurativa que funcionam no estado de São Paulo, além de entrevistas com profissionais e observação participante de círculos restaurativos que aconteceram em uma escola na cidade de São Caetano do Sul (SP), argumento como estas iniciativas não estão rompendo com as lógicas do sistema de justiça comum, como a princípio se poderia supor. Em realidade, além de integrarem um quadro em que nosso sistema de justiça criminal continua sendo central, estão aumentando as possibilidades de expansão da rede de controle social, inaugurando configurações inéditas de programas que mesclam o formal e o informal, saber leigo e expertise. Os resultados da pesquisa demonstram também que a justiça restaurativa, a despeito de seu potencial transformador, ainda tem se defrontado com dificuldades para ser efetivamente implantada. As resistências com as quais têm que lidar reportam-se desde às suas fundamentações teóricas, passando pelos próprios operadores do Direito e população que é atendida pelos programas, que não entendem o modelo enquanto expertise (caso dos profissionais do Direito), ou como um benefício para os envolvidos (caso dos adolescentes e familiares participantes), ainda inscritos dentro um marco punitivo em relação à gestão de conflitos.

Palavras-chave: justiça restaurativa, sociologia da punição, administração de conflitos, controle social. 
TONCHE, J. The construction of an "alternative" model of conflict management: uses and representations about restorative justice in the state of São Paulo (Brazil). Thesis (PhD) Faculty of Philosophy, Letters and Human Sciences, University of São Paulo, 2015.

\begin{abstract}
In a context of high demand for access to justice in Brazil, restorative justice programs in conjunction with other alternative forms of conflict management are spreading across the country. Initiatives related to these new ways of conflicts management are emerging in different regions, encouraged by judges with the objective of preventing cases considered of low offensive potential, committed mostly by teenagers from public schools, to be criminalized and to come the courts. This thesis focuses on the specific analysis of alternative programs of restorative justice that are operating in the state of São Paulo (Brazil). Through a qualitative research, based on a case study of restorative justice programs, as well as interviews with professionals and participant observation of restorative circles that happened at a school in the city of São Caetano do Sul (SP), I argue that these initiatives are not breaking with the logic of the ordinary justice system, as it might seem at first. Actually, besides being part of a framework in which our criminal justice system remains central, these iniciatives are increasing the possibilities of expansion of social control network, inaugurating unprecedented programs that are mixing formal and informal, lay knowledge and expertise. The reserach results also show that restorative justice, despite its transformative potential, still has been facing difficulties to be effectively put in practice. The resistances with which they have to deal report since its theoretical foundations, through the law operators themselves and population that is attended by the programs that do not understand the model as an expertise (case of legal professionals), or as a benefit for those involved in the conflict (case of adolescents and participating family members).
\end{abstract}

Keywords: restorative justice; sociology of punishment; conflicts management; social control. 


\section{LISTA DE ILUSTRAÇÕES, TABELAS E GRÁFICOS}

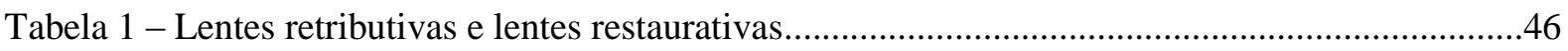

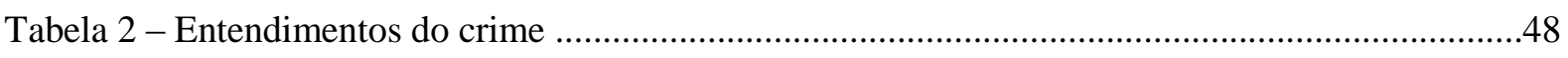

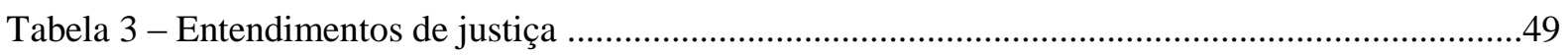

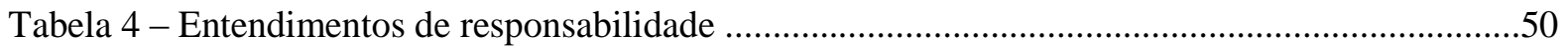

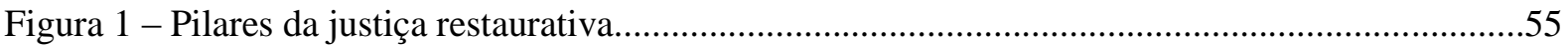

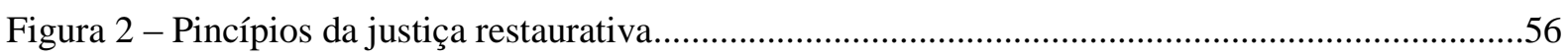

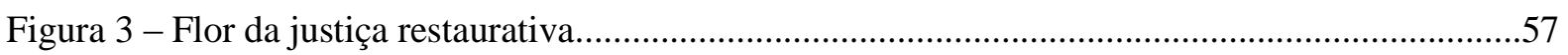

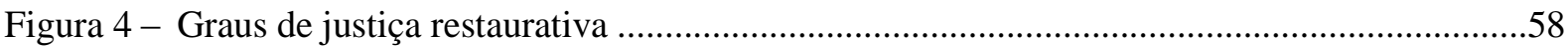

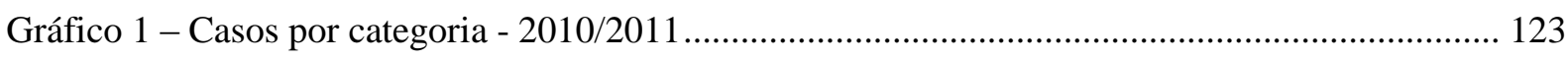

Gráfico 2 - Casos por categoria de conflito, em \% - 2010/2011 .................................................... 125

Esquema 1 - Esquema de controle e apoio na justiça restaurativa ..................................................... 197

Esquema 2 - Esquema de controle e apoio na justiça restaurativa $2 \ldots \ldots \ldots \ldots \ldots \ldots \ldots \ldots \ldots \ldots \ldots \ldots \ldots \ldots \ldots \ldots \ldots \ldots . . . . .198$

Tabela 5: Índice de vulnerabilidade juvenil............................................................................nexos 


\section{LISTA DE ABREVIATURAS}

ABMP - Associação Brasileira de Magistrados, Promotores de Justiça e Defensores Públicos da Infância e da Juventude

AMB - Associação dos Magistrados Brasileiros

BO - Boletim de Ocorrência

CCRA - Corrections and Conditional Release Act

CECIP - Centro de Criação de Imagem Popular

CGJ - Corregedoria-Geral da Justiça

CNJ - Conselho Nacional de Justiça

CNV - Comunicação Não-Violenta

COMAG - Conselho da Magistratura

CREAS - Centro de Referência Especializada de Assistência Social

CSC - Serviço Correcional do Canadá

DF - Distrito Federal

ECA - Estatuto da Criança e do Adolescente

ECOSOC - Conselho Econômico e Social da ONU

FAPESP - Fundação de Amparo à Pesquisa do Estado de São Paulo

FDE - Fundação para o Desenvolvimento da Educação

FFLCH - Faculdade de Filosofia, Letras e Ciências Humanas da USP

FNDE - Fundo Nacional de Desenvolvimento de Educação

FONAME - Fórum Nacional de Mediação

GCI - Grande Cache Institution

GEVAC - Grupo de Estudos da Violência e Administração de Conflitos

IBCCrim- Instituto Brasileiro de Ciências Criminais

IBGE - Instituto Brasileito de Geografia e Estatística

IDCB - Instituto Brasileiro do Direito Comparado

IDESP - Índice de Desenvolvimento da Educação do Estado de São Paulo

ILANUD - Instituto Latino Americano das Nações Unidas para Prevenção do Delito e Tratamento do Delinquente

JR - Justiça Restaurativa

LA - Liberdade Assistida

MJ - Ministério da Justiça

MTR - Making Things Right

NADIR - Núcleo de Antropologia do Direito

NAI - Núcleo de Atendimento Integrado

NEV - Núcleo de Estudos da Violência

OAB - Ordem dos Advogados do Brasil

ONG - Organização Não Governamental

ONU - Organização das Nações Unidas

PAJ - Procuradoria de Assistência Judiciária

PGE - Procuradoria Geral do Estado 
PIB - Produto Interno Bruto

PNUD - Programa das Nações Unidas para o Desenvolvimento

PSC - Prestação de Serviço à Comunidade

PT - Partido dos Trabalhadores

RJDR - Restorative Justice and Dispute Resolution Division

RJU - Restorative Justice Living Unit

RS - Rio Grande do Sul

SP - São Paulo

STF - Supremo Tribunal Federal

STJ - Superior Tribunal de Justiça

TJRS - Tribunal de Justiça do Rio Grande do Sul

TJSP - Tribunal de Justiça do Estado de São Paulo

Unicef - Fundo das Nações Unidas para a Infância

UFSCar - Universidade Federal de São Carlos

USP - Universidade de São Paulo

VORP - Victim Offender Reconciliation Program 


\section{SUMÁRIO}

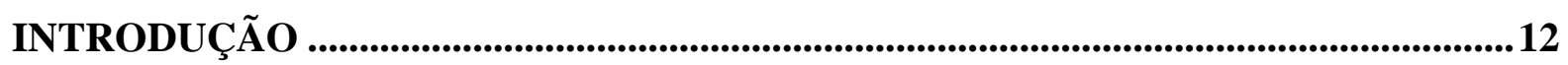

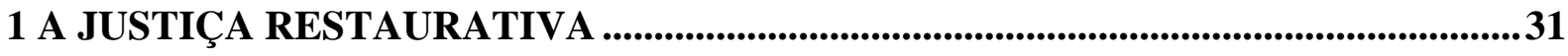

1.1 CONTEXTO

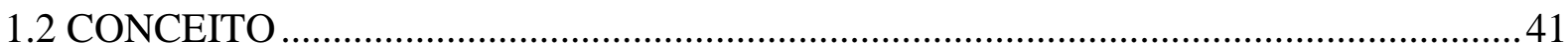

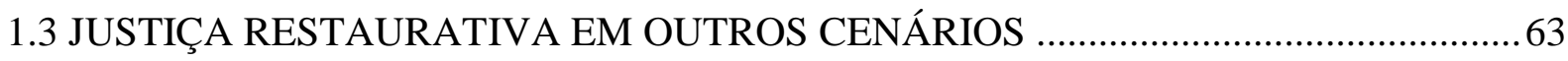

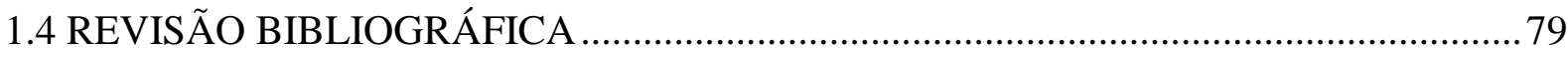

\section{QUESTÕES PROFISSIONAIS RELACIONADAS À JUSTIÇA}

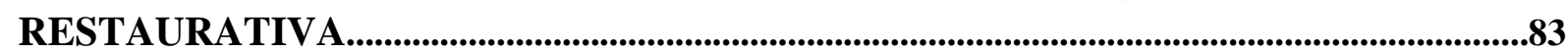

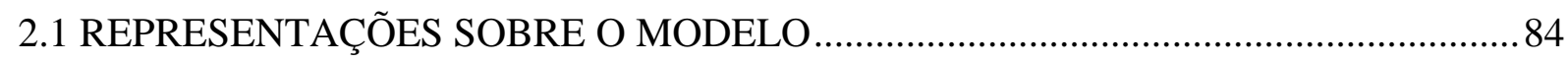

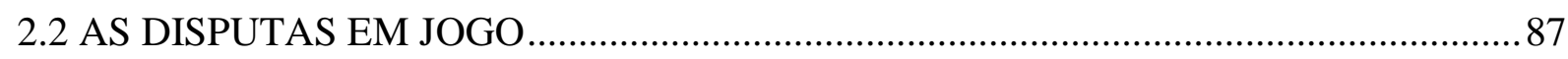

2.3 A ESTRATÉGIA DAS DIFERENTES DEFINIÇÕES...............................................92

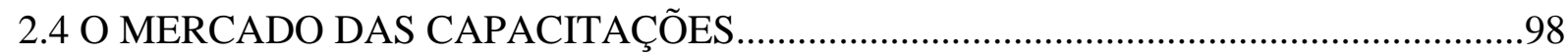

3 OS CÍRCULOS RESTAURATIVOS ...........................................................................114

3.1 O PROGRAMA EM SÃO CAETANO DO SUL ....................................................... 115

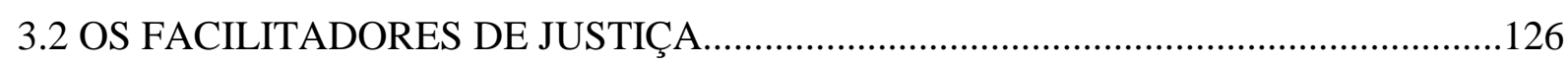

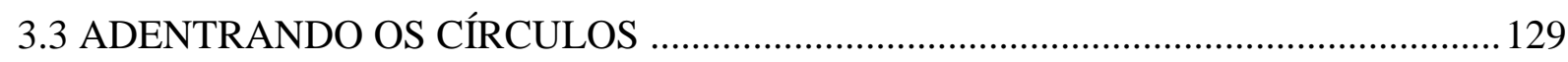

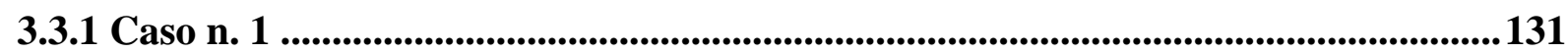

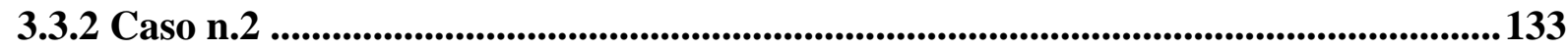

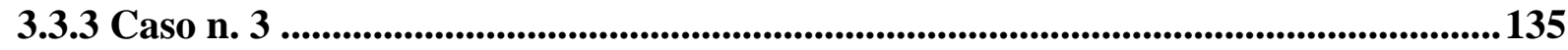

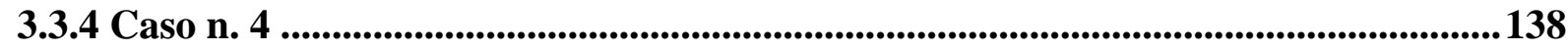

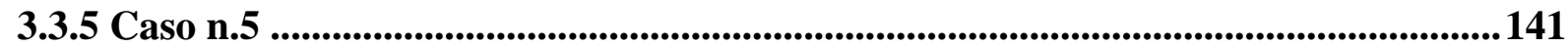

3.3.6 Caso n. 6 ....................................................................................................................... 145

3.4 ALGUMAS CONSIDERAÇÕES SOBRE OS CÍRCULOS OBSERVADOS ................ 146

3.4.1 "Por que você faz isso com a sua família?" .................................................................148

3.4.2 O papel das escolas e o problema dos Boletins de Ocorrência .................................151

3.4.3 Quando a justiça oficial vira uma ameaça .............................................................153

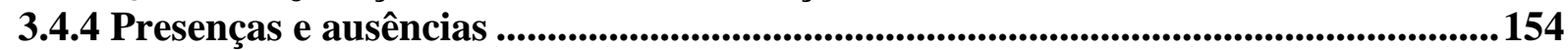

3.4.5 A percepção dos usuários: alternativo ou subalterno? ..............................................156

3.4.6 A busca pela verdade..............................................................................................157

3.5 A SITUAÇÃO DAS TRÊS OUTRAS

REGIÕES. 
4 DUAS HISTÓRIAS SOBRE A JUSTIÇA

RESTAURATIVA............................................................................................................170

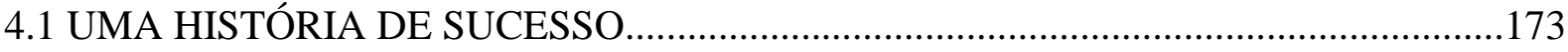

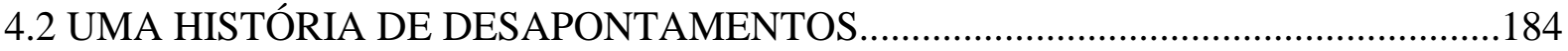

5 PROBLEMATIZANDO A NOÇÃO DE CONTROLE SOCIAL.....................................193

6 CONSIDERAÇÕES FINAIS.....................................................................................................206

REFERÊNCIAS .................................................................................................................211

ANEXOS …...............................................................................................................................................220 


\section{INTRODUÇÃO}

Esta tese de doutorado nasce como o resultado de quatro anos de pesquisa realizadas de acordo com Programa de Pós-Graduação em Sociologia, da Universidade de São Paulo, sob orientação do prof. Dr. Marcos César Alvarez. Este trabalho teve como principal objeto o modelo alternativo de gestão ${ }^{1}$ de conflitos chamado justiça restaurativa.

Mais que a própria justiça restaurativa em si, esta tese incorporou análises baseadas no estudo de caso de programas do estado de São Paulo que aplicam este modelo de justiça, embora o foco principal tenha sido o caso do programa de justiça restaurativa que funciona no município de São Caetano do Sul. Neste local foi realizada uma observação participante que contou com a observação de seis casos de círculos restaurativos ${ }^{2}$, descritos adiante na tese, em um capítulo dedicado especificamente a tratar deste programa.

Foram realizadas também quatorze entrevistas de roteiros semiestruturados com profissionais envolvidos na aplicação deste modelo de justiça no país ${ }^{3}$, além de incursões nas cidades de Campinas, São José dos Campos e região de Heliópolis, na cidade de São Paulo, para conhecer as iniciativas que têm surgido nestas regiões ou que já existiram (caso de Heliópolis).

A participação em workshops e seminários sobre práticas alternativas de administração de $\operatorname{conflitos}^{4}$ foi uma constante durante toda a pesquisa. Embora estas participações não tenham sido previstas inicialmente no projeto de doutorado que embasou o trabalho, estes eventos acabaram se revelando em importantes momentos de interlocução com aqueles que estão empenhados no fomento da pauta da justiça restaurativa em nosso país e destes encontros resultaram contatos importantes para a realização de algumas das entrevistas.

Válido se faz destacar também duas incursões, em dois centros de pequisa no exterior, durante o doutorado e que foram de extrema importância para o desenvolvimento deste trabalho. Estes estágios foram, respectivamente: Visita à École Doctorale de Droit Comparé

\footnotetext{
${ }^{1}$ Agradeço ao professor Ricardo Cappi pelos pertinentes comentários ao trabalho apresentado no Sociology of Law on the move (Canoas, RS, 2015) momento no qual pontuou, entre outros, como os termos gestão e administração de conflitos trazem uma dimensão impessoal à questão. Entretanto, estando ainda na busca por um novo termo, acabei por manter os dois (gestão e administração) para evitar o termo resolução.

${ }^{2} \mathrm{O}$ círculo restaurativo é uma das formas pelas quais a justiça restaurativa pode ser colocada em prática. Como o próprio nome do procedimento indica, geralmente todos os envolvidos no problema ficam dispostos em uma forma de círculo e, ali, contando com a ajuda de um facilitador, procuram formas consensuais de reparação do conflito em questão. Os círculos restaurativos assistidos serão relatados mais adiante na tese, em uma parte do texto dedicada somente à descrição dos casos.
}

${ }^{3} \mathrm{~A}$ lista de entrevistados se encontra no item anexos da tese.

${ }^{4}$ A lista de eventos se encontra no item anexos da tese. 
(Centre Malher) da Universidade Paris I Panthéon-Sorbonne, graças ao convênio firmado entre esta instituição e o Núcleo de Antropologia do Direito (NADIR), da Universidade de São Paulo, sob direção da profa. Dra. Ana Lúcia P. Schritzmeyer, oportunidade possível também dado o apoio institucional e financeiro da Fundação de Amparo à Pesquisa do Estado de São Paulo (FAPESP); e o Estágio-sanduíche de onze meses, também com apoio FAPESP, na Universidade de Ottawa, Canadá, Departamento de Criminologia, com supervisão do docente prof. Dr. Álvaro Pires.

Estes dois estágios foram fundamentais para a concretização deste trabalho e em muito enriqueceram as análises, trazendo novas perspectivas para o objeto de estudo. Entretanto, devido aos limites desta tese, algumas das contribuições não puderam ser completamente incorporadas ao trabalho, restando como pistas importantes para futuros desdobramentos da pesquisa.

$\mathrm{O}$ argumento central aqui apresentado se baseia na constatação de que o modelo de justiça restaurativa não têm se apresentado, nem está se constituindo efetivamente como um modelo destinado a substituir a maneira de pensar das teorias convencionais da pena, a despeito de seu potencial transformador. Ao longo da tese mostrarei, percorrendo diversas dimensões relacionadas ao objeto de análise, os motivos pelos quais isso acontece: a justiça restaurativa da forma como se apresenta (seu autorretrato), as representações sobre o modelo sustentadas pelos profissionais envolvidos e, finalmente, as práticas observadas.

É possível afimar que estes aspectos mencionados (justiça restaurativa em seus conceitos, representações e práticas) se reportam à fragilidade do novo modelo frente ao sistema de pensamento dominante, que constitui nosso atual sistema de justiça criminal; ou seja, a justiça restaurativa, tal qual vem se apresentando e como vem sendo descrita ou aplicada não tem conseguido tensionar suficientemente o sistema de ideias que embasa nosso modelo de justiça corrente.

Feito este primeiro diagnóstico, resta descobrir qual o papel que a justiça restaurativa vem cumprindo nestes espaços onde vêm sendo aplicada. A tese apresentará isto como o anverso da questão. Assim, se a justiça restaurativa não tem sido pensada como alternativa, por que motivos continua existindo, sendo muitas vezes sustentada com discursos de sucesso, apesar de todas as dificuldades para a manutenção dos programas que, como veremos, baseiam-se no voluntarismo dos participantes, contando com poucos recursos e tendo de enfrentar a desconfiança da população atendida por tratar-se de uma maneira mais informal de administração de conflitos. 
Antes de adentrar ao tópico específico sobre em que consiste a justiça restaurativa e qual o problema da pesquisa, é importante destacar que este tema não surgiu com o ingresso no doutorado. De maneira diversa, tem me acompanhado desde minha graduação em Ciências Sociais, na Universidade Federal de São Carlos (UFSCar).

Embora este não seja, portanto, um assunto novo para mim, outros olhares são sempre possíveis e a justiça restaurativa, que a princípio não era o objeto central de minhas preocupações sociológicas, foi ganhando novos contornos e adquirindo maior peso em minhas análises.

No período da graduação, momento em que realizei, na instituição supracitada, uma pesquisa a título de iniciação científica que resultou, por sua vez, na redação de uma monografia de conclusão do curso de bacharel em ciências sociais, a atenção estava voltada para os profissionais do Direito (TONCHE, 2007). O título da monografia é Internacionalização do saber jurídico e poder local: o caso da justiça restaurativa em São Carlos-SP.

Sob a orientação da profa. Dra. Maria da Gloria Bonelli, que me apresentou o subdomínio da sociologia das profissões, empreendi uma pesquisa no município de São Carlos (SP) que procurava estabelecer relações entre a internacionalização do saber jurídico e o poder local. Mais especificamente, tratava-se de analisar qual seria a recepção local a um programa de justiça restaurativa, entendida aqui como uma proposta que fortalece perspectivas de um profissionalismo atrelado às causas sociais, colocando em xeque o modelo formal de profissionalização no mundo do Direito, que apregoa a neutralidade da expertise $^{5}$ e forte demarcação com o campo político.

Nesse sentido, explorei possíveis disputas profissionais, divergências entre aqueles profissionais que se identificavam com uma vertente mais heterodoxa da profissão, em contraste com outros profissionais sempre reportados como detentores de uma visão mais ortodoxa. A justiça restaurativa veio, neste caso, a ser o meio através do qual poderiam ser visualizados estes embates, já que figura como pauta global e faz parte do diálogo de expertises entre profissionais do mundo do Direito, ligados à internacionalização do saber.

O projeto de instalação de um programa de justiça restaurativa na cidade de São Carlos mobilizou operadores do direito na região. Houve muitas posições contrárias à proposta, que de fato não ocorreu, e as manifestações de opiniões, contrárias ou a favor,

\footnotetext{
${ }^{5}$ Para Freidson (2001) a expertise profissional se constitui enquanto uma síntese da ideologia profissional relacionada ao modo de organização do trabalho; é tida como conhecimento especializado de caráter abstrato, produzido nas universidades e obtido através de ensino superior.
} 
traziam à tona questões profissionais relacionadas à reserva de mercado e outras estratégias profissionais mobilizadas; como o caso do procurador geral da prefeitura na época que se alavancou na profissão, galgando novas posições mais próximas do centro de trocas de saber.

No mestrado, realizado na mesma instituição, a pesquisa iniciada anteriormente se ampliou e passei, então, a realizar observações participantes em dois municípios, tentando estabelecer conexões entre os dois contextos no tocante ainda à implantação de programas de justiça restaurativa (TONCHE, 2010).

Se no município de São Carlos a proposta não teve prosseguimento, São Caetano do Sul (SP), por outro lado, desde 2005, tinha (e ainda tem) um programa desta natureza. Esta última localidade foi uma das três escolhidas para sediar um projeto piloto, que implantou o modelo no país com apoio do PNUD e Secretaria da Reforma do Judiciário em 2005.

Em São Carlos, concorreu para a inviabilização do programa o fato de que seu patrono se deslocou na carreira; além disso, também teve papel fundamental a existência e a grande visibilidade de outro programa que já atendia jovens em conflito com a lei no município, o NAI (Núcleo de Atendimento Integrado), desvelando novamente possíveis correlações com o poder local, já que este programa estava atrelado aos mandatos do prefeito petista na época.

Identificou-se em São Carlos também, entre os operadores do Direito, aquilo que James Scott (1990) chama de transcrito oculto, isto é, uma recusa na qual não existem enfrentamentos, oposições, lutas abertas. Havia no lugar o não fazer, a falta de tempo, a falta de "pernas", para que a ideia tivesse prosseguimento, embora o discurso inicial fosse sempre favorável à ideia. Essa foi uma maneira encontrada difusa de escapar, já que não era interessante para estes profissionais discordarem publicamente de uma proposta alternativa com um embasamento teórico e filosófico reconhecido; inclusive internacionalmente, como é o caso da justiça restaurativa e em consonância com a proposta petista em relação à questão do acesso à justiça.

São Caetano do Sul, contrariamente, desde o início mostrou possuir outra configuração institucional e profissional, de modo que passei a discutir a internacionalização do saber jurídico e redes profissionais locais. Diferentemente de São Carlos, em São Caetano do Sul, a pauta da justiça restaurativa desde muito cedo obteve apoio e o programa continua existindo (não sem muitas dificuldades, é verdade) até o presente momento.

Por isso discorri, também, sobre uma possível diluição do impacto à importação e exportação de saber especializado, do global para o local. A força das redes constituídas em torno do novo paradigma se dilui nas localidades, dado que esse saber especializado a respeito do acesso à justiça perpassa algumas instâncias e os compromissos do Estado brasileiro com 
agências internacionais. Assim, aqueles que se situam mais perto do centro das redes se envolvem mais com seus conteúdos e são mais cobrados por eles; por outro lado, estar distante do centro da rede de trocas de expertise permite o uso da distância como forma de resistência e a pauta se dilui em suas capilaridades, como aconteceu no contexto de São Carlos.

Sucintamente, ficou claro nos dois exemplos como as diferentes redes e formas de inserção da pauta da justiça restaurativa foram decisivas para os diversos resultados nos dois lugares: em São Carlos, a pauta chega em meio aos rearranjos políticos sobre o atendimento do adolescente em conflito com a lei; em São Caetano do Sul, a justiça restaurativa chega por uma via de carreiras altamente institucionalizadas.

O título da dissertação, nesse sentido, se fixou como Internacionalização do saber jurídico e redes profissionais locais: um estudo sobre justiça restaurativa em São Carlos e São Caetano do Sul. Se no início, durante a graduação e parte do mestrado, minha pesquisa se baseava em entrevistas com os profissionais, em geral do Direito, envolvidos de alguma forma na questão, quando passei a observar a dinâmica dos procedimentos relacionados a esta nova forma de gerir os conflitos, como sugerido pela banca de qualificação do mestrado, novas possibilidades analíticas surgiram.

O projeto de doutorado foi construído, dessa forma, como um prolongamento das discussões iniciadas anteriormente, possíveis a partir da observação dos círculos restaurativos em São Caetano do Sul (SP). Com base no aporte trazido da sociologia da punição e da administração de conflitos, a proposta de pesquisa apresentada ao Programa de PósGraduação em Sociologia, da Universidade de São Paulo, previa para o doutorado a ampliação do escopo do trabalho de campo, a fim de incluir iniciativas de justiça restaurativa do estado de São Paulo, além do consequente aprofundamento analítico do tema.

Neste trabalho investigo, portanto, o processo de contrução de um modelo alternativo de gestão de conflitos chamado justiça restaurativa em uma localidade, aqui definida, circunscrita ao Estado de São Paulo. A utilização do símbolo aspas para a palavra alternativo no título do trabalho é proposital já que questiona a posição deste modelo em relação ao modelo de justiça comum: seria o modelo de justiça restaurativo realmente alternativo? Seria subalterno? O que seria então?

Além disso, contrariamente à bibliografia que geralmente define a justiça restaurativa como uma maneira alternativa de resolução de conflitos, optou-se pelo termo gestão (ou administração, termo também utilizado em alguns momentos) já que resolução parece indicar 
o fim ou a solução do conflito, o que nem sempre é alcançado - ou mesmo desejado pelas partes.

Mais especificamente, o projeto de doutorado propunha analisar como foi o processo de instalação e como funcionam estes programas de justiça restaurativa, cujo foco de aplicação em nosso país tem sido atender prioritariamente casos de menor potencial ofensivo envolvendo jovens e conflitos que ocorreram em escolas.

Isso poderia ser feito através da observação participante nestes programas, atentando para o atendimento dispensado aos adolescentes e seus familiares e entrevistando profissionais e pessoas da comunidade envolvidas com estas iniciativas.

Em linhas gerais, como objetivo do projeto definiu-se: analisar como se deu a construção de programas de justiça restaurativa no Estado de São Paulo e verificar como tem sido a execução dos mesmos, observando, não somente as práticas em jogo, mas também as representações sobre o modelo e os objetivos que orientaram a inauguração destes programas que contam com a adesão de profissionais do Direito e atores ligados ao Poder Executivo. Dentre os principais objetivos destes programas, destaca-se a tentativa de evitar que casos considerados menos relevantes, por seu baixo potencial ofensivo, cometidos em sua grande maioria por adolescentes de escolas públicas, cheguem até o sistema de justiça comum.

Outro ponto relevante, abordado no projeto de doutorado construído, diz respeito à ideia de inovação sempre associada ao modelo alternativo. Assim, não obstante a justiça restaurativa estar fundamentada no resgate de antigas práticas de mediação de conflitos, ela chega ao Brasil como inovação. E não só, mas talvez como uma das melhores inovações, tanto do ponto de vista qualitativo, por atentar para aspectos que o modelo retributivo teria deixado de lado, como quantitativo, pois poderia ajudar a desentravar os canais oficiais de acesso à justiça pela população.

Todavia, seria possível questionar se realmente colabora com o aumento dos canais de acesso da população à justiça, especialmente a de baixa renda, ou se na verdade tem servido mais como meio de não levar aos trâmites oficiais conflitos considerados pouco importantes ou pouco prestigiosos para a prestação do serviço jurídico. Isso porque, no Brasil, o foco de intervenção da justiça restaurativa tem sido os conflitos escolares que envolvem crianças e adolescentes, pois parte-se da premissa de que estes conflitos, antes resolvidos pela própria escola, estão saindo do entorno escolar e entravando ainda mais um Judiciário já saturado de processos.

Mais ainda, foi possível verificar no percurso do trabalho como a justiça restaurativa na verdade tem se constituído mais como um espaço no qual antigas práticas se consolidam 
que como inovação no campo, como argumentam seus defensores. Cabe questionar então porque razões este quadro se mantém, ou, a que demandas vêm atendendo.

Questiona-se isso pois algumas características do círculo restaurativo observadas, como: a preocupação com a conduta do adolescente, seu rendimento escolar, o envolvimento anterior em conflitos, enxergar o momento como uma oportunidade de educar o jovem, foram alguns dos aspectos que diversos estudos encontraram quando atentaram para as varas da infância e da juventude (MIRAGLIA, 2005). Isso problematiza ainda mais a noção de "alternativa", geralmente associada à justiça restaurativa, se na prática os procedimentos estão sendo orientados por lógicas presentes no sistema de justiça corrente, de acordo com o repertório daqueles que estão conduzindo os círculos restaurativos.

Como tese principal, trabalhei com a ideia de que a justiça restaurativa só seria então efetivamente aceita por permitir que antigas práticas no Direito se mantenham. Ou até mais, pois como foi possível inferir, ela não somente tem aumentado o controle sobre atos que sequer chegavam a ser considerados crimes como também tem permitido que o profissional do Direito delegue para outros operadores, situados numa posição inferior na hierarquia profissional, conflitos que acreditam não fazer parte de sua expertise.

A ideia inicial foi buscar, como base de coleta de dados quantitativos, informações que os próprios programas acumulam, pois em todos os atendimentos são preenchidos formulários a respeito do processo e seus envolvidos. Conjuntamente à análise quantitativa, seria preciso realizar um trabalho de campo pautado em entrevistas em profundidade, a partir de roteiros semielaborados, com mediadores, população atendida e profissionais do Direito envolvidos na questão, além do acompanhamento dos círculos restaurativos. Essa observação seria fundamental para complementar a pesquisa, já que permitiria averiguar como se dá a operacionalização do programa e as dificuldades na sua manutenção; ou seja, como funciona na prática, uma realidade que não se mostra inteira nos trabalhos de divulgação e publicações oficiais daqueles diretamente envolvidos com as iniciativas.

Esses foram alguns dos principais pontos presentes no projeto de doutorado que orientaram a pesquisa realizada nestes anos de doutoramento. Considerando o desenho inicial do projeto, é possível afirmar que houve em seu percurso significativas mudanças e, na mesma medida, também dificuldades. Uma primeira mudança diz respeito aos locais de realização de trabalho de campo; outra se refere aos dados quantitativos.

A pesquisa se redesenhou quanto às regiões a serem analisadas, visto que em alguns locais em que estavam previstas idas a campo os programas não funcionam mais (caso de Heliópolis e Guarulhos). Ao mesmo tempo, outras regiões surgiram como importantes 
interlocutores, como São José dos Campos e Campinas. O primeiro resultado disso é que São Caetano do Sul permanece sendo o principal local analisado. Isso porque, além dos contatos que permaneceram dos estudos anteriores, esta iniciativa se mantém como principal na região, já que foi um dos três projetos-piloto de 2005, funcionando até a presente data.

Em relação aos dados quantitativos, não consegui acesso a eles, o que, por sua vez, leva ao desenvolvimento de outro problema importante de pesquisa, abordado neste trabalho também, que são as dificuldades surgidas em campo. Tentarei demonstrar nesta tese como estas dificuldades que surgiram podem ser consideradas como importantes dados de pesquisa. Vistas sob outro ponto de vista, as dificuldades dizem muito a respeito do objeto pesquisado.

A tentativa de interrogar sobre os dados do programa, para que pudessem ser citados no trabalho, dificultou muito minha inserção num campo já bastante tenso e meu contato com uma mediadora de São Caetano do Sul, principal interlocutora no local, restou bastante prejudicado. Esta mediadora, ou facilitadora de justiça, forma como se autodenominam aqueles que conduzem os círculos, confidenciou-me um dia que perguntou ao juiz responsável pelo programa se poderia me fornecer mais dados do programa ao que ele teria respondido: "Dados não, não pode, você sabe o que pode e o que não pode fazer".

Outra dificuldade, decorrente desta situação, é a própria falta de diálogo com o juiz e com a facilitadora, que passou sistematicamente a me evitar. Isso, consequentemente, prejudicou a observação dos círculos, já que a facilitadora não avisava mais quando atenderia um caso. Tentei, também, diversas vezes, marcar uma entrevista com o juiz e não obtive sucesso. Porém, mesmo com estas adversidades, consegui assistir a realização de alguns círculos restaurativos no local. Seria preciso questionar, no entanto, se não teria havido uma pré-seleção dos casos, já que, em mais de uma vez, ao chegar ao local para assistir a um círculo, estavam sendo realizados outros atendimentos sobre os quais eu não havia sido informada.

Pude notar, fazendo uma comparação entre os trabalhos de campo realizados no mestrado e agora no doutorado, como o campo mudou em apenas alguns anos: se antes tinha maior acesso e os interlocutores pareciam mais à vontade e até mesmo ansiosos por me contar as novidades em relação ao modelo alternativo e os programas, agora um clima de desconfiança paira entre os envolvidos com as iniciativas. Quando aceitam me conceder uma entrevista, sou muito mais questionada que antes: os entrevistados querem saber o que faço, o que estudo e com quem já conversei sobre o assunto.

Sobre esta questão, é preciso retroceder um pouco no tempo para que se possa melhor compreender a situação. Desde 2005, data do início dos programas-piloto de justiça 
restaurativa no Brasil, muitos trabalhos foram publicados no âmbito acadêmico sobre o modelo e sobre os programas atrelados a ele que funcionam no país. Chama a atenção o fato de que aqueles envolvidos com os programas tiveram a oportunidade de acompanhar o resultado destas pesquisas, como relatado em entrevista, e o resultado da leitura destes trabalhos desfavorece as pesquisas em andamento ou aqueles pesquisadores que querem se dedicar ao tema; pois, como uma interlocutora confidenciou, os profissionais participantes dos programas não gostaram daquilo que leram - o tom crítico dos trabalhos não agradou àqueles que estão empenhados no fomento dos programas. O resultado imediato disso é um fechamento cada vez maior do campo para os pesquisadores, o que é um aspecto negativo a ser considerado; por outro lado, esta é uma situação privilegiada, para se analisar de um ponto de vista sociológico, a interação que ocorre in loco entre academia e programas de administração alternativa de conflitos.

Outro exemplo é a situação em Porto Alegre, local onde existe também um programa de justiça restaurativa (foi instalado ali um dos três projetos-piloto). Neste local, para que um pesquisador possa acompanhar o programa, deve atualmente passar por um tipo de avaliação, ou seja, seu projeto deve ser analisado e depois passa-se por uma situação de entrevista.

Como os projetos de justiça restaurativa ainda estão muito ligados à pessoa responsável por sua implantação, o que na maior parte das vezes são os juizes da área da infância e juventude de suas localidades, existe essa preocupação com a reputação dos envolvidos e do próprio programa, que deve seguir sempre apresentando resultados positivos.

Além disso, é digno de nota o fato de que uma das principais críticas dirigidas às iniciativas diz respeito à ausência de metodologias de avaliação dos programas e à falta de divulgação dos resultados dos mesmos, o que dificulta enormemente o trabalho dos avaliadores ou pesquisadores que se interessam pela temática. A falta de divulgação dos resultados não impede, entretanto, que sejam utilizados em publicações próprias daqueles profissionais, especialmente do direito, diretamente envolvidos na questão, o que nos leva, por sua vez a questionar a própria validade desses dados.

Outro ponto não previsto anteriormente, no projeto de doutorado, mas que foi se revelando ao longo da pesquisa, diz respeito à importância dos grupos de capacitação de mediadores ou facilitadores de justiça. Nesse sentido, cabe acrescentar como não estavam previstas também as diversas participações em seminários e workshops sobre gestão alternativa de conflitos, mas ao longo do tempo estes eventos foram se revelando como importantes espaços etnográficos e de contatos para a realização de entrevistas. 
As reflexões mais atuais da pesquisa foram apontando na direção de mostrar como diversos grupos têm se apropriado da justiça restaurativa. O trabalho desenvolvido cada vez mais se aproximou de um estudo que verificou também as diversas apropriações feitas pelos grupos do modelo alternativo e de particularmente como o Direito se apropriou da questão sob a forma dos projetos. A justiça restaurativa criou um campo para a atuação de diversos segmentos e é possível pensar em que medida ela não se tornou um nome, uma marca que chama a atenção e os diferentes grupos se utilizam disso para, muitas vezes, realizarem projetos que na verdade nem dizem respeito ao modelo restaurativo.

São muitos os grupos profissionais envolvidos nessas iniciativas e o tipo de envolvimento desses atores também é bastante diverso: são juízes; promotores; advogados; professores; psicólogos; assistentes sociais; dentre outros. Existem hoje, como citado anteriormente, grupos especializados na realização de capacitações de mediadores ou facilitadores de justiça; criou-se, dessa forma, um nicho para o desenvolvimento de um novo tipo de mercado e de expertise. Se eu estava relutante em usar a palavra mercado, para me referir ao espaço de atuação desses grupos de capacitação (ainda que tudo o que eu observasse me levasse a crer que se tratava disso), a palavra emergiu de uma própria interlocutora durante uma entrevista; esta questão será tratada adiante na tese (capítulo dois).

Além disso, cada vez mais cidades em diversas regiões do país têm articulado experiências veiculadas à justiça restaurativa (ao menos em teoria ou apenas usando explicitamente o nome). Mas vale a pena ressaltar que o incremento no número de iniciativas não significa que a justiça restaurativa está se expandindo efetivamente, uma vez que esse aumento se dá com perdas, ou seja, muitos programas deixaram de existir em vários locais. Mais que isso, como poderemos acompanhar no desenrolar da tese, muitos profissionais se deslocam em suas carreiras, alcançando novas posições a partir do envolvimento com a questão da justiça restaurativa, situação que prejudica a continuidade dos programas demonstrando também não ser a justiça restaurativa aquela que alcança novas dimensões, mas sim aqueles que estão nas redes que as encadeia.

Os novos programas que têm surgido são acompanhados pelas varas de infância e juventude de suas respectivas localidades, mas têm sido bastante comum projetos ligados a secretarias da educação e de assistência social. Parece, nesse caso, que os alvos dos programas continuam sendo os adolescentes e os conflitos relacionados ao espaço das escolas.

Uma pesquisa que se propõe, portanto, a estudar o tema, necessariamente, tem de lidar com um meio em que diferentes grupos profissionais mobilizam o tempo todo estratégias, ao mesmo tempo em que ressignificam o próprio conceito de justiça restaurativa. As 
representações acerca do modelo em geral sempre o valorizam de uma forma bastante positiva, em contraste com a justiça oficial que é sempre reportada como deficiente, morosa, cara. Veremos, também, adiante no texto, como o próprio manuseio de significados em torno do novo modelo pode ser visto como uma estratégia empregada pelos agentes para contornar as críticas.

Essa questão da conceituação em torno do modelo de justiça restaurativa foi um dos desafios da pesquisa. É importante definir o que é a justiça restaurativa, objeto desta análise, mas não se constitui tarefa fácil caracterizá-la. Não existe uma definição única e acabada e pode-se, inclusive, dizer que sequer haverá, pois as diversas discussões sobre sua conceituação são parte vital do campo.

Após quase dez anos estudando o tema, entrevistando agentes envolvidos na questão e participando ou assistindo a workshops, seminários, congressos, simpósios sobre justiça restaurativa, é possível dizer que nestes espaços de discussão, acadêmicos ou de divulgação, os agentes afirmam sempre saber o que é a justiça restaurativa, mas ninguém diz realmente o que ela é e as vozes dissonantes são rotuladas como falta de conhecimento.

Como exemplo da falta de uma definição única do modelo, ao mesmo tempo em que parece haver um consenso sobre a falta de um consenso em torno de sua conceituação teórica, no website do Serviço Correcional do Canadá ${ }^{6}$ podemos encontrar o seguinte excerto:

\footnotetext{
"Enquanto não há uma única definição universal para a Justiça Restaurativa, elementos comuns são compartilhados entre aquelas que exitem. Estes elementos comuns, frequentemente referidos como valores e princípios da Justiça Restaurativa, são fundamentais para garantir que os valores e princípios da Justiça Restaurativa permaneçam consistentes com a filosofia fundadora desta abordagem ,7.
}

Sobre a mesma questão, Howard Zehr, que é considerado um dos autores mais importantes no tema da justiça restaurativa, tendo sido aquele que mais colaborou para sua sistematização enquanto um modelo e sua divulgação mundial, argumenta:

\footnotetext{
${ }^{6}$ O Canadá é um dos países referência quando falamos em justiça restaurativa. Tratarei melhor da questão adiante, visto que meu estágio sanduíche foi realizado neste país.

${ }^{7}$ No original (tradução livre da autora): "While there is no single universal definition for Restorative Justice, common elements are shared between those that exist. These common elements often referred to as Restorative Justice values and principles, are fundamental to ensuring that Restorative Justice values and principles remain consistent with the founding philosophy of this approach". http://www.csc-scc.gc.ca/restorative-justice/0030050007-eng.shtml (acessado em 15/12/2014).
} 
"Como, então, devemos definir justiça restaurativa? Embora haja um entendimento geral sobre seus contornos básicos, os profissionais do ramo não conseguiram chegar a um consenso quanto a seu significado específico. Alguns de nós questionam a utilidade de uma definição, ou mesmo devidam da sabedoria de se fixar uma tal definição. Mesmo reconhecendo a necessidade de princípios e critérios de qualidade, preocupa-nos a arrogância e a finalidade de estabelecer uma conceituação rígida". (ZEHR, 2012, p. 48]

Entre os autores parecer haver uma tendência a definir o modelo mais através de valores e princípios. O Conselho Econômico e Social da ONU (ECOSOC) a define da seguinte forma: "todo programa que se vale de processos restaurativos para atingir resultados restaurativos" (ONU, Resolução 12/2002). Também é uma definição bastante vaga, como podemos perceber.

Embora este tema das diversas definições sobre a justiça restaurativa seja abordado no capítulo 1 da tese de maneira mais aprofundada, vale a pena ressaltar que muitos destes valores atrelados à justiça restaurativa, como o respeito, o diálogo, processos mais inclusivos, apoio, entre outros, nos remetem às formas tradicionais pelas quais populações autóctones resolviam seus conflitos.

Os autores convergem no reconhecimento de que muitos dos aspectos fundadores da justiça restaurativa vieram de povos tradicionais, nos quais existiam como um sistema de "justiça", que devia atender o conjunto de situações problema com os quais tinham que lidar. Também é possível inferir que estas formas mais tradicionais de gestão de conflitos aproximam-se mais do que hoje conhecemos por justiça restaurativa do que em relação ao nosso atual sistema de justiça criminal, se tivéssemos de estabelecer uma comparação.

Entretanto, no momento em que a justiça restaurativa foi levada a se confrontar com a justiça penal moderna, evidentemente entrou em primeiro lugar e mais rapidamente nos espaços de justiça voltados para as crianças e adolescentes, onde já havia uma pré-disposição para recebê-la, dado o seu caráter mais pedagógico e a ausência do teor punitivo atrelado às teorias da pena em relação à justiça para adultos (ou maior ausência, em alguns casos).

Neste momento, é possível dizer que a justiça restaurativa desenvolveu aquilo a que denominarei aqui de "autorretratos" de si mesma, através, é claro, dos diversos autores que passaram a dar cada vez mais atenção a ela. Pode-se dizer que desenvolveu, portanto, uma forma de se apresentar e, através dessas formas de apresentação algumas fronteiras foram traçadas, demarcações em relações a outras formas de administração de conflitos.

O problema, a ser abordado nesta tese, é que neste momento ela não se apresentou como um modelo de justiça concebido para substituir a intervenção clássica do direito 
criminal, e assim tem sido desde então. Dessa forma, a justiça restaurativa limitou, nesta operação, o seu próprio potencial crítico e a própria generalização do modelo.

Para exemplificar o argumento que quero apresentar aqui, me reportarei novamente ao próprio Howard Zehr: em seu livro "Justiça Restaurativa" (2012), tradução do conhecido livro do autor "The little book of Restorative Justice", o autor começa definindo a justiça restaurativa pelo que ela não é:

“- A JR não tem como objeto principal o perdão ou a reconciliação;

- A JR não é mediação;

- A JR não tem por objetivo principal reduzir a reincidência ou as ofensas em série;

-A JR não é um programa ou projeto específico;

- A JR não foi concebida para ser aplicada a ofensas comparativamente menores ou ofensores primários;

-A JR não é algo novo nem se originou nos Estados Unidos;

-A JR não é uma panaceia nem necessariamente um substituto para o processo penal;

-A JR não é necessariamente uma alternativa ao aprisionamento;

- A JR não se contrapõe necessariamente à justiça retributiva;"

(Fonte: Zehr, 2012, p.18)

Essas sentenças como um todo, mas em especial as que afirmam que a justiça restaurativa não é um substituto para o processo penal, não é uma alternativa à prisão e não se contrapõe necessariamente à justiça retributiva deixam claro como a justiça restaurativa não tem sido pensada como verdadeira alternativa em relação ao modelo de justiça comum.

Então, à pergunta: "Por que a justiça restaurativa não pode reconstruir completamente, não nos permite construir uma nova teoria da intervenção penal no seu conjunto?" Poderíamos responder que o motivo reside no próprio fato de ela se apresentar dessa maneira, paralela, ligada aos métodos característicos do sistema de justiça corrente; foi, portanto, essa maneira dela se auto-caracterizar que limitou sua própria potencialidade crítica. Dito de outra maneira, o alcance de sua crítica já estava comprometido desde seu "nascimento". E estas limitações não se restrigem apenas à dimensão conceitual, como veremos posteriormente, ao contrário, se estendem pelas aplicações práticas que, ao invés de valorizarem o modelo alternativo, caem na armadilha de acabarem reforçando o sistema de justiça oficial com o qual concorrencia. 
Ainda que possamos apontar estes, entre outros dilemas, ou ainda dirigir outras críticas à justiça restaurativa, é bastante significativo que o tema deste modelo alternativo de gestão de conflitos continue em franca expansão. Significativo também é o fato de que, ao menos no Brasil, sociólogos ainda têm dado pouca atenção ao assunto. Visto por alguns como uma grande inovação no campo da administração de conflitos, ou apenas como algo marginal no campo por outros, o fato é que pesquisadores do Direito têm dado maior atenção ao tema.

A justiça restaurativa é um tema recorrente dentre as notícias disponíveis nas páginas do site do Tribunal de Justiça de São Paulo ${ }^{8}$, da Escola Paulista da Magistratura ${ }^{9}$ que criou, inclusive, um curso sobre o tema, e do Supremo Tribunal Federal ${ }^{10}$.

No dia 14 de agosto de 2014, uma notícia veiculada pelo portal de notícias na internet G1 da Globo diz que o presidente do Supremo Tribunal Federal (STF) e do Conselho Nacional de Justiça (CNJ), ministro Ricardo Lewandowski, assinou um protocolo de cooperação com a Associação dos Magistrados Brasileiros (AMB) para divulgar e promover a prática da justiça restaurativa.

Para Lewandovski, seria preciso mudar a cultura da magistratura no Brasil, para restaurar o "equilíbrio da paz social". Segundo o ministro, é equivocada a mentalidade de que problemas sociais serão resolvidos pela sua judicialização. Não à toa, a conciliação também foi inserida neste protocolo, incentivada a ser utilizada como um procedimento a ser tomado antes da judicialização do conflito.

De acordo com a notícia o ministro teria dito: "Para que nós possamos dar conta desse novo anseio de Justiça, dessa busca pelos direitos fundamentais, é preciso mudar a cultura da magistratura. Parar com essa mentalidade que todos os problemas sociais serão resolvidos pela judicialização". A notícia prossegue com mais afirmações do ministro:

\footnotetext{
${ }^{8}$ Notícia de 15/12/2008: "Programa 'Justiça e Educação -Uma Parceria para a Cidadania' será ampliado"; de 07/04/2008: "Professor norte-americano fala sobre Justiça Restaurativa no TJSP"; de 02/04/2008: "TJSP recebe um dos mentores da Justiça Restaurativa". Notícias disponíveis no site do TJ: <www.tjsp.jus.br〉. Acessado em 08/03/2010

${ }^{9}$ Algumas das notícias mais recentes veiculadas pelo website da instituição: EPM iniciará Núcleo de Estudos em Justiça Restaurativa (24/10/2014); TJSP assina protocolo de cooperação sobre Justiça Restaurativa em Brasília (15/08/2014); Implantação de núcleos irradiadores de Justiça Restaurativa é debatida na EPM (30/05/2014); Inscrições para o curso "Introdução à gestão de projetos de Justiça Restaurativa" vão até o dia 24 (16/04/2014); Para ver mais notícias: http://www.epm.tjsp.jus.br/Internas/Noticias.aspx acessado em 17/12/2014.

${ }^{10}$ Algumas das notícias veiculadas pelo website da instituição: Programa Artigo $5^{\circ}$ discute a justiça restaurativa (29/08/2012); Rádio Justiça destaca curso destinado a detentos que ensina meios alternativos para solução de conflitos (23/04/2012); Justiça Restaurativa é o tema do Fórum desta sexta-feira, na TV Justiça (19/02/2010). Ministra Ellen Gracie recebe convite para abrir ciclo de palestras sobre Justiça Restaurativa (04/03/2008) Para ver mais notícias: http://www.stf.jus.br/portal/cms/listarNoticiaSTF.asp acessado em 17/12/2014.
} 
"É preciso que ele [o juiz] tenha não apenas a inteligência técnica, mas a sensibilidade e inteligência social. [É preciso] procurar, antes de fazer incidir uma justiça punitiva, repressiva, buscar, de certa forma, restaurar aquela situação de rompimento do equilíbrio da paz social", completou.

O presidente da AMB, João Ricardo Costa, comemorou a assinatura do protocolo e afirmou que, no processo "tradicional", o juiz não conhece a realidade social do infrator: "A justiça restaurativa é um método de reunião das partes e restauração dos conflitos. Há também uma discussão do que levou aquele agente a cometer o delito. No processo tradicional, nós não temos conhecimento da realidade de cada um", disse". Notícia disponível em:

http://g1.globo.com/politica/noticia/2014/08/presidente-do-cnj-assinaacordo-para-incentivar-justica-restaurativa.html (acessado em 15 de agosto de 2014).

Outro exemplo de notícia que sinaliza a tentativa de expansão da justiça restaurativa no Brasil e mostra sua visibilidade cada vez maior foi veiculada pelo Tribunal de Justiça do Estado do Rio Grande do Sul em 21/10/2014.

O texto divulgado afirma que "pensando na consolidação e fortalecimento das práticas autocompositivas, o Conselho da Magistratura (COMAG) do Tribunal de Justiça do Rio Grande do Sul (TJRS) aprovou, nesta tarde, a instauração do Projeto Especial Justiça Restaurativa no $1^{\circ}$ Grau de jurisdição. O Juiz de Direito Leoberto Narciso Brancher será o coordenador estadual do projeto, que ficará a cargo da Corregedoria-Geral da Justiça (CGJ)". Este juiz foi o responsável pela iniciativa do programa de justiça restaurativa de Porto Alegre, RS, um dos três projetos piloto (junto com São Caetano do Sul), que deu origem ao projeto Justiça para o Século XXI.

"Visando ir além do sistema judicial para alcançar a resolução de
conflitos e a pacificação social, a Justiça Restaurativa tem seu espaço
ampliado no âmbito do Judiciário Estadual gaúcho. (...) O Projeto
Especial Justiça Restaurativa vai atuar no planejamento de uma
estratégia de implantação e de utilização do paradigma restaurativo
em ramos especiais da prestação jurisdicional, tais como infância e
juventude, violência doméstica e familiar contra a mulher, execução
penal, direito de família. A sede do projeto será em Caxias do Sul.
(...) O Juiz Leoberto Brancher coordena, em Caxias do Sul, o Núcleo
de Justiça Restaurativa. No início deste ano, o município tornou a
prática uma política pública, através da Lei Municipal no $7.754 / 2014$.
O magistrado foi também o responsável pela implantação da Justiça
Restaurativa na Capital, em 2005 . Segundo ele, a experiência de 10
anos de implantação oficial da Justiça Restaurativa no Brasil tem
servido para atestar não apenas a efetividade das práticas restaurativas
na resolução de conflitos, mas, sobretudo, para demonstrar também o 
potencial desses novos conceitos e metodologia em produzir engajamento das comunidades e transformações em nível institucional. Tenho sempre repetido que o desafio da Justiça do Século 21 não é apenas de estrutura ou de gestão, mas, antes de tudo, é uma questão de concepção, afirma o magistrado. Essas concepções, baseadas em participação da vítima e das comunidades, foco na reparação dos danos e corresponsabilização ativa dos envolvidos, agora serão colocadas a serviço da inovação da Justiça gaúcha."

Disponível em:

http://www.tjrs.jus.br/site/imprensa/noticias/?idNoticia=251596

(acessado dia 23 de outubro de 2014).

No primeiro capítulo da tese, chamado A justiça restaurativa, farei uma exposição mais detalhada deste modelo alternativo de justiça. Percorrendo autores que discutem o tema, num campo ainda em formação, pretendo mostrar o que a teoria nos diz sobre a justiça restaurativa, que chega a ser considerada por muitos um novo paradigma. Assim, busca-se responder: qual seu embasamento teórico-filosófico, em que consistem seus procedimentos, quais os principais pontos em que os autores convergem e, por outro lado, quais as principais divergências e críticas - estas são algumas das questões que tentarei contemplar neste momento do texto.

Ainda neste capítulo contextualizarei o modelo de justiça restaurativa, discorrendo um pouco sobre suas origens e aplicação em outros países (focando principalmente no contexto canadense como exemplo de um caso internacional) e como isto também se encaixa na questão do acesso à justiça, especificamente no Brasil.

No segundo capítulo, intitulado Questões profissionais no campo da justiça restaurativa, pretendo considerar as diversas representações que os profissionais envolvidos com a justiça restaurativa detêm sobre este modelo, representações que, na maior parte das vezes, parecem contrastar com as práticas observadas. Além disso, as representações são sempre muito idealizadas e em oposição ao modelo de justiça comum, ou seja, a justiça restaurativa está sempre apoiada sobre o modelo com o qual teoricamente concorrencia, o modelo de justiça oficial, ou, mais ainda, a justiça restaurativa deveria ser o que o modelo retributivo não é.

Em seguida, no mesmo capítulo analisarei ainda as diversas disputas profissionais que estão em jogo nestes espaços compostos por diferentes grupos, que chegam muitas vezes a rivalizarem entre si; também a negociação de significados praticada pelos profissionais 
envolvidos com a justiça restaurativa no país e de como isto pode ser interpretado como uma forma estratégica de agência destes indivíduos. Finalmente, será abordado também o novo mercado das capacitações.

No terceiro capítulo da tese, chamado Os círculos restaurativos, serão discutidos aspectos daquilo que se constituiu como um dos focos principais do estudo: o ritual dos círculos restaurativos praticados no programa de justiça restaurativa de São Caetano do Sul; além de também ficarem indicadas algumas possibilidades de análise para a interpretação dos casos descritos.

Neste capítulo dedicado a abordar os círculos, é possível não somente compreender como são conduzidos os rituais de administração dos conflitos neste local, mas também entender como o programa funciona de uma maneira geral.

No quarto capítulo: Duas histórias sobre a justiça restaurativa, o objetivo é contrastar dois relatos diferentes a respeito da justiça restaurativa, a partir de dois interlocutores da pesquisa que ocupam, ou ocupavam, posições diferentes no campo brasileiro em torno do modelo. Estas histórias exemplificam o caso de como uma pauta como a justiça restaurativa foi pensada inicialmente por aqueles que ocupavam posições centrais na rede que a apóia para ser o início de uma grande transformação em termos de administração de conflitos, apostando no sucesso dos programas, algo que contraria o discurso de sucessivas decepções como relatado por outra interlocutora que ocupa uma posição periférica no campo, trabalhando como assistente social em um dos programas analisado.

Em seguida, abordarei no quinto capítulo, denominado Controle social, a questão sociológica do controle social que emergiu no trabalho de campo e foi bastante presente durante toda a pesquisa, tentando relacioná-la com as noções de controle social informal e vergonha reintegrativa (dois conceitos bastante utilizados por pesquisadores no tema da justiça restaurativa).

A respeito da noção de controle social, antecipando uma questão que tentarei abordar de forma mais aprofundada naquele capítulo, já destaco a existência de uma linha de discussão que acredita que tal modelo de justiça faz parte de um movimento que busca, sobretudo, exercer um controle social, já que ele compreende os conflitos como situações essencialmente negativas que devem ser combatidas (NADER, 1994a, 1994b; SCHUCH, 2006).

Após os cinco capítulos apresento as Considerações finais da pesquisa. Neste momento do texto é retomado o argumento principal da tese, de que a justiça restaurativa, ao entrar para as engrenagens do nosso sistema de justiça, que funciona de forma desigual para 
as diferentes camadas da população, acaba integrando o quadro; assim, ainda que entre subordinada, acaba reproduzindo desigualdades na distribuição de uma justiça seletiva e hierárquica.

Outra consequência é que ela não têm se apresentado como candidata para a construção de uma nova teoria de intervenção do direito penal. Tendo, pois, caracterizado ao longo da tese que a justiça restaurativa não tem se constituído como alternativa para a substituição das teorias convencionais da pena que embasam nosso sistema de justiça, podemos também afirmar que está sendo subutilizada. Dessa forma, a justiça restaurativa poderia fazer contribuições importantes na medida em que poderia ir mais além e tratar um maior número de situações do que o direito penal atualmente a autoriza a fazer. Essa é a sua contrapartida: ela não pode e nem almeja substituir o atual sistema vigente, em compensação, mesmo dentro dos seus limites, poderia ter seu campo de atuação estendido, o que não vem ocorrendo. De maneira contrária, vem sendo aplicada a casos considerados de baixo potencial ofensivo, casos sobre os quais os juízes mantêm controle ao mesmo tempo em que delegam a administração destes mesmos conflitos para outros profissionais subordinados na hierarquia profissional.

Em relação às principais referências de estudo para a análise, além de produções que versam especificamente sobre a justiça restaurativa, que, diga-se de passagem, em sua maioria estão ainda circunscritas ao domínio do Direito, buscou-se dialogar com trabalhos vinculados à sociologia da punição e à sociologia da administração de conflitos.

Autores como Schuch (2006) e Nader (1994a; 1994b) mostram como os objetivos do fim do conflito e alcance da paz, como propostos pela justiça restaurativa, podem ser entendidos como uma outra forma de controle social. Na mesma linha de pensamento, existem aqueles que enxergam nestes programas de justiça alternativos um movimento de transferência de responsabilidades para a esfera da comunidade representando outra forma de controle social a partir da construção ética de novos indivíduos (ROSE, 2000; OLIVEIRA, 2006).

Estas são apenas algumas das contribuições teóricas que considero importantes para uma reflexão crítica acerca dos métodos alternativos de gestão de conflitos e que veremos com mais detalhes nos capítulos a seguir.

A participação no Seminário Temático Michel Focault - Cursos no Collège de France, coordenado pelo professor Marcos César Alvarez e sediado no NEV (Núcleo de Estudos da Violência) e FFLCH (Faculdade de Filosofia, Letras e Ciências Humanas), da 
Universidade de São Paulo, também foi importante já que possibilitou o aprofundamento da leitura das obras de Foucault, que é um autor referência para o estudo.

A ida regular aos encontros dos dois grupos de estudo dos quais faço parte também muito contribuiu para as reflexões foram construídas ao longo da pesquisa. Os grupos são: GEVAC (Grupo de Estudos da Violência e Administração de Conflitos), da Universidade Federal de São Carlos (UFSCar); e NADIR (Núcleo de Antropologia do Direito), da Universidade de São Paulo (USP). 
CAPÍTULO 1:

A JUSTIÇA RESTAURATIVA 
Neste capítulo da tese, o foco reside sobre o que a teoria nos diz a respeito da justiça restaurativa. Como explicitado anteriormente, são três as principais dimensões ou aspectos sobre este modelo alternativo de administração de conflitos a serem abordados neste trabalho: a teoria sobre este modelo alternativo de gestão de conlfitos, as representações que os profissionais envolvidos com os programas detêm e as práticas observadas.

Neste momento do texto atentaremos para o primeiro destes pontos, ou seja, a teoria mostrando também como o modelo define a si próprio, ou o que chamo aqui de seu “autorretrato". Assim, através de autores que discutem o tema (num campo dinâmico e ainda em formação), veremos em que consiste a justiça restaurativa, que chega a ser considerada por muitos um novo paradigma. Ao longo do capítlo busca-se responder as sguintes questões a respeito do modelo: qual seu embasamento teórico-filosófico, em que consistem seus procedimentos, quais os principais pontos em que os autores convergem e, por outro lado, quais as principais divergências e críticas.

Ainda neste capítulo, contextualizarei o modelo de justiça restaurativa, verificando como ela se encaixa na questão do acesso à justiça, especificamente no Brasil, e também quais têm sido seus usos em outros países, especialmente o Canadá, que é um dos países expoentes no assunto e onde realizei meu estágio-sanduíche de onze meses durante o doutorado.

O capítulo está subdividido em quatro tópicos: Contexto; Conceito; Justiça Restaurativa em Outros Cenários e o Caso Canadense; e, finalmente, Revisão Bibliográfica.

\subsection{CONTEXTO}

Boaventura de Sousa Santos (2007) discorre sobre o contexto que teria permitido o surgimento dos modelos alternativos de administração de conflitos. A partir de uma abordagem que trata de um "pluralismo jurídico", conceito que exerceu grande influência para estudos na área, ele aponta como condições: o declínio do Estado-Providência e sua progressiva substituição por formas estatais marcadas por reformas de cunho neoliberal; o aumento de apelos à via judicial, mediante o aparecimento de novas demandas de grupos organizados; e o novo protagonismo do Judiciário.

A atual centralidade do Judiciário, de que fala Santos, se daria por duas razões principais: uma delas diz respeito ao próprio desmantelamento do Estado de Bem-Estar. Este processo resultaria no surgimento de um novo modelo de desenvolvimento mais centrado nas regras de mercado e nos contratos privados, o que implica um Judiciário eficaz, rápido e 
eficiente para que os acordos possam ser cumpridos e os negócios tenham estabilidade. O segundo motivo, por outro lado, diz respeito à precarização dos direitos econômicos e sociais, e a maior conscientização dos cidadãos a respeito disso, o que passa a ser também um motivo de maior procura da população ao sistema de justiça.

Jacques Faget (2006) argumenta ainda que seriam três as correntes de pensamento que favoreceram a disseminação destes novos modelos alternativos de gestão de conflitos: em primeiro lugar a contestação das instituições repressivas - impulsionados pelos trabalhos da Escola de Chicago; em segundo lugar a exaltação do conceito de comunidade, conceito cuja apropriação política visa preencher o vazio deixado pela retirada progressiva do Estado em suas atividades de controle do crime; e em terceiro lugar o movimento de (re) "descoberta" da vítima, resultante da insatisfação desse personagem em relação ao tratamento dado pelo sistema de justiça criminal. Seriam estas algumas importantes transformações que impulsionaram estes modelos alternativos de justiça, dentre eles, a justiça restaurativa.

Tentar-se-á abordar alguns destes pontos, pois são o terreno e a base sobre a qual a discussão a respeito dos meios alternativos de gestão de conflitos e, consequentemente, da justiça restaurativa, emergiu.

Um primeiro ponto diz respeito à questão do acesso à justiça. Assunto trabalhado por autores de áreas tão diversas quanto o teor de suas discussões, ela pode ser analisada a partir de diferentes pontos de referência. Trata-se de um tema caro à sociologia, à política e principalmente ao Direito, do mesmo modo como vem sendo ponto central de discussões envolvendo sociedade civil e poder público.

Marshall (1967), um autor clássico importante no Direito, indicou que o edifício da cidadania moderna está fundamentado sobre a codificação progressiva de direitos civis, político e sociais. Assim, entende-se que a cidadania só poderia ser alcançada se o Judiciário for acessível para garantir a realização dos direitos de todos. Todavia, a articulação de um discurso sobre o incremento dos canais de acesso à justiça como um direito básico a ser assegurado é algo que foi sendo construído historicamente.

No contexto da Inglaterra do século XVIII, quando o homem alcança o status de homem livre e luta pela conquista de seus direitos civis, o acesso à justiça, como bem lembra Cavalcanti (1999), correspondia ao simples direito formal do indivíduo que teve algum direito violado de propor ou contestar uma ação. $\mathrm{O}$ direito à proteção judicial estava atrelado à época a uma dimensão individual.

Foi somente na primeira metade do século $\mathrm{XX}$, e mais especificamente entre as modernas sociedades ocidentais, que o direito ao acesso à justiça passou a ser visto como um 
direito social cuja negação acarretaria a de todos os demais. Essa transformação acontece num momento de criação dos direitos sociais e também de demandas crescentes sobre o Estado. Dessa forma, a expansão do direito ao acesso à justiça, visto agora como um direito fundamental, ocorre juntamente ao processo de implantação do Estado de Bem-Estar social, através do qual se exigia uma intervenção efetiva do Estado no sentido de se garantir os novos direitos que surgiam (id. 1999).

Garapon $(2001 ; 2008)$ constrói uma narrativa de perspectiva histórica que descreve o processo de mudanças pelas quais as esferas do Direito e justiça viriam atravessando, desde o Estado liberal no século XIX, passando pelo Estado provedor, até chegar à sua forma mais atual: o Estado descentralizado. Para o autor, em um primeiro momento prevalecia o Estado liberal cujo objetivo, no âmbito do Direito, era delimitar esferas de atuação na defesa de interesses privados, no qual ele pouco intervinha. Num segundo momento, teríamos tido um Estado provedor no qual a justiça é compelida a proporcionar, não somente de modo formal, mas efetivamente a igualdade de direitos. Esse segundo modelo, de acordo com o autor, apresentaria hoje seu esgotamento, o que abriu portas para o surgimento de um terceiro modelo que traz consigo as práticas de mediação penal ou civil e arbitragens (OLIVEIRA, 2009).

Dessa forma, para Garapon o grande acontecimento dos últimos anos é a descentralização do Estado em diversos níveis que tem como característica o recuo do Estado provedor e um movimento das sociedades ocidentais em direção a um pluralismo social. Santos (2007) é um autor que discute essa questão do pluralismo num nível jurídico, destacando o surgimento de novas formas de justiça como uma abordagem alternativa àquela que focaliza somente a ausência ou ineficácia do direito estatal.

Dentre os estudos clássicos a respeito deste tema do acesso à justiça, destaca-se também o conhecido trabalho de Capelletti e Garth (1998). Como bem lembra Almeida (2012), este trabalho foi importante para a ampliação do significado do direito de acesso à justiça, até então compreendido como apenas acesso aos tribunais. O estudo desses autores foi resultado de uma pesquisa composta de relatos de experiências de diversos países no campo do acesso à justiça. Neste trabalho foram citados alguns países da América Latina e, embora o Brasil não esteja incluído, o argumento dos autores é de que teria havido três ondas que os países adotaram no intuito de superar entraves no acesso à justiça. Elas teriam ocorrido na seguinte ordem: a primeira onda de reformas aconteceu no momento da criação da assistência judiciária gratuita para os mais pobres; a segunda com a representação jurídica dos interesses difusos e a terceira é aquela que propõe um novo enfoque do acesso à justiça; inserem-se, 
nesta etapa, a informalização da justiça e a criação de formas alternativas de administração de conflitos.

O contexto da década de 60, nos países centrais da Europa e Estados Unidos, foi fundamental para o surgimento destas novas alternativas. Esse período, marcado pelo aumento das demandas por parte de movimentos sociais que ganhavam força, acarretou em transformações no Welfare State e nos sistemas de justiça que passaram a ter de lidar com esses novos segmentos.

Ocorre então que o debate em torno das formas estatais e não estatais de administração de conflitos coincide, portanto, com a emergência, a partir da década de 60 , de pressões com vistas à ampliação dos canais de acesso à justiça, no sentido de garantir efetivamente os novos direitos que vinham sendo conquistados por determinadas minorias ou grupos discriminados como: mulheres, negros ou pela sociedade em geral, em relação aos direitos do consumidor e questões ambientais. (CAVALCANTI, 1999)

No Brasil, entretanto, os métodos informais de composição de conflitos, que já vinham sendo empregados em vários países da Europa e Estados Unidos, começaram a ser institucionalizados somente a partir da criação dos Juizados de Pequenas Causas, com o advento da Lei 7.244/84. Esses juizados, que foram criados ainda sob o regime militar, em 1984, no âmbito do Ministério da Desburocratização, tinham por finalidade aumentar o acesso de novas demandas ao Judiciário. Em 1995, com a edição da Lei 9.099/95, retirou-se a expressão "pequenas causas" e ampliou-se a sua competência para a área criminal e, no campo cível, estendeu sua área de atuação para as causas de valor de até 40 salários mínimos. Assim, hoje contamos com os Juizados Especiais Cíveis e Criminais, no âmbito das Justiças Estaduais, disciplinados pela Lei 9.099/95 que regulamentou o dispositivo no Art. 98, inciso I da Constituição da República.

Dispomos hoje também da mediação pré-processual, a partir do momento em que o Conselho Superior da Magistratura, do Tribunal de Justiça de São Paulo, editou o Provimento n. ${ }^{\circ}$ 893/04, alterado parcialmente pelo Provimento n. ${ }^{\circ}$ 953/05, cuja orientação indica a possibilidade de utilização de meios alternativos de administração de conflitos. Autorizou-se, com isso, a criação e instalação de Setores de Mediação ou Conciliação, em todas as comarcas do Estado para questões cíveis que versem sobre: direitos patrimoniais disponíveis, questões de família ou da infância e juventude.

Esta é, contudo, uma iniciativa dos juízes. Cabe a eles a decisão de implantarem ou não este setor em suas comarcas. Assim, mesmo sem lei ordinária que a defina e regulamente 
em âmbito nacional, novos Setores de Mediação Judicial estão sendo implantados em diversas comarcas do Estado de São Paulo ${ }^{11}$.

Em relação à justiça restaurativa, ela não está atualmente regulamentada ou prevista em lei no Brasil. Por essa razão, muitos entrevistados justificam o fato deste modelo alternativo estar hoje no país ligado à justiça juvenil, pois, de acordo com eles, o Estatuto da Criança e do Adolescente (ECA), promulgado em 1990, permite a utilização de procedimentos como os vinculados ao tipo restaurativo. Isso seria possível devido ao teor pedagógico da justiça para infância e juventude e ausência do caráter punitivo comum à justiça para adultos. Uma das razões para isso é que a criança e o adolescente são definidos pelo Estatuto como sujeitos de direitos e ainda em formação, de maneira que intervenções chamadas "socioeducativas" são tidas como as mais adequadas, ainda que diversos autores como Paula (2011) problematizem essas medidas ${ }^{12}$.

O fato é que tais iniciativas, como os Juizados Especiais e os setores de Mediação préprocessual, que têm a finalidade declarada de dinamizar a prestação jurisdicional, no sentido de diminuir a morosidade dos processos e a burocratização na gestão dos mesmos, vêm no bojo das discussões em torno da reforma do Judiciário e relacionam-se ao contexto que permitiu a inauguração de programas inéditos de justiça restaurativa no Brasil.

Nesse sentido, parece que: "No âmbito federal o tema do acesso à justiça é apresentado como uma das prioridades da Reforma do Judiciário. Tal vinculação de temas parece supor que só por meio da Reforma do Judiciário é possível a ampliação do acesso à justiça”. (ALMEIDA, 2012, p. 96)

O capítulo da nossa Constituição sobre o sistema de justiça foi aquele que recebeu o maior número de propostas de revisão. As sugestões de reforma em relação ao Judiciário tramitaram no Congresso Nacional por cerca de uma década e tiveram maior impulso na gestão do presidente Lula (2003-2006; 2007-2010).

Já no início de seu mandato, em maio de 2003, foi criada a Secretaria de Reforma do Judiciário. O então Ministro da Justiça, Marcio Thomaz Bastos, que atuou durante todo o primeiro mandato do presidente Lula e por três meses do segundo, desde as primeiras declarações públicas, já retomava a discussão sobre a reforma do sistema de justiça,

11 O estado de São Paulo possui 644 comarcas e apenas 17,5\% aderiram e implantaram a mediação ou conciliação, posto que a institucionalização de um programa dessa natureza é uma faculdade do juiz (OZORES, 2011).

12 Para uma abordagem histórica da questão, bem como um análise da emergência de discursos que possibilitaram a elaboração de uma legislação de assistência e de proteção aos "menores" no Brasil no início do século XX, consultar ALVAREZ, M. A emergência do Código de Menores de 1927: uma análise do discurso jurídico e institucional da assistência e proteção aos menores. Dissertação de mestrado, USP, 1990. 
reafirmando seu compromisso com a democratização das instituições. O processo de Reforma do Judiciário resultou na aprovação da Emenda Constitucional nº45/2004.

Foi no contexto de criação da Secretaria de Reforma do Judiciário que os três projetospiloto de justiça restaurativa foram inaugurados no Brasil. A então nova Secretaria, responsável pelo financiamento e apoio institucional dos programas, junto com o PNUD (Programa das Nações Unidas para o Desenvolvimento), tinha à época como secretário o advogado Sérgio Renault, que atuou na secretaria durante a gestão de Thomaz Bastos como Ministro da Justiça (2003-2007).

A inauguração dos projetos-piloto segue a linha ideológica e de atuação que a Secretaria da Reforma do Judiciário vinha então seguindo na época. De acordo com um exassessor da secretaria ${ }^{13}$, tão logo assumiu seu posto, Sérgio Renault teria percorrido tribunais de justiça para ouvir o que se tinha a dizer, ouvir reclamações e também sugestões a respeito das instituições e seu funcionamento.

Este entrevistado argumenta que eram duas as preocupações da instituição naquele momento: criar e estabelecer mais meios de pacificação social e tentar diminuir o número de processos. Fica claro que os dois objetivos estão intimamente ligados, já que, como o mesmo afirma, o fato de poder proporcionar a diminuição do número de processos dá mais força política pra esse tipo de proposta de meios alternativos de gestão de conflitos. Este tipo de iniciativa atende a um dos principais requisitos quando se discute a Reforma do Judiciário, que são meios de diminuir a morosidade do sistema de justiça brasileiro.

Em algumas entrevistas, realizadas com atores do Executivo ligados na época à Secretaria, a questão do protagonismo do Poder Judiciário também ficou muito patente.

Sobre este tema destaca-se o estudo que Sadek (2004) realizou junto ao IDESP, que resultou num mapeamento do Judiciário brasileiro. Como descreve a autora, o modelo de presidencialismo consagrado pela Constituição de 1988 deu a esta instituição duas faces: uma de poder de Estado e outra de instituição prestadora de serviço. Assim, o Judiciário pode agir politicamente questionando ou paralisando políticas e atos administrativos aprovados pelos poderes Executivo e Legislativo, ou mesmo determinar medidas independente da vontade expressa do Executivo e maioria parlamentar. Por outro lado, a instituição possui atribuições de um serviço público encarregado da prestação jurisdicional, arbitrando conflitos e garantindo direitos (SADEK, 2004).

\footnotetext{
${ }^{13}$ As entrevistas com atores ligados à Secretaria de Reforma do Judiciário aconteceram durante minha pesquisa de mestrado. Título da Dissertação: Internacionalização do saber jurídico e redes profissionais locais: um estudo sobre justiça restaurativa em São Carlos (SP) e São Caetano do Sul (SP), PPGS, UFScar, 2010.
} 
O sistema presidencialista instituiu, portanto, a separação e independência entre os poderes, mas também incorporou instituições parlamentaristas; fortaleceu o Legislativo, ampliando sua capacidade de fiscalizar e controlar o Executivo e delegou ao Executivo a possibilidade de legislar através das medidas provisórias. Esta situação aumenta as responsabilidades do Judiciário a partir do momento em que ele passa a exercer a mediação política entre os outros dois poderes e, no controle constitucional, dos atos legislativos e de governo (SADEK, 2004). São transformações essas que atingiram um Judiciário despreparado teórica e materialmente para assumir esse novo protagonismo.

A Constituição Federal de 1988 representa, portanto, um marco essencial para o Judiciário e Ministério Público brasileiros, bem como para a discussão acerca do Estado Democrático de Direito. Isto porque com a inclusão dos novos direitos sociais e coletivos e a criação de mecanismos jurídicos para protegê-los, essas instituições do Direito passaram a ter de lidar com conflitos de conteúdos social e político de uma forma não vista anteriormente. Além dos conflitos intersubjetivos de interesses, entram em pauta também questões ligadas ao meio ambiente, à proteção dos direitos do consumidor, de interesses difusos e coletivos (SADEK, 2004; CAVALCANTI, 1999).

Sobre isso, um ex-secretário da Secretaria de Reforma do Judiciário argumenta:

(...) então não é a toa que os principais formuladores dessas alternativas são juízes porque hoje não é mais legislador, não é mais Executivo, hoje é o juiz. O problema da criminalidade está de certa forma batendo na porta do Judiciário, na medida em que o legislador delegou esse Judiciário à cobrança política (...) então você vê hoje as pessoas criticando o Supremo porque o Supremo solta todo mundo, não critica mais a lei porque a lei não é dura o bastante, mas o Judiciário porque aplica mal a lei.

A situação descrita pelo entrevistado remonta ao contexto pós-Segunda Guerra Mundial, quando o Judiciário passou a ser também responsável por evitar abusos do Poder Legislativo. O Judiciário passou a ter, por exemplo, controle de constitucionalidade para afirmar que uma lei não deveria valer porque é inconstitucional. Este tipo de postura, em que o Judiciário pode verificar o que foi produzido pelo Legislativo e barrar, apresenta implicações sobre a atuação dos profissionais. O mesmo entrevistado afirma ainda:

(...) você sai um pouco desse pedestal do aplicador técnico da lei, vem aqui embaixo não porque ele quer, mas porque ele é chamado, a sociedade, a imprensa, o sociólogo, o psicólogo, eles querem saber o que o juiz ta fazendo então ele perde, ele cai da torre de marfim 
porque puxaram ele, trouxeram e aí agora vai ter que dar a resposta como é que ele está decidindo, então isso leva o Judiciário, isso tem um impacto.

Esta figura do juiz que sai de sua torre de marfim é uma imagem que muito apareceu durante o trabalho de campo, especialmente quando a entrevista era realizada com profissionais do Direito detentores de uma visão mais heterodoxa da profissão e envolvidos com onteúdos críticos como é o caso da justiça restaurativa.

Werneck Vianna, Carvalho, Melo e Burgos (1997) já discutiam esse processo de "desneutralização" da figura do juiz. Na medida em que foram introduzidos princípios de justiça na aplicação das normas, espera-se uma atuação do juiz que leve em consideração os efeitos sociais desejáveis ou expectativas de promoção de direitos que se encontram imbuídos nos textos constitucionais. A esse processo denomina-se "judicialização da política" e dele resulta o fato de que agora o Judiciário tem que lidar com questões de ordem legislativa e executiva, com participação na implementação de políticas públicas.

Estes autores também discutem sobre a chamada crise do Poder Judiciário. Para eles a situação de centralidade assumida pelo Judiciário frente aos outros poderes, em que é "chamado" a resolver impasses entre o Executivo e Legislativo, resulta mais de um contexto de transição para a democracia do que vontade própria:

"O que se designa, então, como crise do Poder Judiciário nada mais é do que a sua súbita adaptação à feição contemporânea da sociedade brasileira, sem estar equipado material, conceitual e doutrinariamente para dar conta da carga de novos problemas que a sociedade passou a lhe apresentar". (WERNECK et al, 1997:12).

Por isso, o apelo cada vez maior a esse Poder implica numa sobrecarga que acaba expondo ainda mais suas deficiências, resultantes do fato de não estar preparado para assumir esses novos encargos.

O Corregedor, Desembargador Tasso Caubi Soares Delabary, em reportagem recente a respeito das novas medidas para impulsionar o modelo da justiça restaurativa no estado do Rio Grande do Sul, destacou como isso se relaciona com a atual situação do Poder Judiciário:

Em tempos em que se enfrenta um assoberbamento do Poder Judiciário, com a crescente jurisdicionalização de toda a sorte de conflitos, trazendo constantes desafios para o aprimoramento da prestação jurisdicional frente às limitações orçamentárias e de pessoal, o modelo da Justiça Restaurativa apresenta-se como método alternativo de resolução de conflitos deveras relevante que deve, a 
meu sentir, ser estimulado e aperfeiçoado, com a participação efetiva do Judiciário. Notícia do Tribunal de Justiça do Estado do Rio Grande do $\operatorname{Sul}(21 / 10 / 2014)^{14}$

É neste contexto brasileiro, portanto, de presença de um discurso que ganhou força e que afirma a existência de uma crise no Judiciário que se insere a justiça restaurativa. $\mathrm{O}$ diagnóstico aponta para uma sobrecarga da instituição, situação coexistente com a constatação de que vivenciamos uma judicialização excessiva de conflitos do cotidiano.

Salamanca (2004) é um autor que rebate a ideia de que os métodos informais de mediação de confltios seriam a resposta mais adequada a um quadro de ineficiência da justiça oficial, caracterizada por: incapacidade de atender a demandas crescentes por composições de conflitos, excesso de burocracia e formalismos, altos custos, pouco acessível à maior parte da população, para citar alguns. $\mathrm{O}$ autor acredita que recorrer a essa solução para enfrentar a crise pela qual passa a justiça é o mesmo que desconhecer reais possibilidades que o modelo formal disponibiliza para o enfrentamento dos problemas.

Além disso, diante desse discutível quadro de crise, se a população recorrer a esse tipo de mediação devido à lentidão, altos custos ou outros problemas oriundos do modelo estatal, então, segundo Salamanca, não podemos dizer que houve uma livre escolha pelo método alternativo e sim que os indivíduos foram impelidos a recorrer a ele.

Outra importante contribuição de Sadek (2004) diz respeito ainda à questão do acesso à justiça. A autora problematiza essa noção ao questionar de que acesso se fala tanto. Isso porque estarímos diante de uma situação paradoxal na qual a grande parte dos processos fica concentrada numa pequena parte da população; justamente aquela que consegue angariar mais vantagens de sua utilização, enquanto a maioria desconhece quase por completo o Judiciário, a não ser quando é compelida a procurá-lo por problemas criminais. O que ocorreria, portanto é uma situação incoerente na qual: "poucos procuram muito e muitos procuram pouco":

Tornou-se lugar comum afirmar que sem uma justiça acessível e eficiente coloca-se em risco o Estado de Direito. O que poucos ousam sustentar, completando a primeira afirmação, é que, muitas vezes, é necessário que se qualifique de que acesso se fala. Pois a excessiva facilidade para um certo tipo de litigante ou o estímulo à litigiosidade podem transformar a justiça em uma justiça não apenas seletiva, mas sobretudo inchada. Isto é, repleta de demandas que pouco tem a ver com a garantia de direitos. (SADEK, 2004, p. 45)

${ }^{14}$ Disponível em: http://www.tjrs.jus.br/site/imprensa/noticias/?idNoticia=251596 (acessado dia 23 de outubro de 2014). 
Dessa maneira, segundo a autora, qualquer proposta de reforma do Judiciário deveria levar em conta que o país tem uma justiça muito receptiva a um tipo de litígio e público e pouco atenta às reais demandas de cidadania.

Assim como a justiça restaurativa, existem hoje diversos tipos alternativos de gestão de conflitos "disponíveis" para os cidadãos em litígio acionarem. Diante de uma grande, e provável crescente, demanda aos canais de acesso à justiça, ganha terreno no país a justiça restaurativa concomitante a outras formas de administração de conflitos como: a mediação, a conciliação, a arbitragem, a justiça terapêutica ou comunitária. Dados do PNAD de 2011 mostram que $58 \%$ dos que tiveram conflitos buscou a justiça; $12 \%$ buscou juizado especial e $27 \%$ buscou mediação/conciliação ${ }^{15}$ - são números que expressam uma grande procura da população para resolverem suas contendas através de uma via formalizada.

Porém, é preciso considerar que as diversas opções de meios de administração de conflitos praticadas hoje não são apresentadas igualmente a todos os cidadãos - elas são pensadas para públicos específicos, almejam tratar de conflitos também específicos e atendem a objetivos claros. Essa questão ficará mais clara adiante, quando adentrarmos especificamente nas características dos programas de justiça restaurativa analisados e os círculos que são praticados para atender os conflitos envolvendo crianças, adolescentes e seus familiares.

\subsection{CONCEITO}

Sobre a justiça restaurativa é interessante notar que, enquanto a definimos como um tipo alternativo de administração de conflitos, muitos defensores do modelo dirão que não se trata somente disso, que isto é um reducionismo de algo muito maior, de uma proposta efetiva de mudança de paradigma em nossa sociedade.

Afirmam seus defensores que o diferencial da justiça restaurativa, em relação aos demais tipos alternativos de gestão de conflitos, reside nas premissas que fundamentam sua base teórica. Embora se possa argumentar que a mediação também tem uma fundamentação teórica reconhecida e até mesmo anterior e, portanto, mais sólida que a da justiça restaurativa,

\footnotetext{
15 Dados PNAD (Pesquisa Nacional por Amostra de Domicílios). IBGE - Instituto Brasileiro de Geografia e Estatísitca. Disponível em: www.ibge.gov.br. Acesso em: 10/06/2013
} 
é preciso atentar para o fato de que a justiça restaurativa coloca em questão novos pontos em relação aos tipos “concorrentes".

Contudo, é significativo que, conjuntamente a uma teoria até mesmo bastante sofisticada, é difícil definir a justiça restaurativa em termos mais circunscritos, pois não existe uma definição única para o modelo, ao contrário, o que existe é uma série de valores ao qual ela está ligada e que as práticas deveriam necessariamente contemplar. O termo justiça restaurativa designa, portanto, uma série de procedimentos de composição de conflitos que são conduzidos de maneira diferente tanto em relação ao que o modelo de justiça comum propõe quanto aos demais tipos alternativos de administração de conflitos como a mediação e a conciliação.

Para alguns teóricos do modelo, a falta de um conceito único, "fechado" para a justiça restaurativa resultaria do próprio princípio de informalidade que a fundamenta e, mais ainda, indicam que circunscrevê-la em conceitos pré-definidos iria contra justamente àquilo que ela mesma defende. Outros pensam de maneira contrária e argumentam em favor de uma melhor definição do modelo e de suas práticas. Autores como Froestad, Shearing, (2005) argumentam que se para alguns a justiça restaurativa deveria ser mais precisamente definida, para outros isso desestimularia seu desenvolvimento.

Cabe ressaltar, entretanto, que essa discussão sobre se a justiça restaurativa deveria ou não ser mais bem circunscrita em conceitos pré-definidos não é particular dela, mas diz respeito a todas as formas alternativas de gestão de conflitos. Guillaume-Hofnung (2009) argumenta em favor de uma maior precisão teórica em relação à mediação, já que isso, em sua opinião, incidiria diretamente sobre as práticas, aumentando seu potencial transformador.

De todo modo no caso da justiça restaurativa, a situação se complexifica se lembrarmos que ela engloba sob sua denominação práticas diferentes para a composição dos conflitos. Além dos círculos restaurativos, existem ainda outros tipos como os círculos decisórios, círculos de sentença e a mediação vítima-infrator, para citar alguns. Existem até mesmo divergências entre os entusiastas do modelo, como foi reportado por alguns entrevistados para a pesquisa, em dizer qual formato é melhor. Em geral, os tipos divergem de acordo com o país em que é utilizada, pois existe uma tentativa de adaptação da justiça restaurativa às especificidades da região em que se pretende aplicá-la.

Sobre a variedade de procedimentos ligados à justiça restaurativa, afirma-se que isso só vem a reforçar seu caráter "flexível”, ou seja, isso mostraria a que tipo de valores está ligada. A justiça restaurativa permite práticas diferentes a fim de justamente não estabelecer padrões ou impor a seleção de uma forma sobre outra. Ela estaria aberta a novas 
possibilidades de uso se este se demonstrar melhor e se continuar atrelada aos seus valores fundantes.

Não é objetivo deste trabalho se posicionar em relação a esta discussão defendendo ou não o estabelecimento de um conceito único para o modelo da justiça restaurativa, mas antes mostrar como estas discussões e imprecisões teóricas fazem parte da própria dinâmica do campo que movimenta a justiça restaurativa.

Uma das formas que Howard Zehr encontrou, para driblar a dificuldade de inscrever a justiça restaurativa dentro de um quadro teórico mais "fechado", foi definí-la pelo que ela não é. O autor faz este exercício de definição do modelo em seu livro chamado The little book of restorative justice. Este não é o primeiro livro do autor; seu mais famoso e conhecido livro chama-se Changing lenses e é possível notar entre as duas publicações o movimento do autor de tentar incluir em suas obras posteriores ao primeiro livro as diversas críticas que lhe foram dirigidas.

Esta maneira de definir a justiça restaurativa pelo que ela não é pode ser entendida como uma forma encontrada pelo autor de responder às críticas e mal entendidos que surgiram a partir de seu primeiro livro e com o desenvolvimento da discussão a respeito do tema. Ao mesmo tempo, é importante ressaltar que se trata também de uma maneira legítima de definição, de distinção e portanto, de estabalecimento de fronteiras em relação aos outros tipos de administração de conflitos.

De acordo com Zehr (2012):

\section{A JR não tem como objeto principal o perdão ou a reconciliação;}

Segundo o autor, o perdão e a reconciliação não são obrigatórios e nem o objetivo final de um ritual relacionado à justiça restaurativa, como muitos podem imaginar. Para ele a justiça restaurativa oferece um contexto em que isso pode ocorrer, mas não é obrigatório e fica a cargo das partes. Contudo, é interessante observar que devido a este caráter religioso associado ao modelo (este aspecto especificamente católico, ligado à justiça restaurativa, é bastante nítido em seu livro Changing Lenses) existe até mesmo no Brasil uma corrente de pensamento da justiça restaurativa conhecida por Escola do Perdão e Reconciliação $(\text { ESPERE })^{16}$. Zehr, não menciona em seu livro The little book of restorative justice esta questão.

\footnotetext{
${ }^{16}$ Para ver mais sobre o assunto: Boonen (2011) A justiça restaurativa: um desafio para a educação, Tese da Faculdade de Educação da Universidade de São Paulo.
} 


\section{A JR não é mediação;}

Zehr defende que a justiça restaurativa é mais que a mediação, pois ela não se limita a um encontro. Mais uma vez, vemos aparecer as incertitudes que a falta de uma definição acarreta. Neste caso, a justiça restaurativa é definida como sendo "mais do que um encontro". E mesmo que em um encontro ocorresse mediação, de acordo com o autor, este não seria o melhor termo para definir o procedimento. A justificativa do autor para explicar isso é que em uma mediação presume-se que ambas as partes em conflito atuam em um mesmo nível ético, muitas vezes com responsabilidades partilhadas:

"Embora esse conceito de culpa partilhada seja válido em certos crimes, na maioria deles isso não cocorre. As vítimas de estupro ou mesmo de roubo não querem ser vistas como 'partes de um conflito'. $\mathrm{Na}$ realidade, podem estar em meio a uma luta interna contra a tendência de culparem a si mesmas" ( ZEHR, 2012, p.19)

\section{A JR não tem por objetivo principal reduzir a reincidência ou as ofensas em série;}

Embora não seja o objetivo principal a ser buscado, o autor admite que muitos programas para se promoverem trabalham com categorias como o fator "reincidência". Para Zehr, a diminuição da criminalidade é um subproduto da justiça restaurativa (termo do autor). Aqui no Brasil, é bastante claro como os objetivos dos programas que utilizam este modelo alternativo são os de diminuir a reincidência, bem como evitar o encaminhamento de casos para o Judiciário, como veremos mais adiante.

\section{A JR não é um programa ou projeto específico;}

$\mathrm{O}$ autor admite neste ponto que existem programas com desenhos e propostas muito diferentes promovendo a justiça restaurativa, (para ele alguns programas usam o modelo como um todo, outros apenas em parte) e longe de conseguir resolver a questão de sua definição, utiliza uma metáfora para ilustrar seu argumento: “a justiça restaurativa não é um mapa, mas seus princípios podem ser vistos como uma bússola que aponta na direção desejada" (ZEHR, 2012, p.21) 
A JR não foi concebida para ser aplicada a ofensas comparativamente menores ou ofensores primários;

$\mathrm{O}$ autor argumenta que, embora pareça ser mais fácil angariar apoio da comunidade para programas que atendem casos de menor gravidade, as experiências têm demosntrado que a justiça restaurativa pode ser mais benéfica em casos mais graves. Aqui no Brasil, como indicado anteriormente, o foco ainda são os casos considerados de menor potencial ofensivo que envolvem crianças ou adolescentes, geralmente ofensores primários.

\section{A JR não é algo novo nem se originou nos Estados Unidos;}

Muitos creditam o desenho moderno da justiça restaurativa e sua base teórica ao movimento de comunidades religiosas (notadamente menonitas) dos Estados Unidos e Canadá, na década de 1970, que promoviam programas para o encontro entre vítimas e ofensores. Porém, de acordo com Zehr, a justiça restaurativa deve muito a tradições de povos autóctones norte americanos e da Nova Zelândia (acrescentaria povos africanos também aos que o autor cita, já que uma das metodologias conhecidas no meio e que chegou a ser aplicada no Brasil é o modelo Zwelethemba, de origem sul-africana). Nas palavras do autor: "suas raízes são tão antigas quanto a história da humanidade” (ZEHR, 2012, p.22)

\section{A JR não é uma panaceia nem necessariamente um substituto para o processo} penal;

Neste ponto o autor é categórico: "A justiça restaurativa não é, de modo algum, resposta para todas as situações. Nem está claro que deva substituir o processo penal, mesmo em um mundo ideal” (ZEHR, 2012, p.22)

Zehr endossa a opinião de outros autores, os quais não cita, mas que argumentariam que mesmo se a justiça restaurativa ganhasse ampla implantação, algum tipo de sistema jurídico ocidental ainda deveria existir como meio de salvaguardar os direitos fundamentais. Sua exposição continua no sentido de mostrar que a justiça restaurativa poderia ser complementar à justiça retributiva, pois a primeira (restaurativa) se ocuparia de uma dimensão pessoal relacionada ao crime e à justiça comum caberia se ocupar da dimensão pública do crime (encaixam-se aqui as teorias modernas da pena).

\section{A JR não é necessariamente uma alternativa ao aprisionamento;}

Para o autor as abordagens restaurativas poderiam ser usadas conjuntamente às sentenças de prisão. Sua crítica não é dirigida à prisão em si, enquanto instituição, mas ao uso 
abusivo do aprisionamento por sociedades como a norte-americana ${ }^{17}$. Em sua visão, se a justiça restaurativa fosse utilizada de forma consistente e coerente, o recurso ao aprisionamento seria reduzido.

\section{A JR não se contrapõe necessariamente à justiça retributiva;}

É neste tópico que fica claro o esforço do autor de tentar responder e incorporar em seus trabalhos algumas das críticas que recebeu depois de seus primeiros escritos sobre o tema: "apesar de minhas afirmações em obras anteriores, não vejo mais a justiça restaurativa como oposta à justiça retributiva" (ZEHR, 2012, p.23)

Duas observações são importantes a partir desta última assertiva do autor: a primeira delas é que - como o mesmo deixa claro, a justiça restaurativa não vem sendo pensada como um modelo concorrente, destinado a substituir a forma de pensar e atuar do sistema penal de justiça; o segundo ponto é que esta afirmação do autor relaciona-se diretamente com suas primeiras tentativas de definição de justiça restaurativa, presentes em seu primeiro livro e artigos. Neste primeiro momento, Zehr definia a justiça restaurativa sempre em oposição ao que ele definiu como modelo de justiça retributivo.

Assim, o que pretendo demonstrar aqui, utilizando para isto as obras de Zehr, é que definições de justiça restaurativa que se pautam em uma dicotomia entre dois modelos diferentes de justiça, como sustentado por grande parte dos autores que estão dialogando neste campo, ou a partir do que ela não é, como vimos acima, mais que ajudar no fortalecimento e disseminação do modelo, na verdade limitam sua potencialidade crítica e acabam por reforçar o sistema de justiça criminal com o qual ele compete.

Changing Lenses (1990) é uma obra chave para se compreender a justiça restaurativa. Pode-se dizer, inclusive, que o trabalho do autor na definição do modelo moldou práticas posteriores. Neste livro, Zehr faz uma crítica das formas modernas da justiça criminal já estabelecendo aquilo que vai ser um quase padrão nas bibliografias sobre o tema, um modelo explicativo baseado em uma dicotomia entre os modelos restaurativo e retributivo.

Neste livro, o autor faz uma crítica do modelo comum de justiça argumentando como ele ignora as necessidades dos envolvidos (especialmente as das vítimas) deixando todos os envolvidos insatisfeitos e sugere uma abordagem alternativa, baseada tanto na recuperação de antigas práticas de mediação de populações indígenas, quanto em textos bíblicos.

\footnotetext{
${ }^{17}$ Foucault em Vigiar e Punir (2011) já fez a maior das críticas à prisão.
} 
Autores como Roche (2007) mostram como esse tipo de explicação dualista traz uma série de problemas para avanços no debate e fragiliza ambos os lados, pois desconsidera uma série de pormenores, que ficam de lado. É como se para simplificar e angariar a adesão dos leitores, o autor tivesse que realizar um reducionismo dos dois tipos de justiça que ele classifica.

A seguir, reproduz-se a tabela de Zehr neste livro citado:

Quadro 1: Lentes retributivas e lentes restaurativas

\begin{tabular}{|c|c|}
\hline Lentes retributivas & Lentes restaurativas \\
\hline $\begin{array}{l}\text { Crime definido como violação de regras } \\
\text { (regras violadas) }\end{array}$ & $\begin{array}{l}\text { Crime definido como dano causado a pessoas } \\
\text { e relacionamentos (relações violadas) }\end{array}$ \\
\hline Danos definidos abstratamente & Danos definidos concretamente \\
\hline $\begin{array}{l}\text { Crime visto como categoricamente diferente } \\
\text { de outros danos }\end{array}$ & $\begin{array}{l}\text { Crime reconhecido como relativo a outros } \\
\text { danos e conflitos }\end{array}$ \\
\hline O estado é a vítima & Pessoas e relacionamentos são as vítimas \\
\hline $\begin{array}{l}\text { Estado e ofensor vistos como partes } \\
\text { primárias }\end{array}$ & $\begin{array}{l}\text { Vítima e ofensor vistos como partes } \\
\text { primárias }\end{array}$ \\
\hline $\begin{array}{l}\text { Necessidades e direitos das vítimas } \\
\text { ignorados }\end{array}$ & $\begin{array}{l}\text { Necessidades e direitos das vítimas são } \\
\text { centrais }\end{array}$ \\
\hline Dimensões interpessoais irrelevantes & Dimensões interpessoais centrais \\
\hline Natureza conflitiva do crime obscurecida & Natureza conflitiva do crime reconhecida \\
\hline Feridas do ofensor periféricas & Feridas do ofensor importantes \\
\hline Ofensa definida termos técnicos e legais & $\begin{array}{l}\text { Ofensa entendida em seu contexto: moral, } \\
\text { soial, econômico e político }\end{array}$ \\
\hline
\end{tabular}

Fonte: Zehr, Changing Lenses (1990: 184-5) *Tradução livre da autora

Quando o livro foi publicado, em 1990, a justiça restaurativa ainda estava dando seus primeiros passos. Já havia esforços para reformar os sistemas de justiça criminal em diversos países como EUA, Inglaterra e Nova Zelândia, o que deu mais voz para aqueles diretamente afetados pelos crimes como vítimas, familiares e ofensores, que passaram a poder se expressar mais, mas esses programas funcionavam ocasionalmente e isolados uns dos outros. Mais importante ainda, faltava um forte quadro teórico para sustentar essas iniciativas. Isso mudou drasticamente ao longo da década de 90 quando agentes públicos, comunidades e acadêmicos 
começaram a visitar e comparar estes novos programas e escritores como Zehr começaram a alocar estas ideias em um contexto histórico e teórico (ROCHE, 2007).

Cada vez mais pessoas começaram a se referir a este novo modelo; a adoção do título não foi imediata, como é possível observar nos trabalhos de Braithwaite e Mugfor de 1994 e Zedner (mesmo ano). Estes autores ainda não usavam o termo justiça restaurativa. Mas a partir da segunda metade da década a expressão foi ganhando cada vez mais popularidade. Roche (2007) argumenta que em 2006 o termo passa a ser quase que universalmente utilizado, lembrando que, no Brasil, os programas de justiça restaurativa começaram a funcionar em 2005.

Junto com o desenvolvimento do termo, na mesma esteira vieram as dicotomias entre os dois modelos de justiças, como Zehr propôs. Aqui no Brasil essa definição da justiça restaurativa, em oposição ao modelo de justiça comum, também ressoou. Um exemplo que mostra a adoção desta oposição entre os dois tipos são as tabelas que se encontram no livro sobre o programa de justiça restaurativa de São Caetano do Sul, organizado pelos seus próprios fundadores e profissionais atuantes, chamado Justiça Restaurativa e Comunitária em São Caetano do Sul: aprendendo com os conflitos a respeitar direitos e promover cidadania (2008).

É muito comum nos livros que abordam o tema da justiça restaurativa, ou mesmo em eventos que se propõem a divulgá-la, serem utilizados estes tipos de quadros ou tabelas, a fim de que visualmente fiquem bem claras as diferenças entre os modelos alternativo e retributivo: 
Quadro 2 - Entendimentos do crime

\begin{tabular}{|c|c|}
\hline Justiça Tradicional & Justiça Restaurativa \\
\hline Crime definido como violação de regra & Crime definido pelo dano às pessoas e às relações \\
\hline Dano definido abstratamente & Dano definido concretamente \\
\hline Crime visto como categoricamente diferente de & Crime reconhecido como relacionado a outros \\
\hline outros danos & danos e conflitos \\
\hline Estado como vítima & Pessoas e relações como vítimas \\
\hline Estado e ofensor vistos como partes primárias & Vítima e ofensor vistos como partes primárias \\
\hline Necessidades e direitos das vítimas ignorados & Necessidades e direitos das vítimas como centrais \\
\hline Dimensões interpessoais irrelevantes & Dimensões interpessoais como centrais \\
\hline Natureza conflitual do crime obscurecida & Reconhecida a natureza conflitual do crime \\
\hline Feridles do ofen cor neriféricos & Feridas do ofensor importantes \\
\hline Ofensa definida em termos técnico-jurídicos. & $\begin{array}{l}\text { Ofensa entendida em seu amplo contexto: } \\
\text { moral,social, econômico e político. }\end{array}$ \\
\hline
\end{tabular}

Fonte: Justiça Restaurativa e Comunitária em São Caetano do Sul: aprendendo com os conflitos a respeitar direitos e promover cidadania (2008) 
Quadro 3 - Entendimentos de justiça

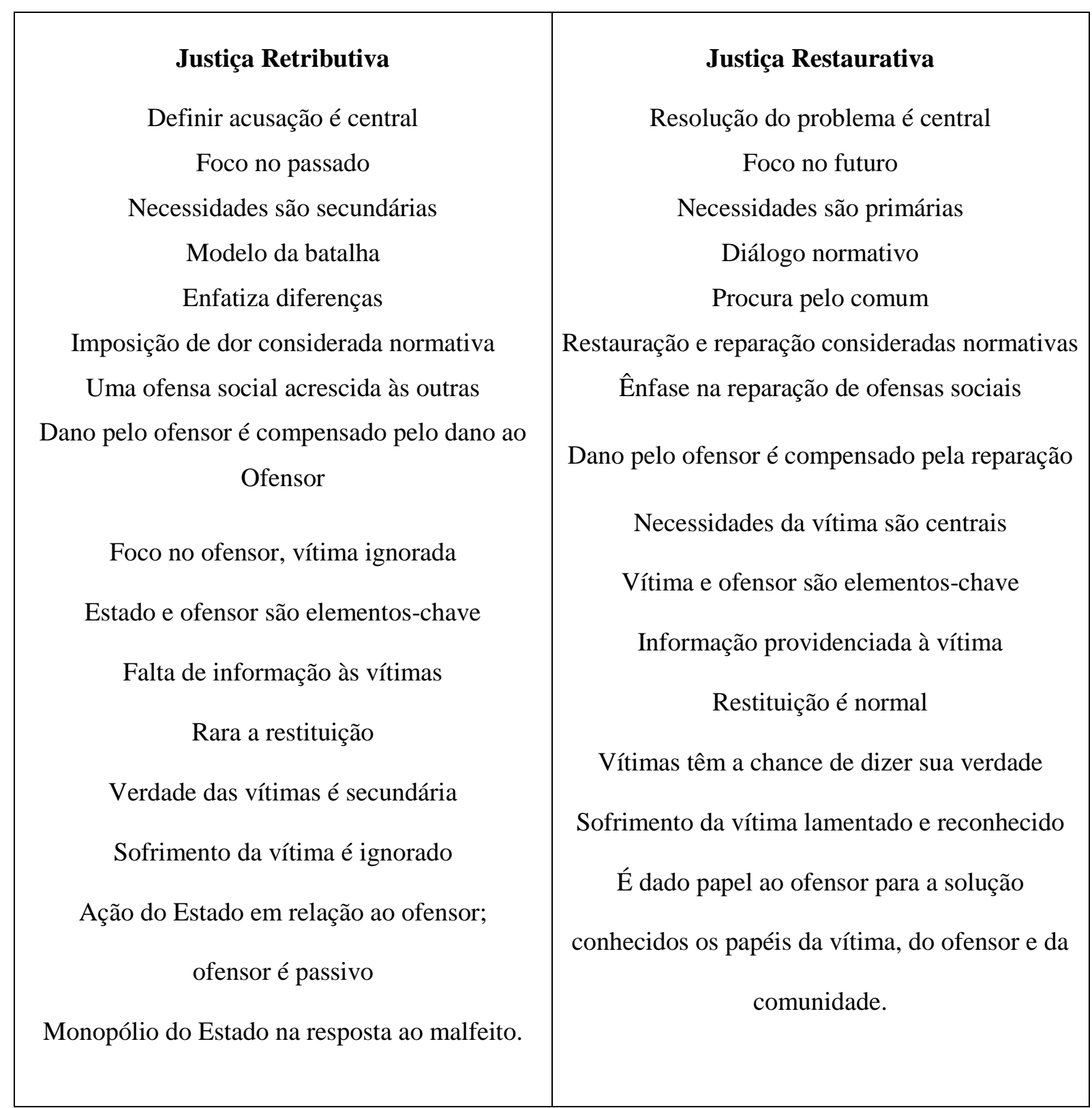

Fonte: Justiça Restaurativa e Comunitária em São Caetano do Sul: aprendendo com os conflitos a respeitar direitos e promover cidadania (2008) 
Quadro 4 - Entendimentos de responsabilidade

\begin{tabular}{|c|c|}
\hline Justiça Tradicional & Justiça Restaurativa \\
\hline Erro cria culpa & Erro cria dúvidas e obrigações \\
\hline Culpa é absoluta (sim/não) & Graus de responsabilidade diferenciados \\
\hline Culpa é indelével & $\begin{array}{l}\text { Culpa é removível através de arrependimento e } \\
\text { reparação }\end{array}$ \\
\hline Dívida é abstrata & Dívida é concreta \\
\hline Débito pago pelo recebimento da punição & Débito pago pela ação reparadora \\
\hline Dívida devida à sociedade abstratamente & Débito devido primeiramente à vítima \\
\hline Responsabilidade como tomada de remédio & Prestação de contas como responsabilidade \\
\hline Assunção do comportamento escolhido livremente & $\begin{array}{c}\text { Reconhece a diferença entre realização potencial e } \\
\text { atual da liberdade humana }\end{array}$ \\
\hline Livre-arbítrio ou determinismo social & $\begin{array}{l}\text { Reconhece o papel do contexto social como } \\
\text { escolha, sem negar a responsabilidade pessoal. }\end{array}$ \\
\hline
\end{tabular}

Fonte: Justiça Restaurativa e Comunitária em São Caetano do Sul: aprendendo com os conflitos a respeitar direitos e promover cidadania (2008)

Matthews (2006) é outro autor que também critica esta dicotomia que alguns defensores da justiça restaurativa como Zehr e Braithwaite fizeram entre justiça restaurativa e justiça retributiva. Para este autor a questão do formalismo e informalismo não é uma opção por um ou outra, mas uma questão de gradação:

"Esta dicotomia irreal não somente negligencia as formas pelas quais a justiça restaurativa pode ser mais punitiva que processos judiciais, mas também (negligencia) como estratégias restaurativas, reparativas e compensatórias são características recorrentes do sistema de justiça criminal existente" 18 (MATTHEWS, 2006: 250).

$\mathrm{Na}$ esteira do argumento de Matthews, Duff também argumenta em seu artigo chamado "Restorative punishment and punitive restoration" (2006) que nossas respostas para os crimes deveriam buscar a restauração, ou a justiça restaurativa, mas o tipo de restauração que o malfeito criminal pede, na opinião do autor, só poderia ser totalmente alcançado através de um processo de punição retributiva. Duff acredita ter resolvido a discussão entre os

\footnotetext{
${ }^{18}$ Tradução livre da autora. No original: "This unrealistic dichotomy not only overlooks the ways in which restorative justice can be more punitive than court processes but also how restorative, reparative and compensatory strategies are a regular feature of the existing criminal justice system".
} 
defendores e os opositores da justiça restaurativa através de seu argumento, que nada mais faz que confundir, através de um jogo de palavras, as diferentes propostas entre o modelo de justiça criminal e a justiça restaurativa, principalmente no que se referem à punição.

Dessa forma, é possível observar como este tipo de definição abre margem para uma série de críticas direcionadas ao modelo restaurativo, o que foi algo que efetivamente aconteceu após a publicação da obra de Zehr, tirando do foco as reais inovações que a justiça restaurativa traz, como a recuperação do papel da vítima a partir de processos decisórios mais inclusivos e a reparação e a responsabilização como resposta ao conflito, no lugar da punição como convencionalmente utilizada pelo sistema de justiça criminal.

Entretanto, a despeito destas discussões em torno das possíveis definições para a justiça restaurativa, para fins analíticos faz-se necessário traçar em algumas linhas em que consiste este modelo alternativo de composição de conflitos. É preciso em alguma medida definí-lo para que possamos compreeender qual é a sua orientação e o que vem sendo realizado na prática.

Assim, é possível afirmar que a justiça restaurativa é, fundamentalmente, a proposta de um modelo alternativo de administração de conflitos, que tem por fim último restaurar as relações que foram prejudicadas pela emergência de um conflito. Reside neste objetivo da justiça restaurativa a principal tentativa de ruptura com o modelo de justiça comum, que se centra sobre o ato da quebra da lei praticado pelo ofensor.

Essa é considerada sua grande novidade, porque justamente tenta promover um deslocamento do foco da justiça criminal para o dano causado à vítima e também à comunidade. Grosso modo, o importante seria restaurar e não simplesmente punir.

Para atingir sua finalidade, este modelo alternativo propõe formas mais consensuais de composição dos conflitos, com participação mais ativa da vítima, ofensor e comunidade, num processo que pode ser conduzido por um membro treinado da comunidade, ou seja, uma pessoa sem formação no Direito (MELO, 2005; GOMES PINTO, 2005, PALLAMOLLA, 2009).

Para ser posta em prática, a justiça restaurativa pode se utilizar de diversos tipos de processos que a compõem. Há, para citar alguns: a mediação vítima-infrator, a conferência, os círculos de pacificação, os círculos decisórios e a restituição; mas, aqui no Brasil, o círculo restaurativo tem sido mais extensamente utilizado. Cabe já destacar que, além de entrevistas com profissionais e participação em workshops e eventos, foram os círculos restaurativos assistidos o principal objeto sobre o qual o texto se debruçará mais adiante. 
No Brasil, o foco da justiça restaurativa tem sido os adolescentes em conflito com a lei, especialmente casos que aconteceram em escolas, mas em outros países casos mais graves chegam a ser atendidos. Ela vem sendo utilizada na Nova Zelândia, Canadá, África do Sul, Estados Unidos, entre outros países. A literatura a respeito do tema indica que a Nova Zelândia figura possivelmente como um dos lugares mais avançados no que diz respeito à sua utilização (ZEHR, 2008). Neste país, a justiça restaurativa se constituiu em uma forma de tentar recuperar formas de gestão de conflitos de populações nativas, que não se viam representadas nas formas oficiais e que não compartilhavam dos mesmos símbolos ou rituais. Hoje ela está contemplada na Carta Constitucional do país.

Este tipo de justiça promove, portanto, o resgate de algumas práticas originalmente indígenas, consolidadas através de séculos. Uma dessas práticas diz respeito à formação de círculos decisórios em que, membros da comunidade se reúnem a fim de discutirem os problemas em questão e os pontos que convergem para as possíveis soluções.

Mas a justiça restaurativa não propõe somente uma recuperação de formas tradicionais de composição de conflitos, como se pode deduzir do caso neozelandês. Mais que isso, ela está fundamentada sobre uma base teórica que privilegia no processo o protagonismo das partes em conflito, em detrimento de um terceiro cujo papel atribuído seria o de decisão; e abre ainda a possibilidade de uma solução negociada entre os próprios envolvidos, com participação mais ativa da vítima, ofensor, comunidade, família ou de mais pessoas envolvidas na contenda (PALLAMOLLA, 2009).

O principal objetivo da justiça restaurativa, contrariamente ao sistema de justiça corrente, que se apoia no retributivismo e punição, é reparar as relações que foram atingidas pelo conflito. A reparação se estende, neste caso, para além das duas partes em disputa, podendo incluir também familiares, amigos, vizinhança e até mesmo a comunidade que possa ter sido afetada de alguma forma. A justiça restaurativa estaria mais preocupada, portanto, com os efeitos que restaram do incidente; por isso presta maior atenção aos danos que a vítima sofreu e que atingiram também a comunidade, ao mesmo tempo em que fomenta maior responsabilização do ofensor sobre sua atitude.

Cabe ressaltar, também, que o ressarcimento nem sempre é material, ele pode ser moral, por exemplo, a depender do consenso entre as partes. Sinteticamente, pode-se dizer, então, que o modelo restaurativo pretende basicamente conciliar os interesses e expectativas de todos os envolvidos no problema criminal, através da pacificação da relação social conflituosa que o originou. (DE VITTO, 2005). 
Durante o procedimento, as vítimas e os contraventores são convidados a negociar formas de reparação, e a comunidade envolvida pode tomar parte ativa no processo (PALLAMOLLA, 2009). Assim, é possível deduzir que, ao contrário do modelo de justiça comum, a vítima passa a ter um papel mais ativo no processo e não apenas a de fornecedora de provas.

Além disso, defensores deste modelo alternativo argumentam que ao focar nos efeitos remanescentes do conflito, a justiça restaurativa estaria se preocupando com o futuro, diferentemente do nosso modelo de justiça comum que se centra sobre o passado. A ideia difundida aqui é a de que todo o nosso sistema se baseia numa sucessão de imposições de sofrimento, pois o cárcere estabeleceu-se como punição infligida de acordo com o dano causado à vítima (MELO, 2005; SICA, 2007) que nunca poderia ser totalmente restaurado desta forma.

Desse modo, se o modelo formal se coloca como um tipo de justiça que se prende ao passado, a algo que aconteceu e não poderia ser totalmente recuperado, a justiça restaurativa, diferentemente, se preocuparia com o futuro, já que seu foco não é a punição, mas a restituição do tecido social rompido (MELO, 2005).

Ademais, a justiça restaurativa poderia ser entendida ainda como uma crítica dirigida ao modelo de justiça comum, já que propõe uma abordagem mais humana da justiça, afastada dos ritos e intervenções hierárquicas presentes nos procedimentos mais formais.

Cappelletti e Garth (1998) mostram como muitas das características do sistema estatal de justiça que o torna habilitado para resolver questões de direito público ao mesmo tempo também o torna pouco adequado para fazer valer os direitos num nível mais individual. Essas características se constituem enquanto alvo de severas críticas por parte daqueles que se identificam como integrantes de um movimento crítico, dos defensores de uma reforma nas estruturas do Judiciário, ou mesmo profissionais detentores de uma visão mais pluralista. Essas características, que consistem basicamente em rituais altamente estruturados, dispendiosos e contando com a participação de profissionais especializados podem ser essenciais para a defesa de interesses difusos, mas, segundo os autores, impõem severas restrições no acesso a pequenas causas intentadas por pessoas comuns.

A justiça restaurativa faz parte, portanto, de uma vertente do Direito que vem chamando atenção e que apóia métodos alternativos de solução de disputas; uma proposta que diverge dos rituais comuns ao sistema de justiça criminal, que estabelece uma intervenção hierarquizada dos participantes, ao mesmo tempo em que delega à vítima um papel passivo no processo, apenas como fornecedora de provas. Ao menos, isso é o que nos diz o arcabouço 
teórico que sustenta o modelo e como constantemente reforçado pelos seus defensores. Veremos ao longo do texto, entretanto, como, na prática, as fronteiras que separam as diferentes formas de administração de conflitos se confundem.

Sobre o procedimento da justiça restaurativa em si, é possível afirmar que, em grande parte das vezes, ele é realizado na forma de um círculo, são os chamados círculos restaurativos, já citados anteriormente. $\mathrm{O}$ fato de a intervenção acontecer a partir de uma disposição que coloca todos os presentes em mesma posição já se configura numa tentativa de romper com as hierarquias presentes nos demais rituais judiciários. Ali o infrator, mais um mediador, que pode ser um membro treinado da comunidade, a vítima e às vezes mais pessoas da família ou comunidade, participam ativa e coletivamente na construção de soluções para o problema (GOMES PINTO, 2005).

Também como forma de se diferenciar do tipo de resolução oficial, termos convencionalmente utilizados como "vítima", "réu", “infrator", “ofensor" 19 não são mobilizados para que os participantes não se sintam envolvidos em um processo estigmatizante. Dessa maneira, a justiça restaurativa, levando em conta o contexto em que se produziu o ato conflituoso, teria se apercebido do fato que nesse campo tudo seria muito relativo - a vítima às vezes também é réu e vice-e-versa - é comum, nesse caso, os papéis se inverterem no cotidiano das relações.

É necessário ressaltar também que todos os envolvidos queiram voluntariamente participar e isso já estabeleceria um tipo de compromisso diferenciado (CARVALHO, 2005).

A partir desta descrição dos contornos básicos da justiça restaurativa, podemos agora estabelecer alguns dos principais valores e princípios que ela apregoa. É neste terreno dos valores e princípios que os autores parecem convergir mais.

Zehr (2008) argumenta que existem três pilares na justiça restaurativa: danos e necessidades; obrigações e engajamento.

\footnotetext{
${ }^{19}$ Cf. FOUCAULT, Michel. Os anormais. São Paulo: Martins Fontes, 2001. 480p.
} 


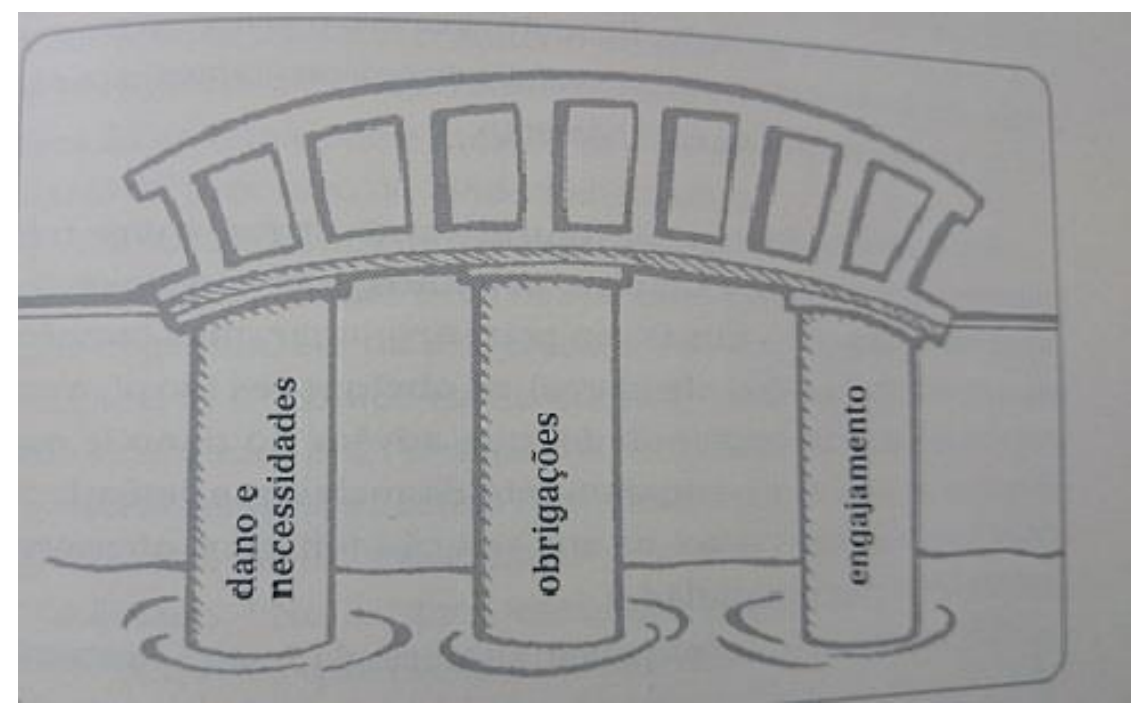

Ilustração1: Pilares da justiça restaurativa. Fonte: Zehr, H. Justiça Restaurativa. São Paulo: Palas Athena, 2012.

O primeiro aspecto, que são os danos e as necessidades, configura-se em uma tentativa de recuperar a noção de que o dano envolve pessoas. $\mathrm{O}$ autor defende que nosso sistema jurídico perdeu esta noção de vista quando o Estado assumiu o lugar da vítima no conflito, que passa a ser figura secundária no processo. No sistema de justiça comum este personagem não tem voz nem suas necessidades são comtempladas. A justiça restaurativa, de maneira contrária, tenta acomodar não só as necessidades da vítima no processo, como também as do próprio ofensor e da comunidade.

Isto leva ao segundo ponto que são as obrigações. Dessa forma, para que o ritual alternativo tenha prosseguimento é necessário que o ofensor se responsabilize pelo ato cometido. Se esta responsabilização no sistema de justiça corrente significa a punição do autor pelo ato delituoso, na justiça restaurativa, diferentementre, ela deriva do comprometimento do autor na tentativa de reparação dos danos.

O último pilar constitui-se no engajamento, que deriva do fato de a justiça restaurativa privilegiar formas mais consensuais, participativas e inclusivas de administração do conflito, em um espaço em que todos se sintam encorajados a dialogarem.

Zehr também afirma serem cinco os princípios da justiça restaurativa:

1. Foco nos danos e consequentes necessidades dos envolvidos (vítima, ofensor, comunidade);

2. Tratar das obrigações que resultaram do ato lesivo;

3. Utilização de processos cooperativos, inclusivos;

4. Envolvimento de todos que estão imbricados na situação; 
5. Correção dos males;

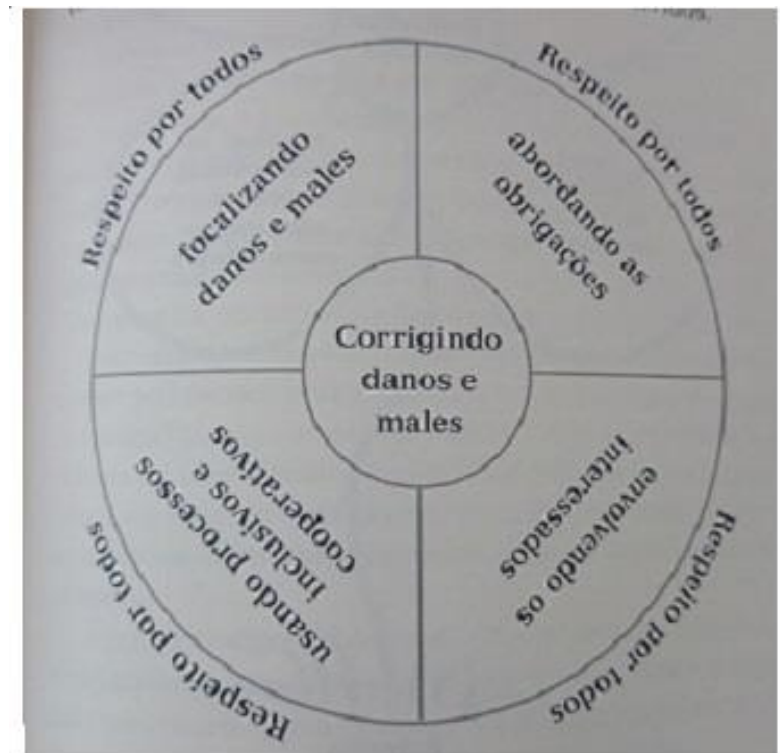

Ilustração 2: Princípios da justiça restaurativa. Fonte: Zehr, H. Justiça Restaurativa. São Paulo: Palas Athena, 2012.

Zehr (2012) também utiliza uma imagem mais orgânica (expressão do próprio autor) para ilustrar seu argumento: 


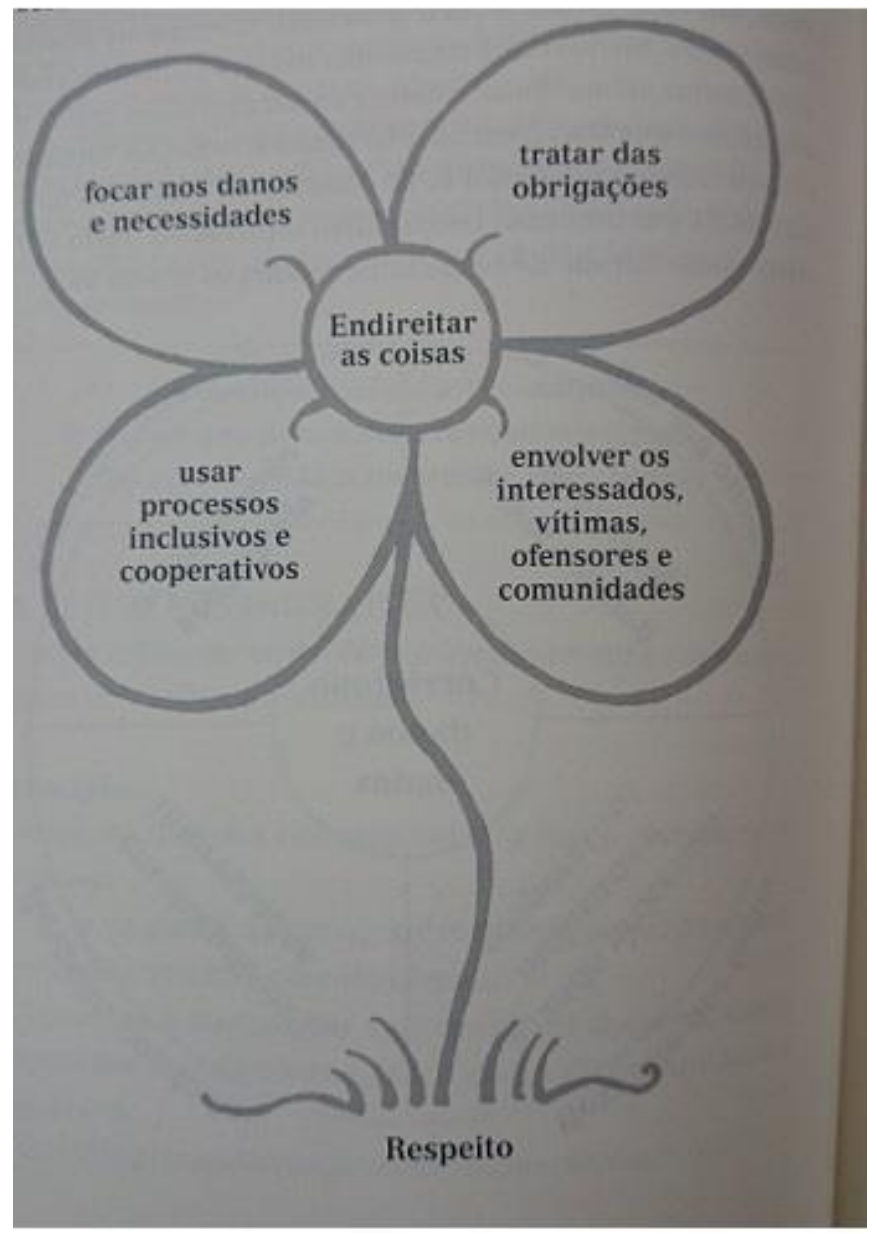

Ilustração 3: Flor da justiça restaurativa. Fonte: Zehr, H. Justiça Restaurativa. São Paulo: Palas Athena, 2012.

Em suas palavras: "Para que funcionem adequadamente, os princípios da Justiça Restaurativa (o centro e os raios) devem ser cercados por um cinturão de valores. Para que floresçam, os princípios que constituem a flor da Justiça Restaurativa devem estar enraizados em certos valores." (ZEHR, 2012, p.47)

O primeiro valor citado pelo autor é o da interconexão: "Estamos todos ligados uns aos outros e ao mundo em geral através de uma teia de relacionamentos. Quando esta teia se rompe, todos são afetados.” (Id., 2012, p.47). Ao mesmo tempo, segundo ao ator, há que se lembrar que todos somos diferentes também e é preciso que a justiça restaurativa respeite a individualidade de cada um bem como os contextos e situações específicas com as quais está lidando.

O autor também não limita os valores inerentes à justiça restaurativa, diz que ela nos incentiva a continuar explorando outros valores, mas frisa que talvez o principal, dentre todos eles seja o respeito. É ele que deve orientar todo o processo de gestão do conflito e deve estar refletido igualmente em seus resultados. 
Nesse sentido, algumas das ideias e propostas da justiça restaurativa se aproximam muito da chamada "resposta circular", como já definia já Mary Parker Follett na década de 1930:

"O pensamento mais fundamental em tudo isso é que a reação é sempre reação à uma relação (...) Eu nunca reajo a você, mas à vocêmais-eu; ou, para ser mais preciso, sou eu-mais-você reagindo a vocêmais-eu. 'Eu' nunca posso influenciar 'você' porque você já me influenciou; ou seja, no próprio processo do encontro, pelo próprio processo de encontro, que ambos nos tornamos algo diferente. Isto começa antes mesmo de nos encontrarmos, na antecipação do

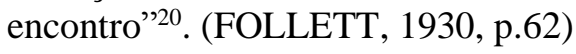

Embora a autora estivesse dialogando mais no campo da psicologia (a autora pretendia através de seu conceito de resposta circular contribuir no debate que havia então entre o objetivismo e o subjetivismo) seus achados parecem se encaixar dentro das características que os defensores do modelo restaurativo propagam.

Uma das consequências de a justiça restaurativa se basear mais em valores e princípios que em definições mais circunscritas, é que autores como Zehr acabaram estabelecendo um continuum para fins de medir se um programa é restaurativo ou não, o que pode ser considerado meio muito amplo e controverso de medir as práticas:

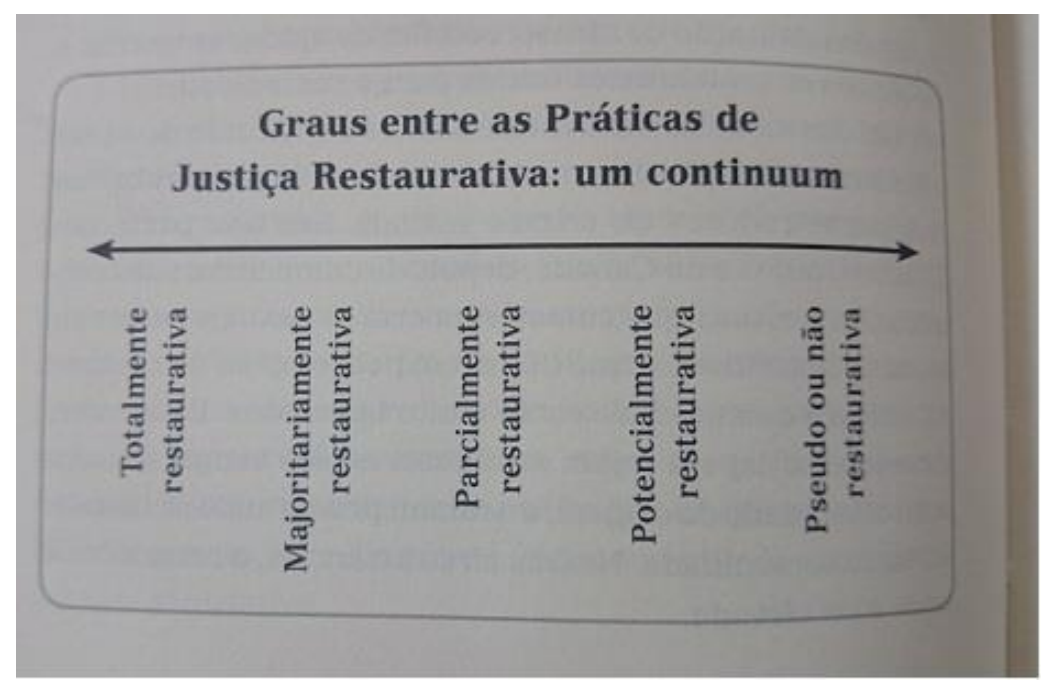

Ilustração 4: Graus de justiça restaurativa. Fonte: Zehr, H. Justiça Restaurativa. São Paulo: Palas Athena, 2012.

\footnotetext{
${ }^{20}$ Tradução livre da autora. No original: "The most fundamental thought about all this is that reaction is always reaction to a relating (...) I never react to you but to you-plus-me; or to be more accurate, it is I-plus-you reacting to you-plus-me. 'I' can never influence 'you' because you have already influenced me; that is, in the very process of meeting, by the very process of meeting, we both become something different. It begins even before we meet, in the anticipation of meeting".
} 
Vimos até o momento os pontos nos quais parece haver uma aproximação dos teóricos da justiça restaurativa em relação a sua constituição conceitual. O maior consenso entre os autores reside nos valores e princípios que a justiça restaurativa defende.

Neste momento do texto, cabe também apontar algumas das divergências entre os autores ou mesmo entre os envolvidos na aplicação do modelo. Diferentemente de Zehr, Jaccoud (2007) argumenta que a origem do termo restaurativo viria muito mais de uma transformação da justiça terapêutica do que em oposição ao modelo retributivo, como alguns autores argumentam. Ela diz que a expressão justiça restaurativa ganhou corpo dentro de uma ótica de reforma do modelo terapêutico e não, como geralmente se pensa, a partir de uma contestação exclusiva do modelo de justiça punitivo.

A autora também afirma que transpor o crime para dentro de um registro de ruptura de um laço social, como a teoria da justiça restaurativa faz, coloca diversos problemas. Ela sustenta que o crime não perde sua característica transgressiva, ele só é transferido de um registro jurídico a um registro social: "Uma legitimidade quase inabalável de um direito à reparação por um lado e de um dever de reparar do outro lado vem a reintroduzir um desequilíbrio entre as partes que os fundadores do modelo tentaram diminuir"21 (JACCOUD, 2007, p.6).

Além desta observação crítica, o argumento principal de Jaccoud em seu artigo é a apresentação de três modelos de justiça restaurativa. Dessa forma, a autora não se restringe somente à crítica, ela efetivamente propõe uma conceituação no qual seria possível destacar três modelos diferentes de justiça restaurativa que ela identificou:

1. Um modelo centrado sobre as finalidades;

2. Um modelo centrado no processo;

3. Um modelo centrado nas finalidades e nos processos negociados;

No primeiro fica claro como o foco reside nos resultados da intervenção, que devem seguir os princípios e valores restaurativos, não sendo essencial, portanto, que os meios através dos quais os resultados foram alcançados sejam considerados restaurativos.

\footnotetext{
${ }^{21}$ Tradução livre da autora. No original: «Une légitimité quasi inébranlable d'un droit à la réparation d’une part et celle d'un devoir de réparer d'autre part viennent réintroduire le déséquilibre entre les parties que les fondateurs du modèle tentaient pourtant d'amenuiser ».
} 
No segundo modelo, que se centra sobre o processo, o resultado pode ser até punitivo desde que o processo de decisão tenha contado com a participação dos envolvidos. A autora entretanto, faz a crítica, bastante pertinente, inclusive para pensarmos o caso brasileiro:

\begin{abstract}
A participação cidadã e comunitária não é nada indicativa de qualquer mudança paradigmática em relação ao modelo punitivo. Ela participa mais de uma tentativa de reconstrução de uma legitimidade estatal cada vez mais fragilizada no campo sócio-penal e para gerar a ordem pública dentro de uma lógica de eficiência e de racionalização dos gastos públicos ${ }^{22}$. (JACCOUD, 2007, p.7)
\end{abstract}

O terceiro modelo, que reune os dois, meios e resultados, defende o princípio segundo a qual a participação do Estado compromete os fundamentos do modelo. Seria necessário por isso designar à justiça restaurativa uma função exclusiva de alternativa ao sistema penal ficando sua aplicação condicionada aos espaços nos quais não haja a interferência do Estado.

Pallamolla (2009) identifica ainda duas tendências entre os defensores do modelo restaurativo: uma maximalista, que defende a justiça restaurativa inserida no sistema de justiça criminal, que se preocupa com os resultados restaurativos e aceita que a reparação da vítima seja imposta ao ofensor; e outra minimalista, que opta por manter a justiça restaurativa afastada do sistema criminal, pois acredita que assim é possível mudá-lo sem, contudo, aderir à lógica punitiva do sistema; estes também primam pelos processos restaurativos mais que pelos seus possíveis resultados.

Existe também todo um debate em torno dos formatos diferenciados de aplicação do modelo. Existem até mesmo divergências entre os entusiastas do modelo, como foi reportado pelos entrevistados para a pesquisa, em dizer qual formato é melhor. Só para ilustrar este fato, aqui no Brasil foram duas as principais referências que ampararam a criação dos programaspiloto de justiça restaurativa: os modelos da Comunicação Não Violenta (CNV) e o Zwelethemba (originário da África do Sul).

Hoje, em nosso país, o campo em torno deste modelo informal de administração de conflitos conta com diversos grupos que realizam capacitações para os profissionais que vão lidar com o tema. Como veremos mais adiante na tese, estes grupos, que se especializaram em determinadas metodologias (CNV, Zwelethemba, ESPERE), concorrenciam entre si e disputam os espaços nos quais a justiça restaurativa se apresenta como oportunidade.

\footnotetext{
${ }^{22}$ Tradução livre da autora. No original: "La participation citoyenne et communautaire n'est en rien indicative de quelque changement paradigmatique que ce soit par rapport au modèle punitif. Elle participe plutôt d'une tentative de reconstruire une légitimité étatique de plus en plus fragilisée dans le champ sociopénal et celle de gérer l'ordre public dans une logique d'efficience et de rationalisation des dépenses publiques".
} 
Finalmente, existe ainda uma outra discordância entre os autores que discutem o modelo de justiça restaurativa. Já vimos como existem diferentes concepções sobre este tipo de justiça (embora seja possível delineá-lo a partir de alguns pontos nos quais os autores se aproximam). Mas cabe ressaltar que a própria noção de conflito em que os autores se baseiam também diverge. É possível perceber entre os trabalhos diferentes concepções que os autores sustentam sobre o que é o conflito e como ele deve ser abordado.

Para Zehr (2012), o conflito se configura enquanto um "comportamento socialmente nocivo" (em suas palavras) ou, mais ainda, segue afirmando que "o comportamento socialmente nocivo é, via de regra, sintoma de que algo está fora de equilíbrio nessa teia”. Além do mais, de acordo com o autor, caberia então à justiça restaurativa "endireitar as coisas", na expressão utilizada por ele.

É possível inferir que este autor detém uma visão bastante funcionalista acerca da sociedade, entendida aqui como uma "teia" que deveria ser em sua essência harmônica. Ou seja, de acordo com a ideia defendida pelo autor, o conflito emerge como uma dissonância, um sinal de que algo está fora do lugar e que seria preciso então "endireitar" as coisas para que elas retornem a um estado anterior de paz.

Muitos provavelmente diriam que este autor se ampara em uma visão idealizada sobre o que é a sociedade, mas seria preciso antes analisar em que medida estas afirmações não fazem mais que corroborar a tese que pretende defender em seus textos.

Essa noção funcionalista acerca do modo de funcionamento da sociedade coaduna com as concepções propagadas pelas teorias da justiça restaurativa. Como vimos anteriormente, este modelo altenativo de gestão de conflitos parte da ideia de que é preciso restaurar as relações que sofreram com o conflito. Autores como Nader (1994) incluem essas iniciativas dentro do que a autora denomina como ideologias da harmonia.

De maneira diferente, o entendimento que Salm e Leal (2012) manifestam em seu artigo é o de que o conflito comporta uma dimensão positiva. Ele não é aqui entendido como uma anormalidade nas relações que deva ser corrigida, ao contrário, ele seria constituinte das relações humanas, e não só pode, como deveria, ser encarado como uma oportunidade criativa (termos utilizados pelo autor). Segue o excerto em que eles discorrem sobre a questão:

"O conflito como uma oportunidade criativa: é neste momento que argumentam os autores acerca da possibilidade de integração e aprendizagem com a dessemelhança, não havendo a intencionalidade de acabar com o conflito (o que já se tornou 
pacífico nos estudos criminológicos), já que são inerentes à estrutura social, sendo uma questão crucial o modo como se vai trabalhar e encarar estes conflitos e estas dessemelhanças, que podem ser elementos de inter-relação calcados na aprendizagem mútua". (SALM, LEAL, 2012, p. 208)

Ficam evidentes como as duas perspectivas presentes nos textos dos autores são bastante diferentes. Para Salm e Leal, o conflito, além de ser inerente à sociedade e, portanto, não deveria existir o objetivo de findar com ele, comporta ainda uma dimensão positiva, ou seja, aqui ele é visto como uma oportunidade de construir novas e positivas relações.

Esta posição dos autores os aproxima dos escritos de Simmel acerca do conflito. Para Simmel (1964) o atributo positivo do conflito residiria no fato de que ele cria um patamar, um espaço onde as partes podem encontrar-se em um mesmo plano situacional impondo-se um nivelamento. Dessa maneira, se estabelece uma condição necessária para que as partes, geralmente díspares e em situação de oposição possam, de fato, efetuar a trama que ele encerra. É um ato de reconhecimento e também produtor de mudanças, possibilitando uma multiplicidade de novos rearranjos coletivos e sociais.

\subsection{A JUSTIÇA RESTAURATIVA EM OUTROS CENÁRIOS E O CASO CANADENSE}

A partir da recuperação de métodos tradicionais de composição de conflitos e do desenvolvimento dos Programas de Reconciliação Vítima-Ofensor (Victim Offender Reconciliation Program -VORP) que surgiram nas décadas de 70 e 80 nos Estados Unidos e Canadá, o movimento em torno da justiça restaurativa têm crescido e cada vez mais países vêm adotando o modelo, bem como toda a filosofia que a acompanha, através de diferentes programas ou abordagens.

Desde de 1989, por exemplo, a Nova Zelândia fez da justiça restaurativa o centro de todo o seu sistema penal para a infância e a juventude ( $c f$. ZEHR, 1990; 2012). Na África do Sul, uma experiência bastante conhecida são as Comissões de Verdade e Reconciliação, além dos círculos restaurativos que nasceram de práticas de comunidades autóctones do Canadá ( $c f$. JACCOUD 1997; 2007).

Na Nova Zelândia, salvo pelas conferências de grupos familiares, os demais modelos restaurativos são aplicados discricionariamente e por encaminhamento. Para ofensas menos graves, o encaminhamento geralmente vem da comunidade, da escola ou instituição religiosa e por vezes a iniciativa surge das próprias partes. A maior parte dos casos, entretanto, ainda 
vem do sistema judiciário neozelandês, sendo que o agente encaminhador varia segundo o caso e a comunidade: pode ser a polícia, o promotor de justiça, o oficial da condicional, o próprio tribunal ou vara criminal, ou até mesmo a penitenciária.

No caso dos tribunais, em geral a indicação da prática restaurativa vem depois da instrução e alegações finais e antes da sentença. Nesses casos, o juiz leva o resultado da conferência em consideração ao sentenciar. Em alguns casos ou varas, o juiz pode ordenar a restituição dos bens e pedir que o valor devido seja decidido através de um encontro restaurativo, que passa a fazer parte da sentença e/ou concessão do livramento condicional (ZEHR, 2012, p.57).

Já o modelo de conferência de grupos familiares, que nasceu naquele país, hoje se tornou o procedimento normativo para as ofensas sob a jurisdição das varas da infância e juventude da Nova Zelândia. Como dito anteriormente, o governo deste país revolucionou seu sistema de justiça para a infância e juventude em 1989, através da inclusão do modelo restaurativo. Esta ação foi uma reação à crise vivida à época na área do bem-estar para crianças e adolescentes, e também às críticas, por parte da população indígena Maori, de que as autoridades utilizavam um sistema colonial imposto e alheio à cultura local.

Embora o sistema judicial tenha sido mantido como retaguarda, o procedimento padrão para a maioria dos crimes cometidos por adolescentes na Nova Zelândia é a conferência de grupos familiares. Estas conferências são organizadas e facilitadas por assistentes sociais pagos pelo Estado, chamados naquele local de Coordenadores de Justiça do Adolescente. Além disso, é interessante ressaltar que, visto que a polícia desempenha o papel de acusador no processo penal neozelandês, também ela deve estar representada nos processos restaurativos (ZEHR, 2012, p.59).

Neste país, assim como acontece no Canadá também, que é outro país expoente e referência na aplicação do modelo, existe um problema estrutural enraizado nessas sociedades, em que as populações indígenas originárias destas regiões (nestes locais são chamados de "first nation people") são sub-representadas nas estatísticas referentes à população geral de seus países e sobre representadas entre as populações carcerárias.

Dito de outra forma, existe uma subrepresentação destes grupos tradicionais comparativamente a outras etnias na contagem da população nacional conjuntamente a uma sobrerepresentação destas populações dentre os encarcerados:

Sobre isso McIntosh (2012) argumenta: 
"Que existem grandes desigualdades entre os Māori e não-Māori está claro. Uma extensa pesquisa sobre a condição Māori mostra que os Māori sofrem desvantagens desde o nascimento. A criança Māori tem maior chance de morrer do que uma criança não-Māori. A criança Māori é menos propensa a ter educação infantil. Os Māori são muito mais propensos a serem suspensos e expulsos da escola, reduzindo, assim, seu desempenho escolar e aumentando a probabilidade de ingressarem na criminalidade juvenil. As taxas de desemprego Māori são significativamente mais elevadas do que as de não-Māori e a renda Māori é consideravelmente menor. Māori são mais propensos a precisar de assistência do governo e a serem dependentes de benefícios governamentais. Muitos Māori vivem em habitações inadequadas e sofrem de um estado de saúde física ou mental pior do que os não-Māori. Desvantagens e diferenças dos Māori estão mais claramente marcadas no sistema de justiça criminal. Os Māori são sobre-representados, tanto como vítimas quanto como agressores e enquanto representam 15\% do total da população da Nova Zelândia, eles compõem mais de $50 \%$ da população encarcerada. Para muitos Māori a vida está ligada ao desemprego, doença, problemas psiquiátricos, pobreza e prisão. Embora a posição e legitimidade da cultura Maori dentro da sociedade da Nova Zelândia tenha sido bastante reforçada desde a década de 1970, com o maior respeito concedido à nossa cultura e língua, o renascimento Māori tem sido bem menos eficaz na resposta as muitas outras desigualdades sociais" $^{23}$. (MCINTOSH, 2012).

McIntosh está descrevendo a situação dos Maori na Nova Zelândia, mas o quadro pintado por este autor não se afasta da realidade vivida pelos grupos autóctones canadenses.

Uma pequena caminhada por algumas das cidades canadenses é suficiente para percebermos nitidamente as marcas sociais de desigualdade que diferenciam os diversos grupos sociais de origens étnicas e clases sociais econômicas diferentes, que convivem mutuamente no Canadá. É bastante simbólico que a grande maioria dos desabrigados, pessoas que circulam nas ruas mendigando, muitas delas com visíveis problemas mentais ou psicológicos, com problemas de vícios em drogas ou bebidas alcoólicas, sejam de origem autóctone.

\footnotetext{
${ }^{23}$ Tradução livre da autora. No original: "That there exist major inequalities between Māori and non-Māori is clear. Extensive research on the Māori condition shows that Māori suffer disadvantages from birth. The Māori infant is more likely to die than the non-Māori infant. The Māori child is less likely to participate in early childhood education. Māori are much more likely to be suspended and expelled from school, thereby reducing their educational achievement and increasing the likelihood of juvenile criminality. Māori unemployment rates are significantly higher than that of non-Māori, and Māori income is considerably lower. Māori are more likely to require government assistance and to be dependent on government benefits. Many Māori live in inadequate housing and suffer a poorer mental and physical health status than non-Māori. Māori disadvantage and difference are most clearly marked in the criminal justice system. Māori are over-represented both as victims and offenders, and while making up $15 \%$ of the total population of New Zealand they make up more than $50 \%$ of the prison population. For too many Māori life is tied to unemployment, illness, psychiatric conditions, poverty and prison. Though the position and legitimacy of Māori culture within New Zealand society has been greatly enhanced since the 1970s, with greater respect afforded to our culture and language, the Māori renaissance has been far less successful in addressing the many other social inequities"
} 
Desse modo, é possível inferir que nestes dois países, Nova Zelância e Canadá, o desenvolvimento de práticas ligadas à justiça restaurativa relaciona-se com questões referentes a estas populações indígenas, ou seja, ambos os países têm suas raízes de aplicação do modelo restaurativo ligadas aos processos de composição de conflitos vindos de suas populações tradicionais.

Assim, tanto o desenvolvimento da justiça restaurativa em si traz a recuperação de uma série de elementos dos meios pelos quais estas populações autóctones resolviam seus conflitos, quanto também é pensada como uma forma de tentar reverter a situação desfavorável em que grande parte destes grupos se encontra atualmente.

Para entendermos melhor esta questão, tomemos mais especificamente o caso canadense. A seção 718.2 do seu Código Criminal exige que o tribunal, ao impor uma sentença, considere os seguintes princípios:

d) a obrigação, antes de considerar a privação de liberdade, de examinar a possibilidade de sanções menos restritivas na medida em que as circunstâncias justifiquem ${ }^{24}$;

e) o exame de todas as sanções substitutivas aplicáveis, que sejam justificadas pelas circunstâncias, especialmente em relação aos delinquentes autóctones ${ }^{25}$.

Em 3 de setembro de 1996, a nova parte (XXIII) do Código Criminal L.R.C. (1985), cap. 46, relativa à determinação da pena entra em vigor. Estas disposições codificaram pela primeira vez o objetivo e os princípios fundamentais de determinação da pena. Particularmente os itens mencionados acima prevêm o exame de todas as sanções substitutivas aplicáveis que são justificadas pelas circunstâncias, mais particularmente no que concerne aos delinquentes autóctones.

Sobre essa determinação do Código canadense, o website do Serviço Correcional do Canadá diz o seguinte:

"Esta seção do Código Criminal é significativa porque nossas prisões estão atualmente superpopuladas com ofensores aborígenes, especialmente nas províncias ocidentais, onde em muitas instâncias, $60-80 \%$ da população prisional é constituída por ofensores

\footnotetext{
24 Tradução livre da autora, no original: d) l'obligation, avant d'envisager la privation de liberté, d'examiner la possibilité de sanctions moins contraignantes lorsque les circonstances le justifient;

25 Tradução livre da autora, no original: e) l'examen de toutes les sanctions substitutives applicables qui sont justifiées dans les circonstances, plus particulièrement en ce qui concerne les délinquants autochtones.
} 
aborígenes" ${ }^{26}$ (Achtenberg, M. disponível em: http://www.cscscc.gc.ca/005/007/forum/e121/e121j-eng.shtml, acessado em $18 / 01 / 2015)$

O mesmo website também cita a seguinte pesquisa, cujos dados, embora não sejam recentes, permitem refletir sobre a questão, que é bastante pertinente neste país:

\begin{abstract}
"Embora pessoas aborígenes representem cerca de 3\% da população adulta no Canadá, eles representam $15 \%$ das internações provinciais para custódia. Tentativas de redução no número de admissões aborígenes em nível federal parecem ter falhado. De fato, a porcentagem de admissões federais de aborígenes continuam a crescer: foi $11 \%$ em 1991-1992, $15 \%$ em 1996-97 e $17 \%$ ano passado. Se isto é um problema para os juízes resolverem, como a recente muito criticada decisão da Suprema Corte sugere, isso é uma outra questão" (Julian V. Roberts, "Recent Correctional Trends", SENTENCING MATTERS; Newsletter 3:1 Autumn 1999. (865 Richmond Square, Montreal, QC, H3J 1V8) ${ }^{27}$.
\end{abstract}

Sobre esta questão, é possível constatar que o problema persiste, como os dados mais atuais disponibilizados pelo site do Serviço Correcional canadense mostram:

Ofensores aborígenes continuam a serem desproporcionalmente representados em todos os níveis do sistema de justiça criminal canadense. Ao final de março de 2007, aborígenes compunham $17 \%$ dos ofensores sentenciados federalmente, embora a população aborígene represente apenas $2,7 \%$ da população canadense adulta ${ }^{28}$.

Especialistas argumentam ainda que o caso Gladue, baseado na seção 718.2 do Código Criminal Canadense, foi a pedra angular para a construção de práticas de justiça restaurativa neste país e abriu as portas para a criação de sentenças alternativas.

\footnotetext{
${ }^{26}$ Tradução livre da autora, no original: This section of the Criminal Code is significant because our prisons are currently overpopulated with Aboriginal offenders, especially in the Western provinces, where in many instances, $60-80 \%$ of the prison population is comprised of Aboriginal offenders

27 Tradução livre da autora, no original: "Although Aboriginal persons represent about $3 \%$ of the adult population in Canada, they represent $15 \%$ of provincial admissions to custody. Attempts to reduce the number of Aboriginal admissions at the federal level seem to have failed. In fact, the percentage of federal admissions that are Aboriginal continues to increase: it was 11\% in 1991-1992, 15\% in 1996-97 and 17\% last year. Whether this is a problem for judges to resolve, as the much-criticized recent Supreme Court judgement suggests, is another question entirely".

${ }^{28}$ Tradução livre da autora, no original: Aboriginal offenders continue to be disproportionately represented at all levels of the Canadian criminal justice system. At the end of March 2007, Aboriginal people comprised $17.0 \%$ of federally sentenced offenders although the general Aboriginal population is only $2.7 \%$ of the Canadian adult population.
} 
Este caso refere-se a uma jovem de origem autóctone canadense, acusada em 3 de junho de 1996 de homicídio em segundo grau. A jovem assassinou seu companheiro em meio a discussões pelo motivo de traição de seu companheiro. $\mathrm{O}$ fato se deu em um momento de forte emoção pela briga entre o casal e após a acusada ter ingerido grandes doses de álcool.

Sobre a aplicabilidade da seção inscrita no código a este caso, o primeiro juiz argumenta que tanto a apelante quanto a vítima eram de origem autóctone, mas sublinhou que eles viviam em meio urbano, externamente à reserva indígena e não dentro de uma comunidade autóctone, propriamente dita. Argumentou que de seu estatuto autóctone não resultava nenhuma circunstância particular que devesse ser levada em consideração. O juiz afirmou que se tratava de uma infração muito grave, pela qual convinha inflingir uma pena de três anos de prisão com interdição de posse de armas durante dez anos.

Após este evento, o tribunal de justiça da Colúmbia Britânica (1997), concluiu unanimamente que o magistrado do processo cometeu um erro ao concluir que o art. $718.2 \mathrm{e}$. não se aplicava pelo fato de a apelante não habitar uma reserva autóctone. O juiz Rowles (dissidente) decidiu, depois de examinar numerosos relatórios e debates parlamentares, que a situação que o art. 718.2 e. visava reformar era o recurso excessivo ao encarceramento de uma forma geral, e particularmente no que concerne ao número desproporcional de autóctones em situação de prisão. Em sua opinião, o artigo conclama ao reconhecimento e à melhoria da situação de discriminação sistemática em que vivem os autóctones dentro do sistema de justiça penal canadense. Destacou ainda a importância de se reconhecer e aplicar concepções diferentes de justiça e de sanções penais que façam parte da dinâmica destes grupos, destancando-se, em particular, a concepção de uma justiça penal que comporte um forte elemento corretivo.

Em consonância com a questão, o site do Serviço Correctional do Canadá afirma que:

Assim, "a decisão Gladue claramente endossou a noção de justiça restaurativa e um regime de condenação fiéis à "cura "como um valor normativo. A cura é um princípio de justiça aborígene que está lentamente sendo incorporado pela legislação penal canadense através da prática do círculo de sentença e programas de remissão de base comunitária. "5 (Judge M.E. Turpel-Lafond, Changing Punishment at the Turn of the Century. Finding Common Ground, "Sentencing within a Restorative Justice Paradigm. Procedural Implications of R. v. Gladue. (1999) 2$)^{29}$.

\footnotetext{
${ }^{29}$ Tradução livre da autora. No original: Thus, "the Gladue decision clearly endorsed the notion of restorative justice and a sentencing regime which pays fidelity to "healing" as a normative value. Healing is an Aboriginal justice principle which is slowly becoming merged into Canadian criminal law through the practice of circle
} 
Esta decisão abre também as portas para a utilização de sentenças alternativas. Dessa forma, de acordo com o Serviço Correcional do Canadá, práticas de justiça restaurativa utilizadas dentro de contextos aborígenes incentivam o uso de sentenças alternativas como as previtas pelas seções 81 e 84 do chamado Corrections and Conditional Release Act (CCRA) canadense.

Sinteticamente, a seção 81 propõe acordos de custódia geral de maneira a transferir o ofensor de origem aborígene para uma comunidade (também aborígene), em uma situação não institucional, mas com supervisão, tratamento e programação controlados vinte e quatro horas por dia por membros da comunidade. Três tipos de arranjos são possíveis através desta seção para facilitar a transferência de um ofensor autóctone para um local determinado de recuperação espiritual ou de cura, ou outro espaço de tratamento que se localize em uma área urbana.

Já a seção 84 capacita comunidades autóctones com a oportunidade de participarem dos planos de soltura do ofensor de instituições penais. Segundo esta seção, o plano de liberação deve contemplar as preocupações e necessidades da comunidade, bem como as do ofensor. Esta iniciativa objetiva uma melhor reintegração do ofensor em seu meio e sua comunidade, o que passa a se tornar parte de um processo curativo para todos os envolvidos no caso: a comunidade, o ofensor e a vítima.

De acordo com a instituição canadense prestadora deste serviço, esta "mudança de filosofia" também pode ser vista também dentro de institutições prisionais, onde programas específicos voltados aos ofensores autóctones estão sendo desenvolvidos. Idosos nativos ou trabalhadores que têm esta conexão com a comunidade organizam círculos curativos, de aconselhamento e oportunidades de crescimento pessoal para assistir ofensores a fim de que possam mudar seu estilo de vida, uma vez que se encontrem em situação de liberdade condicional. Da mesma forma, a cultura da prisão em si estaria mudando, de acordo com os implementadores destas iniciativas, já que membros da comunidade ou trabalhadores ligados à cultura aborígene passam a trabalhar conjuntamente a outros profissionais do sistema prisional para criar soluções mais pacíficas para os conflitos que ocorrem dentro da instituição

sentencing and community based diversion programs." Para mais detalhes ver: Decisão da Corte Suprema do Canadá (R. c. Gladue, [1999] 1 R.C.S. 688) 
prisional e desenvolver opções inovadoras para a prática da justiça restaurativa nestes espaços.

Diversos autores como Zehr (2008) afirmam que as abordagens circulares surgiram nas comunidades aborígenes do Canadá. Para descrever o processo circular, o juiz canadense Barry Stuart, em cuja vara, um desses círculos foi reconhecido pela primeira vez no país através de uma sentença judicial, escolheu o termo "Círculos de Construção de Paz". Hoje estes círculos têm inúmeras aplicações neste país. Além dos círculos de sentenciamento, que objetivam determinar sentenças para processos criminais, há círculos de apoio (em preparação a círculos de sentenciamento), círculos para lidar com conflitos no ambiente de trabalho, e até círculos como forma de diálogo comunitário (ZEHR, 2008, p.62).

A prática dos círculos de sentença, chamados também de círculos de determinação da pena, foram sistematizados pela primeira vez no território de Yukon, no Canadá, em 1992, notadamente pelo incentivo do juiz Barry Stuart. Este magistrado, em um julgamento que depois se tornou célebre, decidiu tomar sua decisão inspirando-se nos círculos tradicionais autoctónes de composição de conflitos. Dessa forma, desde 1992 os círculos de sentença tiveram certa expansão, particularmente nos territórios de Yukon e do noroeste e nas províncias Saskatchewan e do Manitoba (no Québec estes mecanismos são ainda pouco utilizados).

Jaccoud (1999) em uma análise crítica acerca da abordagem da justiça restaurativa em meios autóctones, observou que existem diferentes graus de participação comunitária e de independência das instituições formais de justiça no Canadá. Existem também diferentes critérios para se enviar ou não um conflito para um círculo: o conflito não pode ser nem pouco grave nem muito grave, deve ser mediano.

A autora cita como exemplo a declaração do juiz Barnett, que estima que as situações que não afetem suficientemente a comunidade são uma perda de tempo: "No plano financeiro, é preciso reconhecer que o atual desenvolvimento de projetos de justiça restaurativa, em meio autóctone ou não, é fortemente motivado pelas pressões de um Estado providência atento a todas as opções suscetíveis de contribuir à uma redução de suas despensas"30. (JACCOUD, 1999, p.96).

A autora argumenta também que os círculos de sentença são aplicados em comunidades Inuit, mas o círculo é uma tradição ameríndia que não é observada nas práticas

\footnotetext{
30 Tradução livre da autora. No original: «Au plan financier, il faut reconnaître que le développement actuel des projets de justice réparatrice, en milieu autochtone ou non, est fortement motivé par les pressions d'un État providence à l'affût de toute option susceptible de contribuer à une réduction de ses dépenses».
} 
ancestrais de gestão de conflitos dos povos Inuit. Dessa forma, ao tentar estabelecer meios de administração de conflitos alternativos, partindo-se do pressuposto de que o sistema de justiça oficial é uma imposição de um modelo alheio sobre populações que compartilham de outros ritos, perdeu-se de vista que a própria utilização dos círculos pode representar pra estes grupos uma nova imposição. Muda-se o cenário, mas o problema persiste. Parece, na opinião da autora, que os incentivadores da justiça restaurativa também se esqueceram de que não existe um sistema global de justiça que se aplique a todas as comunidades autóctones. Ignora-se, assim, uma multiplicidade de práticas a partir de culturas diversas e o processo de imposição de modelos continua. Nas palavras da autora:

Este descompasso entre o princípio que o Estado atribui às tradições autóctones nessas novas iniciativas de justiça e as verdadeiras práticas ancestrais de algumas nações ameaça perpetuar o sentimento de alienação vivida por estas Primeiras Nações ao contato com o sistema de justiça estatal, sentimento que o Estado procura justamente atenuar através destas novas abordagens. ${ }^{31}$ (JACCOUD, 1999, p.100)

Além disso, a autora argumenta, ainda, que a comunidade e sua participação nos rituais de composição de conflitos também pode reforçar a punição e o estigma, contrariamente ao que se poderia pressupor inicialmente:

"Crawford considera que a justiça comunitária pode significar também limitação de espírito, intolerância, constrangimento, jogos de poder e punição, enquanto Depew considera que os projetos de justiça comunitária vêem a assemelhar-se às estruturas que deveriam substituir, com a diferença que oferecem menos proteção legal para os principais envolvidos. Segundo Depew, o paradigma da cura é redutor porque ignora as questões relativas às estruturas de poder $^{32}$." (Id. 1999)

Harrison, Meric et Dixon (1995) são autores que falam ainda de como muitas vítimas relatam um sentimento de frustação ao entenderem que maior atenção foi dada ao ofensor, mesmo nos procedimentos mais informais.

\footnotetext{
31 Tradução livre da autora. No original: «Ce décalage entre le principe que l’État attribue aux traditions autochtones dans ces nouvelles initiatives de justice et les véritables pratiques ancestrales de certaines nations menace de perpétuer le sentiment d'aliénation éprouvé par les Premières nations au contact du système de justice étatique, sentiment que 1'État cherche justement à atténuer par le biais de ces nouvelles approches».

32 Tradução livre da autora. No original: «Crawford estime que la justice communautaire peut aussi signifier étroitesse d'esprit, intolérance, contraintes, jeux de pouvoir et punition alors que Depew considère que les projets de justice communautaire en viennent à ressembler aux structures qu'ils sont censés remplacer, à la différence près qu'ils offrent une moins grande protection juridique aux principaux concernés. Selon Depew, le paradigme de guérison est réducteur car il passe sous silence les questions relatives aux structures de pouvoir ».
} 
Jaccoud finaliza seu artigo afirmando que um dos pré-requisitos para a construção de meios mais construtivos de avaliações destes programas consistirá, no futuro, na despolitização de pesquisas e seus resultados, de modo que elas sirvam como ferramentas úteis para melhorar as iniciativas em função das necessidades das comunidades, e não como argumentos para alimentar o discurso dos apoiadores da integração ou da autonomia política. Por fim, deve-se igualmente evitar que, sob o slogan do envolvimento aborígene na administração da justiça, o Estado não encontre, especialmente através de círculos de sentença, uma maneira de criar uma nova forma de legitimidade para sua intervenção.

A conclusão da autora é que os círculos de cura (healing circles) são mais amplamente empregados para tentar empoderar comunidades nativas enquanto que os círculos de sentença constituem-se em apenas mais um degrau para criar uma nova legitimidade para a intervenção do sistema de justiça estatal.

Partindo do artigo de Jaccoud, que discute a aplicação do modelo de justiça restaurativa em meios autóctones, parece que a ideia de reparação das relações, como proposto pela justiça restaurativa, faz mais sentido quando se trata de comunidades (em sentido weberiano). A ideia parece se ancaixar mais no sentido de comunidade, como proposto por Weber, que de sociedades. Nesse sentido, cabe a questão: que relações reparar quando não há relações diretas entre os envolvidos no crime? A utilização da justiça restaurativa parece ser apropriada quando os conflitos se dão entre pessoas que possuem um vínculo emocional, familiar ou mesmo comunitário. Mas como a filosofia da justiça restaurativa pode ser benéfica nos casos em que a vítima e o ofensor não têm qualquer contato, relação ou identificação?

Existem também no Canadá os chamados Círculo de Apoio e Responsabilização desenvolvidos para atender perpetradores de crimes sexuais. Em boa parte dos Estados Unidos e Canadá, depois de cumprirem suas sentenças, indivíduos que cometeram crimes sexuais retornam às suas comunidades que oferecem pouco apoio em termos de reinclusão e ressocialização. Esses círculos constituem, portanto, uma maneira de tentar colaborar com a reinserção desses ofensores sexuais em suas comunidades.

Além disso, assim como acontece no Brasil, algumas iniciativas de círculos restaurativos estão sendo aplicadas em escolas na cidade de Ottawa, quadro semelhante aos programas brasileiros analisados pela pesquisa. Entrei em contato com uma pesquisadora canadense e como meu estágio (sanduíche) foi realizado nesta cidade, vislumbrei a possiblidade de fazer um pequeno campo tratando deste programa nas escolas. Isso não foi possível e o argumento que a interlocutora utilizou remete à confidencialidade. O que, por sua 
vez, me leva a pensar que talvez no Canadá existam também alguns entraves aos pesquisadores, o mesmo que acontece no Brasil, segundo minhas experiências enquanto pesquisadora da área.

Ainda sim, foi possível obter algumas informações: nas escolas a justiça restaurativa tem sido aplicada nos sistemas de re-entry, ou seja, nos casos em que alunos estão prestes a serem expulsos de suas escolas ou casos em que a transferência já foi decidida e é pensada no sentido de se não evitar, ao menos colaborar na inserção ou re-inserção destes alunos.

Através de uma pesquisa pelas atividades prestadas pelo Serviço Correcional do Canadá - Correctional Service in Canada ${ }^{33}$ também foi possível verificar outros tipos de iniciativas relacionadas à justiça restaurativa sendo utilizadas neste país. Foi possível notar que são realizados círculos de sentença no sistema de justiça e também healing circles $^{34}$, embora haja a crítica de que eles também sejam informados pelo sistema penal, como pudemos inferir do trabalho de pesquisadores como Jaccoud.

Já em relação à aplicação do modelo nas Cortes de justiça, infere-se que depende do juiz a aplicação de um modelo alternativo de justiça ou não. A decisão sobra a utilização da justiça restaurativa fica a cargo do magistrado responsável pelo caso, o mesmo que acontece em nosso país.

Existe também um programa chamado Restorative Opportunities, promovido pelo Serviço Correctional do Canadá, que oferece às pessoas envolvidas em um ato criminoso, direta ou indiretamente, uma chance de se comunicarem com o ofensor que causou o dano. Esta chamada oportunidade restaurativa é um programa que atua após a sentença e a participação é voluntária para todos os interessados. O programa explora oportunidades de uso de vários modelos de mediação vítima-ofensor, a fim de encontrar aquele que melhor se encaixe nas necessidades dos participantes (definidas pelos próprios participantes) com a ajuda de um mediador profissional. Assim, não necessariamente o programa se aplica a todos os casos nos quais exista interesse, tampouco são realizados encontros face-a-face em todas as situações.

No caso da mediação vítima-ofensor, ela é vista pelos organizadores do programa como um processo no qual um mediador treinado da comunidade prepara vítimas e ofensores interessados em se comunicarem e dá a eles a oportunidade de se encontrarem em um espaço

\footnotetext{
${ }^{33} \mathrm{O}$ sistema aqui é dividido em dois: federal para sentenças de mais de dois anos e provincial para menores que dois.

${ }^{34}$ Algo como círculos de cura, em português.
} 
estruturado e seguro. A participação no programa é disponível às pessoas afetadas por uma ofensa que gostariam de se comunicar com o ofensor que causou o dano.

Nesse caso, a proposta é somente incentivar o diálogo e os benefícios que dele possam surgir, sem, contudo, afetar o processo criminal que caminha sem a "interferência" da justiça restaurativa, ou seja, o círculo ou a mediação vítima-ofensor não interfere no julgamento ou sentença do acusado que responde criminalmente por seus atos.

De acordo com o site do Serviço Correcional do Canadá o uso da justiça restaurativa está amparado pela legislação e políticas públicas governamentais, pois existem:

- Provisões no Código Criminal, no chamado Youth Criminal Justice Act canadense, também no Corrections and Conditional Release Act, e inúmeras políticas federais, provinciais e territoriais apoiam a justiça restaurativa.

- Cortes canadenses, incluindo a Suprema Corte do Canadá, reconheceram o valor da justiça restaurativa ${ }^{35}$.

A respeito do histórico de utilização do modelo neste país, em 1989, o Serviço Correcional do Canadá fundou um programa de mediação vítima-ofensor, que focou em crimes mais graves. De acordo com esta instituição, esta teria sido a primeira aplicação de princípios e processos de justiça restaurativa para lidar com ofensas graves no Canadá. Depois disso, teria sido somente a partir da segunda metade da década de 1990 que políticos e formuladores de políticas públicas começaram a examinar e a considerar o potencial do modelo restaurativo.

Desde 1996, o Serviço Correcional do Canadá (CSC) afirma ter explorado a justiça rstaurativa através da criação de uma Divisão de Justiça Restaurativa e Resolução de Disputas (Restorative Justice and Dispute Resolution Division - RJDR). Em 2001, o Serviço Correcional deu mais um passo em direção ao modelo restaurativo ao criar um projeto piloto de aplicação da justiça restaurativa em um ambiente correcional. Para isso criou-se uma Unidade de Justiça Restaurativa (Restorative Justice Living Unit - RJU) em uma instituição prisional, a Grande Cache Institution (GCI), integrando princípios e valores restaurativos em operações nas prisões.

\footnotetext{
${ }^{35}$ Endereço do website: http://www.csc-scc.gc.ca/index-eng.shtml (acessado em 09/06/2015).
} 
De 1999 a 2001, o Fundo do Governo Federal para Resolução de Disputas - Federal Government Dispute Resolution Fund - financiou 14 projetos piloto. A unidade de Justiça Restaurativa (RJU) foi uma extensão do sucesso do projeto piloto chamado Making Things Right (MTR). Foi desenvolvido e lançado por um ex-agente da condicional na instituição prisional Grande Cache Institution (GCI) e utilizou encontros como espaços para encorajar ofensores a contemplar suas ofensas e o impacto que tiveram na vida das vítimas.

Existem também algumas premiações anuais no Canadá como o National Ron Wiebe Restorative Justice Award. Este prêmio se destina à profissionais que tenham se destacado durante o ano em termos de promoção dos valores e princípios da justiça restaurativa, "à serviço da justiça e paz", como o website da premiação indica. Desde 1999, esta honraria faz homenagem a Ron Wiebe ${ }^{36}$, que foi um profissional do Serviço Correcional do Canadá, comprometido com a causa justiça restaurativa.

Esta e outras premiações acontecem anualmente durante os eventos que marcam a semana de justiça restaurativa no Canadá. Este é um evento, o qual tive a oportunidade de participar durante meu estágio sanduíche no país, muito aguardado pelos mais diversos profissionais que trabalham com o modelo alternativo. Pessoas das mais diversas províncias se reúnem neste evento que congrega diferentes tipos de acontecimentos no mesmo espaço: são ofertados aos participantes workshops, seminários, e os momentos de socialização entre os profissionais são alguns dos momentos mais aguardados.

Adiante na tese falarei mais a respeito dos seminários e workshops brasileiros acerca do tema que pude assistir ou participar no Brasil. Fazendo uma comparação com o que vi no Canadá, pude perceber que há mais semelhanças do que dessemelhanças. A interação entre os profissionais, os tipos de abordagens restaurativas presentes nos eventos e os diferentes profissionais ou grupos que realizam capacitações são bastante similares, a diferença, como poderia-se esperar, reside no fato de que, comparativamente ao Canadá, o contexto brasileiro nos quais esses eventos propulsores da justiça restaurativa acontecem é bastante incipiente. No Canadá contam com mais recursos, mais estrutura e maior reconhecimento.

Assim como acontece no Brasil, no Canadá espalharam-se pelo país diversas iniciativas de justiça restaurativa, de modo que se torna difícil traçar um perfil geral. Depende da localidade e da forma de aplicação, não existindo um controle ou estudos que abordem e comparem todas as formas de aplicação da justiça restaurativa daquela nação.

\footnotetext{
${ }^{36}$ Para saber mais Reflections of a Canadian prison warden - the visionary legacy of Ron Wiebe: an unfinished conversation. Published by the Correctional Service of Canada - 2000.
} 
Os autores que trabalham o tema neste local também divergem em suas análises. Um dos principais autores, conhecido no campo da literatura especializada em justiça restaurativa, é o juiz supracitado, Barry Stuart, que colaborou na expansão e reconhecimento da práticas de círculos de sentença e cura no Canadá. Foi um dos principais defensores do modelo restaurativo, reconhecido internacionalmente.

Diferentemente, outros autores como Mylène Jaccoud, outra referência na área, produzem estudos mais críticos. Esta autora mais especificamente trabalhou no tema da justiça restaurativa em sua intersecção com populações autóctones de algumas regiões do Canadá.

Além destes autores citados existem aqueles que embora não estejam trabalhando diretamente o tema da justiça restaurativa podem contribuir enormemente para avanços no tema na medida em que estudam o sistema de justiça criminal canadense ou sistemas de pensamento que sustentam esses modelos de justiça como Pires (2013), através de sua teoria da Racionalidade Penal Moderna.

Vimos também como, diferentemente do que acontece no Brasil, no Canadá, além de a justiça restaurativa ser utilizada há mais tempo, ela tem suas raízes, ou fundamentações básicas, alicerçadas em práticas comuns aos grupos autóctones locais, como nos descreve Jaccoud em seus trabalhos, e não restringe sua aplicação a casos de conflitos envolvendo crianças e adolescentes.

Comparativamente à situação que se encontra o Canadá em relação à utilização da justiça restaurativa, é possível perceber como concretamente os limites de aceitação do modelo no Brasil estão ainda muito fechados (também em relação ao que encontramos em outros países como a Nova Zelândia).

A justiça restaurativa apresenta nestes lugares o mesmo autorretrato que definimos na seção anterior da tese e, por isso, também no Canadá tem limites, demarcações dos espaços nos quais pode ou não intervir (um exemplo destes limites pode ser visto no caso Gladue), mas em nosso país seus usos têm sido mais reduzidos. Além disso, parte destes limites advém da Racionalidade Penal Moderna ${ }^{37}$, como já indicou Pires (2013), que permite maior ou menor espaço para a atuação de modelos de justiça alternativos.

\footnotetext{
${ }^{37} \mathrm{O}$ conceito será melhor abordado adiante na tese.
} 
Os modelos de aplicação de justiça restautiva no exterior também receberam críticas. Assim como Jaccoud, outros autores também vêm apontando os limites dessas inciativas como Matthews (2006). Este autor ressalta como as experiências de justiça restaurativa que emergiram na década de 90, como as Conferências Waga-Waga em Nova Gales do Sul, Austrália, conferências familiares na Nova Zelândia e experências nos Estados Unidos e Reino Unido foram criticadas em suas aspirações no sentido de resgatar antigas práticas de mediação de conflitos, como argumenta Daly (2002).

Harry Blagg (1997) em sua análise do modelo Waga-waga diz sobre as conferências que elas (re) legitimam novas formas de dominação e de extensão de poderes de controle:

"O efeito geral dessas conferências é agravar desigualdades, individualizar problemas sociais e privatizar disputas. Estas práticas são rotineiramente justificadas em nome da "comunidade" ou da 'segurança de comunidade'. Paradoxalmente, os aborígines são marginalizados do maisntream da 'comunidade' na Austrália” ${ }^{\text {"38. }}$. (BLAGG, 1997)

Matthews (2006) argumenta como os focos dos programas têm sido os grupos marginalizados, mas acrescenta que em uma sociedade crescentemente multicultural e diversa programas de justiça restaurativa têm servido mais para impor um sistema de valores dominante em grupos que poderiam aderir a outros valores ou normas marginais.

No caso de programas voltados para os adolescentes temos a pesquisa de Kathleen Daly (2001) sobre conferências familiares entre jovens que cometeram delitos, na Nova Zelândia. Seus dados são alarmantes e contradizem autores como Zehr que têm se empenhado em divulgar os resultados positivos destas iniciativas neste país:

\footnotetext{
"Descobriu que pouco menos de um terço dos jovens infratores disse que a conferência não foi importante para eles, enquanto mais da metade disse que não tinha pensado sobre o que diriam às vítimas antes da conferência. A título indicativo, mais de $40 \%$ disseram que eles não se arrependiam ou estavam menos arrependidos em relação à vítima após a conferência, enquanto que apenas $28 \%$ das vítimas entrevistadas acreditava que o agressor estava genuinamente
}

\footnotetext{
${ }^{38}$ Tradução livre da autora. No original: "The overall effect of these conferences is to compound inequalities, individualize social problems and privatize disputes. These practices are routinely justified in the name of the 'community' or 'comunity safety'. Paradoxically, aborigines are marginalized from the maisntream 'community' in Australia".
} 
arrependido. Cerca de $18 \%$ das vítimas saiu da conferência descontente e em $9 \%$ dos casos as vítimas se sentiram intimidadas "39 (Daly, 2001)

Matthews (2006) finaliza argumentando sobre a pesquisa da autora que é evidente a partir destes dados que neste tipo de conferência, que envolve principalmente os jovens, uma porcentagem significativa dos infratores não levou o procedimento a sério, enquanto que outros só se envolveram no processo a fim de reduzirem a pena que poderiam receber. Certamente, muitos desses encontros são ineficazes ou contraproducentes, com muitas vítimas se sentindo pouco valorizadas ou até mesmo intimidadas.

Richard Young (2001) conduziu outra pesquisa realizada em programas em Bethlehem, Pensilvânia, Estados Unidos, Canberra, Austrália e outras regiões da Inglaterra, sobre programas que contam com a participação de policiais. A pesquisa concluiu que os procedimentos eram muito controlados pelos profissionais. Assim, em vez de empoderar os participantes acabavam empoderando mais a corporação profissional da polícia. Além disso, foi possível observar também que os procedimentos tendiam a focar mais sobre o ofensor que sobre a vítima cujo empoderamento seria um dos principais objetivos previstos pela justiça restaurativa.

Já David O’Mahoney e Jonathan Doak (2004), ao analisarem programas piloto na Irlanda, encontraram evidências que sugerem um processo de "oficialização" de casos que de outra forma não ingressariam no sistema; ou porque os ofensores eram muito jovens ou porque não haviam leis que se aplicavam aos casos atendidos. Nas palavras dos autores:

"Uma das maiores preocupações decorrentes dos pilotos foi que eles parecem trazer ofensores muito jovens e inofensivos que consequentemente experimentaram um processo muito exigente de prestação de contas que, em nossa opinião, era desproporcional ao dano causado. Em $80 \%$ dos casos que examinamos as ofensas eram relativas a propriedades de valor inferior a 15 libras. Não era incomum nos depararmos com casos em que uma quantidade considerável de tempo da polícia tinha sido investido na organização de uma

\footnotetext{
${ }^{39}$ Tradução livre da autora. No original: "She found that just under a third of the young offenders said that the conference was not important to them, while over half said that they had not thought about what they would say to victims before the conference. Indicatively, over 40 per cent said that they were not sorry or were less sorry for the victim after the conference, while only 28 per cent of the victims interviewed believed that the offender was genuinely sorry. Some 18 per cent of victims left the conference upset and in 9 per cent of cases victims felt intimidated".
} 
conferência para tratar do roubo de uma barra de chocolate ou uma lata de refrigerante"40 (O’MAHONEY, DOAK, 2004, p. 495).

Essa situação, além se assemelhar em alguns pontos ao quadro encontrado no programa de São Caetano do Sul, em termos de atendimento de casos bastante simples, que muitas vezes não se constituíam enquanto crimes e que passavam a ser oficializados, corrobora também o argumento de autores como Ashworth (2001). Este autor indica que há um crescente número de críticas que sugerem que, em vez de se apresentarem como uma opção mais construtiva e progressista de justiça, as várias formas de justiça restaurativa têm envolvido a erosão de direitos e garantias legais, uma indefinição de procedimentos cíveis e penais e a construção de uma "justiça barata" ou de segunda classe.

Resta a questão: Se a justiça restaurativa vem sendo tão censurada, e o teor de muitos trabalhos sugere não haver esperanças para o modelo, porque ela ontinua se constituindo em uma pauta amplamente discutida e incentivada? Uma primeiro resposta, com base nas entrevistas realizadas e nas observações participantes, seria porque grande parte dos envolvidos com o sistema de justiça criminal estão descontentes com seus trabalhos, descrentes no seu funcionamento e benefícios e procurando por alternativas.

\subsection{REVISÃO BIBLIOGRÁFICA}

A justiça restaurativa tem sido cada vez mais estudada por diversas áreas do conhecimento humano. Faltam, entretanto, trabalhos na área da sociologia que abordem especificamente o tema - é nesta brecha que se insere o presente trabalho.

$\mathrm{Na}$ área do direito, os trabalhos que versam sobre a justiça restaurativa tentam definí-la e almejam, de uma maneira geral, verificar em que medida poderia ser aplicada no Brasil, levando em conta nossas especificidades e tendo como referência de análise as vertentes garantista ou mesmo abolicionista da área. Exemplos deste tipo de estudo são o de Pallamolla (2009) e Sica (2007).

Já os trabalhos na área da psicologia têm atentado para o momento da resolução dos conflitos de acordo com os princípios orientadores da justiça restaurativa; trabalhos como o de

\footnotetext{
${ }^{40}$ Tradução livre da autora. No original: one of the greatest concerns arising from the pilots was that they appeared to draw in some very young and petty offenders who consequentely experienced a very demanding process of accountability that in our opinion was disproportionate to the harm caused. Some $80 \%$ os cases that we examined were for offences concerning property worth less than 15 pounds. It was not uncommon to come across cases where a considerable amount of police time had been invested in arranging for a full conference for the theft of a chocolate bar or a can of soft drink.
} 
Schimidt (2010) abordam os círculos restaurativos e seus participantes em termos de incorporação de papéis, num viés possibilitado pelo psicodrama.

Existem ainda publicações que tratam dos programas de justiça restaurativa que funcionam no Brasil; em geral, são organizados pelos próprios envolvidos nestas iniciativas, como o livro Justiça restaurativa e comunitária em São Caetano do Sul: aprendendo com os conflitos a respeitar direitos e promover cidadania (2008) e as publicações do Justiça para o Século XXI, que abordam os programas de justiça restaurativa implantados na região Sul do país.

Finalmente, há também os livros: Justiça restaurativa (2005), do Ministério da Justiça e Novas direções na governança da justiça e da segurança (2006), que são obras organizadas e publicadas com o apoio do Ministério da Justiça e que reúnem vários artigos sobre o tema, mesclando, num mesmo espaço, artigos com diferentes propostas e de autores que estão dialogando em áreas diversas.

É certo que existem trabalhos consolidados no país a respeito de temas afins, como é o caso da literatura brasileira a respeito do acesso à justiça e de iniciativas do Judiciário que vem na esteira das mudanças possibilitadas pelo período de redemocratização, além de trabalhos sociológicos que versam sobre questões concernentes, como a administração de conflitos e a punição. Mas faltam estudos de conteúdo crítico a respeito de modelos alternativos de justiça como a justiça restaurativa, especialmente com o aporte trazido da sociologia e mais especificamente das sociologias da punição e administração de conflitos.

Em nosso país, até a década de 1980, o sistema de justiça foi um tema tratado majoritariamente por juristas. Ainda que diversos autores clássicos do pensamento social tenham trabalhado as relações da sociedade com Direito, só podemos falar de uma sociologia do Direito e do campo jurídico a partir desta década. Como as motivações dos pesquisadores foram permeadas pelo contexto social e político de transição do governo autoritário para o regime democrático, esta transição foi e ainda é motivo central das produções do campo tendo especialmente o tema do acesso à justiça ganhado destaque (SINHORETTO, 2011).

Junqueira (1996) divide ainda o movimento acadêmico em torno da questão do acesso à justiça em dois pólos: o primeiro se refere às pesquisas sobre acesso coletivo à justiça, que teriam dominado a cena durante a primeira metade da década de 1980; o segundo diz respeito às investigações de formas estatais e não estatais de resolução de conflitos estando, ambos, sob a influência dos trabalhos de Boaventura de Sousa Santos. Em relação ao primeiro agrupamento destaca-se a produção de Falcão $(1981$; 1984) a respeito dos direitos coletivos, 
pluralismo jurídico e acesso à justiça. Dentro do segundo MacDowell dos Santos (1989) e D’Araújo (1996) sobre os Juizados Informais de Conciliação e Juizados de Pequenas Causas.

As maneiras informais de administração de conflitos continuam sendo uma das principais matérias para trabalhos neste campo e, embora não existam ainda dados gerais e substanciais sobre todos os programas alternativos de justiça brasileiros ${ }^{41}$, existem, por outro lado, algumas pesquisas na área das ciências sociais bastante aprofundadas, sobre iniciativas pontuais. Entre elas, podem ser citadas: a de Sinhoretto (2011), que pesquisou os Centros de Integração da Cidadania (CICs), em São Paulo; Simião (2007), que realizou estudos em um Centro de Mediação de Conflitos na Universidade Federal de Minas Gerais; e Oliveira (2010), que se deteve sobre Centros de mediação e Balcão de Direitos em Pernambuco e Rio de Janeiro.

Quanto às pesquisas sobre os Juizados Especiais Criminais e Cíveis, todavia, já existem muitos debates e uma produção acadêmica consistente.

Os Juizados Especiais foram abordados de maneira mais geral por Vianna et al (1999) e Sadek (2002). Mais especificamente sobre os Juizados Especiais Cíveis em São Paulo há o trabalho de Cunha $(2001 ; 2004)$ e sobre eles no Rio de Janeiro, Amorim (2006). Em relação aos JECrim(s), são muitos os trabalhos, entre eles os de: Amorim, Burgos e Kant de Lima (2002; 2003), sobre os Juizados Especiais Criminais Estaduais no Rio de Janeiro; Azevedo (2000; 2001) e Campos (2002), sobre aqueles em Porto Alegre; Debert e Oliveira (2004) e Oliveira (2006), em Campinas; Faisting (1999), em São Carlos e Izumino (2003), em São Paulo.

Tais trabalhos, de uma forma geral, realizam uma análise crítica dos Juizados Especiais, que se inscrevem dentro de um movimento do Judiciário criados às vistas de uma ampliação do acesso à justiça e sua agilização.

Há ainda os que enxergam na excessiva burocratização dos processos uma verdadeira justiça de "linha de montagem", em que linguagens, categorias, formulários ou mesmo sentenças são padronizadas, a partir de uma pressão por prudutividade que se sobrepõe, inclusive, à satisfação das partes como objetivo principal (RIBEIRO; CRUZ; BATITTUTI, 2004; SAPORI, 2006).

\footnotetext{
${ }^{41}$ O Ministério da Justiça reuniu, em 2005, dados sobre 67 programas brasileiros alternativos de justiça, sediados em 22 estados do Brasil. O relatório originado da pesquisa se intitula "Acesso à Justiça por Sistemas Alternativos de Administração de Conflitos" e deste mapeamento pode-se inferir que não existia um número considerável de experiências funcionando regulamente no país; ainda hoje pode-se dizer que a maior parte delas não está consolidada.
} 
Além das produções supracitadas, é preciso também destacar a relevância de trabalhos de caráter etnográfico para avanços do debate, inclusive brasileiro, quanto ao tema da administração de conflitos. Na área da antropologia jurídica há as referências de: Guliver (1979), Nader (1994), Falk Moore (2006), Black e Baumgartner (1993); e, no contexto brasileiro, ganham relevância os trabalhos de Schiritzmeyer (2001; 2007), Miraglia (2005); Schuch (2006) e Cardoso de Oliveira (2002).

Como se pode entrever, a justiça restaurativa, mais que apenas instituir novas práticas de justiça, abriu, sobretudo, um campo para estudos de diversas áreas, no qual podemos observar diversas disputas em curso em torno de suas definições. Ao mesmo tempo, o campo das ciências sociais brasileiro tem muito a contribuir para o desenvolvimento de novas pesquisas sobre o tema, como é o caso do presente trabalho que ainda não esgotou suas possibilidades de análise. 
CAPÍTULO 2:

\section{QUESTÕES PROFISSIONAIS RELACIONADAS À JUSTIÇA RESTAURATIVA}


Este capítulo, que tem por foco problematizar questões profissionais relacionadas ao tema da justiça restaurativa, está dividido em quatro tópicos. No primeiro serão apresentadas algumas das representações que os profissionais envolvidos com os programas de justiça restaurativa no estado de São Paulo detêm sobre este modelo alternativo. O exame destas representações, obtidas por meio de entrevistas que contaram com roteiros semi-elaborados, é importante uma vez que não somente possibilita a comparação posterior com as práticas observadas, mas também pelo fato de fazerem parte do processo dinâmico de construção e reconstrução dos conceitos de justiça restaurativa que estes agentes sustentam.

No segundo tópico serão abordadas as disputas profissionais existentes neste campo, especialmente entre os juízes, já que têm sido eles os principais líderes dos programas em nosso país.

No terceiro tópico será tratada a questão de como as diferentes definições de justiça restaurativa se constituem em formas de agência dos indivíduos, traduzindo-se muitas vezes em estratégias de defesa e enfrentamento das críticas. As críticas, por sua vez, são interpretadas pelos mesmos agentes como falta de conhecimento em relação ao modelo da justiça restaurativa.

Por último, o quinto tópico do capítulo apresenta o novo mercado das capacitações, possível a partir do surgimento de grupos especializados na promoção de cursos para aqueles que possivelmente venham a trabalhar nos programas de justiça restaurativa. Cabe destacar também que estes grupos rivalizam entre si pelas metodologias utilizadas e disputam os espaços nos quais podem atuar.

\subsection{REPRESENTAÇÕES SOBRE O MODELO}

Toda a conceituação em torno da justiça restaurativa não se baseia somente no que a literatura a seu respeito diz. Da mesma forma como são importantes as contribuições dos autores, também o são as imagens construídas pelos atores envolvidos com este conteúdo crítico. Assim, neste momento da tese o foco são as representações que os profissionais comprometidos com o modelo restaurativo detêm e como isso influencia a maneira como a justiça restaurativa tem sido aplicada em nosso país.

$\mathrm{O}$ discurso de sucesso que estes personagens sustentam contribui para que ela seja cada vez mais um assunto em pauta e o número de iniciativas têm crescido em nosso país desde os primeiros projetos piloto implantados em 2005. Ao mesmo tempo, essas 
representações dos profissionais muitas vezes constrastam com a realidade dos programas e com a maneira pela qual a justiça restaurativa têm sido colocada em prática.

Segundo aqueles engajados na aplicação da justiça restaurativa no país, ter entrado em contato com a pauta e seus valores foi algo que reverberou para outras dimensões de suas vidas, o lado mais pessoal, de relacionamentos e a profissão que exercem além do tempo dedicado ao funcionamento dos programas. Além disso, algumas declarações obtidas em entrevistas sugerem que a própria disponibilização para atuar num programa desse cunho já seria indicativa de que se trata de um profissional com uma visão diferente, mais humana do que aqueles vinculados à ortodoxia da profissão:

Também eu entendo que não tem como você entrar num caminho desse, numa proposta dessa se você também não rever seus valores não estar se questionando, se problematizando e mudando também. (...) o fato de você estar defendendo uma bandeira dessas de cultura de paz, já te faz diferente. (Juiz entrevistado)

Os entusiastas do novo modelo em geral apontam como o conhecimento que tiveram do método mudou sua atuação profissional por possibilitar ampliar a visão que se tinha do conflito. Como indicado em entrevista, por um promotor envolvido na implantação do programa em São Caetano do Sul, "passa-se de um solucionador do problema para um encaminhador de soluções", já que as propostas de ressarcimento devem vir das próprias partes, intentando-se, desse modo, uma responsabilização por parte do ofensor, ao mesmo tempo em que se traz para a comunidade em geral essa sensação de envolvimento.

(...) sai daquela coisa de gabinete, inclusive muito legal porque muda o olhar da gente, profissionalmente a gente mudou muito a forma de ver as coisas com o trabalho restaurativo(...) mudou muito mesmo, forma de abordar a pessoa, de abordar nosso trabalho, de encaminhar os casos, não se ver mais como o resolvedor do problema e sim encaminhador de soluções que são das partes e não nossa. (Promotor de justiça entrevistado)

Mais especificamente entre os operadores do Direito, a ideia é de que poderia haver uma relação de complementaridade entre os modelos retributivo e alternativo de maneira que o primeiro passasse a se beneficiar dos aspectos positivos que a justiça restaurativa traz, como por exemplo, esse olhar mais humano. Uma preocupação que fica bastante clara entre os redatores do relatório do ILANUD sobre os três programas-piloto, consultado para a pesquisa, é que a justiça restaurativa poderia colaborar para uma mudança na percepção das pessoas 
sobre aquilo que entendem como justiça em geral, ou mais especificamente o Judiciário e suas vias de acesso pela população, em especial a de baixa renda.

Nesse sentido, a justiça restaurativa poderia proporcionar uma mudança positiva, tendo em vista o alto grau de insatisfação dessa população com o modelo atual, ela poderia agregar ganhos na percepção destas pessoas por atentar para aspectos que ficaram "de lado", segundo o modelo oficial.

Essa atenção que se dá pra vítima ela é muito importante e isso traz de volta aquela sensação, pra vítima, de que a justiça foi feita e a justiça tradicional nem sempre cumpre essas necessidades mesmo que a pena seja cumprida seja executada, certamente como está previsto. (Promotora de justiça entrevistada)

O principal ponto, nesse caso, se refere à participação da vítima que se viu excluída do processo, desde que o Estado assumiu a função de repressão ao ato contrário à lei.

Sobre isso Zehr (2012) afirma que:

\footnotetext{
"A justiça restaurativa vê o crime primordialmente como um dano causado a pessoas e a comunidades. Nosso sistema jurídico, com seu foco em regras e leis e sua visão de que o Estado é a vítima, muitas vezes perde de vista essa realidade. Preocupado em dar aos ofensores o que eles merecem, o sistema jurídico considera as vítimas, na melhor das hipóteses, como preocupação secundária do processo penal" (ZEHR, 2012, p.34).
}

As declarações dos profissionais ouvidos pela pesquisa mostram como as representações que se tem sobre a justiça restaurativa são sempre construídas numa oposição ao modelo de justiça comum, sobre o qual a visão é geralmente crítica, por vezes negativa.

Vimos anteriormente como em parte isso é resultado de parcela da literatura a respeito do tema. Os primeiros autores a tratarem do tema da justiça restaurativa a definiam em oposição ao modelo de justiça comum definido como um modelo retributivo, contrário à proposta da justiça restaurativa entendida como um modelo essencialmente restaurativo.

Além do mais, ficarão evidentes ao longo do texto os contrastes existentes entre o que os profissionais reportam acerca do modelo e as práticas restaurativas observadas pela pesquisa. 


\title{
2.2 AS DISPUTAS EM JOGO
}

Cumpre destacar também as diversas implicações que essa vertente alternativa vinculada à justiça restaurativa apresenta no espaço das relações entre os profissionais, especialmente aqueles pertencentes ao mundo do Direito. A utilização, nesse caso, da expressão "mundo do Direito", baseia-se no entendimento que Bonelli manifesta no artigo $A$ competição profissional no mundo do Direito, onde a autora identifica um espaço social comum entre estes profissionais:

\begin{abstract}
A concepção de que elas (as profissões) formam um sistema baseia-se no desenvolvimento prático da atividade profissional, nas áreas de fronteira que possuem e no objeto que tem em comum que é a justiça, embora lidem com ela sob perspectivas diferentes. Essas relações originadas em decorrência do trabalho, neste campo, configuram o que chamaremos de 'mundo do Direito'. (BONELLI, 1998, p. 186)
\end{abstract}

Pedroso (2001) afirma que o debate quanto à ideologia dos modelos não adversariais de composição de conflitos cria nesse espaço um campo de práticas e saberes em desenvolvimento. Nesse sentido, seria preciso lembrar ainda que a importação de modelos institucionais e ideologias pode servir a diversas estratégias de legitimação e profissionalização de grupos ou elites profissionais (Badie apud Engelmann, 2006). Não é diferente em relação ao campo que se criou em nosso país em torno do modelo da justiça restaurativa, como será possível verificar.

Acerca das disputas no mundo do Direito, e mais especificamente no que diz respeito àqueles ligados à agenda da justiça restaurativa, um interlocutor vinculado à Comunicação Não Violenta ${ }^{42}$ expressou um argumento bastante interessante, ele diz: “Tem sido muito difícil para eles (juízes), então eles estão dentro de um ambiente em que muitas pessoas nao vêem do jeito que eles vêem, eles são muito radicais dentro do meio deles, mas eles não são muito radicais dentro do mundo da justiça restaurativa".

Esta fala é bastante significativa, uma vez que atenta para as relações que se estabelecem entre os profisisonais do Direito envolvidos com o modelo alternativo e seus pares. Sobressaem-se nesse contexto, especificamente, as divergências entre os juizes, já que

\footnotetext{
42 A Comunicação Não Violenta pode ser tida como uma técnica desenvolvida por Marshall Rosenberg, que visa o estabelecimento de uma comunicação entre pessoas, grupos ou entidades menos violenta e mais efetiva. Aqui no Brasil Dominic Barter é seu maior representante e teve participação fundamental na inauguração dos programas de justiça restaurativa no país.
} 
foram eles que lideraram as primeiras iniciativas no país, emboram existam outros pontos de tensão entre diferentes segmentos profissionais da área.

Estes profissionais, ligados à agenda da justiça restaurativa, que se situam numa posição mais heterodoxa da profissão, estão rompendo com alguns pressupostos internalizados em suas formações no Direito, mas, como o entrevistado relata, ainda não são suficientemente radicais do ponto de vista da justiça restaurativa. Essa situação cria ambiguidades que se refletem na própria dinâmica dos programas. Algumas das críticas às iniciativas feitas por avaliadores, e que este texto endossa, apontam para como os programas estão ainda fortemente vinculados à justiça oficial e dependem, em princípio, da própria avaliação que o magistrado faz do caso, para que seja ou não encaminhado ao círculo restaurativo. Em vista disso, existe também uma extensa discussão sobre se os valores do paradigma restaurativo estariam sendo seguidos fielmente nas regiões em que são aplicados, pois existiriam algumas adequações dos programas, advindas da mescla feita em relação aos tipos de justiça alternativa e oficial.

O mesmo entrevistado ainda discorre sobre a competição que presenciou entre juízes:

(...) eu era a única pessoa que passava entre os projetos, a dinâmica de concorrência entre os juízes era cômica, mas era muito extremo assim, tinha cenas que assim ninguém iria acreditar (...) ele (um juiz) era o único que conseguiu manter a calma, os outros dois (juízes)...: 'o que que o outro tá fazendo? O que tá acontecendo?

Como se afirmou anteriormente, os programas são ainda muito vinculados aos profissionais que organizaram a sua criação, o que em grande medida são os juizes, e a questão que aparece, nesse caso, é a maior vulnerabilidade desses profissionais conforme aumentam as suas responsabilidades e visibilidade. Destaca-se, portanto, o receio de algo sair errado com os programas e isso prejudicar suas carreiras ${ }^{43}$, ou suas reputações profissionais, o que é uma dimensão importante para estes profissionais. Outra consequência desta liderança, assumida por um grupo específico, é a grande dependência que se cria entre o programa e seus principais idealizadores:

Eu vejo uma coisa muito personalizada, você não fala do projeto da Segunda Vara de Execução de Medidas Sócio-Educativas de Porto

\footnotetext{
${ }^{43}$ Esse tipo de conhecimento pode ser entendido como uma espécie de tecnologia que demanda mais risco em tomadas de decisão. Para explorar mais o conceito ver a produção dos autores Beck e Giddens: BECK, U. Risk society. Towards a new modernity. Londres: Sage Publications, 1992 [1986]. 260p. GIDDENS, A; LASH, S. Reflexive modernization. Politics, traditions and aesthetics in the modern social order. Cambridge: Polity Press, 1994. 225p.
} 
Alegre; o projeto é do Doutor (nome do juiz) eu não falo do projeto da Vara da Infância e Juventude de São Caetano, o nome do projeto: (nome do juiz), eu não falo do Juizado Especial Cível, eu falo do projeto do (nome do juiz) e do promotor cujo nome me escapa agora. Então o receio evidentemente é que com a remoção, enfim, com a saída desses juízes desses locais o projeto não tenha prosseguimento.

A preocupação deste entrevistado tem fundamento, já que, como foi possível observar, o maior obstáculo para a continuidade dos programas é o deslocamento de seus principais envolvidos. Os programas saem prejudicados pela alta rotatividade dos profissionais que se deslocam em suas carreiras. Assim, sem maiores incentivadores no local, os programas acabam por se enfraquecer e se extinguem. Entre os profissionais do Direito, foi possível notar como muitos se impulsionaram na carreira a partir de seu envolvimento com a pauta da justiça restaurativa.

Assim, mesmo constituindo-se em uma pauta marginal dentro do mundo do Direito, foi possível observar a partir das entrevistas realizadas que muitos profissionais efetivamente se beneficiaram de suas ligações com a questão, o que possibilitou que galgassem novas posições em seus campos de atuação. Essa situação também demonstra como usualmente não é a justiça restaurativa aquela que alcança novas dimensões, mas sim aqueles que estão nas redes apoiando-a.

Já no contexto das escolas, os interlocutores relataram que os constantes processos de municipalização e transferência de professores interferem no trabalho de justiça restaurativa nestes locais, que fica descontinuado. De acordo com eles, muitos professores passam por uma capacitação, mas, logo em seguida, são transferidos de unidade e a escola vai perdendo o conteúdo aprendido. Uma interlocutora que participou do programa na região de Heliópolis disse que ela e uma colega chegaram até mesmo a montar uma sala no Conselho Tutelar da região para realizar os círculos restaurativos. Mas, segundo seu depoimento, cada vez que saíam do local desmontavam sua sala, de modo que sempre que retornavam tinham de recomeçar "do zero".

Também é preciso considerar que existe certa dificuldade para lidar com um conteúdo que diverge enormemente de tudo aquilo que foi estudado, interiorizado pelos profissionais da área jurídica, algo já incorporado em sua vida profissional, pessoal, na postura e opiniões. Parece haver, portanto, um conflito nos profissionais que participam da proposta que vem do fato dela abalar convicções sobre justiça que estão arraigadas nesses personagens, que vêm desde a sua formação profissional até o trabalho atual. Nenhum dos entrevistados se dedica somente à justiça restaurativa, eles efetivamente têm que lidar com duas vertentes diversas. 
Existe uma divergência entre os ideários que se revela na dificuldade de sustentar o conteúdo e nas pequenas interações do dia a dia, nas "piadinhas" entre colegas. A respeito desta questão, um juiz de São Paulo afirma:

(...) nas lideranças educacionais, na pessoa que está na escola, é responsável pela implementação do projeto tem que capacitar elas pra lidar com esse tipo de situação, e entender, é tudo, né, uma piada que se faz de você, já falaram, eu sou "restaurador de dente", quer dizer, ou vai abraçar árvore, daqui a pouco você está abraçando árvore tudo isso você tem, então como você lida com isso? Numa boa, mas pra lidar numa boa e tem que ser, quer dizer ótimo que seja numa boa, mas já é um teste pra você aí no seu projeto de vida (Juiz da capital).

Fica claro, portanto, como a estratégia dos pares de desqualificar seguidamente aquele profissional envolvido com a questão ("restaurador de dente", "está abraçando árvore" "está passando a mão na cabeça do aluno") vem no sentido de apontar como não há, na verdade, expertise em jogo. Essa foi uma maneira encontrada de se colocar contrariamente a pauta: questionando-a, colocando-a sob suspeita.

Novamente este magistrado em nova entrevista reafirmou sua posição:

Como é que você capacita elas pra que elas efetivamente tenham o mínimo de condição de ser um agente de mudança insitucional e isso passa por como é que elas vão lidar com as resistências, porque virão e virão, e já ter consciência disso, olha vai ter contramovimento, refluxo de toda ordem, é piadinha no corredor, que tá abraçando árvore, que tá não sei o quê, tá acreditando em duende, ou você tá recebendo alguma coisa com isso, ah! mais um projeto da secretaria que vem de cima pra baixo...

Mas ainda isso?

Muito, muito, mas é muito, muito, muito. Aquela coisa toda, que tá passando a mão na cabeça de aluno, tudo isso...

As chacotas entre os colegas indicam que os profissionais mais ortodoxos da profissão questionam se há expertise em jogo em relação à justiça restaurativa como uma forma de se oporem à pauta; é possível questionar, entretanto, em que medida isso não acaba sendo confirmado pelos próprios juízes que estão aplicando o modelo alternativo visto que eles próprios têm delegado os casos considerados de menor potencial ofensivo para os novos facilitadores de justiça restaurativa. Essa postura, longe de fortalecer o modelo, só vêm a reforçar sua marginalidade em relação à justiça oficial. 
Ao mesmo tempo, é importante ressaltar também que estes juízes já originalmente trabalham em um ramo da justiça visto por muitos colegas de profissão como menos prestigioso. Ali não são aplicadas as teorias convencionais da pena, e desde a criação do Estatudo da Criança e do Adolescente o caráter pedagógico das sanções dirigidas às crianças e aos adolescentes foi reforçado, em detrimento da punição como originalmente concebida e aplicada na justiça para adultos, devido ao fato de se tratarem de indíduos ainda em formação.

Estes magistrados da área da justiça voltada às crianças e adolescentes são, portanto, duplamente marginalizados no mundo do Direito. Primeiro por atuarem na área da infância e juventude, segundo por se vincularem à justiça restaurativa. Infere-se que seja, este portanto, o motivo que levou um colega de profissão a proferir a frase à um dos entrevistados: "(você) tá passando a mão em cabeça de aluno", como relatado por um juiz em uma entrevista.

Halliday (1999) afirma ainda, a respeito das carreiras no Direito, que a consolidação da autonomia profissional deu-se, nesse caso, pelo estabelecimento de uma neutralidade técnica do conhecimento, o que cria no mundo profissional uma espécie de ortodoxia em relação a qual se contrapõe uma heterodoxia, representada pela postura profissional que aproxima o conhecimento específico de ações políticas.

Nesse sentido, o conceito de profissionalismo, desenvolvido por autores do campo da sociologia das profissões, pode contribuir para o entendimento a respeito das relações, muitas vezes conflituosas, que se estabelecem entre os profissionais do mundo do Direito, especialmente no que concerne ao tema da justiça restaurativa.

Freidson é um autor que afirma desenvolver um “(...) tipo ideal que denomino profissionalismo e, a partir dele, analiso os órgãos e recursos exigidos para que ele se estabeleça. Trato o tipo ideal como um conjunto constante de características e os órgãos e recursos como variáveis que interagem" (FREIDSON, 1996, p.142). Em seu livro, o autor constrói uma visão weberiana do profissionalismo, como um tipo ideal, a fim de entregá-lo para o debate no qual ficaria exposto à crítica e à revisão podendo servir para dar foco e objetividade aos demais estudos empíricos.

Em sua obra Profissionalism: The Third Logic, Freidson expõe que as profissões têm uma lógica interna diferente tanto da lógica que rege o mercado (onde supostamente reina a escolha racional do consumidor) quanto da lógica burocrática que atua através do governo ou das empresas.

O profissionalismo pode ser caracterizado, sinteticamente, como uma forma específica de se exercer uma ocupação e de estabelecer relações no mundo do trabalho, construída 
historicamente. Ele valoriza o conhecimento abstrato, a formação em cursos superiores, a autonomia profissional, entre outras características. (BONELLI, 2003; FREIDSON, 2001). Além disso, representa um tipo alternativo aos modelos burocrático e de mercado, a partir da qual é ressaltada a neutralidade da expertise.

Sobre o profissionalismo, Bonelli (2008) destaca ainda as suas 4 principais conceituações: o tecnocrático, o cívico, o democrático e o organizacional. Os autores Olson \& Dzur (2004) analisam a justiça restaurativa a partir de um olhar da sociologia das profissões, dentro do tipo de profissionalismo democrático. Elas acreditam que os profissionais têm papel primordial no aumento da participação democrática popular em assuntos públicos:

\footnotetext{
Uma teoria de profissionalismo democrático sugere considerar uma zona alternativa entre o controle total tanto pelo Estado quanto comunidade em que ambos enriqueçam a teoria da justiça restaurativa e respondam às críticas de justiça informal. (...) Num nível mais prático, acreditamos que o profissionalismo democrático caracteriza o que muitos profissionais de justiça restaurativa estão fazendo: reprofissionalizando em direção a uma prática mais democrática (OLSON , DZUR, 2004:153).
}

Este é um exemplo de análise que foca nos potenciais efeitos positivos que iniciativas ligadas à justiça restaurativa podem trazer. Esses agentes de justiça alternativos operam e fornecem justiça em nível micro, não são representantes formais da autoridade, ainda que estejam ligados a instituições estatais, no mínimo, por credenciais (SLAKMON; OXHORN, 2005). Isso estaria levando a uma prática mais democrática do exercício de administração de conflitos, devolvendo essa capacidade de gestão da conflituosidade para a comunidade.

\subsection{A ESTRATÉGIA DAS DIFERENTES DEFINIÇÕES}

Durante todo o processo de pesquisa, pude observar diferentes definições de justiça restaurativa entre meus interlocutores. Isso, é claro, se reporta ao fato de o próprio modelo não ter uma definição única, como discutido no primeiro capítulo, mas não é só isso. É possível questionar em que medida as diferentes conceituações sobre a justiça restaurativa não deixam de ser também formas encontradas pelos agentes para resistirem, fazerem oposição, se defenderem, ou seja, é também uma forma de agência destes indivíduos.

Para ilustrar o argumento que será desenvolvido, segue o excerto de uma entrevista, em que facilitadoras do município de São José dos Campos (SP) falam sobre esta questão: 
Uma vez conversando com a ..., ela falou pra gente, eu não esqueço essa fala dela, ela falou assim: 'às vezes você não precisa nomear, ah, o que eu to fazendo é justiça restaurativa, você pode simplesmente propor uma atividade, fazer uma intervenção, fazer alguma coisa' e depois assim, ah, como foi bom, como foi gostoso, então! Isso é justiça.

De acordo com esta entrevistada, justiça restaurativa pode ser muitas coisas. Essa questão da terminologia a respeito do modelo foi um ponto que emergiu durante o trabalho de campo. Durante as incursões em campo, observei o emprego de uma gama de conceitos; alguns dos termos utilizados são: justiça restaurativa, círculos restaurativos, ações restaurativas, atendimentos restaurativos e os envolvidos com os programas, ora os utilizam em alguns momentos como se fossem todos termos sinônimos e em outras vezes como se se tratassem de coisas completamente diferentes. Como poderemos observar em um dos círculos restaurativos a ser descrito no terceirto capítulo da tese, uma facilitadora chega a definir aos alunos justiça restaurativa como um programa do governo.

Dentre os entrevistados envolvidos na aplicação do modelo alternativo no estado de São Paulo, pude notar algumas falas em comum que relacionavam a justiça restaurativa à noção de justiça enquanto um "valor". Ao fazerem isso, estes agentes tornam difícil a tarefa daqueles que estudam os programas de afirmarem em que lugares há e em que lugares não há mais justiça restaurativa. Isso porque se o argumento mobilizado pelos profissionais é o de que a justiça restaurativa é justiça enquanto um valor, algo que transcende a sua mera aplicação prática, então muito embora em alguns lugares não exista mais a prática dos círculos, eles podem argumentar que o modelo teria permanecido de alguma forma, pois os profissionais já teriam sido sensibilizados e deve ter havido, portanto, uma mudança de "mentalidade", de modo que a essência da justiça restaurativa não se perdeu. Isto abre uma ampla margem para aqueles responsáveis pela difusão do modelo no país afirmarem que seus trabalhos tiveram continuidade, mesmo que todas as evidências indiquem o contrário:

Algumas pessoas dizem, ah, não continua acontecendo nas escolas todas que vocês trabalharam. A pergunta é: 'não continua acontecendo o que? O círculo? Talvez o círculo não, pode ser que não, pode ser que as pessoas que tenham aprendido aquela técnica elas não estejam mais, a gente tem uma rotatividade muito grande do professor numa escola que vai pra outra, o serviço público de um modo geral, não é só nas escolas, as pessoas são remanejadas, elas são colocadas pra fazer outras funções, isto pode acontecer, é verdade. A minha pergunta é, vai na escola ver se não tem aqueles princípios trabalhados que orientam a convivência de uma outra maneira. O impacto na questão 
do regimento escolar, eu to usando a escola como um exemplo, elementos que ajudem esta convivência a ser menos punitiva, vai ver se o número de advertências diminuiu. Se isto acontece, eu vou te dizer que ali continua acontecendo justiça restaurativa na perspectiva que a ONG trabalha (Profissional entrevistada que realiza capacitações)

Do mesmo modo, quando questionada sobre se o programa em Heliópolis prossegue ou não, outra entrevistada argumenta: "Olha, assim formalmente não, tem ninguém fazendo círculos na comunidade, mas o que ficou foi a prática restaurativa e a cultura de paz né”.

Não é tarefa deste trabalho avaliar em que lugares há justiça restaurativa e em que lugares não, de acordo com o que a teoria sobre o modelo nos diz, mas antes mostrar em que medida isso é característico do campo. Os atores estão movimentando este mesmo campo, pois o tempo todo são negociados os sentidos atribuídos ao modelo e as legitimidades de quem pode e quem não pode dizer o que é a justiça restaurativa.

Mais que denotar uma confusão de sentidos para o termo, esse quadro indica as diversas estratégias que são empregadas pelos profissionais. Como dito anteriormente, uma destas estratégias é justamente a utilização de uma noção vaga para o termo, de modo que não se possa contestar o argumento de que o programa continua, mesmo que a prática cotidiana mostre o contrário.

Outra possibilidade interpretativa para o caso é que os entrevistados estão, dessa forma, demarcando uma fronteira de saber, ou seja, a pesquisadora ainda não compreendeu o que é justiça restaurativa. É muito comum a sensação, durante a realização das entrevistas, de que meus interlocutores querem me ensinar o que é a justiça restaurativa, pois, de acordo com a avaliação que fazem de mim e das perguntas que apresento, eu ainda não sei ou não entendi o que é o modelo restaurativo.

$\mathrm{Eu}$ penso que pra eu poder te ajudar eu realmente acho que eu tenho que contar um pouco de como é que a ONG trabalha com justiça restaurativa. Porque é aquilo que eu tava falando antes de começar a gravar né, eu acho muito temeroso e me preocupa muito, muito, quando as pessoas dizem, e eu escuto isso com frequência, ah a justiça restaurativa não deu certo, ela não continua acontecendo. Eu acho isso sério no sentido de que você vai botando um rótulo, em alguma coisa, o que é muito difícil a gente tirar, então eu acho que o primeiro cuidado que eu peço às pessoas, que estão se aproximando dessa área, que não estão no campo realizando, que é diferente né, que tenham o cuidado com esse tipo de informação, porque eu acho que acaba sendo um desserviço pro processo de uma mudança de paradigma, que é o que a justiça restaurativa traz pra gente (Profissional entrevistada que realiza capacitações) 
Sobressai deste trecho transcrito o momento em que a entrevistada diz: “ (...) eu peço as pessoas, que estão se aproximando dessa área, que não estão no campo realizando, que é diferente né (...)"; nesse momento, ela marca uma divisão entre os que estão empenhados na implementação do modelo, ou, em suas palavras, os que estão no campo realizando e os outros, categoria dentro da qual ela me insere e que, não estando preocupados com a aplicação prática, acabam muitas vezes prestando um desserviço ao dizerem que programas se extinguiram em alguns locais.

Como pontuei em trabalho anterior ${ }^{44}$, o manuseio de diferentes significações sobre o termo é uma forma de agência destes indivíduos, muitas vezes utilizada para amparar o discurso de sucesso que se quer atestar, outras vezes como forma de resistência, ou ainda como oposição.

Ao analisar durante meu mestrado a situação no município de São Carlos (SP), localidade em que a ideia de implantação de um programa de justiça restaurativa não foi emcampada, foi possível verificar como a negociação de significados, um conceito-chave da vertente sociológica do interacionismo simbólico, era uma forma de resistência localizada entre os agentes.

O conceito sociológico de negociação de significados está embasado na noção de que os homens formam, sustentam e transformam os objetos de seus mundos conforme atribuem significados a eles. Esta é uma das premissas do interacionismo simbólico, uma vertente da chamada microssociologia que prima por focalizar as interações entre os indivíduos. Estes objetos ou mundos são comumente tidos como dados prontos, mas deveriam, segundo Blumer (1969) ser analisados como frutos de criações sociais, como surgidos a partir de um processo constante e dinâmico de definição/redefinição e interpretação/reinterpretação que os indivíduos promovem constantemente.

Blumer foi um autor importante para constituição do interacionismo simbólico. Este autor teve parte de sua obra dedicada a fundamentar esse segmento sociológico. Ele discorre sobre as bases do interacionismo dialogando mais especificamente com a psicologia social e autores como Mead. Para Blumer, são três os principais pontos que sustentam a vertente: o primeiro ponto é a noção de que os homens agem sobre os objetos de acordo com o significado que estes objetos têm para ele; nesse sentido, cabe ressaltar que esses objetos

\footnotetext{
${ }^{44}$ Internacionalização do saber jurídico e redes profissionais locais: um estudo sobre justiça restaurativa em São Carlos (SP) e São Caetano do Sul (SP). TONCHE, Juliana. Dissertação de mestrado apresentada ao PPGS da UFScar, 2010.
} 
podem se referir a coisas, pessoas, instituições, redes ou outras referências de análise. O segundo ponto se reporta ao fato de que o significado das "coisas" deriva, por sua vez, da interação social. Já o terceiro ponto, este diz que esses significados são negociados, modificados, a partir de um processo interpretativo.

Blumer argumenta que, embora estas premissas possam, à primeira vista, parecer um tanto óbvias, grande parte dos estudos ignora esses dados, o que torna essas análises de certa forma incompletas. Segundo ele, seria preciso ter em mente que a interação social acontece predominantemente no plano simbólico e que os significados não são dados prontos, eles são, antes, produtos sociais.

O interacionismo simbólico nos alude, portanto, para o fato de que os seres humanos não reagem simplesmente às ações uns dos outros, mas eles são definidos, ou definem as ações dos outros, através de um processo de construção/interpretação. Além do mais, cabe ressaltar que este processo só ocorre porque existe um acordo de significados atribuídos a determinados objetos, de maneira que todo processo de interação também é resultado de um processo semelhante anterior que acontece internamente aos seres, isto é, entre o ser e o self, como já começava a indicar Mead.

Blumer já apontava como os homens na interação uns com os outros levam em conta o que o outro está fazendo ou vai fazer de maneira que eles são levados a direcionar sua própria conduta ou negociar sua situação de acordo com os termos em comum. Existe também uma interação que ocorre entre o próprio ser e seu self de modo que são diversas variáveis agindo: o que se espera do outro, o que pensa de si mesmo; logo, a inter-relação e a conduta individual são formadas no e por este processo dual, de entender e se fazer entender.

Segundo Blumer: "Uma rede ou instituição não funciona automaticamente devido a algumas dinâmicas internas ou requisitos do sistema; ela funciona porque pessoas de diferentes pontos fazem algo, e o que fazem é resultado de como elas definem a situação na qual são chamadas a agir" (BLUMER, 1969, p.19). Diante de situações de mudanças sociais seria mais prudente reconhecer, segundo este autor, que elas acontecem mediadas pelas unidades de ação interpretando as situações com que se deparam.

Dessa forma, o conceito de negociação de significados aplicado à questão da vinda da agenda global da justiça restaurativa para uma localidade contribuiu para o desenvolvimento desta análise, pois parte-se da premissa de que as pessoas constroem ${ }^{45}$, individualmente e

\footnotetext{
${ }^{45}$ Encontramos essa questão em autores como Becker (BECKER, Howard S. Uma Teoria da Ação Coletiva. Rio de Janeiro: Zahar, 1977. 225p.) e Goffman. (GOFFMAN, Erving. A representação do eu na vida cotidiana. Rio de Janeiro: Petrópolis, $13^{\mathrm{a} e d}$. Editora Vozes, 2003. 233p.).
} 
coletivamente, ações através da interpretação das situações com que são confrontadas. Os estudos de caso realizados no mestrado e doutorado e a análise dos discursos dos entrevistados permitiu verificar em que medida as diferentes interpretações de justiça restaurativa pelos indivíduos são também formas de agência e não de sujeição, que podem ser traduzidas em resistência velada (caso enbcontrado na cidade de São Carlos).

No contexto de recusa ao modelo restaurativo pelo município de São Carlos, analisado durante o mestrado, foram encontrados dentre os entrevistados diversas opiniões a respeito do que seria a justiça restaurativa. Alguns se aproximaram mais dos usos correntes, outros se afastaram mais e um entrevistado desconhecia o modelo. Interessante notar que para o promotor da área na cidade, a justiça restaurativa se aproximava muito daquele trabalho que ele já desenvolvia na cidade e aponta que somente dessa forma seria bem vinda:

Se você entender como justiça restaurativa, aquela justiça que vem a restaurar uma situação natural, onde aquilo devia estar acontecendo, quer dizer o seio familiar é o principal, então acho que de repente a justiça restaurativa a gente pode estar mudando de nome e falando de apoio familiar (...). Eu acho que seria bem-vindo, eu acho que, aí, mas assim, focando a questão familiar tá? (Promotor da área da Infância e Juventude de São Carlos).

Essa forma de interpretação conforma a justiça restaurativa a um sentido distinto daquele conteúdo como foi originalmente concebido. Esse manuseio de significados é uma forma de resistência velada, por permitir o aumento da diluição da proposta na localidade. Nesse sentido, quanto mais distante mais a negociação de significados a respeito da justiça restaurativa a afasta do perfil original. Esta é, portanto, uma forma de resistir à agenda alternativa.

De maneira diversa, nos contextos analisados durante o doutorado, locais que já acolheram iniciativas de justiça restaurativa ou nos quais ainda existem programas, a diluição da proposta pela manipulação de significados serve a outro propósito. Não objetiva resistir à agenda da justiça restaurativa, mas sim resistir às crescentes críticas com as quais tem tido de enfrentar: por parte dos pesquisadores, avaliadores, professores ou a própria população que é atendida pelos programas.

Assim, as situações encontradas nos diferentes contextos relativos à implantação ou não da justiça restaurativa possibilitam constatar em que medida as diferentes interpretações do modelo, elaboradas pelos indivíduos, são formas estratégicas, que podem ser traduzidas em 
resistência velada, ou, ao contrário, utilizadas para reforçar um discurso de sucesso, tentando driblar as críticas que surgem.

Resultante destas disputas em torno da conceituação sobre justiça restaurativa também é o fato de que as críticas, as vozes dissonantes, são sempre encaradas pelos meus interlocutores como falta de conhecimento. Os críticos só seriam críticos do modelo porque ainda não conhecem mais sobre a justiça restaurativa, mas, de acordo com suas opiniões, quando passarem a conhecer, serão a favor também:

Olha, pelas pessoas que participaram do círculo, eu posso te dizer que não foram muitas aqui eu participei assim foi 100 por cento de aprovação, essa dúvida existe por quem ainda não passou pelo grupo de estudos, ainda não conhece.

Ela falou assim ontem 'é uma incoerência você vir falar de facilitador, porque você não sabe o que é facilitador, vocês estão inclusive usando o termo errado, é mediador', então eu não quis abordá-la, a gente estava num café, (...) essa profissional provavelmente ela inda não leu, ainda não conhece (Capacitadora entrevistada).

Estas dissonâncias em torno das definições do modelo ficam bastante nítidas inclusive nas situações de entrevistas. Em praticamente todas elas os interlocutores tentam explicar o que é a justiça restaurativa de acordo com suas opiniões e em geral gostam de ilustrar seus argumentos relatando casos que marcaram suas experiências com o modelo.

Este foi um dado interessante que emergiu do campo. É frequente a sensação de que eu estou desapontando o(a) entrevistado(a), porque aquilo que eu quero saber normalmente não é o que eles querem contar e vice-versa. Foi preciso repensar as estratégias para a condução das entrevistas, pois os interlocutores em geral queriam relatar somente como a justiça restaurativa é inovadora, transformadora, querem contar suas experiências com o modelo numa tentativa de talvez me "converter" também.

Em uma entrevista com uma das organizadoras da iniciativa em São José dos Campos, no interior de São Paulo, cheguei a ser questionada sobre minha opinião em relação ao que estava ouvindo sobre o programa na localidade. A princípio fiquei surpresa e foi quando a entrevistada me explicou, mostrando-se preocupada, que já que eu tinha tido contato com outras iniciativas na região, ela gostaria de saber minha opinião sobre o trabalho que eles estavam fazendo ali, no sentido de que eu pudesse fazer alguma avaliação. Este é mais um indicativo de como a justiça restaurativa tem criado um campo no qual os programas e profissionais rivalizam também. 
Cabe destacar também que as dissonâncias em torno do conceito da justiça restaurativa e a postura de tomar as vozes críticas como falta de conhecimento não apareceram somente em entrevistas com profissionais envolvidos diretamente na aplicação do modelo. O mesmo acontece em eventos acadêmicos, como foi possível observar. Assim, muitos outorgam a si a capacidade de saber definir o que é justiça restaurativa, mas se recusam a fazê-lo, já que isso poderia ferir seu caráter alternativo, informal e progressista, ao mesmo tempo em que as críticas são interpretadas como falta de compreensão. Essa tem sido, basicamente, a dinâmica das discussões a respeito deste modelo alternativo de gestão de conflitos.

\subsection{O MERCADO DAS CAPACITAÇÕES}

Em todos os eventos assistidos sobre o tema das novas formas alternativas de administração de conflitos, esta questão é sempre lembrada: a de que o Judiciário vive uma crise e que os conflitos precisam ser resolvidos numa outra instância, para que a instituição não fique ainda mais sobrecarregada.

Como veremos no próximo capítulo, esse é o principal objetivo que orienta a inauguração desses projetos e programas de justiça restaurativa no país, especialmente aqueles do estado de São Paulo, abordados pela pesquisa.

Além disso, o tema bastante atual dos números alarmantes de encarceramento no Brasil, especialmente no estado de São Paulo, é sempre lembrado nestes eventos ${ }^{46}$. O argumento defendido é o de que a justiça restaurativa poderia contribuir para estacionar e talvez até mesmo reverter as tendências estatísticas de encarceramento, que apontam sempre para o crescimento da população encarcerada e crescimento do número de presídios construídos para abrigar essa população.

Este contexto é curioso, pois como coloca Hallsworth (2012), estamos presenciando um movimento de retorno à antigas práticas, reforço punitivo ao mesmo tempo em que verificamos iniciativas de reabilitação, penas alternativas. Portanto, é preciso pensar que as novas formas de penas alternativas e as novas formas de alternativas de gestão de conflitos surgem concomitantes a um aumento no número de encarcerados e de clamor popular por penas mais “duras”, situação aparentemente ambígua.

\footnotetext{
${ }^{46}$ O número de presos no Brasil chegou a 715. 655 em 2014; com isso o país entra em terceiro lugar no ranking dos países de maior população carcerária, ficando atrás somente dos Eua e China. São Paulo é o estado com o maior número de presos do Brasil, são 204. 946 (Dados do CNJ, 2014).
} 
Nikolas Rose (2000) também argumenta que propostas que enfatizam a necessidade de indivíduos e comunidades se tornarem mais responsáveis por sua própria segurança coexistem com argumentos a respeito do endurecimento das penas e crescimento do número de encarcerados.

A situação, entretanto, longe de ser contraditória é bastante coerente, se nos lembrarmos dos autores que discutem o surgimento dessas iniciativas de justiça no sentido de verificar como elas podem colaborar para um reforço punitivo, já que, além de serem mais uma forma de controle social e punição, retiram dos meios oficiais conflitos de menor potencial ofensivo, deixando para que a justiça oficial se ocupe dos casos considerados pelos operadores do Direito como realmente importantes, sobre os quais as penas da lei serão mais duras.

Como parte da realização do trabalho de campo, participei de alguns destes eventos que visam impulsionar os novos modelos alternativos de gestão de conflitos, dentre eles a justiça restaurativa. A maioria deles, entretanto, invariavelmente discute a mediação. Ainda que ela não faça parte do escopo desta pesquisa, estamos falando de alternativas concorrenciais num campo disputado e atravessado por diversos segmentos profissionais. Além disso, tratam-se muitas vezes dos mesmos interlocutores. Os mesmos grupos responsáveis pelas capacitações em justiça restaurativa realizam, também, capacitações de mediadores e conciliadores. O problema, nesse caso, é que não raras vezes tratam os diversos modelos como se fossem a mesma coisa.

Faget (2004) aponta que o surgimento da mediação estimula uma competição quase mercadológica no campo da profissionalização e da legitimidade na administração de conflitos. Ele descreve ainda que o desenvolvimento do conjunto de formas alternativas de administração de conflitos abre um novo mercado, embora nem sempre a mediação seja alternativa, bem como a participação de cidadãos voluntários ou de profissionais de áreas não jurídicas nem sempre signifique uma ruptura com a lógica vigente.

Um dado importante é que o Instituto Mediativa, e mais especificamente o grupo Justiça em Círculo, realiza um programa de capacitação de mediadores (alguns de alto custo) em que o indivíduo mediante o pagamento de um valor, que pode ser parcelado, tem direito a um período de capacitação teórica e prática. Durante a parte teórica do curso o inscrito cumpre horas e participa de diversos workshops e cursos.

Depois desta fase, começa o período de estágio supervisionado, em que o inscrito conduzirá mediações na prática. $\mathrm{O}$ fato de alguns deste grupos de capacitação conseguirem alocar essas pessoas em um estágio no fórum é um grande atrativo para o curso. Isso 
acontece, segundo os participantes relataram durante um curso, porque quando as pessoas fazem este estágio no fórum conseguem o registro de mediador, um tipo de certificado, e a partir disso podem abrir seus próprios escritórios particulares de mediação.

Um exemplo deste fluxo foi um ex-empresário presente num dos workshops assistidos, que disse claramente estar participando para conseguir seu certificado de estágio em um fórum, para seguir uma carreira de mediador de conflitos em empresas.

Em entrevista uma das sócias do Mediativa, disse:

A gente veio como voluntária trabalhar aqui na promotoria e aí o promotor vendo o trabalho, tantos anos né, desde 2005 isso, trabalhando como voluntária, fazendo mediação e ele acredita muito na mediação, ele pediu que a gente desse uma palestra pros promotores lá no prédio do ministério público mesmo, (...) e aí eles gostaram muito da palestra de mediação e aí deu pra lançar o curso lá no ministério público e gente deu dois anos, vai sair o terceiro ano de curso no ministério público (...), é aberto ao público e eu já vou te falar é o curso mais em conta que tem, e não é que é pior ou melhor que outro. (...) O curso é de um ano, são 80 horas de teórico e 80 de prática (...) é o curso que tá mais barato do mercado, eu to falando porque eu dou aula no Mediativa, dou aula no ministério público, a gente tem um curso que a gente abriu uma empresa e começou a dar cursinho pra lidar com conflitos do dia a dia, não era nem curso, eram encontros e tal que a gente dava recurso pra lidar com os conflitos do dia a dia, depois disso a gente começou a ser chamada pra capacitação em ONGs pelo contato que a gente tinha com a prefeitura então foi enveredando por esse caminho. Então a empresa que nós temos (...) e a gente também dá curso, de mediação, teórico e o prático é feito aqui no ministério público.

Esta fala mostra as estreitas relações que se estabelecem entre os grupos que promovem as capacitações e instituições como o Ministério Público. Além disso, de acordo com seu relato, foi o contato com a Prefeitura que possibilitou a ampliação do escopo de trabalho e passaram a realizar capacitações em diversas ONGs e municípios.

Esta mesma interlocutora foi quem primeiro utilizou a expressão "mercado" para definir o espaço no qual estas práticas estão sendo institucionalizadas. Quando questionada sobre a participação de mediadoras no workshop sobre justiça restaurativa, ela diz que estavam lá: "Pra começar a conhecer essa nova coisa que tá entrando aí no mercado, né".

De acordo com seu depoimento, e como corroborado pela observação participante, inaugurou-se um nicho para a capacitação de profissionais das mais diversas áreas, para que possam aprender a lidar com os conflitos do dia-a-dia (termo utilizado neste meio). Mais um excerto da entevista permite entrever como funciona o processo de divulgação do curso: 
$\mathrm{Na}$ coordenadoria de Assistência Social, da região sudoeste vai ter uma palestra de justiça restaurativa, pra acho que 30, não sei se são 30 pessoas ou se são 30 serviços, ligados ao menor em conflito com a lei pra levar uma palestra pra que esses serviços contratem capacitação pros seus funcionários.

É importante destacar, também, que além deste grupo chamado Mediativa, existem outros que realizam o mesmo trabalho, como a ONG CECIP, sediada no Rio de Janeiro, que participou da inauguração dos primeiros projetos de justiça restaurativa no país e que continua a realizar capacitações e consultorias para novos programas que surgem, nos mais diversos estados. De acordo com uma entrevistada, participante da iniciativa de São José dos Campos, existem dissonâncias entre os grupos, a princípio por questões metodológicas, que resultaram numa divisão das localidades dentro das quais cada grupo poderia atuar:

Pra nós as contribuições foram muito grandes dos dois lados, são ONGS que a gente consegue trabalhar de maneira participativa, não temos dificuldade nisso, eles ouvem a todo o momento as nossas considerações, os nossos pedidos, mas eles tiveram algumas divergências metodológicas durante este percurso, os dois, entre eles, até fora daqui e eles redividiram o trabalho que eles tinham assumido juntos, teve lugares que o Mediativa assumiu e teve lugares que o CECIP assumiu. (...) Como o contrato nosso era do CECIP, o Mediativa estava por um acordo entre eles, então ficou o CECIP, provavelmente há contratos em que o mediativa tinha assinado e que deve ter ficado com o Mediativa, eles redividiram (Integrante do programa em São José dos Campos entrevistada).

De acordo com um dos projetos de implantação de justiça restaurativa em uma localidade do estado de São Paulo a que obtive acesso, o CECIP - Centro de Criação de Imagem Popular, fundado em 1986, é descrito como uma organização da sociedade civil sem fins lucrativos, que visa democratizar o acesso de amplas camadas da população a informações qualificadas, buscando, deste modo, construir uma sociedade consciente, ativa e participativa. O CECIP completou, em 2006, 20 anos de existência, tendo realizado nesse período em torno de 80 projetos, abordando os temas: jovens e comunicação, saúde de crianças e adolescentes, direitos de cidadania, educação infantil, equidade de gêneros, meio ambiente, entre outros.

Sua missão, de acordo com o material consultado, seria contribuir para o fortalecimento da cidadania e para definição de políticas públicas que promovam direitos humanos - econômicos, sociais, culturais, políticos e ambientais. Atuando nas áreas de 
educação e comunicação, o CECIP concebe e realiza produções audivisuais, publicações, formação de agentes de mudança e campanhas sociais em respostas a demandas da sociedade.

Já o Mediativa - Instituto de Mediação Transformativa, foi constituído em 11 de novembro de 2007, tendo como associados fundadores 63 mediadores. De acordo com as informações disponíveis no site (http://www.mediativa.org.br/ acessado em 03/02/15) a instituição, sem fins lucrativos, tem como objetivos, definidos em seu estatuto:

1.) pesquisar, desenvolver, divulgar, capacitar e implementar métodos para resolução alternativa de conflitos;

2.) fornecer à comunidade informações, produtos e serviços relacionados aos métodos para resolução alternativa de conflitos;

3.) prestar serviços a pessoas físicas e jurídicas, públicas ou privadas, concernentes aos métodos alternativos de resolução de conflitos.

Todos os associados do Mediativa são mediadores, cuja formação segue os parâmetros mínimos definidos pelo FONAME. Na verdade, o site da organização afirma que o Mediativa faz parte do FONAME - Fórum Nacional de Mediação, criado em 2007, integrando o grupo de entidades que se dedicam ao aperfeiçoamento, à divulgação e à prática da mediação de conflitos.

Estes duas organizações estão empenhadas na divulgação e implantação do modelo da justiça restaurativa pelo país na medida em que são, em grande parte das vezes, os grupos responsáveis pelas capacitações dos futuros gestores e profissionais que irão atuar nestes programas. Estes grupos vão até os locais onde se pretende instalar um programa, a partir de financiamentos que conseguem obter para as primeiras capacitações, mas a falta de um acompanhamento sistemático dos programas, que se baseiam no voluntarismo dos envolvidos cotidianamente nos programas, contando com pouca ou quase nenhuma estrutura, acaba por determinar seu futuro.

Especificamente do Mediativa criou-se ainda um sub-grupo chamado Justiça em Círculo. Este grupo, formado por mediadoras participantes do Mediativa especializou-se na atuação sobre o modelo específico da justiça restaurativa.

A seguir alguns exemplos dos folders das capacitações, promovidos por estes grupos: 

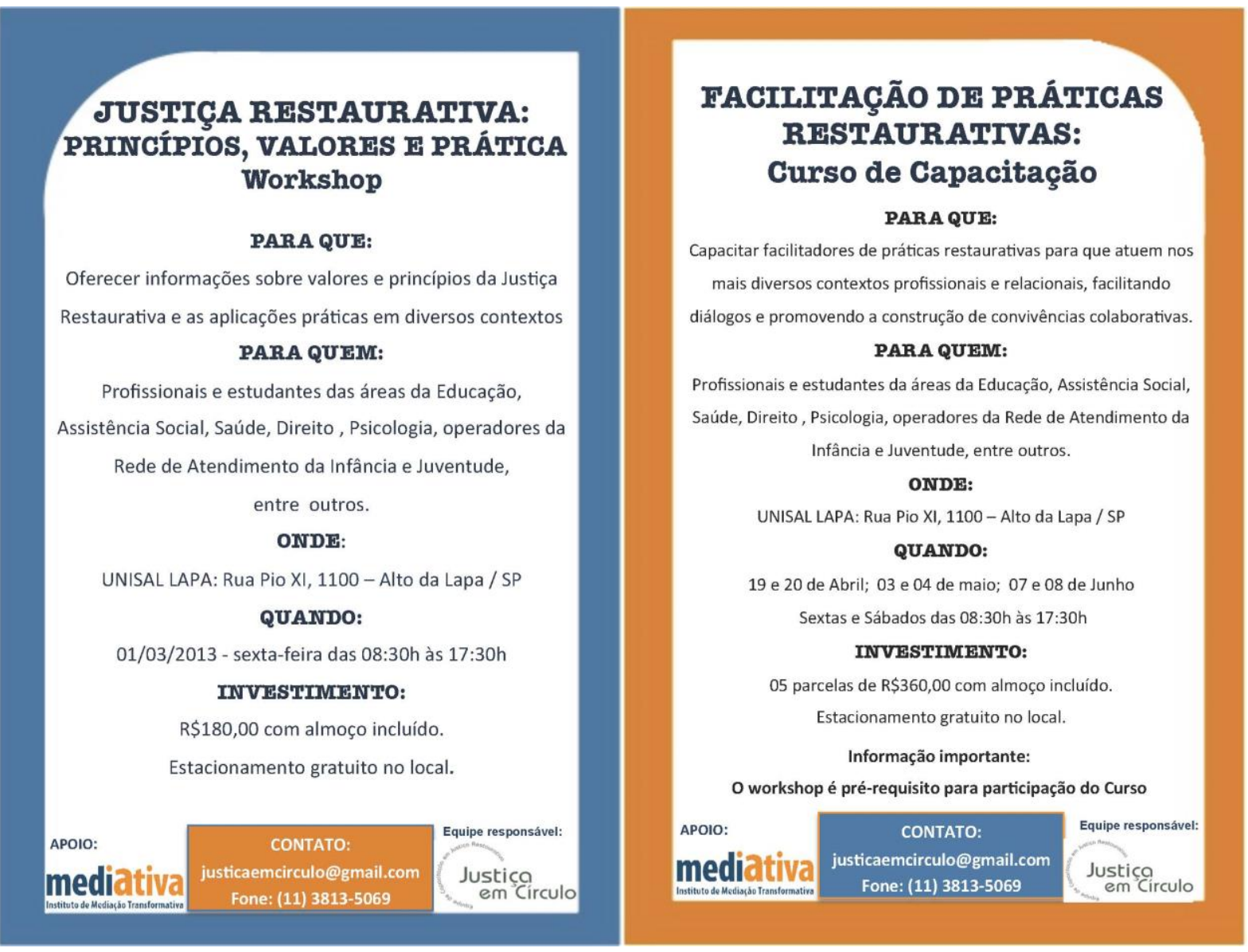


\section{Workshop "LIDERANÇA RESTAURATIVA" com Belinda Hopkins \\ Coordenação Equipe Justiça em Círculo}

"Conceitos restaurativos centrais serão exemplificados através de atividades em pares e em grupos incluindo vários formatos de processos circulares"

\section{Data: 26 de setembro de 2014 (sexta-feira)}

Local: UNISAL LAPA - Rua Pio XI, 1100 - Alto da Lapa - SP

Horário: das $08: 30$ hs às $17: 30$ hs

Informações e inscrições com Isabel 11 3813-5069

Entre no site e preencha o formulário de inscrição - garanta sua vaga! clique aqui

$$
\begin{array}{cc}
\text { Investimento: } & R \$ 300,00 \\
\text { Sócios do Mediativa: } & R \$ 270,00 \\
\text { Almoço incluído } &
\end{array}
$$

Estacionamento gratuito no local
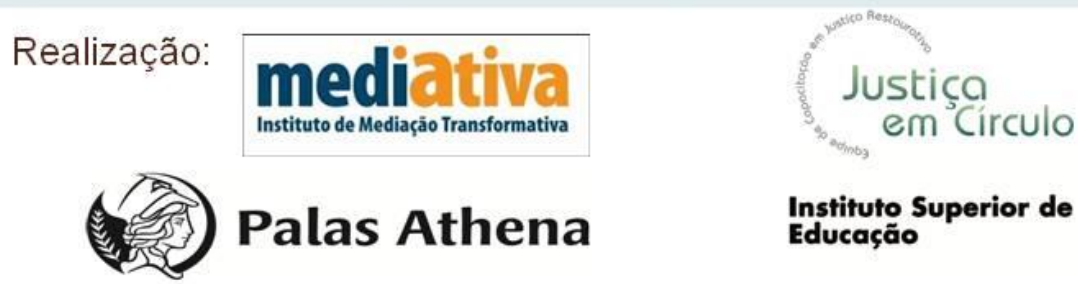

Instituto Superior de Educação

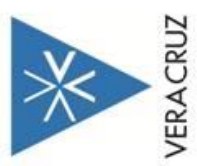




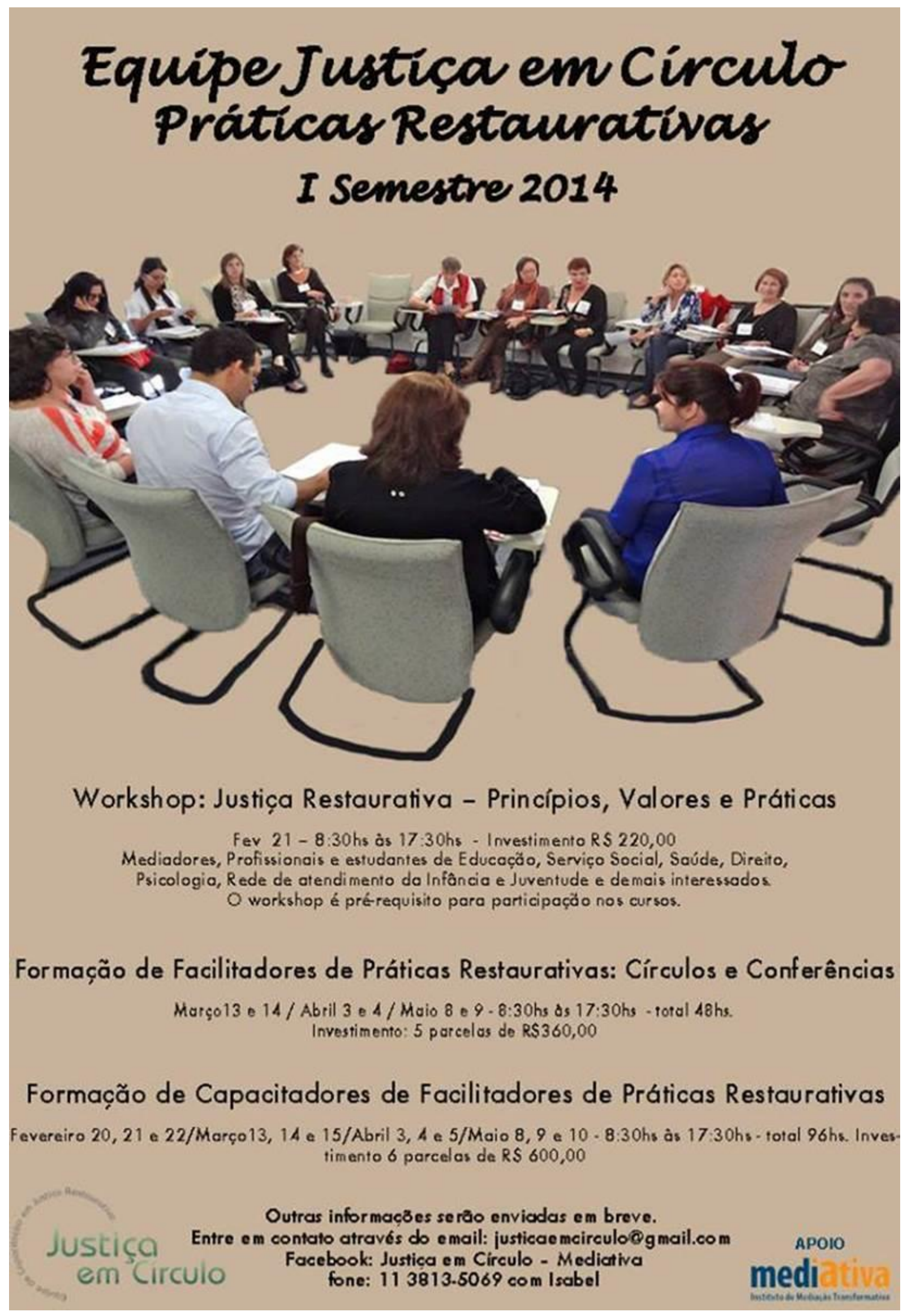




\section{PRÁTICAS RESTAURATIVAS NAS ESCOLAS segundo Belinda Hopkins}

\section{Curso}

Para profissionais da educação e promoção social que trabalham com crianças, adolescentes e adultos no contexto de relações.

Data: 18 e 19 de outubro

$08: 30$ às $17: 30 \mathrm{~h}$

Local: Rua Cardoso de Almeida $634-1^{\circ}$ andar São Paulo

\section{Responsabilidade docente: \\ Monica Burg, Sueli Renberge Violeta Daou}

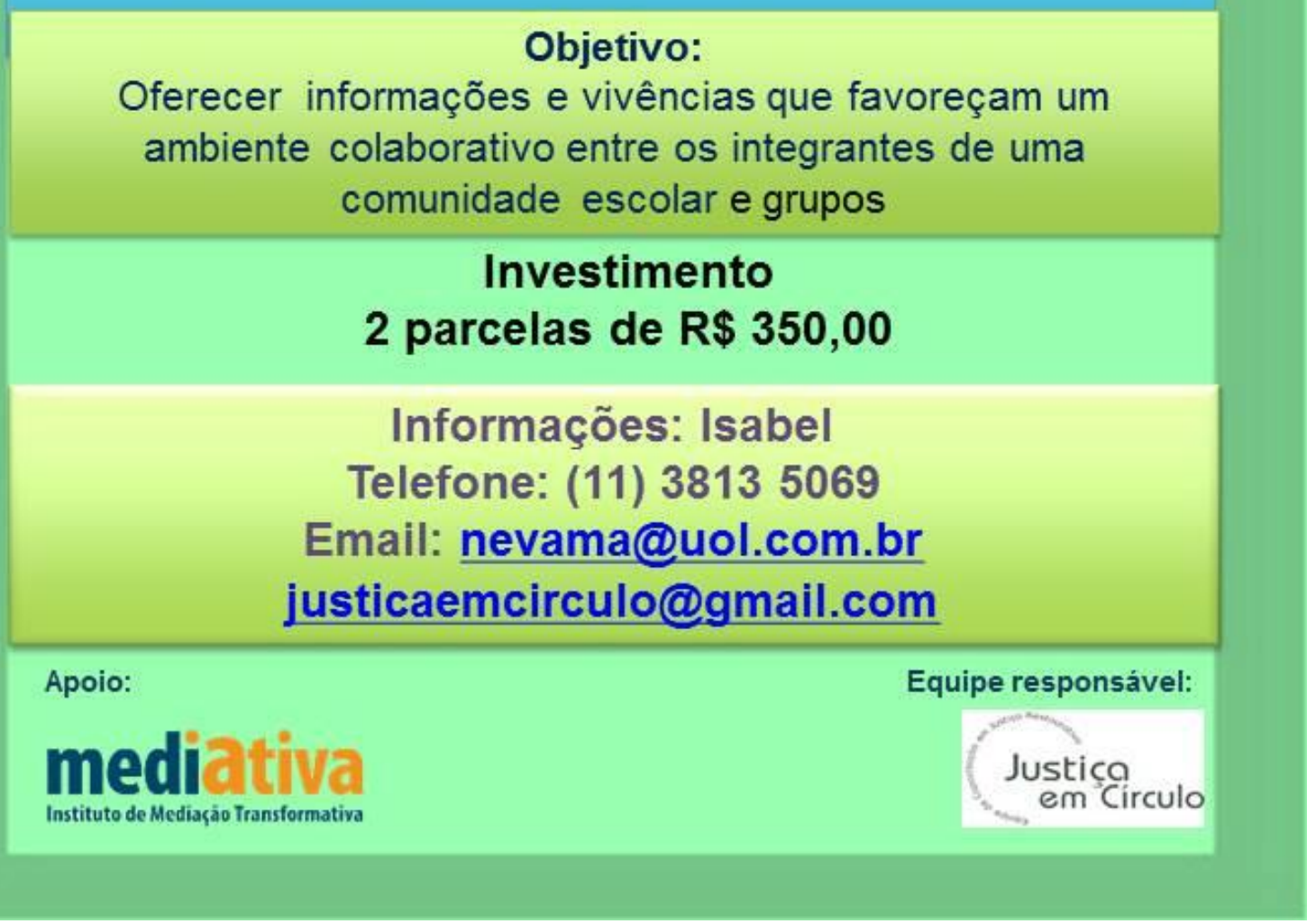


PRÁTICAS RESTAURATIVAS curso intensivo de férias

\section{Públicoalvo}

docentes, gestores de escolas, psicólogos, assistentes sociais, pedagogos, educadores, operadores de Direito e de Justiça, dirigentes comunitários, agentes de segurança.

Data: de 19 a 5 de julho

Local: Rua Cardoso de Almeida 634 - 12 andar SP $08: 30$ as $16: 30 \mathrm{~h}$

Responsabilidade docente:

Celia Bernardes, Mara Melo e Vania Yazbek Pela equipe Justiça em Círulo, licenciada pelos institutos internacionais:

IIRP - International Institutefor Restorative Practices

ILAPR - Instituto Latino Americano de Practicas Restaurativas

Conteúdo temático:

- Introdução às Práticas Restaurativas

- Facilitação de Círculos Restaurativos

- Coordenação de Reuniões Restaurativas

Investimento:

2 parcelas de $R \$ 370,00$ (junho-julho) Incluso: 03 livros como base didática

Informações: Isabel

Telefone: (11) 38135069

Email: nevama@uol.com.br justicaemcirculo@gmail.com

APOIO:
Institut de Mediasio Trastormation

\section{REUNIÕES DE GRUPO FAMILIAR}

curso intensivo

para educadores, integrantes da área técnica dos fóruns

(psicólogos e assistentes sociais), agentes de saúde, integrantes de CAPS, CRAS, CREAS, dirigentes comunitários.

\section{Data: 5 e 6 de agosto}

Local: Rua Cardoso de Almeida 634 - 12 andar SP $08: 30$ as $17: 30 \mathrm{~h}$

Responsabilidade docente: Jean Schmitz

Facilitador e Capacitador

ILAPR - Instituto Latipo Americano de Practicas Restaurativas IIRP-International Institute for Restorative Practices

\section{Conteúdo temático:}

- Visãogeral da reunião degrupo familiar.

- Exercícios práticos de reuniões de grupo familiar.

- Discussão sobre a filosofia da prática.

- Vídeo sobre a reunião de grupo familiar baseado em situações reais e membros da familia que vivenciaram reunião do grupo familiar.

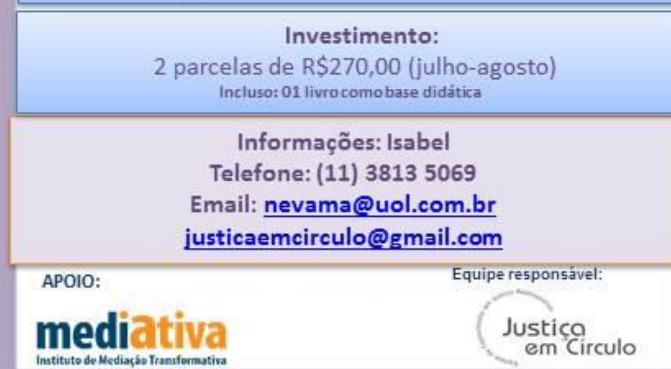




\section{FORMAÇÃO EM MEDIAÇÃO TRANSFORMATIVA} REFLEXIVA

\section{$\checkmark$ Módulo Teórico \\ $\checkmark$ Dia 07 de agosto de 2014 \\ $\checkmark$ Quinta feira das $18 \mathrm{~h} 30$ às $22 \mathrm{~h} 00$}

Equipe docente multidisciplinar

Treinamento baseado em competências autocompositivas

LOCAL $\rightarrow$ Rua Cardoso de Almeida, 634 - 10 andar - Perdizes - estacionamento no local.

INFORMAÇÕES $\rightarrow$ administrativo@mediativa.org.br ou

11946741786 (Eduardo) 11996596042 (Mathias) 11988810656 (Monica)

O Mediativa é entidade credenciada pelo Tribunal de Justiça de São Paulo

e o curso atende aos requisitos da Resolução 125 do CNJ.

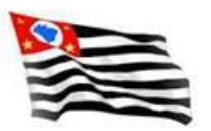




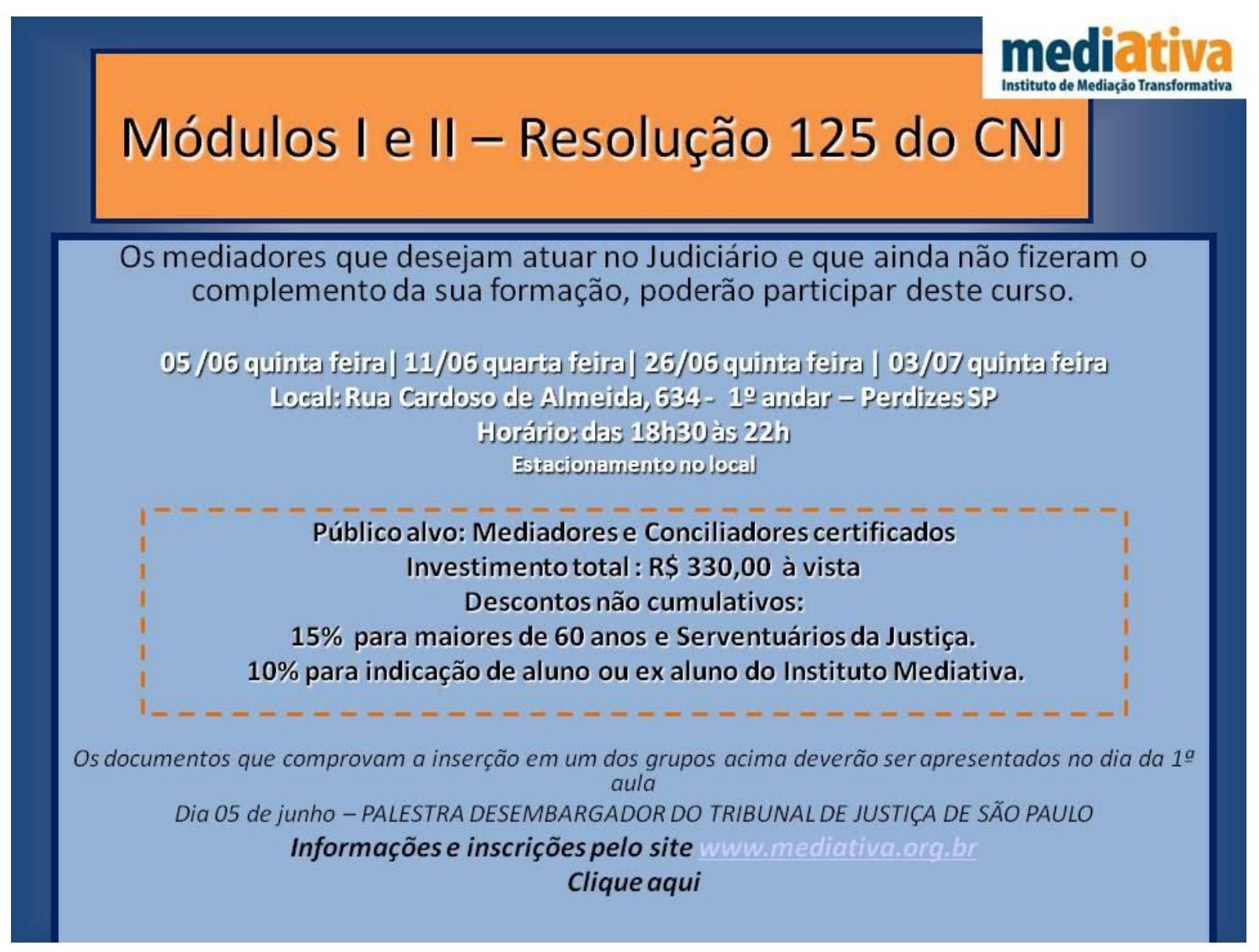




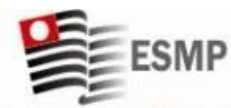

$4^{\circ}$ Curso de Extensão Universitária

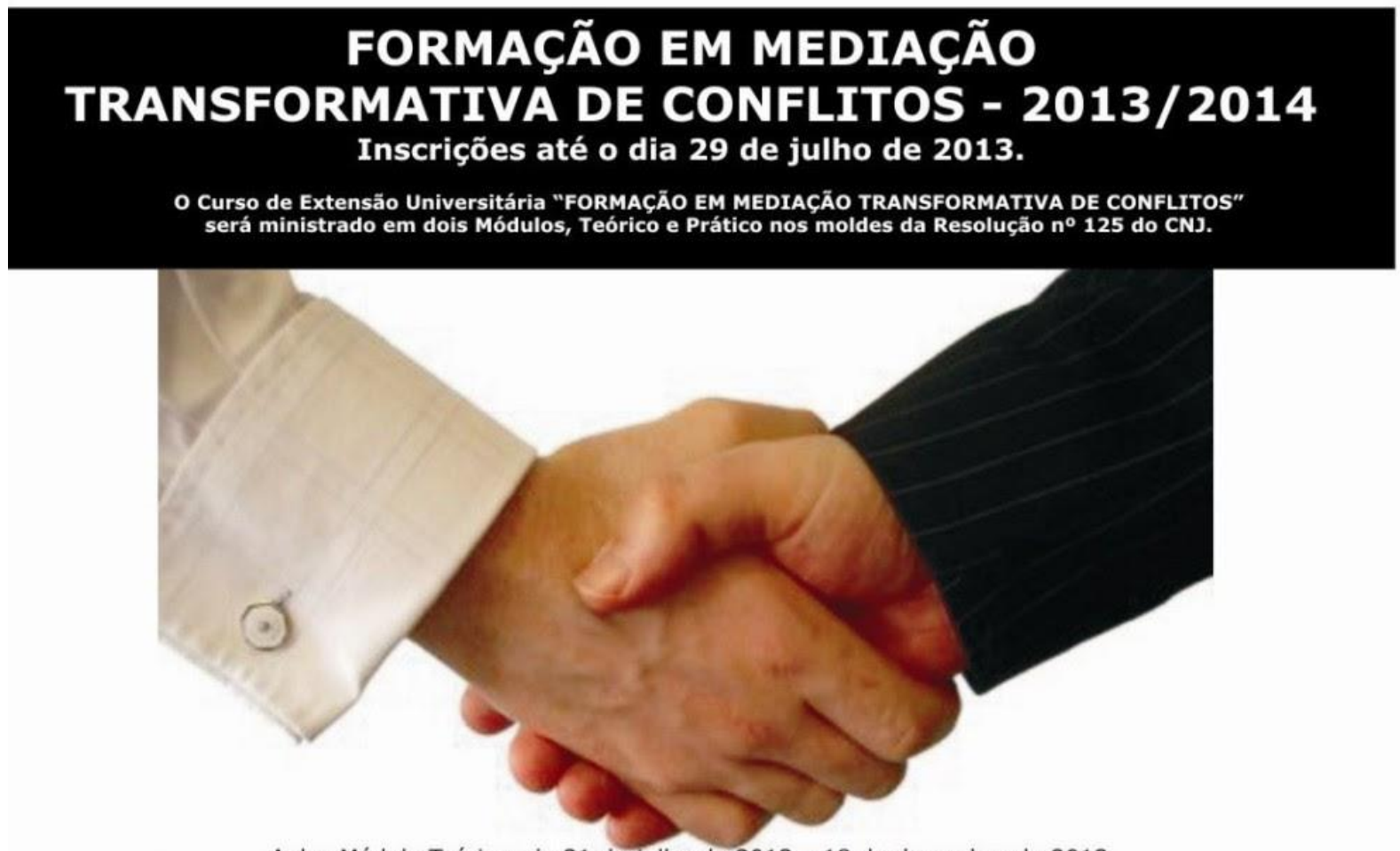

Aulas Módulo Teórico: de 31 de julho de 2013 a 18 de dezembro de 2013.

ESMP - Rua Treze de Maio, n.1259 - $2^{\circ}$ andar - Bela Vista (SP)

Aulas Módulo Prático: de fevereiro de 2014 a julho de 2014.

Aulas práticas nas instalações da Promotoria de Justiça Criminal de Santana.

72 vagas, preenchidas mediante ordem cronológica de inscrição.

Para informações sobre valores e condições, consulte o edital no site da ESMP: www.esmp.sp.gov.br.

O curso de Extensão Universitária "Formação em Mediaçăo Transformativa de Conflitos" tem como finalidade formar Mediadores, oferecendo embasamento teórico e vivencial para análise e manejo transformativo dos conflitos (Mediação Transformativa).

Público Alvo: Profissionais de todas as áreas do conhecimento que necessitem intervir para facilitar o diálogo nas diferentes situaç̄es de conflito, em especial, Operadores do Direito, Psicólogos, Educadores, Psiquiatras, Assistentes Sociais, Administradores, Consultores nas Empresas, Estudantes Universitários e pessoas interessadas na Formação e Mediação de conflitos e no desenvolvimento de posturas mediadoras.

Mais informações pelos telefones (11) 3017-7782/7783/7744 e pelo e-mail esmp-secretaria@mp.sp.gov.br.

Realização:

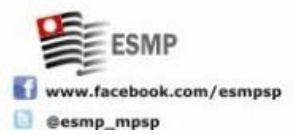

Coordenação Geral: Procurador de Justiça - Diretor do CEAF-ESMP
Apoio Cultural:

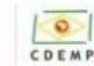




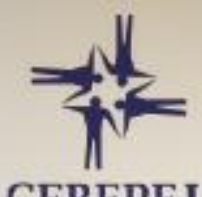

FONAME

CEBEPEJ

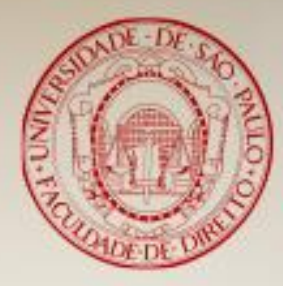

FADUSP - FACULDADE DE DIREITO DA UNIVERSIDADE DE SÃO PAULO FONAME - Fórum Nacional de Mediaçâo

CEBEPEJ - Centro Brasileiro de Estudos e Pesquisas Judiciais

convidam para o SEMINÁRIO

MÉTODOS CONSENSUAIS
DE SOLUÇÃAO DE CONFLITOS: RUMOS DA RESOLUÇÃO 125 do CNJ 27 AGO $2012 \cdot 08 \mathrm{H} 30$ ÀS $18 \mathrm{H} 30$ SALÃO NOBRE DA FACULDADE DE DIREITO DA USP • LARGO SÃO FRANCISCO

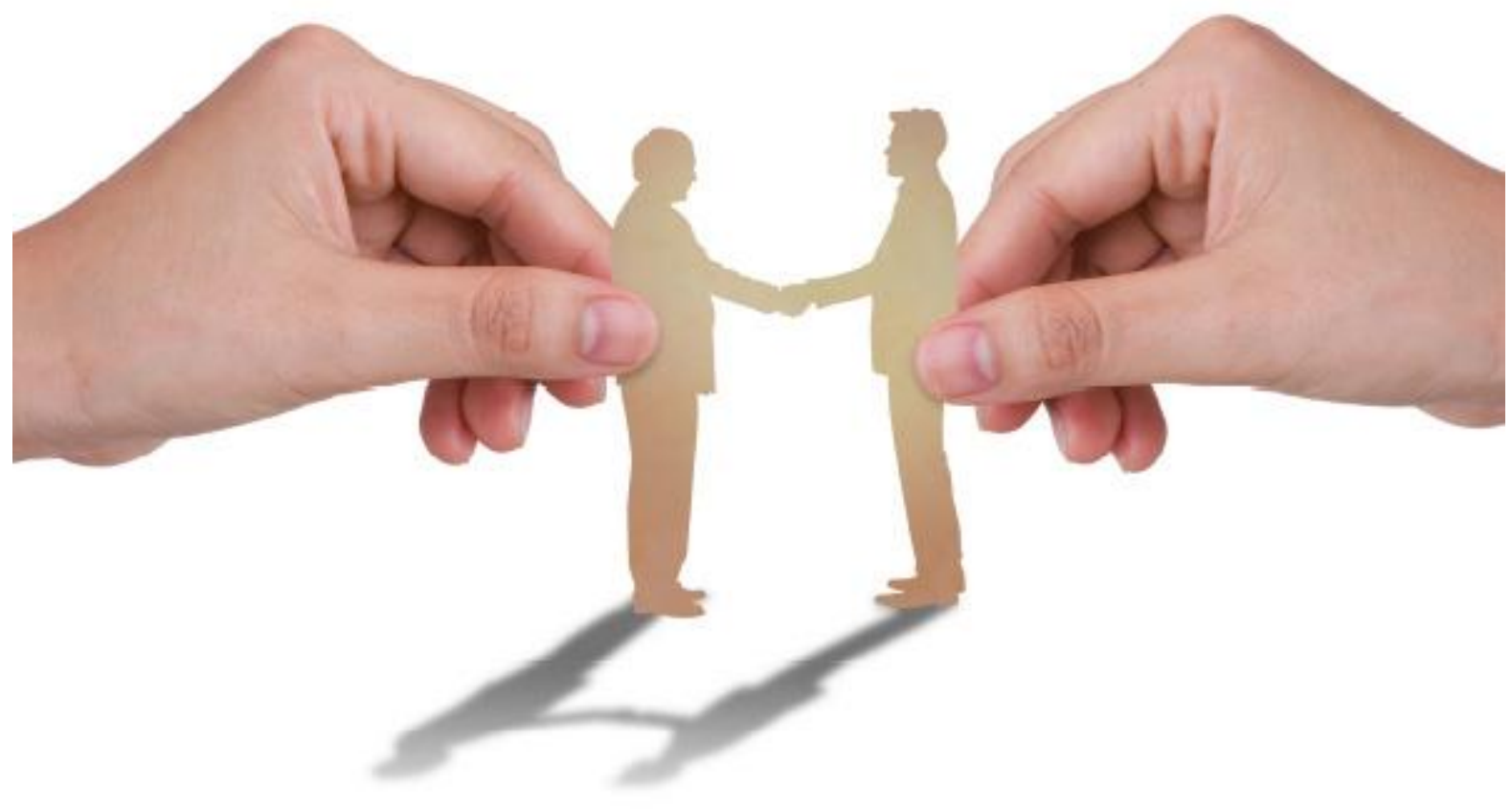


É provável que esteja havendo nesse campo das capacitações um processo de profissionalização em curso. Segundo Freidson (2001), a profissionalização pode ser definida como um processo no qual uma ocupação (organizada formalmente ou não, através da reivindicação das suas competências especiais, da qualidade particular de seu trabalho e dos benefícios que assim proporcionaria para a sociedade) obtém o direito exclusivo de realizar um determinado tipo de trabalho, além de obter controle sobre a formação e acesso e o direito de determinar e avaliar a forma como esse trabalho é realizado.

Em relação aos facilitadores de justiça que trabalham como voluntários nos programas, temos a informação de que não é preciso ser um profissional do meio jurídico para exercer a função de mediador, ou facilitador de justiça, neste caso específico. Teoricamente qualquer membro da comunidade pode ser um facilitador caso se comprometa com a causa e frequente os cursos de capacitação.

São Caetano do Sul contou com mediadores (ou facilitadores) que são aposentados, jornalistas, agentes de saúde entre outros profissionais. Integrantes do projeto e seus idealizadores eventualmente realizam, na cidade, workshops e eventos procurando divulgar o projeto, seus bons resultados e os benefícios que a justiça restaurativa traz, tentando, dessa forma, angariar novos possíveis facilitadores. Nos dois workshops que tive a oportunidade de participar, realizados no início de 2008, foram feitas dinâmicas em grupo com o objetivo de mostrar os aspectos positivos da justiça restaurativa em comparação ao meio oficial de resposta aos conflitos e os integrantes do projeto também tem, nesse momento, a oportunidade de relatar suas experiências pessoais; eles contam, em geral, como a justiça restaurativa proporcionou um sentimento de realização em suas vidas e alguns relatos são até emocionados. Ao final de um dos workshops em especial, todos os presentes foram impelidos a preencher um papel no qual demarcavam como seria sua participação no projeto, se seriam facilitadores, encaminhadores, ou outros. Momentos nos quais ficava particularmente constrangida, por estar participando como estudante e não como alguém que potencialmente viria a trabalhar nos programas. 
CAPITULO 3:

\section{OS CÍRCULOS RESTAURATIVOS}




\subsection{O PROGRAMA EM SÃO CAETANO DO SUL}

São Caetano do Sul é um município brasileiro do estado de São Paulo, localizado na mesorregião metropolitana de São Paulo e microrregião de São Paulo. É conurbado com as cidades de São Paulo, assim como Santo André e São Bernardo do Campo, fazendo que se percam os limites físicos entre estes municípios - chamados de ABC paulista.

De acordo com os dados do IBGE do último recenseamento, realizado em 2010, São Caetano do Sul possuia 149.263 habitantes. As estimativas mais atuais, apontam que município deve contar hoje com aproximadamente 157.205 habitantes ${ }^{47}$ em uma área de 15 quilômetros quadrados.

Seu Índice de Desenvolvimento Humano (IDH) em 2010 era de $0,862^{48}$, considerado o melhor do país de acordo com o PNUD (Programa das Nações Unidas para o Desenvolvimento) e tem sido assim por três anos consecutivos. O IDHM médio das cidades brasileiras é de 0,727 , o que insere o país na faixa considerada de "alto desenvolvimento humano", que vai de 0,7 a 0,799, segundo o PNUD. Dessa maneira, São Caetano do Sul cidade é considerada uma cidade que apresenta "muito alto desenvolvimento humano", já que seus índices estão acima de 0,8 .

Mais alguns dados que ilustram os bons índices apresentados pelo município, fazendo que seja considerado um dos melhores do país: sua incidência de pobreza é de cerca de 12 , 18\%; a expectativa de vida ao nascer é de 78,2 anos e $76 \%$ da população adulta tem pelo menos o ensino médio completo.

O site da prefeitura municipal de São Caetano do Sul apresenta estes índices na seção da Secretaria de Desenvolvimento Econômico e Relações do Trabalho (www.investesaocaetano.com.br): "Há dez anos, São Caetano do Sul é o município com o melhor IDH do Brasil (PNUD/2010) e considerado exemplar em vários aspectos do IDH da ONU, estando em $1^{\circ}$ lugar na lista dos municípios brasileiros".

A cidade possui também o menor Índice de Exclusão Social do país $(0,864)$ e está entre os 60 municípios com o maior Índice de Desenvolvimento Infantil (0,895), de acordo com o Fundo das Nações Unidas para a Infância (Unicef). O município detém também a maior renda per capita da região do Grande $\mathrm{ABC}(\mathrm{R} \$ 70.367,00$ por ano) e segundo dados do

\footnotetext{
${ }^{47}$ Estimativas da população residente com data referência de $1^{\circ}$ de julho de 2014, publicadas no Diário Oficial da União em 28/08/2014 de acordo com o site do IBGE, acessado em novembro de 2014.

${ }^{48}$ Fonte: Atlas Brasil 2013 Programa das Nações Unidas para o Desenvolvimento. Disponível no site do IBGE, acessado em novembro de 2014
} 
IBGE, o Produto Interno Bruto (PIB) da cidade passou dos $\mathrm{R} \$$ 9,3 bilhões em 2006, colocando a cidade entre os 50 municípios mais ricos do País.

Além disso, a cidade também apresenta o segundo menor Índice de Vulnerabilidade Juvenil à Violência, segundo dados do Fórum Brasileiro de Segurança Pública ${ }^{49}$. São Caetano do Sul ficou em segundo lugar entre as cidades com menor Índice de Vulnerabilidade Juvenil (perdendo somente para São Carlos -SP) dentre todas as cidades brasileiras com mais de 100 mil habitantes.

Estes dados foram divulgados pelo Ministério da Justiça e pelo Fórum Brasileiro de Segurança Pública em novembro de 2009. A pesquisa, que ouviu jovens entre 12 a 29 anos em 266 cidades brasileiras, foi responsável pela criação do índice que mede a situação de vulnerabilidade dos jovens à violência. As capitais e as cidades brasileiras foram classificadas, portanto, de acordo com o índice apresentado. A cidade de São Carlos se situa em primeiro lugar com o menor índice, sendo seguida por São Caetano do Sul. Tendo as capitais como referência, se Maceió (AL) tem o maior índice de jovens expostos à violência, São Paulo fica no ranking como a de menor índice.

São Caetano do Sul é também um município do estado de São Paulo muito importante para aqueles que querem se dedicar ao tema da justiça restaurativa, pois foi instalado ali um dos três programas-piloto implantados, com o apoio da Secretaria da Reforma do Judiciário e PNUD, em 2005 no país. O foco deste programa é a área da infância e da juventude e integração com o sistema público educacional. Os outros dois programas-piloto se desenvolveram no Núcleo Bandeirante (Distrito Federal), mais especificamente no Juizado Especial Criminal, e Porto Alegre (Rio Grande do Sul) aplicado na Vara de Execuções de Medidas Sócio-Educativas na área da Infância e Juventude.

O programa de São Caetano do Sul foi o principal analisado pela presente pesquisa e todos os círculos restaurativos assistidos, e que serão descritos a seguir, aconteceram neste município.

Porém, mediante a realização do trabalho de campo, pude me atualizar também a respeito dos progressos em curso no programa de justiça restaurativa que se inicia no município de São José dos Campos-SP, ao passo em que verifiquei o contexto de desarticulação e enfraquecimento da pauta na cidade de Campinas-SP, local em que muito se investiu, apostando no sucesso da iniciativa, mas que não teve prosseguimento; o mesmo

\footnotetext{
${ }^{49}$ Sobre o índice de vulnerabilidade juvenil, de como foram construídos os parâmetros de construção e análise das variáveis/resultados, consultar: "Índice de Vulnerabilidade Juvenil à Violência". In: FÓRUM BRASILEIRO DE SEGURANÇA PÚBLICA. III Anuário do Fórum Brasileiro de Segurança Pública. São Paulo, 2009, pp. 5463.
} 
acontecendo com Heliópolis, em São Paulo (neste caso, diferentemente do que aconteceu em Campinas, que sequer começou a funcionar, o programa de Heliópolis funcionou por vários anos e definhou devido ao deslocamento de seus principais incentivadores).

Em vista disso, ainda que a pesquisa tenha se desenvolvido e abarcado outras regiões do estado de São Paulo, grande parte do texto está dedicado ao caso de São Caetano do Sul, por algumas razões. A primeira delas se deve ao fato deste programa ser o único no estado que funciona de maneira regular desde 2005; outra questão diz respeito ao fato de eu já ter acompanhando este programa desde o mestrado, o que além de proporcionar o acúmulo e aprofundamento de reflexões, facilitou o acesso e a inserção no campo, ainda que estas entradas ao pesquisador estejam bastante prejudicadas hoje.

Sobre o início do programa em São Caetano do Sul, foram divulgados dados bastantes $\operatorname{positivos}^{50}$. De acordo com Melo (2008), desde 2005, data que marca o início de suas atividades, até 2007, ou seja em apenas dois anos de projeto:

- Foram realizados 260 círculos restaurativos;

- Mais de 1.000 pessoas foram atendidas;

- Índices de acordo de $88 \%$;

- Destes $96 \%$ teriam sido cumpridos;

A Proposta de trabalho para os projetos de justiça restaurativa e comunitária de São Caetano do Sul em 2007 (Documento de 15/06/2007) a que tive acesso reforça estes dados:

"As experiências têm se mostrado absolutamente exitosas. Foram
mais de 600 pessoas atendidas em cerca de um ano e meio de projeto,
com índices de acordo de $98 \%$, dos quais $95 \%$ foram cumpridos. O
sucesso desta iniciativa ditou o financiamento, pela Secretaria de
Estado da Educação de São Paulo, com recursos do Ministério da

${ }^{50}$ O projeto do Rio Grande do Sul também divulgou resultados muito positivos: Entre 2005 e 2011, 11,793 pessoas participaram de atividades de sensibilização e formação promovidas diretamente pelo Justiça 21. Destas, 1,059 realizaram o Curso de Formação de Lideranças em Justiça Restaurativa promovido pela Escola Superior da Magistratura e 908 participaram do Curso de Formação de Coordenadores de Círculos Restaurativos. Um monitoramento feito pela Faculdade de Serviço Social da PUCRS acompanhou 380 casos atendidos no Juizado entre 2005 e 2007. Entrevistando os participantes, constatou-se que 95\% das vítimas e 90\% dos ofensores saíram satisfeitos de sua experiência de contato com a justiça após participarem de procedimentos restaurativos. (Os índices internacionais de satisfação no contato com a justiça criminal giram em torno de meros $12 \%$ a $15 \%$ positivos). Cerca de $90 \%$ dos acordos foram julgados cumpridos. A reiteração de atos infracionais entre os odensores participantes caiu em $23 \%$ comparativamente a outros que não participaram de nenhum encontro restaurativo (ZEHR, 2008, p.8). 
Educação, de dois projetos semelhantes aos de São Caetano do Sul, na capital do Estado e em Guarulhos, indicando o cárater referencial do projeto no país".

Estes números são referentes ao começo do programa, por isso procurei me informar sobre dados mais atuais e, de acordo com o coordenador do programa, não haviam sido sistematizados ainda. $\mathrm{O}$ fato de eu ter questionado sobre tais dados inviabilizou ainda mais minha inserção enquanto pesquisadora num campo já bastante adverso.

Assim, não apenas não temos informações sobre como esses dados foram produzidos, como tampouco sabemos a que se referem, por exemplo, quando dizem que os acordos foram feitos. O que é considerado acordo? Sob quais circunstâncias foram delineados?

Ademais, é evidente que com todos os excelentes índices que a cidade apresenta, deve existir uma pressão maior sobre todos os programas sociais e de políticas públicas encampados naquela região, para que sigam apresentando resultados satisfatórios. Isso não poderia ser diferente com o programa de justiça restaurativa, que deve seguir sempre apresentando bons resultados, mesmo que a maneira como tenham sido obtidos não fique clara ou disponíveis ao acesso do público, coadunando com os demais índices que sustentam a boa imagem que o município construiu.

Salm (2012) é um autor que não somente argumenta em prol do modelo alternativo da justiça restaurativa, mas em igual medida reforça o importante papel das avaliações das iniciativas que se propõem a empregá-la. Esta crítica é bastante relevante posto que aqui em nosso país isto não tem sido a regra. Em igual medida, uma das críticas do Ilanud (Instituo Latino-Americano das Nações Unidas) feitas após a avaliação dos programas piloto de justiça restaurativa foi a indicação de que faltam dados a respeito das metodologias de avaliação e a divulgação dos resultados das mesmas.

Em relação aos objetivos do programa em São Caetano do Sul, de acordo com a bibliografia oficial, isto é, produzida pelos próprios idealizadores do projeto, eram três os principais objetivos ${ }^{51}$ :

- Atuar no âmbito do Fórum realizando círculos neste espaço;

- Fortalecer a rede de atendimento que atua sobre o jovem autor de ato infracional;

- Evitar o encaminhamento de casos escolares para os trâmites judiciais criminais.

\footnotetext{
51 Esses dados foram retirados da literatura organizada pelos próprios idealizadores do programa: Justiça restaurativa e comunitária em São Caetano do Sul: aprendendo com os conflitos a respeitar direitos e promover cidadania. MELO, E.R; EDNIR, M; YAZBEK, V. C. Secretaria Especial dos Direitos Humanos da Presidência da República. Rio de Janeiro: CECIP, 2008, 192 p.
} 
Estes três objetivos iniciais do programa constituem uma das informação mais importantes para se compreender sua estrutura e dinâmica, como veremos ao longo do texto. Destaca-se, nesse caso, o terceiro objetivo descrito, a tentativa de evitar que os conflitos escolares cheguem até o Judiciário.

Sobre a singularidade que este programa apresentaria, em relação aos demais instaurados, ou seja, o foco sobre estes conflitos escolares, o juiz articulador do programa em São Caetano do Sul argumentou em entrevista:

A gente tem esse levantamento que cerca de $1 / 4$ dos casos que vem pra justiça são de conflitos escolares. Então essa era uma premência local. Agora, eu não sei se tem muita expressão em outros países essa articulação entre justiça e educação, há projetos em educação e há projetos em justiça, mas essa interface eu acho que é bastante singular na justiça.

Fazendo um retrospecto do desenvolvimento do programa nessa cidade, a partir da literatura elaborada por seus próprios organizadores, temos que numa primeira etapa o foco do projeto eram as escolas e os adolescentes em conflito com a lei. O projeto se chamava “Justiça e Educação: parceria para a cidadania". Nesta etapa as mediações ocorriam, além das escolas, no Fórum e no Conselho Tutelar.

Assim, em meados de 2005, o juiz da Vara da Infância e Juventude deste local mobilizou parceiros no Judiciário para a concretização do projeto que envolvia nessa época apenas três escolas. Foram eles: a Secretaria de Estado da Educação que, por sua vez, autorizou a diretoria de Ensino de São Bernardo do Campo - essa diretoria é responsável também pelas escolas de São Caetano do Sul -, o Conselho Municipal de Direitos da Criança e do Adolescente, Conselho Tutelar, Conselho Municipal de Segurança, o Cartório da Infância e da Juventude, dentre outros órgãos. Outros importantes parceiros nesse processo são o constantemente citado CECIP (Centro de Criação de Imagem Popular) e a APS Internacional da Holanda, ambas ONGs.

O segundo movimento do projeto em São Caetano do Sul foi a ampliação do escopo da gestão dos conflitos sob o paradigma restaurativo para a comunidade em geral. Instaurouse, então, o $2^{\circ}$ Piloto na Comarca: "Restaurando Justiça na Família e na Vizinhança: Justiça Restaurativa e Comunitária no bairro Nova Gerty". Nova Gerty é considerado um dos bairros com maior concentração de episódios de violência na cidade. Ali os círculos são realizados no espaço da Escola Estadual Padre Alexandre Grigoli e visavam, inicialmente, atender conflitos 
domésticos e de vizinhança numa parceria com a Guarda Municipal, Polícia Militar e Programa de Saúde da Família. A iniciativa de justiça comunitária contou também com o apoio da Prefeitura do município na época.

Sobre a atuação da justiça restaurativa junto à comunidade Melo (2008) ressalta:

\begin{abstract}
Pretende-se, com isso, enfrentar igualmente um problema interinstitucional e comunitário: esses conflitos são majoritariamente responsáveis pelo insucesso quando ocorre do Bolsa Família (programa nacional de complementação de renda); provocam alterações no comportamento de crianças e adolescentes; são responsáveis por cerca de $60 \%$ do atendimento de rua da polícia imobilizando as tropas para enfrentamento de crimes mais graves, além de afetar cerca de $30 \%$ das famílias conforme levantamento da Organização Mundial da Saúde (MELO, 2008, p. 153.).
\end{abstract}

Facilitadoras de justiça da cidade afirmaram que o envolvimento dos profissionais no início do projeto era tão grande que a própria polícia mandava diretamente alguns casos para o projeto.

No mesmo ano de 2006 mais escolas de São Caetano do Sul aderiram ao projeto, nesse caso, todas as 12 escolas da rede estadual do município.

Em setembro do mesmo ano, a Secretaria de Estado da Educação de São Paulo, com o apoio do MEC, decidiu apoiar a ampliação do projeto para mais duas Diretorias de Ensino: em Heliópolis (São Paulo) e Guarulhos. Na primeira, o projeto ficou sob coordenação de um juiz de Direito designado especialmente para a implementação do programa na capital. Na segunda localidade, por um juiz de Direito da Vara da Infância e da Juventude da Comarca de Guarulhos. Hoje sabemos que estes dois programas não tiveram a mesma continuidade que São Caetano do Sul.

Como consta também no material sobre o programa em São Caetano do Sul, na cidade de Campinas, um projeto de mesma natureza inicio-se em 2008 com previsão de expansão para mais dez cidades do interior de São Paulo. Essas extensões contaram com o apoio financeiro do Ministério da Educação que repassou verbas do Fundo Nacional de Desenvolvimento de Educação (FNDE) à Secretaria de Estado da Educação de São Paulo, via Fundação para o Desenvolvimento da Educação (FDE). Veremos adiante na tese um pouco do contexto do município de Campinas em relação a esta iniciativa.

Organizadores do programa em São Caetano do Sul definiram ainda um $3^{\circ}$ movimento do projeto em que a preocupação voltou-se para o aperfeiçoamento do programa e melhor 
articulação ou adequação entre seus principais órgãos ou atores, ou mesmo melhoras nos atendimentos prestados e nas capacitações para aqueles engajados no projeto.

Entre janeiro e outubro de 2007 houve uma interrupção dos financiamentos que prejudicou o programa, mas ele prosseguiu e em dezembro foram retomadas as capacitações dos facilitadores de justiça e lideranças educacionais graças ao apoio financeiro da Secretaria de Estado da Educação de São Paulo, por meio da Fundação para o Desenvolvimento da Educação.

Em 2008 estendeu-se a atuação do projeto, que além de contemplar conflitos no bairro Nova Gerty, também passou a mediar conflitos comunitários do bairro Prosperidade, de população de baixa renda e bastante afastado em relação à localização dos demais bairros.

No início do programa todas as escolas da rede pública foram capacitadas e elas próprias realizavam, no ambiente escolar, círculos para atender problemas entre alunos e funcionários. Além disso, um grupo de facilitadores atendia os casos envolvendo conflitos na comunidade. Ao longo do tempo, segundo os relatos colhidos no trabalho de campo, devido a um movimento de municipalização que vinha ocorrendo na cidade, houve muitas permutas de cargos de maneira que muitas escolas passaram a contar com apenas um professor capacitado para realizar o tipo de mediação proposto pelo projeto. Sozinhos, deixaram de fazer os círculos e os casos passaram a ser atendidos em apenas uma escola pelo grupo de facilitadores que restou.

Até o momento de realização do trabalho de campo para o doutorado, o programa de justiça restaurativa em São Caetano do Sul pode ser descrito como possuidor de duas frentes, a partir dos locais onde são realizados os procedimentos relacionados ao modelo alternativo; são realizados círculos restaurativos tanto no espaço do Fórum, quanto em uma escola pública do município.

Sobre as intervenções restaurativas que acontecem no Fórum da cidade, não será possível falar a respeito delas, tendo em vista acontecerem num espaço de domínio do juiz responsável pela inciativa; o acesso para a pesquisa não foi permitido ali.

Já em relação às escolas, sabe-se que, embora grande parte das estaduais da rede pública de ensino tenha sido capacitada, apenas uma continua participando ativamente do programa realizando círculos.

A escola se chama Padre Alexandre Grigoli e ali são realizados dois tipos diferentes de atendimentos vinculados à justiça restaurativa. Existe no local uma professora que realiza círculos com alunos do ensino fundamental e médio, para resolver contendas entre alunos, professores, ou funcionários da escola; além de três facilitadoras, que atendem nesta escola, 
aos sábados, casos da comunidade, ou casos que até se originaram nas escolas, mas que resultaram em processos criminais e foram encaminhados para o círculo restaurativo pelo próprio magistrado ou promotor que atende o caso.

O juiz acompanha de perto o programa e todos os casos passam pelo seu crivo; são resolvidos na escola casos que já vem com sua indicação e mesmo aqueles que se originaram na escola, sem necessariamente se constituírem enquanto matéria para processo criminal, vão para o Judiciário, depois da realização do acordo pós-círculo, o juiz ou promotor neste caso não aplicam a pena e decidem seu fechamento.

Hoje, apenas não vão mais para o juiz da Vara da Infância e Juventude do município casos de conflitos que aconteceram na escola e que envolvem unicamente os alunos do ensino fundamental ou médio, geralmente crianças, e que são resolvidos pela própria facilitadora no local. Esta facilitadora é uma professora que não pode mais exercer sua função, mas que continua sendo funcionária, tendo, então, começado a se dedicar somente à justiça restaurativa. Mesmo esses casos, como ela relatou, no início do programa também seguiam para o juiz - ela produzia um relatório e enviava. De acordo com o seu depoimento, isso não acontece mais, os registros ficam todos com ela.

Nesse sentido, reconheceu-se neste local a importância de não se levar mais os casos atendidos segundo os métodos da justiça restaurativa para a homologação pelos juízes e promotores. Isto iria contra os princípios de informalidade do processo e contra os anseios de ajuda pra "desafogar" o sistema oficial, na medida em que os casos voltam a ocupar espaço dentre as atribuições destes profissionais do Direito. Aliás, a necessidade de homologação foi uma das críticas feitas pela avaliação realizada pelo ILANUD (Instituto Latino-Americano das Nações Unidas Para Prevenção do Delito e Tratamento do Delinqüente) em São Caetano do Sul.

(...) no começo esses termos eram encaminhados para o juiz e para o promotor, São Caetano também. Lá em São Caetano quando foi feita uma avaliação pelo ILANUD, do projeto, dos três projetos piloto, uma das críticas que foram feitas ao projeto dele, de lá, é que ao fazer isso, essa formalização, esse encaminhamento para o juiz e o promotor, estaria aumentando o controle em atos que às vezes sequer chegavam ao conhecimento do juiz (...) e daqui a pouco você via pais de alunos "escuta, só porque o meu fillho puxou o cabelo da outra e foi pro promotor, mas o que é isso? que absurdo! (...) (Juiz de São Paulo entrevistado). 
Cabe acrescentar também que se, eventualmente, uma das partes não comparecer ao círculo marcado (algo que é bastante comum, como foi possível constatar no trabalho de campo), ou se não desejarem participar, nesses casos, segundo as facilitadoras entrevistadas, o círculo não acontece, já que as pessoas devem participar voluntariamente. Mas, se num caso enviado pelo fórum uma das partes não comparecer, a ausência é comunicada ao juiz e então ele pode não mais "convidar" e sim convocar a pessoa a comparecer e participar do círculo novamente ou não, de modo que a decisão passa a ser do magistrado.

Dessa forma, ainda que o programa represente uma inciativa que transfere o ritual de administração de conflitos para uma esfera mais informal, a justiça restaurativa neste caso não consegue se desvincular totalmente do sistema de justiça comum, pois a maior parte dos casos a serem submetidos ao modelo alternativo são determinados pelo juiz responsável, de maneira que as suas práticas parecem geralmente ter sua capacidade de resolver problemas circunscrita aos poderes de definição do Estado (Froestad; Shearing, 2005). Isto fica evidente na tendência para que os programas restaurativos recebam casos apenas depois deles terem sido caracterizados, definidos como crime.

Cabe questionar, também, essa aparente voluntariedade das partes em participar do círculo, já que a justiça restaurativa é apresentada sempre ao jovem e sua família como melhor opção, por não resultar em registro da ficha criminal. Sobre isso Zernova e Wright (2007, pp. 97-98) discorrem: “justiça restaurativa completamente voluntária talvez seja um ideal fantasioso. Enquanto a justiça restaurativa operar na sombra do sistema de justiça criminal, a coerção judicial estará presente num segundo plano".

Outros entrevistados indicaram também que entre seguir com um processo e serem convocados à comparacer ao Fórum ou Conselho Tutelar, os pais tendem a preferir resolver o problema de acordo com a justiça restaurativa. Mesmo os casos que recebem a indicação do juiz, ressaltam que é dada a oportunidade de optarem pela justiça restaurativa ou prosseguirem nos trâmites oficiais. Todos os integrantes do projeto entrevistados afirmaram que os potenciais participantes dificilmente se recusam a integrar o círculo depois de conhecerem mais sobre a justiça restaurativa e verem como são as partes componentes do método.

A respeito de dados mais gerais e recentes sobre o programa em São Caetano do Sul, se não foi possível obtê-los, consegui, por outro lado, dados pontuais com a facilitadora de conflitos da escola, que realiza círculos com alunos do ensino fundamental e médio. Os dados não são representativos de todo o programa na cidade, pois se referem somente a uma escola, ao passo em que são feitos, neste local, círculos de outros casos enviados pelo Fórum, além de 
o próprio Fórum sediar círculos também ${ }^{52}$. No entanto, estes dados a que tive acesso não deixam de ser interessantes e permitem tecer algumas inferências. Cabe também a ressalva de que não foram acompanhadas as condições nas quais estes dados foram recolhidos, nem qual o tratamento dado em termos metodológicos (os gráficos foram feitos por mim a partir dos dados recolhidos).

O gráfico 1 compara o número de casos atendidos entre os anos de 2010 e 2011, divididos pelo tipo de atendimento:

Gráfico 1 - Casos por categoria - 2010/2011

Gráfico 1 - Casos por categoria, 2010/2011

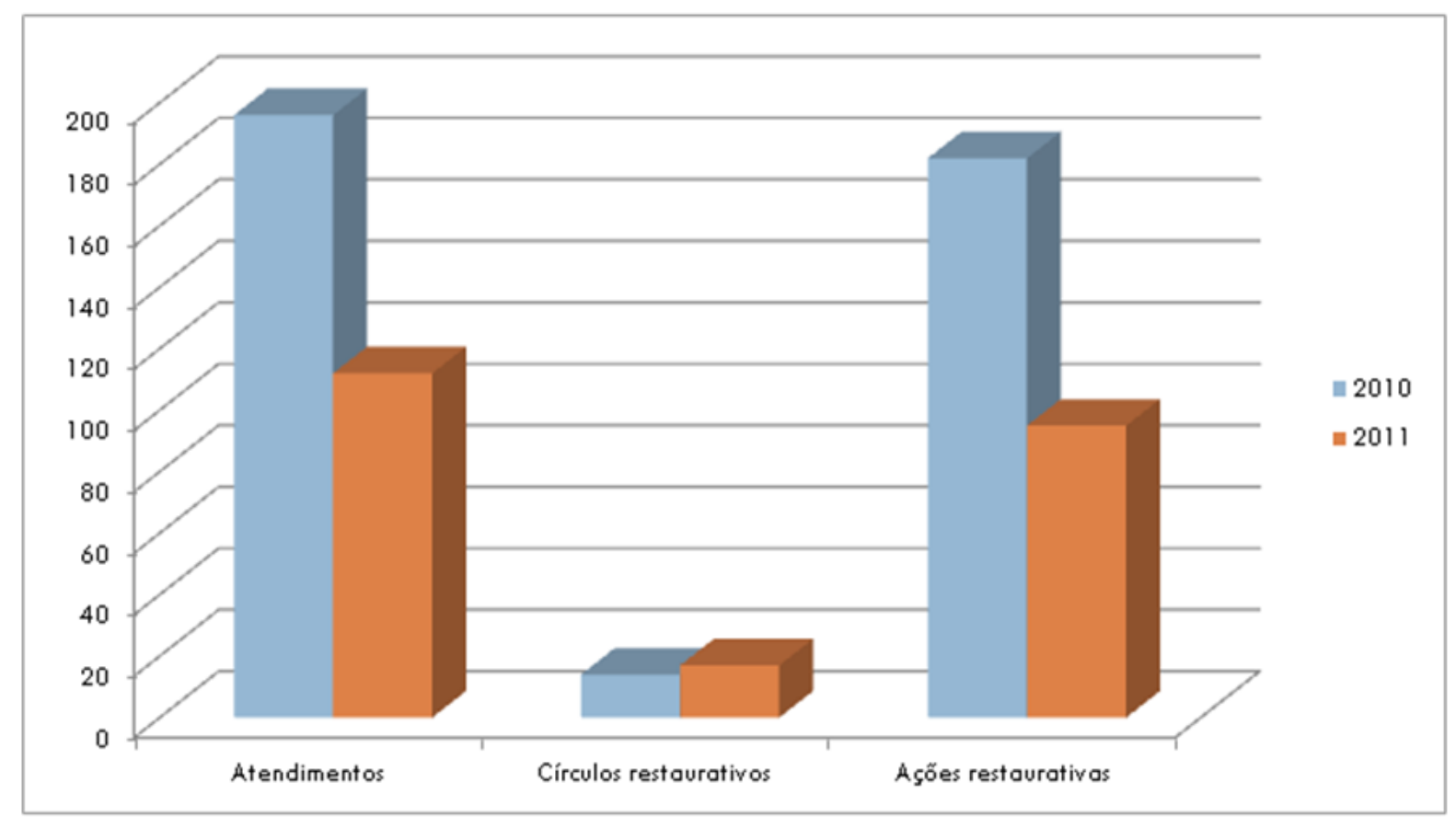

Fonte:E.E.P.G. Pe. Alexandre Grigoli, São Caetano do Sul

Este primeiro gráfico exemplifica bem um ponto relevante que emergiu do trabalho de campo, a questão da terminologia a respeito da justiça restaurativa. Durante as incursões (em São Caetano do Sul, Campinas, São Paulo e São José dos Campos) pude observar uma confusão de conceitos - os termos são diversos: justiça restaurativa, círculos restaurativos, ações restaurativas, atendimentos restaurativos e os interlocutores ora os utilizam como se

52 Sobre os círculos no fórum, como é possível entrever, dada a maior proximidade e controle destes procedimentos pelo juiz coordenador do programa, foi vetado o acesso para fazer campo ali. 
fossem a mesma coisa, como se fossem sinônimos, ora como se fossem coisas diferentes. Salta aos olhos também o baixo número de círculos realizados frente ao número de atendimentos e ações restaurativas.

Uma possível explicação para o quadro seria originária do fato de que o círculo restaurativo demanda mais tempo de todos os envolvidos, em comparação com os outros tipos de atendimento. Ainda mais se forem seguidas todas as etapas componentes do processo: o pré-círculo, o círculo e o pós-círculo, as quais serão vistas com mais detalhes adiante.

O diretor da escola de Campinas, capacitada para trabalhar com a justiça restaurativa, relatou em visita à escola, que seria justamente este o motivo pelo qual o modelo não foi encampado naquele local, ou seja, o procedimento demanda um tempo que eles não possuem no dia-a-dia da escola, em meio ao surgimento de tantos conflitos, muitas vezes simultâneos, devido às proporções da escola que possui um grande número de alunos de todas as idades.

Em relação ao segundo gráfico, este distribui entre os mesmo anos os casos de acordo com o tipo de conflito:

Gráfico 2 - Casos por categoria de conflito, em \% - 2010/2011

Gráfico 2 - Casos por categoria de conflito, em \%, 2010/2011

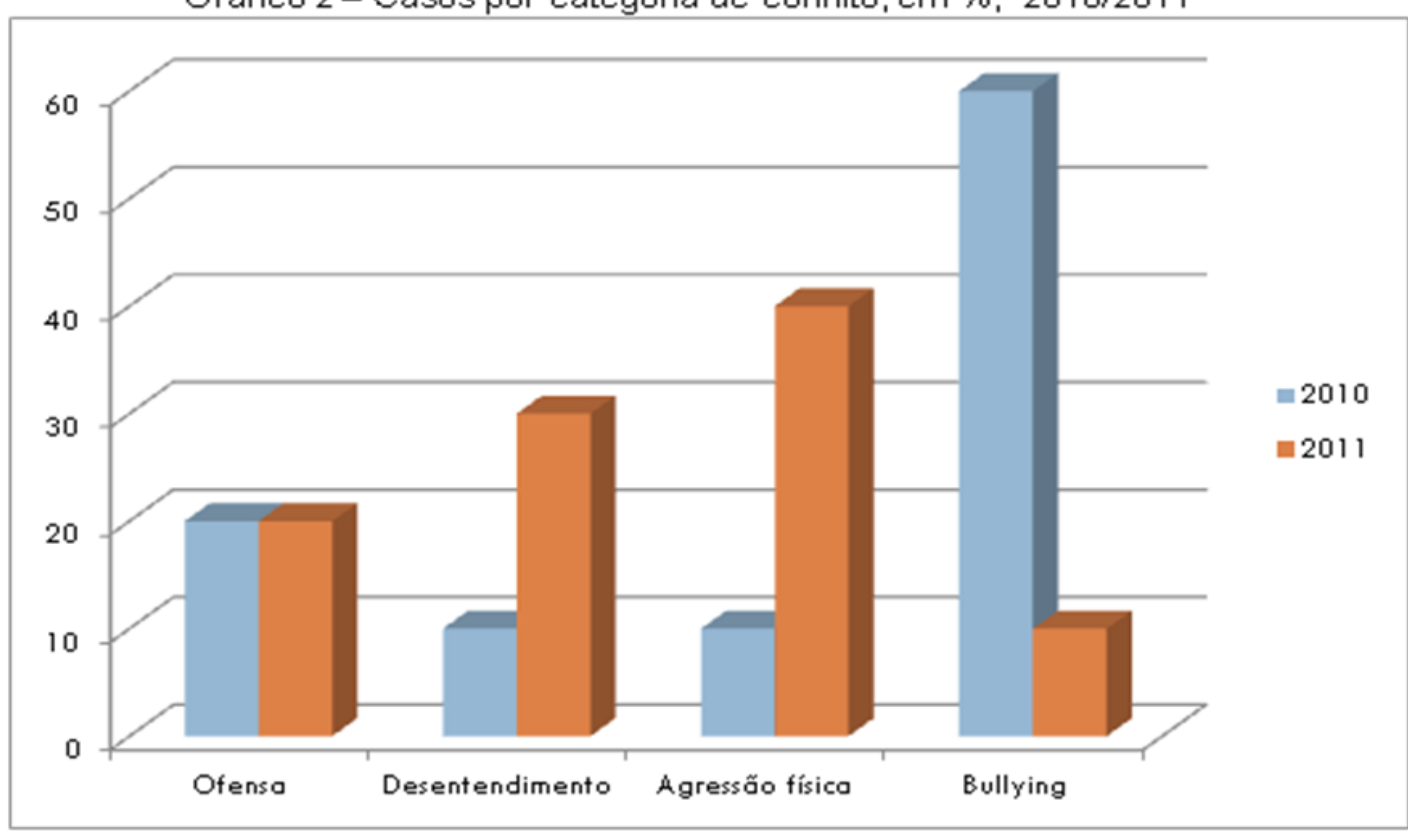

Fonte:E.E.P.G. Pe. Alexandre Grigoli, São Caetano do Sul 
Neste segundo gráfico destaca-se o número alto de casos de bullying ${ }^{53}$ no ano de 2010. Em grande parte isso se deve à grande repercussão que o termo teve no Brasil, sendo constantemente reportados pela mídia impressa e televisiva casos de chacinas em escolas, cometidas por (ex) estudantes que se sentiram vítimas de constantes ofensas e exclusão. Casos assim aconteceram em diversos países, inclusive no Brasil ${ }^{54}$. O fenômeno certamente exerceu grande influência sobre esse contexto e é possível pensar em que medida muitos casos, antes encaixados como bullying, depois foram categorizados como desentendimento, ofensa, agressão verbal ou outros.

Um segundo ponto diz respeito às inversões que ocorrem em todas as categorias de conflito do gráfico de um ano para outro. Excluindo a categoria ofensa, que se manteve constante, os demais inverteram seus números na passagem de 2010 para 2011, na verdade, ou mais que dobraram, ou caíram mais da metade.

\subsection{OS FACILITADORES DE JUSTIÇA}

Segundo o depoimento de algumas facilitadoras de justiça do projeto de São Caetano do Sul, em julho de 2006 foi realizada a primeira capacitação para formação de mediadores, ou facilitadores de justiça, maneira como se autodenominam. Não é preciso ser um profissional da área do Direito para atuar nos círculos restaurativos, qualquer pessoa da comunidade pode realizar a tarefa desde que tenha sido treinada para isso. Foram capacitados, no primeiro curso, cerca de trinta pessoas entre profissionais da área da saúde; aposentados; jornalistas; advogados; professores; psicólogos; policiais; assistentes sociais; e outros. Estes facilitadores tomaram conhecimento do projeto a partir da divulgação feita em igrejas, associações da terceira idade e outras organizações, ou através da indicação de colegas.

Segundo estas facilitadoras, integrantes do projeto entrevistadas, em março de 2008 foi realizado o segundo curso de capacitação, que contou ainda com cerca de doze ou quinze participantes.

\footnotetext{
${ }^{53} \mathrm{O}$ bullying é um termo de origem inglesa - ainda não há tradução para o português - utilizado para descrever violências físicas ou morais que geralmente ocorrem em ambientes escolares. Pode ser definido, em linhas gerais, como uma atitude agressiva e intencional dirigida repetitivamente a um indivíduo ou grupo, a partir de uma relação desigual de poder. Disponível em: http://www.bullying.org/. Acesso em: 10/06/2013

${ }^{54}$ Aqui no Brasil, no dia 07 de abril de 2011, Wellington Menezes de Oliveira invadiu a Escola Municipal Tasso da Silveira, no Rio de Janeiro, e matou 13 crianças antes de se suicidar. O caso foi bastante explorado pela mídia e um dos motivos apontados para o fato foi bullying. É notório o caso de que no Rio de Janeiro foi sancionada uma lei estadual, em 23/10/2010, obrigando escolas públicas e privadas a notificarem casos de bullying à polícia.
} 
Dessa maneira, se à época da instalação do projeto cerca de 30 pessoas teriam sido capacitadas em curso que ocorreu em julho de 2006, e ainda em março de 2008 mais doze ou quinze pessoas foram capacitadas, salta a vista que hoje o projeto conte com apenas três facilitadoras permanentes para atender os casos, além de uma professora que realiza círculos na escola em que trabalha.

Um ex-facilitador entrevistado afirma que o principal motivo para a desistência da maior parte dos envolvidos é a falta de remuneração. Ele acredita que parte dessas pessoas estava interessada somente no dinheiro que um projeto de tal envergadura poderia trazer. Estariam interessadas em um emprego público e numa remuneração que, segundo ele, já tinha percebido que não viria, e que também não seria pra vir porque em sua opinião trata-se de um trabalho de caráter essencialmente voluntário. Houve essa cisão entre os facilitadores e grande parte deixou o trabalho.

Outras facilitadoras entrevistadas endossaram o ponto de vista deste entrevistado, mas especificaram as divergências ocorridas. Afirmam que realmente havia interesse por parte de algumas pessoas em receber remuneração pelo trabalho, mas como os benefícios não vinham, não se sentiam obrigados a honrar o compromisso: "eu vou quando quero". Além deste tipo de problema, afirmam que dentre os participantes da primeira capacitação houve efetivamente conflitos pessoais, brigas e discordâncias sobre como deviam ser conduzidos os atendimentos.

Nesse sentido, como relata uma facilitadora de justiça do projeto, certa vez um facilitador disse: “Ai, pelo amor de Deus, meia hora é muito tempo" (para o atendimento), já outros relataram que tiveram que conduzir casos que duraram cerca de cinco horas, todos dentro de uma sala. Em sua opinião, portanto, estes tipos de comentários geram uma série de conflitos, pois cada um trabalha de um jeito e "às vezes, você tem que mesclar tudo o que você aprendeu".

Já em relação à segunda capacitação, as pessoas teriam abandonado o projeto porque não se sentiram motivadas. Diante da situação instaurada pelos participantes da primeira capacitação, afirmam que para a segunda o juiz teria "prometido" certificados, melhorias, o que de fato não houve. O que os facilitadores recebem é um lanche da prefeitura "e só" e ainda afirmam: “Às vezes não tem papel, às vezes tem que trazer de casa”. Mesmo com as dificuldades, cabe ressaltar que nenhuma das três facilitadoras que restaram no projeto tem planos de abandonar a questão, pelo contrário, os relatos mostram que apesar dos custos elas se sentem realizadas exercendo o trabalho de mediadoras e mostram também grande admiração pelo juiz responsável pela implantação do projeto, não tendo, portanto, nenhuma 
intenção de abandoná-lo. Ainda sobre o número restrito de facilitadores que sobraram, uma facilitadora relata:

\begin{abstract}
No começo tinham várias psicólogas, eram quatro psicólogas que vinham pra supervisão, mas depois elas não puderam vir mais, então eles queriam que nós fôssemos, nós fizemos cursos pra supervisão, nós três fizemos, mas não vinha ninguém pra atender e como que nós íamos ser supervisoras? Não tinha nem pra quem supervisionar, tinha que fazer o trabalho! Então voltamos, a continuar atendendo e não tem supervisão. (Facilitadora de justiça de São Caetano do Sul)
\end{abstract}

Durante entrevistas também foi reforçada a ideia de que a justiça restaurativa lá está muito centrada na figura de algumas pessoas, se o juiz da área na cidade já era apontado como uma pessoa fundamental no programa, agora ressaltou-se também a atuação de uma das facilitadoras. Segundo um ex-facilitador entrevistado, o projeto na cidade só continua se essa facilitadora prosseguir com seu trabalho, dessa forma, se ela parar, o programa para também. As próprias facilitadoras, as três que restaram assumem: “Agora aqui em São Caetano, se a gente parasse, uma de nós parasse o projeto acaba!".

O fato de a justiça restaurativa estar centrada na figura de algumas pessoas e de se apresentar mais ou menos organizada de acordo com os diferentes locais em que vem sendo aplicada, mostra que seu grau de institucionalização ainda é baixo, estando também sujeita às oscilações das vontades políticas de dirigentes do Judiciário local. A rede que apóia a pauta pode, portanto, impulsionar o modelo, mas efetivamente não tem sido suficiente para mantêlo na prática.

De acordo com documentos relativos aos projetos de justiça restaurativa a serem implantados em novas regiões do estado de São Paulo, especificamente no documento intitulado Proposta de trabalho para os projetos de justiça restaurativa e comunitária de São Caetano do Sul em 2007 (Documento de 15/06/2007), fica bastante clara a preocupação de seus relatores para que a iniciativa se torne uma política pública, o que tornaria possível criar formas de autosustentabilidade para que o programa não dependa de recursos ou financiamentos extraordinários.

Neste projeto pode-se ler que: “ (...) paralelamente a esta proposta local, será apresentada uma proposta de elaboração de uma política pública nacional de implementação da justiça restaurativa no país (2007, p. 6). No mesmo documento, como objetivo geral, apresentam: "Construir e sedimentar em São Caetano do Sul um modelo referencial de política de justiça restaurativa e comunitária no país para lidar com conflitos envolvendo 
crianças, adolescentes, suas famílias e comunidades em espaços diversificados, institucionais ou não".

Com o passar do tempo, foi possível verificar que estes objetivos não se concretizaram e o programa em São Caetano do Sul continua com muitas dificuldades. Ele não se extingue, como aconteceu em outros locais, visto que atende a algumas expectativas e estratégias profissionais, mas também não consegue alcançar novos patamares, como por exemplo tornar-se uma política pública nacional, como almejam alguns de seus incentivadores.

\subsection{ADENTRANDO OS CÍRCULOS}

Todos os círculos a serem relatados foram realizados na Escola Estadual Padre Alexandre Grigoli, anteriormente mencionada, do bairro chamado Nova Gerty, município de São Caetano do Sul. Este bairro é considerado um dos que apresentam maiores índices de violência na cidade, segundo o relato dos interlocutores. Sobre esta região da cidade, Melo a define da seguinte maneira:

É o bairro com maior concentração de cortiços na cidade e com maior índice de atendimentos pela Polícia Militar, Civil e Guarda Civil Municipal, voltados à violência doméstica e conflitos de vizinhança. O bairro faz divisa com favela de grandes proporções na cidade de Santo André, cuja comunidade frequenta escolas e outros serviços na cidade. Isso provoca não apenas uma sensação de ameaça, como ainda um certo embaralhamento do próprio conceito de comunidade que, presa aos seus limites territoriais, não consegue perceber as interfaces com os circundantes. (MELO, 2006, p. 64)

A seguir, serão descritos seis casos de atendimentos observados nesta escola. Os casos assistidos, enviados pelo Fórum da Vara da Infância e Juventude do município, foram atendidos em sábados, no período da manhã, e realizados ou na sala da biblioteca da escola, ou em uma das salas de aula da escola. Assistiu-se a círculos nesses dois lugares e ambos passam a impressão de improviso, visto que não foram idealizados para a realização dos procedimentos restaurativos. Na sala da bilioteca, os encontros ocorreram em meio a estantes de livros e um monitor de TV e quando os círculos aconteceram na sala de aula todos ficaram sentados nas carteiras das crianças. Cabe sublinhar, entretanto, que em todos os casos foram respeitadas as disposições das cadeiras ou carteiras em forma de círculo. Do lado de fora, no 
corredor da escola, não existem cadeiras ou bancos para que as pessoas que aguardam se sentem.

Como vimos, existe também outro tipo de atendimento realizado nesta escola. Há uma professora que realiza círculos para resolver, em geral, questões entre os prórios alunos. Nesse caso, os procedimentos acontecem durante a semana, no período das aulas, e esta professora atende os envolvidos em sua própria sala, preparada para a realização do 'ritual' restaurativo.

A maior visibilidade que o tema da justiça restaurativa está tendo também atrai pesquisadores interessados pela temática ou pelo programa especificamente. Em um sábado de plantão, havia uma pesquisadora da área da psicologia social presente. A pesquisadora relatou que já havia assistido a outros círculos e nesse dia, como havia faltado uma facilitadora (são sempre duas realizando os círculos), ela estava ajudando na condução do caso. Em outro sábado também havia alunas de um curso de pedagogia, que estavam ali a fim de recolher material para a realização de um trabalho para a faculdade.

Sobre o procedimento em si, a metodologia que foi disseminada pelo país, nas regiões em que funcionam programas ou em que se pretendia inaugurar, foi desenvolvida em grande parte por Dominic Barter, representante da Comunicação Não Violenta no país. O processo restaurativo, de acordo com esta metodologia, é dividido em três partes: o pré-círculo, o círculo (propriamente dito) e o pós-círculo.

No momento denominado pré-círculo, as partes envolvidas no conflito são atendidas individualmente pelo facilitador de justiça (mediador). Neste momento, são explicados aos potenciais participantes o que é a justiça restaurativa e como funciona o círculo. Os envolvidos são convidados, então, a participar, se assim desejarem, de modo que em relação ao ofensor, para que ele possa fazer parte do procedimento, precisa se responsabilizar pelo ato. Da mesma forma, a vítima da situação deve aceitar se reunir com o ofensor. Se esta parte do pré-círculo estiver concluída, de comum acordo, passa-se para a realização efetiva do círculo.

Neste momento as partes envolvidas na situação conflituosa são ouvidas individualmente pela facilitadora e só depois todos se reúnem (vítima, ofensor e seus acompanhantes) para decidirem, juntos, as formas de reparação do problema. A disposição dos presentes acontece na forma de um círculo e todos em teoria teriam oportunidades iguais para falarem sobre o assunto, sem serem interrompidos ou julgados uns pelos outros.

Finalizada a sessão, o pós-círculo emerge como o momento de conclusão do ritual. As maneiras de realização do pós-círculo passam a depender do desfecho do caso: a facilitadora pode se comprometer a acompanhar os alunos na escola para verificar se a situação se 
pacificou, ou pode visitar as famílias para verificar se houve alguma melhora nos relacionamentos, por exemplo. $\mathrm{O}$ fato é que, em geral, fica acordado entre os presentes que em algum momento eles devem se reunir com a facilitadora novamente, para dizer se o caso foi resolvido, ou não, e assinar um documento para que o juiz, satisfeito com a decisão, conclua e arquive o caso.

\subsubsection{Caso n. 1}

Este caso foi o primeiro círculo assistido para a pesquisa. Aconteceu na bilioteca da escola em São Caetano do Sul. Neste dia apenas uma das facilitadoras estava presente (geralmente são duas) de maneira que uma estudante de psicologia que estava no local para assitir ao procedimento tomou o lugar da facilitadora ausente e passou a ajudar na condução do procedimento. Mas a estudante pouco falou, não interferiu muito no processo.

Este círculo foi acionado para tratar de um conflito que envolvia um professor da rede pública de ensino e um aluno da mesma escola (escola diferente daquela onde o procedimento restaurativo estava sendo realizado). O professor em questão fez um Boletim de Ocorrência contra o aluno porque este o teria ameaçado. O juiz da vara competente da cidade delegou, então, este caso para que fosse resolvido de acordo com o programa de justiça restaurativa, que funciona na localidade.

O primeiro a conversar com a facilitadora de $\operatorname{conflitos}^{55}$ (mediadora) foi o professor, a parte no conflito que se sentiu lesionada e que procurou recursos (os demais aguardaram fora da sala). Ele foi acompanhado de outra professora, uma colega da mesma escola que, assim como o próprio professor, vivencia muitos problemas em comum. Foram relatados pelos dois diversos episódios de desrespeito com professores e demais funcionários da escola, casos de depredação do patrimônio público, entre outros. Percebeu-se, desde o início deste círculo restaurativo, que o caso particular do professor em sua discórdia com o aluno, misturava-se o tempo todo com outros problemas e conflitos recorrentes no espaço da escola.

O professor estava munido de um boletim do aluno, no qual era possível observar seu baixo rendimento escolar. Neste boletim, constavam, em particular, as faltas do aluno as quais o professor fez questão de contar (a soma chegava a cerca de 180 faltas) além de um relatório

\footnotetext{
${ }^{55}$ Esta é maneira como se autodenominam as facilitadoras de justiça, fazendo clara alusão ao fato de que a função do mediador, segundo a justiça restaurativa, não é a de impor soluções para as partes em conflito, mas sim facilitar o diálogo para que os próprios envolvidos encontrem formas mais consensuais de reparação para os danos causados.
} 
que o professor de educação física havia feito naquela mesma semana, o que demonstrava, segundo o professor, que o aluno continuava se "metendo em confusão" mesmo depois te ser sido chamado pelo juiz para dar as declarações em relação ao Boletim de Ocorrência.

Depois da fala do professor, ele e sua colega se retiraram da sala e em seguida entrou a outra parte do conflito, isto é, o aluno, que foi acompanhado de sua avó. O garoto tinha quinze anos e estava cursando a oitava série pela segunda vez. Falou pouco sobre as acusações do professor, e demais situações que foram relatadas sobre a escola em geral e sua situação escolar mais específica. Inúmeras vezes a avó o incentivava a falar, de modo que ele deu respostas um pouco vagas e disse só ter respondido a xingamentos que teriam partido do professor; disse também que tinha sido mal interpretado, que não tinha feito ameaças.

A avó, em diversos momentos, se sentiu impelida a justificar o comportamento do seu neto; disse que era um bom rapaz, que trabalhava e estudava, nem tendo tempo para o lazer. Após o depoimento do aluno, se reuniram todos à mesa para a conversa final. Não houve total concordância sobre os fatos, porque o aluno insistia numa versão do caso e o professor em outra; houve momentos de confronto e o aluno assumiu parcialmente a culpa pelos acontecimentos descritos.

Mesmo que este seja um momento em que todos têm a oportunidade de falar, ficou muito claro nesse caso como certas hierarquias e relações desiguais de poder se mantém e são difíceis de serem superadas. O professor falou mais, e falou com mais autoridade que o aluno, devido a sua posição superior em relação ao mesmo e também por sua maior capacidade de articulação na fala. Houve um momento em que claramente o que se estava tentando fazer ali era educar o aluno; foram dados diversos conselhos para ele, principalmente pelo professor, para que melhorasse seu comportamento, respeitasse mais os funcionários e professores, que parasse de depredar a escola e ele foi questionado: "Por que você faz isso com a sua família?" A avó tinha dito que a mãe do garoto se sentiu mal quando soube do seu envolvimento no caso.

A facilitadora também mencionou ao aluno o fato de ter sido dada uma chance a ele pelo juiz de resolver seus problemas de uma maneira mais informal, sem penalidades e que caso ele se envolvesse em novos problemas as coisas poderiam ser diferentes: o juiz poderia não levar a situação para o projeto de justiça restaurativa e conduzir nos trâmites tradicionais.

Finalizada a sessão, todos assinaram um acordo e, nas duas próximas semanas, a facilitadora acompanharia o comportamento do aluno na escola para verificar se havia melhorado. 
Neste dia, a diretora da mesma escola mandou outros alunos para o local de realização do círculo. Vários deles foram acompanhados pelos pais ou responsáveis, mas foram dispensados pela facilitadora porque estavam com pressa e ela percebeu que não haveria tempo para atender a todos. Um pai estava muito nervoso com a situação, porque não sabia o que era "justiça restaurativa" e queria saber o que estava acontecendo ali. Este pai acabou indo embora sem saber o que é justiça restaurativa.

Desde este primeiro caso já chama também a atenção o fato de a facilitadora aludir ao adolescente, responsável pelo conflito, que a participação no círculo restaurativo foi uma chance dada a ele pelo juiz, que ele deveria aproveitar. Neste caso, o modelo de justiça oficial vira uma ameaça, pois logo em seguida ela avisa que caso ele volte a cometer algum ato infracional, muito provavelmente não poderá mais resolver o problema de acordo com a proposta alternativa, será pelo modelo de justiça comum. Veremos ao longo das descrições dos casos, como essa fala não é uma exceção, mas a regra em todos os círculos presididos por essa facilitadora.

Este caso chama muito a atenção sob alguns aspectos e por razões que tentarei desenvolver ao longo desta tese. Primeiramente, se tomarmos por base o fato de que a justiça restaurativa, tida como uma forma alternativa de administração de conflitos, apregoa, entre outros, a horizontalização de relações e a busca por formas mais consensuais de solução de conflitos, de maneira que as relações que foram abaladas com o conflito sejam restauradas, algo soa estranho da situação acima descrita. Instigada pelas possibilidades analíticas que este caso sugeria, acompanhei, também, outros casos de conflitos tratados pelo círculo restaurativo ${ }^{56}$, descritos na sequência.

\subsubsection{Caso n.2}

É importante destacar que este caso não pode ser propriamente chamado de círculo restaurativo já que uma das partes não compareceu. A parte ausente foi a parte reclamante, ou seja, aquele que fez o Boletim de Ocorrência, mas a quem se relegou a impressão de ser o verdadeiro "culpado" do caso, de acordo com os demais presentes, como pude observar.

\footnotetext{
${ }^{56}$ Esta também foi possível na medida em que constituiu parte de um subprojeto vinculado à rede de pesquisas do Ineac-INCT. O título da pesquisa empreendida é Justiça restaurativa e mediação judicial pré-processual: experiências inovadoras de administração de conflitos em comarcas do interior paulista. Agradeço a outra pesquisadora que fez parte do subprojeto, Audria Ozores, e à coordenadora da pesquisa Jacqueline Sinhoretto. Ambas foram fundamentais para o desenvolvimento dos argumentos presentes neste texto.
} 
A descrição deste caso, mesmo que não se constitua verdadeiramente enquanto um círculo, pode ajudar já que contém elementos importantes para a análise do programa de justiça restaurativa que funciona na cidade. Este também foi um caso enviado pelo Fórum e o procedimento foi conduzido na mesma biblioteca da escola. No início do procedimento mencionou-se que o ideal seria que a própria comunidade procurasse o projeto por livre e espontânea vontade, o que de fato não ocorre.

A parte acusada, sobre quem foi feito o Boletim de Ocorrência, compareceu e estava bem assistida; foram até a escola uma aluna do segundo ano do colegial de uma escola pública da cidade, do período noturno, sua mãe, seu pai (contra quem, além da garota, foi feito um B.O. também), seu irmão mais novo e uma amiga.

Acatando o pedido dos facilitadores presentes- neste dia excepcionalmente havia três facilitadores - a aluna começou a relatar o ocorrido. De acordo com ela, em um intervalo de aula, enquanto falava ao telefone, um colega de sala, mais velho, de vinte e três anos, começou a ofendê-la, jogando em seguida uma lata de refrigerante em direção ao seu rosto. Quando indagada do motivo por que ele faria uma coisa dessas, ela disse que alguém questionou a sexualidade do garoto naquele momento e que ele pensou ter sido ela quem fez o comentário.

Ficou subjacente entre os facilitadores e à garota e sua família que a provável homossexualidade do aluno é um problema mal resolvido para ele; ao mesmo tempo, a garota admitiu que ele já a havia elogiado anteriormente não tendo sido correspondido. Ficou estabelecido mais um provável motivo que levou o rapaz a ser agressivo com a moça, uma vez que ela não correspondeu a sua investida. Ficou marcado nos relatos, e também foi acordado entre os presentes, que ele já teria problemas anteriores, pois seria um menino “isolado"; também foi especulado por todos que teria "problemas na família".

O que ocorreu depois da agressão mencionada é que o aluno foi atacado por um grupo de rapazes da escola, no momento da saída de todos os alunos. Eles o teriam agredido em solidariedade à garota, contra a qual ele arremessou a lata de refrigerante. A garota disse que desconhecia o fato, mas depois admitiu conhecer alguns dos rapazes que o agrediram, mas que não teria pedido de forma alguma para eles fazerem aquilo. $\mathrm{O}$ garoto agredido chamou a polícia, que foi até a escola e seguiram todos para a delegacia, foram: o aluno agredido, a garota e seus pais. Interessante neste caso como nenhum dos agressores foi até a delegacia prestar depoimento e nem o rapaz agredido fez queixa contra eles; a razão indicada para esse fato é que, segundo os policiais que atenderam ao chamado, seria difícil porque não teria "como provar". 
Ainda na delegacia, em meio aos procedimentos formais de exame de corpo de delito e prestação da queixa, o aluno agredido fez outro B.O., incentivado pelo delegado, porque se sentiu ameaçado pelo pai da garota, o que foi prontamente negado por todos os presentes.

Após o depoimento da aluna, como a outra parte do conflito não compareceu, o procedimento culminou com a assinatura de todos os presentes e com a promessa da facilitadora de que tudo seria relatado ao juiz: a ausência da outra parte e que essa parte teria que comparecer ao próximo encontro restaurativo ou falaria diretamente com o juiz, o que ele, o juiz, decidir.

Mais uma vez a ausência física do juiz não impede que esteja presente, pois é o tempo todo uma figura a quem a facilitadora recorre para tentar dar mais legitimidade ao ritual informal. Por isso, de acordo com a facilitadora, não teria importância se a outra parte não compareceu, visto que o juiz tomará conhecimento do fato; este argumento é utilizado para tranquilizar os presentes.

Ficou evidente, também, que apesar de eles serem parte do conflito acusada pela vítima, o fato de irem até a escola para participar do círculo cria uma empatia com a facilitadora, que vê seu trabalho reconhecido por essas pessoas. O rapaz ausente, por não ter comparecido ao procedimento, demonstrou, de acordo com os presentes, que não é responsável e em nenhum momento especulou-se se não teria ido por não querer resolver a questão por essa via.

\subsubsection{Caso n. 3}

Ainda no corredor, antes do procedimento, aguardavam duas adolescentes e suas mães. Foi possível notar que as meninas eram amigas e conversavam; já as mães reclamaram de ter que comparecer à escola porque trabalhavam. De acordo com elas, era difícil faltar ao trabalho para ir até lá, ainda mais para um caso "bobo" desses de escola; por isso, disseram que se tivessem de ir novamente não compareceriam.

$\mathrm{O}$ caso envolve três adolescentes estudantes de um colégio público do município. $\mathrm{O}$ conflito entre elas se deveu a uma briga em que a vítima saiu ferida. A briga entre as estudantes de quatorze anos aconteceu nas proximidades da escola, depois do período de aula.

Este procedimento foi conduzido em uma sala de aula da escola, de forma que todos nos sentamos nas carteiras das crianças. Apesar do desconforto, pelo fato de as carteriras serem bem pequenas, o formato de círculo foi respeitado. 
Como das outras vezes, antes de começar o círculo, a facilitadora reafirma o peso do procedimento. Como ela, de antemão, já espera um maior descaso da população, por ser uma maneira informal de administração de conflitos, sem a presença do juiz e em uma escola ao invés do Fórum $^{57}$, ela usa a associação da justiça restaurativa com o modelo de justiça comum para que as pessoas se comprometam mais. Então diz que o círculo tem o mesmo peso, que é informal, mas é preciso levar a sério, que tudo ia ser repassado para o juiz: a presença delas, a ausência da outra parte (a vítima e sua mãe não comparecerem) e o possível acordo.

Mais uma vez, como também já presenciei em outros círculos, a facilitadora alude às meninas o fato de ter sido dada uma chance pra elas pelo juiz, de resolverem o caso de uma forma mais branda e que, caso elas se envolvam novamente em conflitos iriam "puxar a ficha" delas e ver que são reincidentes. Então, provavelmente não poderiam mais resolver o problema de acordo com a justiça restaurativa, teria de ser segundo as formas convencionais que, por sua vez, poderiam resultar em penas de medidas socioeducativas, pagamento de cestas básicas ou trabalho voluntário; como também poderiam, em última instância, ir para a Fundação Casa. Nas palavras da facilitadora: "como a gente já sabe quem entra lá dificilmente se recupera, se entra 10\% sai de lá 100\%”.

Nesse sentido cabe ressaltar que defensores da justiça restaurativa apregoam a ideia de que os casos devem ser tratados como e em seus eventos individuais, mas autores como Matthews (2006), entretanto, acreditam que isto é uma ingenuidade: “(...) há uma tentação imperativa de trazer a história prévia do ofensor à tona ${ }^{58}$ (YOUNG, 2001)". Este exemplo mostra como algumas características observadas nos círculos do programa em São Caetano do Sul não são particulares desta localidade, mas antes observadas por pesquisadores em outras iniciativas internacionais de justiça restaurativa.

Este círculo já tinha sido marcado antes pelo juiz e por um problema de comunicação ele marcou em um dia em que a facilitadora não poderia comparecer; as partes já haviam ido então à escola anteriormente, não tendo sido atendidas. Isso colaborou para o descrédito delas no método e para os comentários impacientes que as mães e as meninas fizeram de que não poderiam ir mais. Teria sido por isso também que a outra parte não compareceu, além de a mãe da vítima já ter manifestado vontade de encerrar o caso, de arquivá-lo, como foi contado ali pelas outras partes presentes.

\footnotetext{
${ }^{57}$ Uma facilitadora admite que às vezes se depara com alguma manifestação de desconfiança da população: "Aí quando vê que a coisa tem o respaldo do juiz muda a figura, mas no começo às vezes por ser numa escola: 'Ah, mas é aqui?"

${ }^{58}$ Tradução livre da autora, no original: “(...) there is an overriding temptation to bring the offenders previous history into view".
} 
A facilitadora, por outro lado, afirma que se elas estão ali é porque o caso não foi encerrado; ela verifica a intimação do juiz, recolhe dados dos presentes e pede para que as meninas comecem a contar o motivo de estarem ali.

Tanto a agressora quanto sua a mãe afirmaram que essa teria sido a primeira vez que a aluna se envolve numa briga. A mãe afirma que ela é estudiosa, que nunca se envolveu em problemas, nunca tinha sido chamada antes na escola por questões desse tipo e que justo numa primeira vez “a coisa já foi parar no Fórum”. Já a outra garota entrou no caso porque durante a briga agrediu o irmão da vítima.

Mais uma vez é possível verificar como as mães se sentem impelidas a justificar e a defender a imagem de seus filhos durante a realização do círculo, desvelando como o ritual pode, muitas vezes, trazer à tona sentimentos de constrangimento que não se limitam ao ofensor, mas que atingem também os familiares presentes.

Verifiquei, também, em diversos momentos, alguns julgamentos valorativos proferidos pela facilitadora: "Olha eu não te conheço, estou te conhecendo agora, mas você me parece ser mais agitadinha...”. Em vista desse julgamento, a mãe da adolescente, que era acusada de agressão, se sentiu obrigada, em outro momento, a se justificar: "olha ela pode não parecer, mas ela é uma menina tranquila". O fato de a facilitadora ser mãe e atuar algumas vezes na companhia de sua filha, que geralmente a acompanha em seu trabalho, lidando naquele espaço também com outras mães, isto traz implicações para o procedimento mesmo que se embase num tipo de autoridade diferente daquela exercida pelas figuras dos profissionais do Direito.

As mães e as adolescentes contaram também que a mãe da vítima não tinha intenção de procurar a justiça, que todas elas já tinham conversado e se entendido, mas que ela foi à polícia e fez a denúncia por incentivo da diretora da escola. A diretora, na opinião delas, agindo de maneira antiética, foi quem passou os dados das duas agressoras e de suas famílias, para que a mãe da vítima pudesse fazer a denúncia. De acordo com todos os presentes a diretora não poderia ter feito isso, assim como também não poderia ter punido a menina que agrediu com suspensão por um acontecimento que se deu fora da escola. Além disso, a garota relatou que não pôde apresentar um trabalho porque estava suspensa no dia da apresentação, então a diretora suspendeu a garota novamente porque não apresentou o trabalho.

Os conflitos atendidos pelos círculos restaurativos mesclam-se o tempo todo com outros problemas trazidos pelas partes, de modo que vários problemas escolares se entrecruzam. Foram feitas várias acusações à diretora, como de ter o costume de ofender os 
alunos, entre outros comportamentos considerados irregulares. As acusações foram tamanhas que a facilitadora se comprometeu a entrar em contato com essa diretora.

\subsubsection{Caso n. 4}

Este conflito envolve dois adolescentes (um garoto e uma garota) do ensino médio de um colégio público da cidade. Este caso resultou em um Boletim de Ocorrência e processo, o que o fez ser enviado do Fórum pelo juiz, para o programa de justiça restaurativa, com intenção que fossem ali discutidos os motivos do conflito e possíveis formas de reparação. $\mathrm{O}$ conflito volta, dessa forma, para o espaço da escola, local em que originariamente se iniciou.

A situação de conflito partiu de ameaças que o rapaz de dezessete anos teria feito à sua colega de sala de aula e ex-namorada. O local onde se deu o círculo foi o mesmo do anterior, uma das salas de aula da escola.

A parte acusada é a primeira a ter o momento da fala. Compareceram para o círculo o adolescente e sua mãe, sendo o jovem o primeiro a falar. Desde o início já tenta diminuir sua participação no conflito, afirmando que seus amigos teriam tomado "suas dores" desde o fim do relacionamento e que estariam assediando a adolescente, sua ex-namorada. Admite que o ápice da situação conflituosa ocorreu a partir de algo que ele teria publicado na rede social Facebook, mas não revela qual o conteúdo da mensagem que teria provocado a reação da exnamorada e sua família. Ele e sua mãe disseram que, apesar do ocorrido, tudo já estava bem resolvido entre eles, e que já estavam até conversando, o que de fato era verdade, como pude observar.

Em seguida chegamos ao momento do conselho materno - diversos conselhos são proferidos pela facilitadora, direcionados ao adolescente acusado de ameaça e sua mãe. Mais uma vez a facilitadora utiliza a figura da Fundação Casa (sua falência enquanto instituição responsável pela educação e ressocialização do adolescente autor do ato infracional se constituindo, em sua visão, mais como uma escola do crime) e o aconselha a evitar novos conflitos. Os conselhos são claramente dirigidos ao adolescente, mas o fato de a facilitadora estar ali com sua filha também participando do círculo não é indiferente, isso comunica algo, passa uma mensagem que de fato é entendida pelas mães que acompanham seus filhos em situação de acusação.

Em todos os círculos assistidos que contaram com a participação da mãe do(a) acusado(a), pude observar que se sentiam constrangidas e muitas vezes seguiam com 
justificativas para o filho(a) ter cometido a ação, como indicado anteriormente. A facilitadora diz em um momento: "você parece ser um menino bom". A mãe em seguida se sente impelida a responder e tenta reforçar seu papel de mãe, ela diz: “eu sempre falei pra ele... escola é lugar de estudar e não de namorar, e depois que sair da escola é pra voltar pra casa. Tem que ir pra casa pra evitar confusão, a casa é o melhor lugar pra gente".

A facilitadora questiona o motivo do fim do relacionamento, se ele tinha outra namorada ao que ele responde que não e que teria sido traído. A facilitadora lembra que ali não vai haver um julgamento e com isso ela consegue com que o garoto assuma que é culpado por ter colocado "aquilo" no Facebook; mas, quando questionado sobre o que ele escreveu ele diz não se lembrar. Como foi possível observar nos círculos, a alegação de que ele(a) pode falar, porque ali não vai haver julgamento serve de recurso para a busca pela verdade ${ }^{59}$.

É digno de nota também que a facilitadora não sabe o conteúdo da ameaça, ou seja, ela também não sabe de mais detalhes do caso, não viu o Boletim de Ocorrência, por exemplo, o juiz só forneceu os nomes daqueles que iriam participar do círculo e mais nada.

A segunda parte do conflito, a que se sentiu prejudicada e buscou recursos só chega nesse momento. A adolescente de quinze anos e sua mãe, sendo esta a primeira a começar a falar. Ela afirma que o juiz teria perguntado se ela, a mãe autora do B.O, queria continuar o processo ao que teria respondido que não. Disse também que tentou antes de ir a delegacia resolver o problema por outras vias, tentou conversar com a outra família, tentou conversar na escola e não obteve resultado.

Nesse caso, como podemos observar, foi a formalização do conflito, e não sua informalização, que funcionou. A mãe da garota ameaçada disse que queria mostrar, de alguma forma, para o rapaz, que aquilo que ele estava fazendo era algo sério. De acordo com ela, a utilização da via formal resolveu o problema, porque seus objetivos foram alcançados: disse que depois da feitura do B.O as ameaças terminaram; argumentou, ainda, que, diante do nervosismo do rapaz, tentou conversar, isso não resolveu e viu então no B.O uma possibilidade dele parar com as ameaças e entender finalmente o fim do relacionamento.

A facilitadora pediu para que dali a um mês todos voltassem para relatar se estava tudo bem e assinassem mais um documento, que seria repassado ao juiz para que então encerrasse e arquivasse o caso.

No fim do procedimento as partes assinaram um documento mencionando terem comparecido e que o círculo foi realizado. A mãe da menina questiona porque não foi feito

\footnotetext{
${ }^{59}$ Isso será discutido posteriormente, argumento como esse é mais uma característica trazida do processo formal para o informal, e mais ainda, como isso se relaciona com nossa tradição inquisitorial, comum à Civil Law.
} 
esse círculo antes, porque a escola não fez isso ou não disse que existia essa possibilidade, esse canal. A facilitadora, diante da pergunta para a qual não tem resposta, (ao que poderia dizer que existe um desinteresse sistemático das escolas pelo programa de justiça restaurativa e em contrapartida um grande incentivo à feitura do B.O); somente faz propaganda do programa, diz que qualquer problema eles podem procurá-la, assim como se souberem de alguém que precisa, que não somente podem como devem indicar a possibilidade.

Interessante observar como a justiça restaurativa é um complemento; em São Caetano do Sul ela não substitui os ritos processuais e, portanto, não é aplicada como justiça alternativa. A justiça restaurativa não substitui o processo, não entra no lugar da audiência como se pode inferir deste caso, já que a situação estava resolvida antes mesmo de ser enviada ao círculo.

Isso nos leva a pensar em algumas possibilidades. A primeira delas é a de que o programa cumpriria um papel importante na dimensão profissional do magistrado que o organiza. Este profissional, assim como outros que estão liderando programas de justiça restaurativa pelo país, conduz uma carreira acadêmica paralela ao seu trabalho, além de divulgar em todo o país e até internacionalmente o programa coordenado por ele em São Caetano do Sul; isso, por sua vez, traz à tona novamente as questões profissionais e mostra o quanto o conteúdo crítico desta vertente mais heterodoxa serve para fins de alavancar uma carreira. É interessante notar que esses mesmos dados que são divulgados em publicações próprias do programa não ficam disponíveis para pesquisadores acessarem, tendo em vista minhas tentativas frustradas de obter informações mais atuais, para que pudessem ser citadas no trabalho.

Outra possibilidade diz respeito a um papel moralizante e educador que o juiz não poderia ou não deveria exercer durante a audiência e que é cumprido pela facilitadora durante o procedimento.

No círculo descrito aconteceu, portanto, uma dupla punição e uma revitimização da parte do conflito afetada pela ofensa. Esta é também uma preocupação patente na literatura que discute os modelos informais de gestão de conflitos. Myléne Jaccoud (2005) é uma autora que reflete sobre a justiça restaurativa servir a fins de uma segunda punição. Já Roche (2007, p. 83) expõe como pesquisas mostraram que muitas vezes as duas partes em conflito se sentem envolvidas num processo de punição. Para ele: "a justiça restaurativa não é uma alternativa à punição, mas uma forma alternativa de punição". 


\subsubsection{Caso n.5}

Este caso diverge bastante dos anteriormente descritos, pois não foi um conflito enviado pelo Fórum, portanto não resultante de B.O e processo. É o caso de um conflito que aconteceu na própria escola e que envolveu crianças da quinta série do ensino fundamental. A escola é a mesma onde são resolvidos os conflitos enviados pelo juiz, mas quem conduz estes círculos entre os alunos é outra facilitadora: uma professora da rede de ensino público, que não podendo mais exercer sua profissão, passou a trabalhar somente com justiça restaurativa na escola. Ela divide a sala com a professora mediadora ${ }^{60}$.

O local onde foi realizado este círculo é diferente dos outros. A sala é repleta de cartazes onde é possível observar um cuidado em tentar transformar aquele ambiente num local mais acolhedor, diferenciado dos demais ambientes da escola. Ali existem diversos painéis sobre educação, sobre justiça restaurativa e sobre bullying principalmente. Em um cartaz na sala de atendimento estão descritas, de forma bem didática, todas as etapas que constituem o processo restaurativo:

\section{Pré-círculo:}

1. Quem solicita o círculo é acolhido;

2. Quem é visto como responsável pelo ato é contatado, acolhido e convidado a participar;

3. Os dois são entrevistados individualmente;

4. O facilitador informa os participantes sobre os objetivos e o modo de operar o círculo.

\footnotetext{
$60 \mathrm{O}$ professor mediador foi uma figura introduzida oficialmente nas escolas públicas. Essa medida foi interpretada pelos agentes envolvidos com a justiça restaurativa como mais uma vitória da introdução do modelo no país, embora na incursão pela escola de Campinas, onde se acompanhou o trabalho do professor mediador, não se observou nada que pudesse associar essa função com a proposta da justiça restaurativa.
} 


\section{Círculo:}

"A" -pessoa que foi ou se sente mais prejudicado(a), ofendido(a) por determinada ação

"B" -pessoa que assumiu ter praticado a ação ofensiva ao agressiva

\section{Etapas:}

2. "A" fala -“A" expressa para "B" no tempo presente suas necessidades atuais que estão desatendidas depois do que aconteceu

" $B$ " demonstra para " $A$ " que compreendeu o que ele quis dizer

3. "B" fala - B" expressa para "A" no tempo presente suas necessidades atuais desatendidas depois do que aconteceu

" $A$ " demonstra para "B" que ele compreendeu o que ele quis dizer

\section{Acordo:}

4. "A" e "B": Propõem uma ação ou conjunto de ações que possam ser realizadas principalmente por quem causou o dano, para reparar este dano e restaurar a relação desequilibrada pelo conflito. 


\section{Atenção:}

Facilitador: o papel do facilitador é manter as etapas do processo restaurativo, ajudar as pessoas a se ouvirem e registrar o acordo que fizeram.

Acordo: as ações sugeridas devem ser concretas, específicas e relevantes em relação aos danos causados; para que possam ser avaliadas devem prever prazo de cumprimento.

O conflito deste círculo envolve bullying; trata-se de um garoto de onze anos que se sentia mal e perseguido pelo fato de seus colegas de classe questionarem sua sexualidade. Chama a atenção o fato de que este caso envolvia a própria professora do aluno como uma das pessoas que teriam comentado a respeito de sua sexualidade. A referida professora não participou do círculo e a facilitadora não mostrou se importar com sua ausência, mesmo os alunos tendo relatado que o garoto cuja sexualidade vinha sendo assunto no colégio estava muito descontente com essa professora. Participaram do círculo: o garoto que pediu o encontro restaurativo, que chamaremos de R., e mais cinco colegas de sua turma na escola, além da facilitadora e eu. Ela já no início me apresenta, diz que eu estou lá pra ver como é a justiça restaurativa e logo emenda: “mas ela não vai dar palpite não!”.

A primeira atitude da facilitadora é perguntar a todos os alunos se alguém ali não sabe o que é a justiça restaurativa, ao que em seguida vários erguem as mãos. Ela então prossegue explicando: “A justiça restaurativa é um programa do governo...” Essa é, portanto, a definição da facilitadora, que não é suficiente para os alunos que continuam sem entender bem a proposta. Ela em seguida explica as etapas componentes do processo e depois conclui afirmando que ao final eles têm que fazer um acordo e o seu registro, diz, vai para o fórum para o juiz verificar.

Cada um tem sua vez de falar e a facilitadora não deixa um interromper o outro. R. disse que pediu para fazer o círculo porque queria resolver a situação, queria dizer que estava triste e pedir que parassem de falar sobre sua vida.

Foi bastante interessante perceber qual é a noção que estes alunos têm sobre o que é justiça restaurativa. Em primeiro lugar há que se levar em conta o peso da própria palavra justiça. Ela é detentora de uma carga simbólica grande e os alunos já detêm pré-conceitos sobre seu significado, de modo que os alunos diziam uns para os outros durante o círculo: “Olha, se você continuar espalhando fofoca eu vou te levar na justiça restaurativa!”. A justiça 
restaurativa vira uma ameaça para esses alunos que pouco entenderam do que se trata o modelo alternativo, diante da explicação da facilitadora.

No decorrer do círculo surgem diferentes versões do caso. Até o momento, o foco parece recair sobre o confronto de versões: a facilitadora quer e insiste que a menina, que acredita estar mentindo, fale a verdade ${ }^{61}$.

A menina que está sendo acusada de ter sido a pessoa quem mais falou sobre o garoto, quer levantar outro problema que ela considera importante e a facilitadora corta: -"N.! Agora é o círculo do R., não é o momento, se você quer a gente pede um outro círculo depois! O foco é o problema do R., depois se você quiser a gente faz outro círculo”.

Devido à insistência das partes, a facilitadora resolve tratar do outro problema, de maneira que a menina disse que sentia muito mal e ofendida porque o garoto que pediu o círculo sempre a desrespeitava.

A postura da facilitadora de buscar a verdade, para que ela surja durante o processo, e a sua dificuldade de lidar com uma situação como esta, em que a vítima também agride e aquele que de início agride mostra que sofre agressão também, é bastante elucidativo de como as pessoas ainda refletem sobre estas questões dentro de um registro binário de bem/mal, culpado/vítima, certo/errado.

Todos os alunos gostaram do círculo e todos reclamaram a falta da professora. Um deles disse que sentia aliviado e a facilitadora reafirma a positividade do diálogo.

Algumas conclusões, entretanto, podem ser tiradas do exposto. Em primeiro lugar a facilitadora realmente estava focada em saber quem era o culpado (a). Tanto que ao final do círculo ela disse: - Você viu? Era ela (a menina) que fez isso! Foi só quando eu disse que não ia ter punição que ela contou a verdade.

Mais uma vez vemos aparecer o recurso da utilização do aviso de que o procedimento não resultará em punição, para que aquele que é visto como culpado assuma a culpa por seus atos.

Esta questão é bastante complexa porque se situa num limiar entre dois processos distintos, porém próximos, de culpabilização e responsabilização. A responsabilização é um processo considerado não só positivo pelo paradigma restaurativo, como é requisito fundamental para que o procedimento aconteça. Para que o círculo restaurativo se inicie é preciso que aquele que cometeu o ato conflituoso ou que gerou a situação negativa se responsabilize pelo ato. Já a atribuição de culpa é alvo de críticas pela a justiça restaurativa,

\footnotetext{
${ }^{61}$ Ver nota 59.
} 
mas o limite entre os dois é muito tênue na prática, como se pode verificar da descrição do caso.

Cabe ressaltar, também, que a facilitadora assumiu não dizer a verdade; ela afirmou, no início do círculo, para as crianças que o acordo vai para o Fórum, mas ele não vai, em suas palavras, "é só pra eles verem que é sério".

\subsubsection{Caso n. 6}

Neste dia uma garota chega acompanhada da mãe, ela tem dezessete anos e está cursando o primeiro ano do ensino médio. Relata que ela e a prima procuraram a facilitadora pra fazer o círculo.

Como os demais não chegam para o círculo marcado, a facilitadora pergunta para a mãe e filha se elas querem fazer o círculo em outro dia ou levar para o Judiciário. Elas indagam se isso demoraria e perguntam: "e aí o que acontece?" Ao que a facilitadora responde: "ele vai responder criminalmente por bullying".

Diante da ausência do garoto, que seria o responsável pelo conflito, a facilitadora começa a tentar entrar em contato com ele ou alguém de sua família. Quando retorna diz que falou com o pai do garoto e que este relatou que o filho não tinha avisado ninguém de sua família sobre o caso. Quando voltou do telefonema a facilitadora disse que foi bom ter falado diretamente com o pai porque "pai sempre dá mais firmeza".

A facilitadora admite que ameaçou o garoto, que disse "você vai pro Judicário, eu vou te mandar e você vai ter que responder pro juiz". Seus argumentos, entretanto, não surtiram efeito e uma nova data foi marcada para o círculo.

No segundo encontro marcado a facilitadora entrou em contato com a mãe do garoto, pois o pai disse que não queria colaborar, mandou um bilhete assinado dizendo que não tinha a guarda do menino e que deviam recorrer, portanto, à mãe ${ }^{62}$. Diante da indeferença da mãe também, que disse que não poderia ir porque morava longe (o que de acordo com a facilitadora não era verdade), ela novamente usou o Judiciário como ameaça.

Para tentar convencer a mãe do garoto a comparecer ao círculo marcado, disse ao telefone que ia tentar ser rápida, já que em sua opinião quanto mais rápido o procedimento, melhor, pois quanto mais o círculo demora, mais complicado fica. Isso contraria os pressupostos teóricos que sustentam a justiça restaurativa enquanto um paradigma inovador,

\footnotetext{
${ }^{62}$ Diante desta escusa do pai do garoto é interessante lembrar que a facilitadora tinha dito antes que é sempre
} melhor falar com o pai porque "pai dá mais firmeza". 
de crítica à violência presente nos ritos do sistema de justiça comum. Um dos pilares da mediação é a criação de um espaço para que as partes possam dialogar e encontrar formas mais consensuais de resolver o problema e embora exista hoje uma preocupação com a celeridade do processo diante da grande demanda do Judiciário, em teoria, dever-se-ia aguardar o tempo que fosse preciso para que as partes cheguem a soluções consideradas justas.

Para a parte presente a facilitadora diz que tem a obrigação de enviar o caso para o Fórum, porque houve uma denúncia contra o garoto. De acordo com ela, a vítima fez questão de uma retratação. "O juiz é bem exigente, eu vou mandar pra ele", disse pra tia da menina que estava presente, diante da frustração de mais uma vez terem comparecido ao círculo e a outra parte não. Além disso, a facilitadora faz a comparação, "você é dedicada enquanto a outra mãe é ausente".

Um dado importante é que a escola aconselhou a menina a não fazer o B.O., isso segue de acordo com o principal objetivo do programa, que é a tentativa de resolver esses casos na própria escola para que não cheguem ao Judiciário. A facilitadora parece tentar seguir este objetivo, mas diante do seu insucesso em se impor como uma figura de autoridade e para reafirmar o seu trabalho e o papel do círculo restaurativo como algo importante, não hesita em recorrer à figura imponente do juiz e do Judiciário. A tia que estava presente poderia então ficar tranquila porque o juiz é exigente e ele saberá da ausência e do descaso da outra parte.

Este é um caso interessante, pois ainda que o círculo não tenha sido realizado, mostra todo o esforço que a facilitadora empreende para fazer com que seu trabalho seja reconhecido. Ficam evidentes todos os recursos a que ela usa diante do desdém dos envolvidos, que não reconhecem o círculo como algo legítimo. Percebe-se como a facilitadora busca também no processo um reconhecimento profissional, não se trata somente de desconhecimento em relação à justiça restaurativa, mas de uma desvalorização do papel da facilitadora enquanto uma via de solução dos conflitos tão legítima quanto aquela praticada no Fórum.

\subsection{ALGUMAS CONSIDERAÇÕES SOBRE OS CÍRCULOS OBSERVADOS}

Após a exposição dos seis casos observados, ficam claros alguns pressupostos intrínsecos ao programa de justiça restaurativa analisado. O primeiro deles é o de que as escolas públicas já seriam mais violentas, uma vez que o programa foca no sistema público educacional; em segundo lugar, que estes conflitos são muito simples para se tornarem 
processos judiciais, que só iriam entravar ainda mais os canais oficiais de justiça. É, portanto, uma maneira de evitar que os conflitos saiam da escola e sigam para a delegacia e para o Fórum, ao mesmo tempo em que estes conflitos continuam sob o controle do magistrado, lembrando que de qualquer maneira o papel pedagógico é exercido pela facilitadora.

Muitos autores já problematizaram essa noção de conflitos considerados de menor potencial ofensivo, como Fullin (2011), Azevedo (2001), e Sinhoretto (2011). Azevedo, ao falar da informalização da justiça no Brasil, especificamente sobre os Juizados Especiais Criminais, relata como a insatisfação da vítima é uma consequência negativa não prevista deste movimento. A vítima, cujo objetivo da lei era incorporar ao processo penal, ao constatar a falta de preocupação com a resolução do conflito que está por trás do "delito de menor potencial ofensivo" sente-se impotente e descrente da utilidade do sistema judicial. Já Sinhoretto (2011) problematiza a denominação ao constatar em sua pesquisa como estes conflitos, considerados menos relevantes por estes profissionais, se revelam muitas vezes altamente complexos e não bem administráveis se o procedimento estiver pautado pela celeridade e produtividade.

Sabemos que o principal objetivo dos programas de justiça restaurativa em nosso país é evitar que casos de menor potencial ofensivo cheguem até o sistema de justiça comum. Desde 2005, quando os três projetos piloto foram inaugurados, o foco destes programas e dos demais que têm surgido são os adolescentes e os conflitos relacionados ao contexto escolar. Isto difere dos vários países que vêm utilizando a justiça restaurativa pra diferentes tipos de crime e graus de gravidade, como a Nova Zelândia, Canadá, Austrália ou África do Sul. Nestes países, o uso do modelo restaurativo relaciona-se com a recuperação de formas tradicionais de composição de conflitos e não se limitam ao público adolescente.

Algumas evidências sugerem, entretanto, que esta situação também não é específica do contexto brasileiro. Lindstrom (2003), ao falar do sistema de justiça criminal sueco, afirma que "o objetivo ao ampliar o poder discricionário da polícia desta forma era limitar o tempo que o sistema de justiça gasta lidando com crimes de menor potencial ofensivo e, ao fazer isso, concentrar estes recursos para crimes mais sérios ${ }^{63} "$. (LINDSTRON, 2003, p. 290).

A justiça restaurativa pode ser aplicada a crimes com diferentes graus de potencial ofensivo. Entretanto, quando passa a ser utilizada na mediação de conflitos, o que se tem geralmente é uma seleção de crimes considerados mais "leves". Nesse âmbito, a questão da

\footnotetext{
${ }^{63}$ Tradução livre da autora, no original: "the object of widening the police's discretionary power in this way was to limit the time the justice system spent dealing with very minor offences and, in so doing, to concentrate these resources on more serious crime".
} 
utilização dos programas restaurativos para casos de menor gravidade pode se constituir num paradoxo, porque quanto menor a necessidade de reintegração social está presente, mais a justiça restaurativa é recomendada. Além disso, se for aplicada em casos em que sem ela a justiça criminal não trabalharia, corre-se o risco de que, não conseguindo chegar a uma conclusão, eles sejam encaminhados para o sistema penal convencional voltando ao velho problema de sobrecarga (JACCOUD, 2005).

A crítica desta autora é bastante pertinente para pensarmos o caso brasileiro, pois, como vimos, o principal propósito dos programas em nosso país é evitar o encaminhamento de casos de conflitos escolares para o Judiciário.

Como bem lembra Pallamolla (2009): “Quando não existem regras claras sobre quais casos são passíveis de encaminhamento, a tendência é que juízes, promotores públicos e a polícia encaminhem apenas casos de pouca relevância, buscando não reduzir seu campo de atuação".

Outra consequência deste quadro é que longe de empoderar o modelo restaurativo, o procedimento de enviar para as iniciativas apenas ou prioritariamente casos de menor gravidade acaba reforçando a marginalidade da justiça restaurativa frente aos canais oficiais de justiça.

Além disso, é possível estender o argumento e pensar em que medida é um movimento duplo em que o juiz pode delegar os casos que não considera fazerem parte de sua expertise para outros profissionais, situados numa posição inferior da hierarquia profissional. Ao mesmo tempo, se existe esse descaso com estes casos rotulados de menor potencial ofensivo, parece haver, também, um objetivo de manter um certo tipo de controle sobre estes mesmos casos.

\subsection{1 "Por que você faz isso com a sua família?"}

Essa frase foi dita no primeiro círculo observado; ela foi proferida pelo professor que acusava o aluno de ameaçá-lo e sintetiza todo o momento de constrangimento pelo qual passou este aluno. Neste primeiro caso relatado, vimos como a atitude defensiva do aluno e os elementos disciplinadores dirigidos ao mesmo compunham a cena. Não cabe aqui apontar se ele realmente se comportou de maneira indevida com o professor ou não, o que importa para a análise é verificar como aquele foi o momento em que este professor pôde resgatar toda a sua 
autoridade; ele viu naquele procedimento espaço para exercer seu papel de educador que provavelmente não estivesse conseguindo em outros contextos.

Verifiquei também, em outros momentos, vários julgamentos de valor proferidos pelas facilitadoras: "Olha eu não te conheço, estou te conhecendo agora, mas você me parece ser mais agitadinha...", "você parece ser um menino bom", "você é dedicada enquanto a outra mãe é ausente".

Diversos autores já aludiram para os custos que uma resolução informal poderia trazer como Garapon (1997) e Miraglia (2005).

Garapon mostra como os rituais informais podem ter dificuldades para assegurar o equilíbrio entre as partes, justamente porque, ao tentar desvincular-se do ritual formal por considerá-lo violento, acaba abrindo as portas para que outros tipos de violência possam tomar lugar.

Já Miraglia, a partir de um estudo etnográfico nas Varas Especiais da Infância e Juventude, aponta como, nas audiências envolvendo jovens em conflito com a lei, as relações são marcadas essencialmente pela assimetria entre os atores e pela reafirmação constante de hierarquias - um quadro que se aproxima bastante das situações verificadas nos círculos em São Caetano do Sul.

Castanho e Oliveira; Pavez; Schilling (2002) argumentam na obra intitulada Reflexões sobre justiça e violência: o atendimento a familiares de vítimas de crimes fatais que o tipo de prática atrelada à justiça restaurativa, ao tentar exercer uma coerção sobre o ofensor quando conclama a participação de todos os envolvidos numa conferência, supõe que a comunidade seja um sistema único e abrangente de valores. Contrariamente a esta situação, o modelo de justiça criminal ao menos conseguiria estabelecer padrões de comportamento e julgamento sem exigir que haja estrita conformação aos seus valores.

São situações como as descritas anteriormente, de constrangimento de uma das partes envolvidas ou até mesmo das duas partes, que nos fazem refletir sobre as possibilidades de aplicação da justiça restaurativa em espaços marcados por hierarquias e relações desiguais de poder, como é o caso da escola.

Melo (2006) argumenta em artigo que a escola seria um lugar neutro e por isso o escolhido para a realização dos círculos, mas o presente texto vai na direção contrária e tenta problematizar esta afirmação a partir do que o material empírico trouxe.

É possível refletir sobre como a justiça restaurativa, com todo seu arcabouço teórico filosófico voltado para a não punição e para a horizontalização de relações, pode ser aplicada 
em ambientes marcados por relações assimétricas como acontece com as escolas, que têm sido o lugar privilegiado de aplicação do modelo.

Uma entrevistada, integrante da ONG CECIP (Centro de Criação de Imagem Popular, Rio de Janeiro/RJ), que participa de capacitações, afirmou em nosso encontro que resgatar o lugar do professor é um objetivo do programa. Ao mesmo tempo, ela também ponderou como muitas vezes nas escolas se depara com algumas resistências, alguns professores dizem "eu não vou trabalhar mais pro juiz trabalhar menos".

Podemos pensar, também, em que medida o ponto forte da justiça restaurativa se transforma simultaneamente no seu ponto mais frágil, mais vulnerável; pois, na medida em que almeja restaurar as relações sociais rompidas com o ato conflituoso, ela pode juntamente a isso restaurar as relações de poder que estão imbricadas nestas relações sociais que quer restabelecer.

No mais das vezes, é lícito dizer que a justiça restaurativa tem se constituído mais como um espaço de restabelecimento de autoridades do que de autonomia das partes para dialogarem e construírem soluções de comum acordo. No caso do primeiro círculo descrito, vimos como o professor exerceu um papel moralizante sobre o aluno. Do mesmo modo, pudemos também constatar nos demais casos o empenho das facilitadoras em tentar se colocar como uma figura de autoridade em face do descaso com que alguns usuários tratam o procedimento.

Algumas características do círculo restaurativo na cidade observadas como: a preocupação com a conduta do adolescente, seu rendimento escolar, o envolvimento anterior em conflitos, enxergar o momento como uma oportunidade de educar o jovem são alguns dos aspectos que diversos estudos, como o já citado anteriormente de Miraglia (2005), encontraram quanto atentaram para as Varas de Infância e Juventude.

Cabe questionar, portanto, em relação a quê o modelo restaurativo é alternativo? Isso porque, em muitos momentos, o que parece haver é uma mimetização do modelo informal em relação ao seu par institucional, ao tipo de justiça a que está ligada, que neste caso é a justiça da área da infância e juventude.

Parece, assim, que a justiça restaurativa reproduz, num ambiente de informalidade, práticas que estão arraigadas na condução dos procedimentos na justiça comum. É um modelo alternativo, pois não ocorre no Fórum e não conta com a presença do juiz, mas é informado por práticas e discursos que não estão previstos pelo respaldo teórico que inicialmente o fundamenta; não obstante, contrasta fortemente também com o ideário acerca da justiça restaurativa que os profissionais envolvidos com os programas sustentam. 
O próprio ideal de autocomposição do conflito pelas partes, como respaldado pela teoria da justiça restaurativa, fica comprometido se a mediação, na prática, está orientada pelo tom pedagógico e disciplinador comum às Varas de Infância e Juventude. Perde-se, dessa forma, todo o conteúdo potencialmente transformador que o modelo propõe.

Salm (2012) acrescenta que: “...entende-se que com a intervenção estatal devem ser tomados diversos cuidados, para que estes espaços não sejam colonizados pelas dinâmicas burocratizadas que tem marcado a procedibilidade estatal de produzir (in)justiça (des)comprometida oficializada”. Esta também é uma preocupação patente na literatura a respeito da justiça restaurativa, a de que as iniciativas ou programas que a utilizam precisam atentar para os princípios orientadores que fazem dele justamente um procedimento alternativo, para que não sejam colonizados por experiências já enraizadas nas estruturas do sistema de justiça oficial.

Faisting (1999) ao falar dos Juizados Especiais expõe que:

Ao serem colocados diante de situações que envolvem relações sociais cada vez mais dinâmicas e complexas, os juízes apostam na conciliação como solução para muitas demandas, mas o fato é que eles não foram preparados para serem conciliadores, uma vez que são formados e socializados em uma cultura institucional baseada no poder de decidir. O risco, portanto, é o predomínio da lógica formal de decisão num ambiente no qual deveria vingar a lógica informal da mediação. (FAISTING, 1999, p. 50)

A novidade em relação ao que Faisting (1999) aponta é que esta impregnação do modelo informal pelo formal não ocorre apenas se o condutor do procedimento for um profissional do mundo do Direito, cujas redes e sociabilidades situam-se no mundo jurídico. Como se pode inferir do trabalho de campo exposto, leigos também tendem a trazer para o procedimento alternativo aspectos característicos dos rituais formais. Estes são os novos experts, que, atuando em parceria com os tribunais, estão fazendo do modelo alternativo mais um apêndice do modelo de justiça oficial.

\subsubsection{O papel das escolas e o problema dos Boletins de Ocorrência}

Interessante notar que nos círculos assistidos, foi muito ressaltado o fraco papel da instituição da escola como mediadora na administração de conflitos que anteriormente ficavam circunscritos ao ambiente escolar. Se não foi a principal ideia norteadora do projeto 
de São Caetano do Sul, pelo menos uma das mais importantes era tentar "resolver os conflitos escolares no próprio ambiente da escola". Contudo, o que se verifica é um processo inverso, em que os conflitos (professor $\mathrm{x}$ aluno ou aluno $\mathrm{x}$ aluno) saem dos limites da escola e vão para as delegacias e Fórum - é o juiz quem indica os casos a serem resolvidos pelo programa de justiça restaurativa - voltando, então, para o lugar de onde partiram.

No documento intitulado: Proposta de trabalho para os projetos de justiça restaurativa e comunitária de São Caetano do Sul em 2007. (Documento de 15/06/2007) dizse o seguinte:

\footnotetext{
"A existência de espaços comunitários de resolução de conflitos em S. $\mathrm{C}$ do Sul tem garantido, assim, não apenas a possibilidade de procura espontânea pela comunidade de meios de resolução de seus conflitos, mas também uma maior parceria entre comunidade e instituições, seja a escola, seja a guarda e a polícia, seja a justiça”.
}

Não existe, entretanto, essa busca espontânea pelo programa por parte da comunidade. Assim, ainda que as pessoas possam procurar espontaneamente o programa de justiça restaurativa, a grande maioria dos casos atendidos hoje já vem do modelo de justiça comum, resultantes de Boletins de Ocorrências que são incentivados pelas diretorias de escola, médicos, policiais, delegados, como foi possível observar no trabalho de campo realizado.

Um dos facilitadores relatou: "hoje é muito fácil fazer BO, é por isso que fez o projeto piloto, porque tem muito BO nesse bairro". Esse quadro parece indicar respostas à questão que se coloca, no caso: se a justiça restaurativa poderia ser entendida como uma via de aumento do acesso da população à justiça (justiça entendida aqui num sentido mais amplo); já que ela tenta evitar o encaminhamento de casos considerados de menor potencial ofensivo aos trâmites oficiais.

O foco do projeto na cidade reside, portanto, no espaço vazio que a escola tem criado com a sua "neutralidade", diante da crescente marginalização do espaço.

Almejava-se resolver conflitos escolares dentro do ambiente escolar, tomando como fato de que grande parte dessas desavenças chega aos tribunais sem que precisasse sair dos muros da escola, ajudando a entravar os canais formais de acesso à justiça. Ao mesmo tempo, o dado colhido, de que ainda existia uma postura dentro do programa de justiça restaurativa de São Caetano do Sul, de oficiar os resultados de um processo que tem como premissa ser um tipo de mediação informal, vai contra seus objetivos de maior celeridade, informalidade, não ajudando a desafogar o sistema de justiça comum como se imaginava. Assim, muitos casos que antes não chegavam até o sistema formal de justiça e eram administrados em outros 
espaços agora passam por ele. É uma forma de controle sobre um tipo de resolução de conflitos incipiente ainda no Brasil.

Jaccoud (2005) também alude para o fato de que a justiça restaurativa, quando utilizada com a pretensão de reduzir o uso do sistema penal pode ter com isso um efeito perverso, se aplicada a situações e clientelas que de outra forma não ingressariam no sistema penal. Tais casos, que normalmente receberiam apenas uma advertência policial ou seriam redirecionados a outros setores que não o criminal, ao serem levados para a justiça restaurativa correriam o risco de ingressar no sistema criminal se o acordo não for alcançado durante o procedimento restaurativo, ou do acordo estabelecido não ser cumprido. Este seria mais um aspecto a ser considerado pelos incentivadores do modelo.

\subsubsection{Quando a justiça oficial vira uma ameaça}

Pela observação presencial de círculos restaurativos em São Caetano do Sul, pôde-se notar sempre um discurso das facilitadoras, logo antes de começar o procedimento, dirigido aos participantes, e, sobretudo, ao ofensor, que diz que a participação no círculo é uma chance que lhe foi dada (pelo juiz), a ser aproveitada. Nos casos envolvendo adolescentes, é sempre pontuado como positivo o uso do procedimento restaurativo, em razão de ele não resultar em registro na ficha criminal ${ }^{64}$. Como vimos, chega-se a afirmar, inclusive, que caso se envolvam novamente em conflitos as coisas podem ser diferentes, o juiz pode não mais levar a situação para o projeto de justiça restaurativa e conduzir nos trâmites tradicionais.

Segundo a facilitadora, eles iriam verificar se os adolescentes se envolveram em conflitos antes e se confirmada a reincidência, então, provavelmente, não poderiam mais resolver os problemas de acordo com a justiça restaurativa, teria que ser segundo as formas convencionais, que poderiam resultar em penas de medidas socioeducativas, pagamento de cestas básicas, trabalho voluntário ou internação na Fundação Casa, o que poderia ser, em sua opinião, o pior desfecho para eles, tendo em vista a atual situação de crise da instituição. Logo, o destino deles ficaria a cargo da decisão do juiz.

As constantes alusões ao modelo oficial de justiça, feitas durante o círculo, são uma estratégia empregada pelas facilitadoras para tentar dar mais validade ao procedimento informal. Como elas de antemão já esperam maior desconfiança da população pelo fato de a

\footnotetext{
${ }^{64}$ Cabe aqui uma observação em relação à proclamada voluntariedade dos participantes. Ou seja: é voluntário realmente se a justiça restaurativa sempre se apresenta como a opção mais vantajosa?
} 
justiça restaurativa acontecer num ambiente escolar e sem a presença de autoridades, desde o início ressaltam que tudo será relatado ao juiz. Interessante observar, também, como o modelo oficial de justiça acaba se tornando uma ameaça no discurso das facilitadoras, já que o argumento mobilizado por elas é o de que seria preciso aproveitar a chance da justiça restaurativa; ou seja, devem acatar todos os conselhos que receberam, porque se voltarem a cometer alguma infração podem, na próxima vez, responder em juízo.

Porém, quando a facilitadora frisa ao adolescente que o círculo restaurativo é uma chance de resolver as coisas - numa primeira vez - de forma mais branda e que num próximo conflito o procedimento será diferente, ela não marca uma ruptura com os meios oficiais de administração de conflitos, pelo contrário, o discurso ressalta a sua continuidade. O paradigma restaurativo traz consigo um embasamento teórico-filosófico já extenso e reconhecido, que por si só seria capaz de angariar maior adesão, mas essa expertise não é mobilizada durante os círculos; de maneira diversa, os facilitadores procuram sempre ressaltar que a justiça restaurativa é acompanhada de perto pela autoridade oficial, acompanhamento que é traduzido na sua institucionalização, vinculação ao sistema judiciário e condução feita por magistrados.

Como argumentam Raupp e Benedetti (2007), manter a aplicação da justiça restaurativa fortemente atrelada ao sistema oficial e utilizá-la para dar novo significado ou qualificar a medida socioeducativa, inviabiliza o importante contraponto que ela pode fazer ao modelo retributivo; ou seja, funcionaliza-se a justiça restaurativa, transformando-a em apenas mais um instrumento a serviço do sistema de justiça criminal.

É possível concluir, a partir das observações do trabalho de campo, que antes de ser uma forma alternativa de administração de conflitos, a justiça restaurativa está sendo praticada como um procedimento, uma etapa, no interior da forma judicial clássica de administração de conflitos, voltada ainda para a punição do indivíduo infrator.

\subsubsection{Presenças e ausências}

A partir dos casos descritos, verificou-se, também, que a ausência física do juiz no procedimento não impede que ele esteja simbolicamente presente, pois é, o tempo todo, uma figura a quem a facilitadora recorre para tentar dar mais legitimidade ao ritual informal. 
Não raro, entretanto, essa tentativa de reafirmar o peso do círculo restaurativo, através das constantes alusões à figura do juiz, não surte efeito e é preciso remarcar o procedimento devido à ausência de uma das partes.

Cabe ressaltar, portanto, que a ausência de uma das partes é algo bastante recorrente, seja por medo da repreensão, no caso de se ausentar a parte acusada, ou por realmente não darem muita importância ao modo alternativo de gestão de conflitos, que é uma possibilidade bastante plausível, visto algumas posturas e falas de descaso observadas nas idas à campo.

Como foi relatado por um interlocutor, em uma das vezes em que o círculo não aconteceu, por conta da ausência do rapaz acusado, a facilitadora admitiu que o ameaçou dizendo: "você vai pro Judicário, eu vou te mandar e você vai ter que responder pro juiz". Diante da segunda ausência (o círculo foi remarcado e novamente não compareceram o rapaz ou alguém de sua família), a facilitadora diz para a parte que estava presente: “O juiz é bem exigente, eu vou mandar pra ele", numa tentativa de amenizar a frustração de mais uma vez terem comparecido ao círculo que não aconteceu devido à ausência da outra parte.

Quando indagadas a respeito dos resultados do programa na cidade, duas facilitadoras disseram que ainda não recebam em mãos dados quantitativos como índices, porcentagens, estatísticas - elas percebem os efeitos positivos de seu trabalho na própria interação com a população atendida. Elas frisam que sempre recebem comentários elogiando a forma de composição restaurativa, em contrapartida, é preciso fazer a ressalva de que em diversos momentos do trabalho de campo notou-se algum grau de insatisfação da população em participar do procedimento. Entre as razões, aponto o fato de a maioria dos casos serem justamente conflitos escolares considerados pelos mesmos como casos de menor importância.

Além disso, existe também o desconforto de ter que deslocar até o local, que não tem a legitimidade do Fórum e muitos precisam faltar ao trabalho para acompanhar seus filhos. Este quadro acaba por gerar comentários como o seguinte, feito durante a realização de um círculo assistido: “ah, se tiver que vir de novo eu não venho mais não!” Em muitos casos, é preciso realizar mais de um círculo, isso pode acontecer pelo tipo de conflito, sua gravidade ou pela ausência dos envolvidos, o que é bastante comum, e as pessoas se incomodam com a possibilidade de terem de ir mais de uma vez à escola. 


\subsubsection{A percepção dos usuários: alternativo ou subalterno?}

Já foi mencionada anteriormente a percepção de desdém e perda de tempo que é comum entre os usuários - alguns acham muito estranho que a administração do conflito judicial seja feita no ambiente da escola, por pessoas alheias ao mundo jurídico. Há muitas ausências registradas, pessoas que não comparecem ao círculo quando chamadas, não vendo, portanto, a possibilidade de administrar o conflito a contento por essa via. Outros comparecem externando sua estranheza e sua pouca disposição de se deslocar para ter que administrar problemas tão simples. Como anotado, os pais dos adolescentes chamados tendem a considerar um exagero que os conflitos escolares entre os adolescentes, ou entre eles e os professores, transbordem os muros da escola, acabem no Fórum e dali para uma terceira instância ainda, que é o círculo restaurativo.

Alguns dos pais com os quais tive contato entendiam, portanto, que o procedimento restaurativo, ao invés de ser uma simplificação e facilitação para a resolução do problema, é na verdade uma complicação desnecessária, pois tudo poderia ter sido resolvido dentro da escola mesmo, talvez com a participação deles. Para eles, é difícil enxergar que a justiça restaurativa seja mesmo um benefício para o adolescente acusado, termos nos quais os facilitadores procuram conseguir a adesão dos pais ao método.

Ao contrário de outras iniciativas, em que a população procura de forma voluntária ter acesso aos canais extraoficiais de justiça para resolver seus conflitos (como acontece no CIC, por exemplo, como demonstrado por SINHORETTO, 2011), no programa de Justiça Restaurativa em São Caetano do Sul os envolvidos no problema são intimados a participar. Todo embasamento teórico que fundamenta a justiça restaurativa não é mobilizado para conquistar novos participantes; de maneira diversa, os casos são selecionados de acordo com a avaliação que os profissionais do direito, juiz(a) ou promotor(a), fazem.

Segue um excerto do depoimento de uma adolescente, vítima de agressão na escola, durante a realização do círculo restaurativo, no momento em que relata como foi feita a proposta para participar do programa:

Adolescente: "Aí a promotora perguntou: o senhor (rapaz) quer dar como encerrado o caso e levar pro conselho restaurativo ou prolongar aqui. Aí ele falou assim: Não, não quero nenhum dos dois. Aí ela falou: você não tem que querer alguma coisa aqui, você tem que escolher: conselho restaurativo ou levar adiante? Ele: conselho restaurativo (com ar de deboche)". 
Cabe apontar ainda que os usuários do programa percebem, portanto, que ingressaram em um modelo subalterno em relação ao modelo oficial, ainda que compareçam e participem. São comuns os comentários de desprezo em relação ao tipo de procedimento: por ser na escola, não contar com a participação do juiz, ser longe, terem que faltar de compromissos para participar, etc. Ao mesmo tempo, é preciso ter em conta que os envolvidos na aplicação do modelo ressaltam sempre os aspectos positivos proporcionados pelo programa, como se fossem constantemente impelidos a responder às críticas e ao desdém com que alguns usuários tratam inicialmente a situação do círculo restaurativo.

\subsubsection{A busca pela verdade}

Em alguns dos casos descritos, vimos como é comum a utilização do aviso de que o procedimento não vai resultar em punição ou castigo, como forma de fazer com que aquele que se acredita ser o culpado pelo conflito admita seu erro. A afirmação de que não vai haver julgamento parece ser uma estratégia empregada pelas facilitadoras para conseguir extrair do círculo a verdade que elas acreditam estar obscurecida pelas diferentes versões.

Nesse caso, argumento como isto pode ser interpretado como sendo mais uma característica trazida do processo formal para o informal, e mais ainda, como isso se relaciona com nossa tradição inquisitorial, comum à Civil Law. A emergência da verdade, que é tão pretendida no ritual de composição do conflito, surge como um momento da catarse nos processos restaurativos observados e podemos pensar em que medida este aspecto não está enraizado no Direito brasileiro.

Garapon e Papapoulos (2008) fazem uma análise comparativa de duas diferentes tradições do direito, a que eles denominam culturas jurídicas, o que é bastante interessante para a presente pesquisa. A análise dos autores, que busca nas origens do pensamento religioso as causas das principais diferenças que marcam a common law e a civil law, pode ajudar a esclarecer o argumento proposto, ou seja, de como a busca pela verdade se relaciona a uma dimensão mais ampla ligada à nossa tradição no direito brasileiro.

Os autores empregam o conceito de cultura jurídica, reproduzido aqui, tentando romper com sistematizações um tanto rígidas empregadas muitas vezes pela sociologia do Direito. Nesse sentido, a ideia de uma cultura jurídica parece ser a mais adequada para a realização de um exercício de compreensão de marcas que diferenciam dois sistemas de 
justiça diversos. O emprego deste conceito é uma tentativa de captar a dinâmica dos processos sociais, que se desenvolvem num espaço e tempo e que, retomando Foucault, produzem verdades: "a cultura (...) é a atenção dada a uma atitude profunda, ainda mais plena de significados em razão de não termos consciência de estarmos a ela sujeitos”. (GARAPON; PAPAPOULOS, 2008, p.8)

Os autores acreditam, portanto, que as origens da profunda divergência entre a common law e a civil law devem ser buscadas sobretudo na religião. Leia-se neste caso o protestantismo e as relações que podem ser traçadas com a common law, que diz respeito aos Estados Unidos e Inglaterra (tradição anglo-saxã) e as religiões de matriz católica, concernentes à civil law, ou a chamada tradição do "continente", mas que se atém mais especificamente ao caso da França, de onde vem nossa origem no Direito brasileiro.

Embora interessante, a dimensão religiosa abordada pelos autores extrapola os limites propostos por esta pesquisa. Não nos aprofundaremos nesta questão e nos limitaremos em apontar algumas das diferenças entre os dois tipos de culturas jurídicas para ilustrar o argumento proposto. Cabe lembrar, entretanto, como estas esferas, a justiça e a religião, são conectadas.

Durkheim (2002), autor clássico da sociologia, considerado um dos autores que se preocuparam com a sua institucionalização enquanto uma área que pudesse ser reconhecida com o status de ciência, também trabalhou questões da sociedade e o Direito; mais ainda, estabeleceu relações entre o Direito e a religião. Durkheim refere que a repressão do crime exprime algo de "sagrado". Mais especificamente, ele argumenta que "o direito penal não só é essencialmente religioso em sua origem, como ainda conserva uma certa marca de religiosidade" (DURKHEIM, 2002, p.223).

David Garland (2008), autor contemporâneo e nome expressivo no campo da sociologia da punição, retoma Durkheim e seu conceito de consciência coletiva: para ele, esta consciência seria, segundo Durkheim, protegida por um código estrito de direito penal que evoca emoções profundas e um sentido do sagrado. Dessa forma, continua o autor, em um mundo de diversidade secular, a punição continua a proteger uma esfera residual de valores sagrados e tira sua força e significação deste fato. Assim, os rituais da justiça penal, tais como a audiência pública, o pronunciamento da pena e a sua execução, nada mais seriam então do que a formalização de uma consciência coletiva, ou seja, esses procedimentos dariam uma expressão formal aos sentimentos da coletividade ferida pelo crime.

A despeito do fato de que teorias de autores clássicos do pensamento social, como Durkheim, tenham sido revisitadas, ou mesmo criticadas, fica clara a importância que tal tema 
assume nas ciências sociais e, mais especificamente, no subdomínio da sociologia. As relações da sociedade e o Direito, ou do Direito e o pensamento religioso estavam presentes desde o início do desenvolvimento desta área de conhecimento.

Garapon e Papapoulos (2008) argumentam que as concepções sobre o que é a verdade, de onde ela provém e a relação que o indivíduo estabelece com o universal diferem totalmente no Catolicismo e no Protestantismo, e, mais precisamente, no Puritanismo americano, e isso incide diretamente sobre a construção dos dois modelos jurídicos.

Em relação à civil law, argumentam os autores que nesse universo do Catolicismo, onde a Igreja, com toda a sua autoridade doutrinal ocupa um papel central, a hierarquização garante a dominação intelectual da instituição, de maneira que suas verdades dogmáticas e as normas morais são dadas do "alto", verticalmente. Da mesma forma, a conformação jurídica resultante deste tipo de sociedade (sob o jugo religioso) produzirá uma relação particular com o universal, por intermédio da lei que aqui é tida como sacralizada porque proviria, em última instância, do representante na terra da vontade divina, o que lhe asseguraria uma grande autoridade e exterioridade em relação à vida. Munida, portanto, de uma grande carga simbólica, a lei é sempre objeto de um temor reverencial:

O juiz, nessa cultura, não é visto como um mediador entre uma lei soberana e uma realidade social complexa, mas como um representante do Estado considerado como fonte última e única verdade à imagem da Igreja, de que ele é o prolongamento simbólico (GARAPON; PAPAPOULOS, 2008, p.102).

A common law, modelo jurídico dos EUA e Inglaterra, se centra muito mais num processo do que numa busca mítica pela verdade, tal como ocorre com a civil law. A verdade em si mesma não é o mais fundamental para a cultura jurídica anglo-saxã, mas o método através do qual se pensa chegar até ela. Sendo assim, todo o processo jurídico se transforma numa complexa estrutura na qual as partes podem negociar (ao menos teoricamente) num mesmo patamar de igualdade, com amplas possibilidades de mobilizar recursos, estratégias e discursos para o confronto de versões, do qual apenas um relato sairá vitorioso.

Garapon e Papapoulos resumem bem a questão ao referirem que: "Se o sonho do procedimento de inquirição, sobretudo o francês, é fazer 'eclodir a verdade', o objetivo da cultura contraditória é mais o de fazer com que os depoimentos se fundam, sejam postos em concorrência para que triunfe o mais conveniente" (GARAPON; PAPAPOULOS, 2008, p.106). 
Podemos então dizer, sinteticamente, que enquanto a cultura jurídica romanista procura a substância da verdade tentando estabelecer um relato oficial por meio da decisão judicial do magistrado, a cultura jurídica da common law, ao contrário, organiza o confronto de duas versões para fazer triunfar publicamente o relato mais verossímil.

Como bem lembram os autores, o ideal de verdade é o mesmo em ambos, mas os modos de produção da verdade diferem substancialmente nos dois tipos.

\section{A SITUAÇÃO DAS TRÊS OUTRAS REGIÕES}

Embora São Caetano do Sul (SP) tenha sido a localidade sobre a qual a pesquisa mais de debruçou, vale a pena relatar um pouco da situação de três outras regiões do estado de São Paulo no que toca à justiça restaurativa. Isso permitirá observar a variedade de situações concernentes à justiça restaurativa nesta região. Se em Campinas e Heliópolis as iniciativas não tiveram continuidade, São José dos Campos, por outro lado, vem investindo na criação de um programa nos moldes do programa baseado em São Caetano do Sul, ou seja, apostando na associação entre justiça para crianças e adolescentes e o sistema público educacional.

\section{A situação de Campinas:}

No município de Campinas, região do interior do estado de São Paulo, escolas da rede pública de ensino foram capacitadas para trabalharem com a justiça restaurativa. Tive a oportunidade de visitar uma destas escolas, localizada na periferia da cidade, muito afastada e conhecida por ser uma região sob domínio de uma organização criminosa. Nesta visita tive também a oportunidade de conversar com o diretor da instituição e conhecer um pouco mais tanto da rotina da escola quanto do trabalho do professor mediador.

Esta escola, que fez parte do projeto que visava implantar o modelo da justiça restaurativa no município, é muito grande e atende crianças do ensino fundamental e médio em todos os períodos.

Segundo o relato do diretor, que demonstrou bastante receio na entrevista e não autorizou o registro da conversa com um gravador, há mais ou menos seis anos atrás entraram em contato com ele para falar a respeito da proposta da justiça restaurativa. Durante esta conversa, na qual lhe fizeram a proposta de instauração do modelo alternativo na escola, o 
diretor me disse que lhe afirmaram em algumas oportunidades que os conflitos das escolas deviam permanecer nas escolas, ideia bastante comum entre os propositores dos programas, como já pudemos observar anteriormente.

$\mathrm{Na}$ época teriam sido selecionadas cerca de dez escolas da Diretoria Oeste (aquelas que apresentam maiores níveis de vulnerabilidade) e a iniciativa também teria contado com o envolvimento direto do juiz da Vara da Infância e Juventude da cidade. A capacitação dos diretores destas escolas aconteceu em São Paulo e foram seis dias de capacitação no total.

Depois dessa primeira etapa foram realizadas mais capacitações em Campinas também. Como relatado durante o encontro, parecia haver uma divisão entre estado e município: no município havia possibilidade de remuneração, enquanto que no estado não, e isso, em sua opinião, foi um problema, um divisor de águas no processo. Cabe pontuar aqui que o trabalho voluntário é uma questão que aparece subjacente o tempo todo no meu trabalho de investigação. Os potenciais profissionais, neste caso os professores, a trabalharem com a justiça restaurativa, não querem aumentar sua carga horária ou carga de trabalho sem serem remunerados para isso.

Quando questionado acerca do motivo de o programa não ter conseguido se estabelecer ali mais especificamente, ou em Campinas como um todo, o argumento fornecido pelo diretor foi o de que o círculo não funciona na prática porque demanda tempo (o procedimento é composto de três etapas: pré-círculo, círculo e pós-círculo). De acordo com ele, às vezes eram até quinze casos de conflitos para serem resolvidos em um só dia, uma grande demanda em sua opinião. A sugestão que o diretor deu para os organizadores do projeto foi a de que se remunerasse o mediador como um professor "reforço" e funcionários da secretaria de educação lhe respondiam dizendo que isso não era possível.

É interessante observar como em meio às discussões sobre as possibilidades de aplicação da justiça restaurativa no Brasil, que acontecem desde 2005 quando os projetos piloto começaram a funcionar, surgiu recentemente a figura do professor mediador. A instituição deste novo personagem nas escolas ocorreu quando a Secretaria de Educação do Estado de São Paulo, em 2010, tomou a iniciativa e estabeleceu o projeto Professor mediador escolar e comunitário. Em minha visita à escola em Campinas pude verificar um pouco do trabalho que o professor mediador exerce naquele local e, ao contrário do que argumentam alguns defensores da justiça restaurativa, que consideram a introdução dessa figura nas escolas uma vitória do modelo no país, eu não consegui verificar em que medida o trabalho deste professor mediador se aproxima da proposta da justiça restaurativa. 
O professor mediador na escola visitada tinha uma sala própria para seu trabalho, mas ele ali não realiza círculos restaurativos, ou qualquer outra prática que se aproxime da proposta do paradigma restaurativo. Como pude notar, ele apenas encaminha cartas endereçadas aos pais de alunos que se comportaram mal, bilhetes avisando de suspensões ou situações semelhantes e também aplica um pequeno sermão corretivo naqueles alunos que causaram algum problema de acordo com seus professores, que encaminham esses alunos para sua sala. A introdução do professor mediador neste ambiente é visto como positivo pelos demais funcionários da escola já que ele centraliza em suas mãos funções de repreensão que antes ficavam dispersas pelo local, sendo ora aplicadas pelo professor na sala de aula, ora pelo diretor ou vice-diretor, ou até mesmo pelo inspetor geral.

Portanto, diferentemente do discurso do juiz que era responsável pelo programa em Heliópolis e da capacitadora partícipe da ONG CECIP, que me afirmaram em entrevistas que consideravam o professor mediador como mais uma das muitas vitórias da justiça restaurativa no país, o pessoal que coordenou a proposta em Campinas não interpretou o fato da mesma forma. Também é interessante notar que a mesma integrante do CECIP foi responsável pela capacitação dos professores mediadores, mostrando como essa rede é bastante sólida no campo.

Obtive também acesso a alguns documentos da escola em relação à iniciativa de justiça restaurativa. No projeto inicial, que previa a implantação do modelo na localidade, é possível verificar que a direção da escola, através de documento oficial com aval do governo do estado de São Paulo, através da Secretaria de Estado da Educação (Diretoria de Ensino da Região de Campinas Oeste) convocou oficialmente cinco professores, para participarem do curso de capacitação do projeto de Justiça Restaurativa. Foi organizado também um curso de capacitação para os seguintes atores da rede de atendimento: Judiciário, Ministério Público, programas de medidas sócio educativas e 6 escolas públicas (pilotos).

Toda essa mobilização aconteceu no ano de 2008. O workshop aconteceu no dia 7 de março daquele ano e contou com apoio com a Diretoria de Ensino Campinas Oeste e Conselho Municipal dos Direitos da Criança e do Adolescente:

\footnotetext{
"No período entre março e outubro de 2008 a rede de Medidas Socioeducativas em meio aberto e fechado, a Vara da Infância e Juventude de Campinas, 4 escolas estaduais e 2 municipais terão a oportunidade de fazer um curso de capacitação para a implantação da justiça restaurativa no município de Campinas".
} 
Participaram da capacitação, portanto, representantes de diversos órgãos que tratam da questão da infância e adolescência no local. Os responsáveis pelo projeto foram provenientes da Vara da Infância e Juventude de Campinas e do Conselho Municipal de Direitos da Criança e do Adolescente do município.

A experiência que baliza a iniciativa, como constantemente reportado no projeto é a do município de São Caetano do Sul, diversas vezes citado no texto.

Na redação do projeto constam também as justificativas para o programa:

"Acreditanto que a violência é um fenômeno que decorre não apenas de fatores estruturais de ordem socioeconômica, mas também de determinantes culturais e psicossociais, o CMDCA e a VIJ de Campinas vêm buscando formas de apoiar as escolas para que elas posssam transformar-se em espaços democráticos de construção de uma cultura da não-violência e de uma educação para a sustentabilidade".

"Assim, o CMDCA e a VIJ de Campinas decidiram implementar, junto a 20 educadores de 5 escolas da Rede Pública de Educação, sendo uma de cada região administrativa de Campinas, Juiz, Defensor Público, técnicos da VIJ de Campinas, membros da Comissão de Medidas Sócio Educativas do CMDCA e Conselhos Tutelares, o Projeto Justiça \& Educação -Novas Perspectivas".

Fica claro como o foco do projeto, do mesmo modo como acontece em São Caetano do Sul, são as escolas, na tentativa de evitar judicialização destes conflitos. Como objetivo geral no projeto definiu-se: implantar a Justiça Restaurativa através da realização de círculos restaurativos como método de resolução de conflitos no Sistema Judiciário e Escolas.

Os parceiros do projeto citados no documento são: Vara da Infância e Juventude, Ministério Público, Defensoria Pública, Conselho Municipal da Criança e do Adolescente Comissão de Medidas Socioeducativas, Diretoria de Ensino Campinas Leste, Diretoria de Ensino Campinas Oeste, Secretaria Municipal de Educação, Secretaria de Segurança Pública, Fundação Casa, OAB, Conselhos Tutelares, Centro de Defesa de campinas (sendo que alguns participam como colaboradores, ou executores, ou apenas vínculo institucional).

Dos modestos custos do projeto citados no projeto, infere-se que a maior parte da verba foi destinada para a capacitação e supervisão inicial do programa (o restante seria destinado à publicações sobre o programa e seus resultados) evidenciando, mais uma vez, que esta tem sido uma constante nas iniciativas relacionadas às justiças alternativas: financiamentos para a capacitação e pouco ou nenhum recurso para a manutenção do projeto; fato que desestabiliza as iniciativas e colabora para seu não prosseguimento. 


\section{A situação de São José dos Campos:}

A partir de entrevistas realizadas em São José dos Campos, com atores ligados à agenda da justiça restaurativa no local, obtive a informação de que em 2009 a ONG CECIP e o Mediativa (ambos realizam capacitações de mediadores, conciliadores e facilitadores de justiça restaurativa) apresentaram a proposta de um programa de justiça restaurativa para o secretário da Secretaria de Educação do Município. A iniciativa teria partido do juiz da Vara da Infância e Juventude do local, juntamente com o secretário e o foco da iniciativa eram também as escolas.

Segundo o relato dos entrevistados, cerca de 10 escolas estavam sendo capacitadas por ano (em três anos de projeto, 2010, 2011, 2012 resultaram, portanto, cerca de 30 escolas capacitadas). Torna-se importante ressaltar que foram escolas municipais de ensino fundamental e os interlocutores afirmam que depois da capacitação as escolas são assessoradas mensalmente.

O projeto chega à cidade em 2009 e em 2010 começam as capacitações. Os entrevistados disseram assistir na época a palestras dos juízes de São Caetano do Sul e de São Paulo - este último participou também da iniciativa em Heliópolis. Ainda sobre as capacitações, teria havido uma divergência entre CECIP e Mediativa de modo que ambos dividiram seus lugares de atuação.

Também obtive a informação de que o objetivo principal, mais uma vez, é evitar que os problemas das escolas cheguem até o Judiciário. Mas não é somente nas escolas que iniciativas de justiça restaurativa estão surgindo. Existe uma fundação neste município que realiza um trabalho social com crianças e jovens em situação de vulnerabilidade social que também está participando do projeto de implantação de justiça restaurativa. Além de entrevistar a secretária de Secretaria da Educação do município, também visitei a fundação e conversei com três funcionárias que estão envolvidas com a questão do modelo alternativo de justiça no local.

Um dia antes de minha visita ao Fundhas ${ }^{65}$ em São José dos Campos, foi formalizado ali um grupo de justiça restaurativa formado pelas três entrevistadas frente à instituição. $\mathrm{O}$ grupo foi oficializado numa cerimônia que contou com a participação de um juiz da capital. Os planos, de acordo com as entrevistadas, incluíam uma proposta de formação (grupo de

\footnotetext{
${ }^{65}$ Fundação Hélio Augusto de Souza é uma instituição que, em parceria com a prefeitura do município de São José dos Campos, realiza uma série de trabalhos sociais voltados para a criança e o adolescente em situação de vulnerabilidade social.
} 
estudo) e de intervenção (práticas restaurativas, isto é, incluem aquelas práticas diversas vistas anteriormente: conversa restaurativa, círculo restaurativo, atendimento restaurativo, etc).

Cabe pontuar também que estas profissionais inserem adolescentes e seus familiares nas formações e capacitações que promovem. Ou seja, essas entrevistadas do Fundhas foram capacitadas e agora começam também a capacitar. Parece existir um interesse sempre muito grande em capacitar. Talvez isto aconteça porque acreditam na transformação social possibilitada pelo modelo alternativo, ou porque querem mobilizar capitais sociais, ou ainda os dois motivos conjuntamente visto que um não exclui o outro.

Importante destacar também que as entrevistadas disseram querer aplicar a justiça restaurativa aos adolescentes quando eles retornam para a instituição, depois de cumprirem pena na Fundação Casa. Esta afirmação nos leva a pensar mais uma vez em qual seria a função do procedimento restaurativo aqui, visto que este adolescente já teria passado pelo processo criminal e cumprido sua pena. Se introduzido o modelo nesta etapa do processo pelo qual o jovem infrator passa, são grandes as chances de a justiça restaurativa servir com fins de uma segunda punição. Se ela, por outro lado, for pensada no sentido de ajudar este jovem a se reintegrar novamente ao seu meio social depois do período de internação, podemos argumentar que neste caso embora a ideia seja positiva, não se trata de justiça restaurativa da forma como originalmente o modelo foi concebido.

\section{A situação de Heliópolis:}

Tive a oportunidade de entrevistar uma conselheira tutelar que atuava na região de Heliópolis, capital, na época em que o projeto de justiça restaurativa foi instalado ali. Esta entrevistada, que tem formação em pedagogia, participou ativamente do programa de justiça restaurativa naquele local, em um projeto que foi idealizado e coordenado por um juiz da Vara da Infância e Juventude de São Paulo.

Este projeto contou com a participação do CECIP (Centro de Criação de Imagem Popular) do Rio de Janeiro em parceria com a APS International Algemeen Pedagogish Studiecentrum da Holanda (ambas ONGs), além do viés possibilitado pela Comunicação Não Violenta.

Durante nossa conversa a entrevistada relatou que ela e outra colega tinham duas salas para justiça restaurativa, uma para sua realização na escola local e outra na comunidade 
(Conselho Tutelar). Os participantes foram capacitados pelo CECIP e pelo representante da $\mathrm{CNV}$, Dominic Barter, com quem tive a oportunidade de conversar também.

Pude verificar, através das entrevistas com os três personagens importantes do contexto do programa em Heliópolis: o juiz, a então na época conselheira tutelar e o representante da $\mathrm{CNV}$, que a iniciativa neste local se enfraqueceu devido ao deslocamento do juiz e da conselheira que eram figuras chave do projeto no local.

Em meu mestrado realizei um trabalho ${ }^{66}$ que analisou, através da ideia de importação e exportação de expertise jurídica e relações com a política local, como pautas internacionais como a justiça restaurativa têm dificuldades de se manter se seus patronos se deslocam em suas carreiras, o que geralmente acaba acontecendo. Este deslocamento de seus principais idealizadores enfraquece a pauta no local que não conta com mais incentivadores e o que resta então é o que (1990) chama de transcrito oculto, isto é, uma rejeição que não se revela através de ambates, enfrentamentos, oposições, lutas abertas. Ao invés disso os agentes optam pela inércia, relatam as dificuldades, culpam a falta de interessados, entre outras justificativas.

Foi essa a situação encontrada no contexto de Heliópolis. Como a entrevistada afirmou, bastava ela sair da comunidade que desmontavam sua sala do programa de justiça restaurativa. Depois que ela assumiu novo cargo no Conselho dos Direitos da Criança e do Adolescente, em São Paulo, e depois que o juiz também foi transferido, o programa definitivamente se extinguiu. Não obstante, a entrevistada relatou que ela e o juiz, bem como a ONG CECIP, têm conversado a respeito das possibilidades de reimplantar o programa neste local, mas até o final da redação desta tese nada foi definido sobre a questão.

Também é interessante notar que foi justamente sobre a continuidade do programa em Heliópolis que questionei à representante do CECIP, durante uma entrevista. O fato de eu ter afirmado que o programa naquele local não funcionava mais deixou a entrevistada bastante incomodada e foi quando ela argumentou que a justiça restaurativa não se mede dessa forma, que não era possível, portanto, falar na extinção de um programa visto que o paradigma da justiça restaurativa já tinha sido implantado no local (a justiça restaurativa como um valor seria capaz de mudar a mentalidade e o comportamento dos envolvidos com a proposta).

Mesmo que o programa não tenha continuado em Heliópolis, o acesso à documentos relacionados ao projeto que viabilizou sua instalação permite entrever mais detalhes de como funcionava.

\footnotetext{
${ }^{66} \mathrm{O}$ título do trabalho é Internacionalização do saber jurídico e redes profissionais locais: um estudo sobre justiça restaurativa em São Carlos-SP e São Caetano do Sul-SP. Dissertação de mestrado apresentada ao Programa de Pós-Graduação em São Carlos, SP, 2010.
} 
O campo de aplicação ali não se restringiu aos atos infracionais, mas, de acordo com o projeto, englobou também transgressões disciplinares nas escolas. De acordo com este documento consultado, previa-se que todos os acordos celebrados em ambiente escolar fossem encaminhados ao Ministério Público, que sobre os mesmos emitiriam um parecer, opinando, em caso de concordância, por sua homologação e concessão de remissão ao adolescente pelo ato praticado:

\begin{abstract}
"Os acordos, sendo homologados pelo juízo, serão acompanhados pela equipe técnica ou Conselho Tutelar quanto ao seu efetivo cumprimento. Em caso de não cumprimento, considerando a mudança de paradigma que o presente projeto pode representar aos envolvidos, os participantes serão chamados a juízo para diálogo com a equipe técnica do juízo, recebendo orientação e novo estímulo à compreensão do processo ao qual se submeteram e da importância do compromisso por eles assumidos, depois de investigadas e ouvidas as causas que levaram ao desrespeito daquilo a que se comprometeram". (Projeto Heliópolis e Guarulhos: p.28)
\end{abstract}

Este trecho é muito interessante porque nele é possível visualizar uma contradição na proposta. Afirma-se que em caso de não cumprimento do que foi acordado pelo procedimento restaurativo os envolvidos serão chamados em juízo para saberem da importância que a justiça restaurativa representa e assim se comprometerem com a proposta. Assim, embora o acompanhamento seja importante, no sentido de serem verificadas se as partes cumpriram o que ficou acordado e se se sentiram satisfeitas, fica claro como embora a justiça restaurativa represente uma mudança de paradigma, na opinião de seus defensores, para que os envolvidos tomem consciência disso precisam que representantes do modelo de justiça oficial lhe digam.

Mais uma vez a expertise da justiça restaurativa não é mobilizada para angariar apoio, através de seus próprios "méritos". A população não é impelida a se apropriar do modelo alternativo e procurá-lo espontaneamente, é preciso que ela esteja sempre acoplada ao sistema de justiça criminal.

Ainda segundo o projeto, o não cumprimento do acordo por desejo consciente do agressor implicará retomada do processo de conhecimento, aos moldes do que acontece em uma interpretação da lei 9.099/95, no Juizado Especial Criminal, autorizando a análise do oferecimento de remissão com medida ou o oferecimento de representação, se for o caso. (idem, p. 30).

Quando se refere à metodologias de avaliação o texto é bastante vago, o que só vem a reforçar a questão já mancionada da falta de avaliações dos programas: 
"Trata-se de um projeto piloto. Entende-se que a avaliação deve ser realizada quanto à efetiva prestação dos serviços convencionados, execução das ações previstas, assimilação dos ensinamentos prestados pelos capacitadores (equipe técnica, educadores e integrantes da comunidade ou agentes públicos na ativa), e pelo relativo envolvimento da comunidade. A avaliação deverá se voltar precipuamente para as dificuldades e potencialidades de desenvolvimento do projeto, procurando-se estabelecer os parâmetors pelos quais, à vista da realidade concreta de uma megalópole (capital do Estado de São Paulo, com seu complexo sistema de justiça na área da Infância e Juventude), e da segunda maior cidade do Estado de São Paulo (Guarulhos), poderá ter curso um maior envolvimento comunitário nas questões de segurança e justiça. Como a capacitação tomará certa parte do ano, parece-nos difícil que a avaliação quanto à efetiva mudança de comportamento dos envolvidos, com redução dos índices de reincidência, embora se possa avaliar o grau de satisfação na participação nos círculos através de questionários". Grifos mantidos do original (ibidem, p. 38)

Dos relatos acerca das situações nas três localidades, mais uma vez ficam evidentes as dificuldades na manutenção de programas vinculados ao modelo alternativo da justiça restaurativa. Embora haja um investimento inicial para a mobilização e capacitação dos profissionais para trabalharem com a justiça restaurativa, a partir dos grupos que promovem as capacitações, os projetos ou programas não conseguem se manter após estes investimentos iniciais.

Alguns dos motivos vistos são: o fato de os programas de basearem no voluntarismo dos profissionais, ou seja, a falta de uma remuneração desestimula grande parte dos envolvidos, e também não existe estrutura para estes facilitadores. Em São Cateano do Sul uma das facilitadoras admite que tinha passado a receber um lanchinho, mas que antes nem disso dispunha.

Outro motivo se reporta ao deslocamento dos profissionais, o que deixa as iniciativas muito vulneráveis sem seus principais incentivadores. Como vimos anteriomente, a pauta da justiça restaurativa ainda é uma agenda marginal no mundo do Direito, tendo os profissioanis que constantemente reforçarem a validade dessa expertise entre seus pares. Desse modo, sem estes profissionais para estimularem continuamente a pauta ela acaba sendo adiada e se dilui nas franjas do sistema.

Como relatado também pelo diretor da escola em Campinas, a justiça restaurativa parece não se encaixar nas necessidades cotidianas da escola. Todo o procedimento do círculo 
demanda um tempo e uma organização que a escola não possui em seu dia-a-dia para resolver os conflitos com que se depara. 
CAPÍTULO 4:

DUAS HISTÓRIAS SOBRE A JUSTIÇA RESTAURATIVA 
Após termos visto no primeiro capítulo da tese a dimensão conceitual relacionada à justiça restaurativa; no segundo capítulo as questões profissionais atreladas a este modelo e no terceiro como são suas práticas, através da análise do programa de São Caetano do Sul, neste capítulo serão apresentadas duas narrativas acerca da justiça restaurativa. Mais especificamente, são histórias que contam o envolvimento de dois atores com este modelo de justiça no Brasil.

Estas narrativas contam duas histórias bastante diferentes a partir de dois profissionais que ocupam (ou ocupavam, como o caso de um deles) posições diferentes neste campo em torno deste modelo alternativo de gestão de conflitos em nosso país.

A ideia para este capítulo foi a de contrastar o relato de um defensor público e exassessor da Secretária de Reforma do Judiciário, obtido durante minha pesquisa de mestrado (TONCHE, 2010), com o relato de uma assistente social que participa do programa de São Cateano do Sul, obtido durante a pesquisa de doutorado.

O primeiro exemplifica o caso de um agente que ocupou uma posição central em torno da questão da justiça restaurativa, participando das discussões que viabilizaram a implantação dos três projetos pilotos brasileiros em 2005. O segundo relato, de forma diferente, ilustra o caso de uma agente que ocupa uma posição periférica no contexto, atuando no programa em São Caetano do Sul como assistente social naquele local, atendendo adolescentes e seus familiares no programa de justiça retaurativa que funciona na cidade.

Destes dois depoimentos, obtidos em entrevistas, podemos inferir que os dois personagens envolvidos com o conteúdo restaurativo apresentam perspectivas muito diferentes a respeito da questão. Primeiro, podemos inferir que isto acontece por tratarem-se de profissionais de áres distintas, ocupando seus cargos em lugares diversos também. Mas, mais do que isso, estes dois relatos nos mostram também como a justiça restaurativa foi desenhada inicialmente pelos profissionais que estavam na Secretraria para ser uma iniciativa de sucesso; algo que constrasta fortemente com o discurso da assistente social que, ocupando uma posição periférica, atuando no programa de justiça restaurativa de São Caetano do Sul em suas bases, ressalta as dificuldades encontradas para a manutenção desta agenda da justiça restaurativa, como exercido cotidianamente em seu trabalho. Esta entrevistada vai contando uma história de sucessivas decepções com o programa do qual participa, de modo que ficam claras para o leitor as dificuldades que se apresentam para aqueles que se envolvem com a pauta em suas capilaridades.

O objetivo deste capítulo é tentar mostrar os caminhos que a justiça restaurativa percorreu em nosso país, tendo recebido inicialmente o apoio do Ministério da Justiça, pela 
Secretaria de Reforma do Judiciário, que apostava em seu sucesso, para depois compor um quadro no qual seus programas funcionam com muitas dificuldades: iniciativas pensadas para funcionarem a custo praticamente zero, baseadas sobre o trabalho voluntário de mediadores e contando com a participação de pessoas que em sua grande maioria não procuraram espontaneamente pelo programa, tendo sido antes impelidas pelos juízes ou promotores que atendem os casos, sem contar a pressão que seus envolvidos recebem por produtividade e divulgação de bons índices.

Hoje, a justiça restaurativa não está mais na pauta da Secretaria de Reforma do Judiciário, como foi possível constatar em um evento a respeito do Judiciário Brasileiro que aconteceu na Universidade de Campinas (UNICAMP), no dia 07 de abril de 2015. Em sua apresentação, o assessor da Secretaria, representando o atual secretário, que não pôde comparecer, falou sobre as iniciativas que a secretaria tem apoiado, com vistas à reforma e modernização dos canais de acesso e funcionamento do sistema de justiça brasileiro. Dentre as iniciativas apoiadas foram citadas a conciliação, a mediação pré-procesual e a justiça comunitária, entre outros exemplos. Quando questionado especificamente a respeito da justiça restaurativa, uma vez que a própria Secretaria viabilizou com apoio institucional e financeiro os três projetos piloto do modelo há dez anos, o assessor respondeu que "a conciliação e mediação tudo bem, mas a justiça restaurativa já é criminal né, é diferente...” e admitiu em seguida que atualmente a instituição não tem nenhum projeto ligado à justiça restaurativa.

Sinhoretto $(2011 ; 2014)$ encontrou um quadro parecido ao da justiça restaurativa mostrado aqui quando pesquisou a história por trás da inauguração dos Centros de Integração e Cidadania na cidade de São Paulo. Em sua tese de doutorado, que posteriormente foi publicada (2011), a autora relata como os CICs foram pensados e criados para serem o início de uma grande reforma para democratizar as instituições da justiça. Idealizado inicialmente para melhorar a oferta dos serviços de justiça em pontos mais afastados dos grandes centros urbanos (uma reforma pelas franjas do sistema), aos poucos o foco desta iniciativa e seu perfil foram se alterando.

De acordo com a autora, o projeto de criação dos CICs, que foi redigido na década de 1990 por um grupo de notáveis penalistas, propunha a criação de cerca de 20 centros, onde seriam atendidos casos criminais, a partir da articulação dos serviços das polícias Civil e Militar, Ministério Público, Judiciário e assistência judiciária. Os serviços, localizados em um mesmo edifício, operariam de forma integrada, o que geraria celeridade para vítimas e réus de crimes e o aumento do controle mútuo dos agentes estatais. 
$\mathrm{O}$ fato de as iniciativas se localizarem em bairros mais afastados, iria favorecer a proximidade e a identificação entre os cidadãos e os agentes estatais, o que também deveria aumentar o controle popular sobre as instituições e reduzir as distâncias simbólicas entre os "operadores da justiça" e o "homem comum: "Tratava-se de uma proposta ousada para o momento, apoiada numa profunda reforma das condições do acesso à justiça, vista como condição da democracia para seus formuladores" (2014, p.50).

Mas, diferentemente das ideias e propostas iniciais, é possível acompanhar ao longo da análise da autora que:

O CIC, ao invés de ser um polo propagador de inovações, da periferia em direção ao centro, das bases em direção ao topo - como na aposta dos seus criadores -, foi rapidamente colonizado pelas culturas organizacionais das instituições parceiras, tornando-se um posto de trabalho desprestigiado na construção das carreiras profissionais dos seus ocupantes $(2014$, p. 51).

Dessa forma, através da realização de uma etnografia, a pesquisadora acompanhou todo o processo de criação e implantação dos CICs chegando, ao fim da pesquisa, a conclusões que aproximam novamente dois objetos de estudo que têm muito em comum:

Apropriações e disputas diversas foram distanciando o programa governamental de seus objetivos, ilustrando as dificuldades de implementar uma reforma institucional suportada por agentes externos. Entretanto, como encontra eco em estratégias profissionais que propugnam a democratização interna das instituições e do acesso à justiça, o programa perde seu caráter inicial, mas não se extingue. (2006, p. 376)

Situação semelhante acontece com o caso da justiça restaurativa: mesmo com as dificuldades na manutenção de alguns de seus programas, eles não se extinguem, como é o caso do programa em São Caetano do Sul; pelo contrário, o discurso sustentado pelos seus envolvidos é sempre de muito sucesso, embora possa-se facilmente questionar esse argumento e cada vez mais cidades têm demonstrado interesse pelo tema. 


\title{
4.1 UMA HISTÓRIA DE SUCESSO
}

Sobre a história da vinda da pauta da justiça restaurativa para o Brasil, foi possível observar, a partir das entrevistas realizadas com profissionais envolvidos na questão, que cada um conta uma versão diferente, ressaltando sempre mais seu próprio envolvimento com o modelo, que pode ser compreendido como um objeto de disputa neste campo atavessado pelos mais diferentes personagens. Um ex-procurador da justiça, que já foi presidente do Instituto do Direito Comparado (IBDC) afirma:

\begin{abstract}
Existem muitas dúvidas e controvérsias sobre como a "justiça restaurativa chegou ao país". ...(nome) reivindica esse pioneirismo com a experiência de Jundiaí. ...(nome) também é visto como pioneiro com o seu projeto de Porto Alegre. Contudo, essa briga pela paternidade é irrelevante, não passando de uma disputa em torno da paternidade de uma criança cujo rosto é inclusive tapado pela nãopublicação e disponibilização, ao público, à comunidade acadêmica e ao movimento restaurativo, dos relatórios de avaliação desses projetos, feitos pelo ILANUD, PNUD e Universidade de Brasília (exprocurador de justiça aposentado)
\end{abstract}

Como vimos anteriormente, o ano de 2005 marca o início das atividades ligadas à justiça restaurativa no Brasil. Neste ano, foram inaugurados três programas pilotos de justiça restaurativa com o apoio da Secretaria da Reforma do Judiciário e PNUD. Estes programas iniciaram-se em São Caetando do Sul (SP), Núcleo Bandeirante, Brasília (DF) e Porto Alegre (RS).

A inauguração destes programas aconteceu durante a gestão de Sérgio Renault na Secretaria da Reforma do Judiciário (2003-2005), advogado que ocupou a posição de secretário durante a gestão de Márcio Thomaz Bastos como ministro da justiça (2003-2007). Foi também naquele contexto de grande debate em torno da Reforma do Judiciário, uma marca das gestões de Thomaz Bastos e do ex-presidente Lula, que foi criada a própria Secretaria de Reforma do Judiciário.

É importante ressaltar que a vinda destes profissionais para atuarem na nova secretaria acontece num momento de mudanças políticas decisivas, com a nomeação de Thomaz Bastos como ministro da Justiça pelo então presidente Luís Inácio Lula da Silva (2003-2006; 20062010). O novo ministro, ao trazer consigo profissionais com posições intelectuais ou políticas consoantes à sua, ajudou a impulsionar uma visão mais heterodoxa da profissão, o que vai também ao encontro da proposta do governo petista de maior acesso da população à justiça. 
Durante a realização de minha pesquisa de mestrado (TONCHE, 2010) entrevistei um defensor público que foi assessor da Secretaria de Reforma do Judiciário na época em que a instituição foi responsável pelo apoio aos três projetos pilotos, juntamente com o PNUD (Programa das Nações Unidas para o Desenvolvimento). A respeito da questão o mesmo relata:

\begin{abstract}
“(...) enfim, se criou a Secretaria de Reforma do Judiciário. O titular era o Sérgio Renault, o advogado de São Paulo com quem eu tive a satisfação de trabalhar por dois anos praticamente, ele tinha como assessores um economista, chefe de gabinete, o (nome) que acabou virando secretário logo depois e eu da área jurídica, além de, enfim, alguns assistentes, poucas pessoas. A estrutura da Secretaria era bem enxuta e o interessante é que nós tínhamos bastante campo e de uma certa forma, autonomia pra focarmos, trazermos iniciativas novas. A sensação naquele momento de início da reforma do Judiciário era que nós tínhamos que pensar o problema estrutural do Poder Judiciário, do sistema de justiça em geral. Pra isso tínhamos que

mexer na Constituição, tinha a emenda lá da Reforma do Judiciário que acabou sendo aprovada. Havia uma demanda por uma formulação de leis mais modernas no tocante à questão processual, mas além, enfim, dessa profissionalização do Judiciário, dessa necessidade de celeridade, havia também essa preocupação, acho que pela primeira vez entra na agenda política brasileira a questão do acesso à justiça, com tanta força e dentro dessa questão do acesso à justiça a gente tem a questão do fortalecimento das Defensorias Públicas e também a preocupação sobre a questão dos meios alternativos de resolução de conflitos, entre outras coisas, acesso coletivo, juizado especial, mas, o foco também na questão dos sistemas alternativos de resolução de conflitos."
\end{abstract}

O então assessor da Secretaria da Reforma do Judiciário relatou que tomou conhecimento da justiça restaurativa quando o próprio secretário perguntou se ele poderia comparecer a um evento sobre o tema que aconteceu em Brasília: " você poderia cuidar disso" teria dito o secretário.

Foi nessa ocasião que o entrevistado tomou contato com a justiça restaurativa, ou seja, como assessor da referida secretaria foi chamado a participar deste evento sobre o tema, e é ocupando essa posição no Executivo que ele pôde colaborar na captação da verba para o financiamento dos programas piloto.

Aceito o convite pela secretaria, o entrevistado começou a pesquisar o assunto para se preparar para aquele evento, que teria ocorrido no final de 2003 (não há certeza quanto à data). Até então, afirma nunca ter ouvido falar no modelo da justiça restaurativa. 
Este evento em Brasília contou com a participação da Associação dos Juízes do Distrito Federal, Instituto Brasileiro do Direito Comparado e forma recebidos representantes da Nova Zelândia, envolvidos com o conteúdo da justiça restaurativa, além de especialistas argentinos.

A partir do evento em Brasília foi surgindo um envolvimento progressivo da Secretaria com tema através do estreitamento de laços com pessoas já atuantes aqui no Brasil e com o programa na Nova Zelândia. Estudiosos desse país vieram dissertar sobre o tema da mesma forma como também foi formada uma delegação, um grupo de juízes, promotores e o assessor entrevistado, como representante do Executivo, que foi até esse país conhecer pessoalmente o funcionamento do programa. Nessa excursão tiveram a oportunidade de visitar vários estados e ver como se dá a operacionalização dos programas neozelandeses. Foi depois dessa visita ao país que surgiu o projeto da Secretaria: "Implementando práticas restaurativas no sistema de justiça brasileiro".

Nesse ínterim já havia uma parceria da secretaria com o PNUD para fomentar programas alternativos de justiça, de maneira que depois da viagem o assessor sugeriu que fosse incluída neste projeto em comum uma linha para tratar especificamente da questão da justiça restaurativa. E a verba foi aprovada, o que possibilitou pensar melhor a respeito dos projetos piloto.

Como relatado na entrevista, eram duas preocupações da instituição (Secretaria) naquele momento: criar e estabelecer mais meios de pacificação social e tentar diminuir o número de processos. Fica claro que os dois objetivos estão intimamente ligados já que, como o mesmo afirma, o fato de poder proporcionar a diminuição do número de processos dá mais força política pra esse tipo de proposta de meios alternativos de administração de conflitos. Ela atende também a um dos principais requisitos hoje quando se discute a Reforma do Judiciário, que são meios de diminuir a morosidade do sistema de justiça brasileiro.

Segue um excerto da entrevista com o assessor em que ficam bem ilustrados os termos em que a justiça restaurativa veio a se instalar no Brasil:

"Me pareceu prudente que nós firmássemos parcerias sólidas com juízes e promotores interessados na aplicação daquilo por dentro do sistema de justiça pra garantir efetividade prática, compromisso dos operadores senão ser apenas, apenas não, mas não ser um programa puramente ligado à comunidade até porque no âmbito do direito criminal onde tudo é institucionalizado, você tem poucos desvios do sistema formal no âmbito criminal. Então me pareceu que pra perseguir os fins que eu acreditava que seriam interessantes, que é demonstrar alternativas de reação do Estado ao fenômeno criminal, nós tínhamos que ter parceria com os juízes criminais ou juízes que 
atuavam na área de ato infracional cometido por adolescentes e a partir daí que surge o programa 'Promovendo práticas restaurativas no sistema de justiça brasileiro' que eu propus e o PNUD encampou nós desenvolvemos, conseguimos a linha de crédito e nós pensávamos em atuar na produção de conhecimento científico (Defensor público entrevistado, ex-assessor da Secretaria de Reforma do Judiciário)

Neste excerto da entrevista, fica claro como a justiça restaurativa chega ao país através de uma via altamente institucionalizada, promovida por profissionais que ocupam posições estratégicas em seus campos de atuação, algo que contrasta com as bases filosóficas da justiça restaurativa que destacam suas origens na recuperação de meios de gestão de conflitos de populações tradicionais, reforçando o empoderamento das partes em conflito sobre os meios de reparação do problema.

O entrevistado prossegue:

"Então essa chancela e esse apoio institucional do Ministério da Justiça acaba abrindo portas, muitas vezes os tribunais falam 'o que é esse juiz aí, esse juizinho de primeira instância está pensando demais, querendo revolucionar demais' e aí quando você tem uma iniciativa do MJ, o Ministério da Justiça apoiando, esses juízes também talvez, consigam romper obstáculos e barreiras naturais dentro daquelas estruturas conservadoras, arcaicas que são os tribunais de justiça". (idem)

Nesse sentido, é oportuno destacar que a justiça restaurativa no Brasil parece que segue a mesma lógica do argumento que floresceu no país a respeito da discussão do Estado Democrático de Direito, a de que as principais reformas constitucionais não foram impelidas pela população sobre a qual atua senão pelo próprio Estado. Assim, muitas transformações sociais figuram nos papéis sem que efetivamente exista uma cultura de prática desse direito, de forma que, muitas vezes, ao se idealizar uma mudança na estrutura social brasileira, pensase primeiro em validá-la constitucionalmente porque isso levaria a uma mudança efetiva no corpo da população posteriormente.

Este pensamento está tão arraigado que grande parte dos entrevistados a respeito da justiça restaurativa afirma acreditar que a sua ascensão depende muito da sua legalização formal. "Você ainda tem um caminho por percorrer o que não vai ser feito só por uma postura isolada, isso tem que ser assumido institucionalmente, legalmente também, isso precisa entrar na lei pra que as pessoas comecem a mudar” (Juiz de São Caetano do Sul). 
Muitos entrevistados afirmaram que a "solução" para a justiça restaurativa seria ela se transformar em uma política pública. Isso talvez resolvesse o problema da falta ou descontinuidade dos financiamentos que prejudicam a permanência dos programas, mas cabe questionar se seria o suficiente no sentido de estabelecer o modelo enquanto uma via legítima de administração de conflitos, reconhecida pelos pares profissionais e pela população que é atendida pelos programas.

No Brasil, portanto, a pauta internacional da justiça restaurativa veio "de fora" e se dissemina a partir "de cima". Existe uma preocupação aparente -ao menos no plano das idéias- em conscientizar cada vez mais a população sobre os benefícios da justiça restaurativa e tentar fazer com que a comunidade se aproprie cada vez mais deste método de administração de conflitos, reservando espaços próprios para a realização dos círculos. Mas, o que se verifica efetivamente são iniciativas altamente personalizadas, lideradas por juízes e, ainda dependentes do prosseguimento da atuação destes profissionais, como pudemos observar ao longo da tese.

Efetivamente, o ponta-pé inicial para o desenvolvimento da proposta de justiça restaurativa no país foi a junção desses personagens de orientações políticas e ideológicas consonantes que possibilitaram não só a criação da Secretaria de Reforma do Judiciário, como posteriormente a fomentação do modelo que a própria Secretaria fez ao reunir esses estudiosos com autoridades do programa desenvolvido na Nova Zelândia. Isso permitiu estabelecer os três projetos pilotos com o aval institucional e financeiro da Secretaria e do PNUD.

O auxílio financeiro inicial foi pensado para três projetos pilotos e foram escolhidos três projetos: o do Núcleo Bandeirante (Distrito Federal) atuando no Juizado Especial Criminal; em São Caetano do Sul, São Paulo, com foco na área da infância e juventude e integração com o sistema público educacional e Rio Grande do Sul (Porto Alegre) onde vem sendo aplicado na Vara de Execuções de Medidas Sócio-Educativas na área de infância e juventude.

O projeto da Secretaria de Reforma do Judiciário caminhava então buscando dois pontos de apoio: o programa em si, a "prática" e também a teoria, com planos de publicações e realização de eventos como o que ocorreu em Brasília, em 2004, intitulado "Acesso à justiça por sistemas alternativos de resolução de conflitos".

Dentro da Secretaria de Reforma do Judiciário, o assessor entrevistado se tornou o coordenador do programa que viabilizou a estréia dos três projetos pilotos, mas depois sua atuação sobre a questão ficou limitada devido as suas novas atribuições. 
Quando o próximo secretário assumiu a Secretaria -ele chegou a convidar o assessor para ser seu diretor na gestão- ele volta para a Procuradoria Geral do Estado (PGE). Por questões políticas, como o mesmo entrevistado pontua, não foi permitida uma renovação do seu afastamento e ele sai então da Secretaria. Seus esforços se voltam nesse momento para a criação da Defensoria Pública. O ex-assessor trabalha desde então na administração central da Defensoria Pública, além disso, também coordena a Comissão de Segurança Pública e de Justiça do IBCCrim. Uma promotora entrevistada, em tom de brincadeira, fala que ele "abandonou a questão" da justiça restaurativa, o que é interessante dado o grau de envolvimento que este agente tinha com a questão da justiça restaurativa:

\begin{abstract}
"Bom nesse momento eu tenho maior contato e aí enfim, surge de fato, não que esses programas não existissem, é importante frisar isso, em todos esses locais já havia todas as condições, eu não sou, o pessoal brinca "o (nome) é o pai" isso eu falo "gente eu não sou o pai de nada" tava na hora certa no local certo, foi um modelo que eu entendi, extremamente interessante e viável, por colocar em xeque um problema cultural que eu acho que está na base dos nossos problemas de violência e segurança pública e eu tinha e estava ocupando um cargo executivo na época eu tinha contato com os oficiais do PNUD então eu viabilizei esses recursos, mas evidentemente que essas condições já existiam" (defensor público e ex-assessor entrevistado)
\end{abstract}

Outra defensora entrevistada vinculada ao programa chegou a dizer, em tom de brincadeira, que ele teria os abandonado. Nesse sentido, é importante destacar que entre os profissionais observados pela pesquisa, aqueles que compõem a rede que apóia a justiça restaurativa e que foram para o Executivo não se desvincularam da profissão e da carreira evidenciando, dessa maneira, a força do profissionalismo nesse campo.

Mais do que isso, podemos dizer que esse movimento faz parte das carreiras e permite entrever que não é a justiça restaurativa que alcança novas dimensões, mas sim aqueles que estão na rede que a encadeia.

A trajetória profissional desse defensor público do estado de São Paulo e ex-assessor da Secretaria de Reforma do Judiciário entrevistado, pode ser ilustrativa e exemplifica o argumento defendido por Engelmann (2006), a respeito do ativismo judicial em nosso país: No caso brasileiro, os advogados relacionados à militância política através do direito constituem uma modalidade de agentes que conseguiram ascender ao espaço jurídico 
combinando a expertise jurídica com um conjunto de relações estabelecidas pelo militantismo (2006, p.132).

Este entrevistado inicialmente trabalhou na Procuradoria Geral do Estado (PGE), em São Paulo, na PAJ, que é a Procuradoria de Assistência do Judiciário, fazendo o que os profissionais da área chamam de "clínica geral", ou seja, prestando os mais diversos tipos de atendimento ao público.

Antes da criação da Defensoria Pública, o serviço que se destinava à população que não podia arcar com os custos de um processo judicial e tampouco com a constituição de um advogado, era prestado pela Procuradoria de Assistência Jurídica - PAJ, órgão vinculado à Procuradoria Geral do Estado (PGE). Esta instituição era, ao mesmo tempo, encarregada de prestar a consultoria e a defesa jurídica ao próprio Estado, fato que dissuadia o movimento de ações contra ele. Além disso, a PGE não tinham autonomia administrativa e orçamentária, o que foi conquistado pelas Defensorias Públicas com a Reforma Constitucional de 2004 (PEC da Reforma do Judiciário).

Nela prestavam-se, então, diversos serviços ("clínica geral" é o termo utilizado entre estes operadores do Direito) e nesse espaço o entrevistado começa a se envolver com a política institucional da Procuradoria, a partir de um grupo de trabalho de Direitos Humanos que era na época coordenado por uma conhecida procuradora. Nesse momento, o entrevistado se insere no grupo e começa a ter uma participação mais ativa na carreira, tomando parte na discussão a respeito da criação da Defensoria Pública do estado de São Paulo, que era uma matéria amplamente discutida na época.

Nesse grupo questionava-se muito a inexistência de uma Defensoria Pública de São Paulo e também do sindicato dos procuradores do estado de São Paulo, hoje o Sindiproesp. Este sindicato foi assumido por um colega do entrevistado, que hoje é defensor, assim como ele, e ambos trabalham na administração da Defensoria. Esse grupo de colegas fomentava, então, uma discussão sobre o modelo de assistência jurídica de São Paulo e a criação da Defensoria.

Isso de uma forma ou de outra acabou levando o entrevistado, segundo seu depoimento, para o Ministério da Justiça tão logo o presidente Lula assumiu seu mandato e nomeou como ministro da Justiça o advogado criminalista Márcio Thomaz Bastos.

De acordo com seu relato, eles receberam um contato do chefe de gabinete do ministro pedindo a indicação de alguns, já do movimento para a criação da Defensoria Pública de São Paulo, para trabalhar na Reforma do Judiciário com foco na questão do acesso à justiça. A diretoria do sindicato se reuniu e indicou o entrevistado para conversar com o chefe de 
gabinete que, de fato, formalizou o convite e ele foi afastado da Procuradoria, cedido pelo estado de São Paulo, pelo Governo Federal, para fazer esse trabalho de assessoria na Secretaria de Reforma do Judiciário, que tinha acabado de ser criada em meio às discussões da "caixa preta" 67.

O caminho percorrido pelo entrevistado corrobora o argumento de Engelmann, de que profissionais do Direito ligados à militância política, através de sua atuação profissional, conseguem alcançar novas posições em suas carreiras combinando saber especializado com relações estabelecidas pelo militantismo. Assim, como podemos observar do relato do defensor entrevistado, seu envolvimento com o movimento pela criação da Defensoria Pública foi um fator decisivo para sua promoção na carreira.

A ampliação do espaço político nas carreiras jurídicas, algo que contraria a via de profissionalização tradicional no meio que ressalta a neutralidade do conhecimento especializado, muitas vezes é a via para o deslocamento e avanço na carreira de muitos profissionais, como foi o caso do entrevistado, como descrito acima. Além disso, essa neutralidade vem sendo confrontada por diversos grupos que apregoam uma prática da advocacia voltada para o compromisso social e uma intervenção menos hierarquizada da relação profissional-cliente, sendo a atuação da Defensoria exemplar nesse aspecto.

Em seu artigo chamado Internacionalização e ativismo judicial: as causas coletivas Engelmann ainda retoma autores europeus cujas pesquisas demonstrariam que:

"A especificidade do engajamento político pelo Direito envolve a análise das estratégias dos movimentos sociais na apropriação do espaço judicial, o papel dos juristas na tradução e formalização das "causas políticas" na linguagem das disputas no interior do Judiciário e a conciliação da atuação profissional com o militantismo político" (2006, p. 126).

Bonelli (2003) também nos lembra que é preciso entender a relação profissão- Estado como uma interação que ocorre entre esferas independentes, ou, mais ainda, como um processo histórico que se desenvolve numa via de mão-dupla. Com efeito, são pólos autônomos, mas que se interagem e, provocam, acima de tudo, processos dinâmicos internos às profissões e à política.

\footnotetext{
${ }^{67} \mathrm{O}$ ex-presidente Lula intensificou os debates em torno da reforma do judiciário ao declarar em matéria de jornal que: “(...) É por isso que nós defendemos há tanto tempo o controle externo do Poder Judiciário. Não é meter a mão na decisão do juiz. É pelo menos saber como funciona a caixa-preta de um Judiciário que muitas vezes se sente intocável" (Sombra do poder: Lula critica caixa-preta do Judiciário e defende controle. Folha de S. Paulo, 23 de abril de 2003, Caderno Brasil. Texto de Lilian Christofoletti).
} 
Almeida (2009), em estudo sobre a as elites jurídicas e a política de administração da justiça no país, construiu um esquema interpretativo para caracterizar atores e trajetórias profissionais envolvidos na discussão da Reforma do Judiciário tomando, por base, possíveis combinações entre capitais políticos e jurídicos presentes nas carreiras destes agentes.

$\mathrm{O}$ autor, que vem de uma tradição do pensamento sociológico centrado na figura de Bourdieu, construiu tipos ideais como recurso de análise e mostra como a associação de diferentes tipos de capitais viabilizou mais o prosseguimento de algumas pautas na discussão sobre a reforma, em detrimento de outras. Os atores investigados pelo presente estudo não somente se encaixam nos perfis de dois, dos quatro tipos criados pelo autor, como alguns são efetivamente citados na descrição. São as categorias “juristas da política” e os "juristaspolíticos" os dois tipos ideais a que me referi. Segue a descrição do tipo juristas da política:

(...) são os assessores jurídicos de gabinete e os advogados de partidos, que prestam serviços técnicos especializados à atividade de políticos profissionais e acumulam, dessa forma, quantidades consideráveis de capitais políticos nas redes de relacionamento com agentes do campo político, ao passo que mantêm sua vinculação estrita ao campo jurídico pelo exercício de funções típicas e especializadas (...) é nesse espaço de convergência de capitais jurídicos e políticos que se situam, também, a maior parte dos juristas localizados na Secretaria de Reforma do Judiciário do Ministério da Justiça, responsável pela liderança executiva do primeiro ciclo reformista, recrutados entre assessores jurídicos de gabinetes de políticos do PT e advogados particulares com histórico de representação técnica de interesses de políticos do PT. (ALMEIDA, 2009, p. 10)

Já sobre os juristas-políticos, eles seriam:

\begin{abstract}
“(...) agentes que tramitam entre os campos político e jurídico com relativo equilíbrio de investimentos, embora mantenham vinculação predominante ao mundo do Direito, seja na marca de sua atuação na política (como ministros ou secretários de justiça) ou mantendo pautas jurídicas em suas atividades parlamentares, seja no maior tempo de vida dedicado as atividades jurídicas". (idem)
\end{abstract}

Como exemplos do último tipo cita o ministro da justiça Márcio Thomaz Bastos e seu primeiro chefe de gabinete Sérgio Sérvulo da Cunha. Os tipos definidos acima correspondem a uma maneira de analisar trajetórias profissionais que se situam nas fronteiras entre profissão e política. O autor, a partir de conceitos de Bourdieu como o capital, investiga profissionais que circulam entre campos distintos, porém conectados, o que traz uma série de implicações 
para os profissionais dos campos do Direito e da política (e nas intersecções entre os dois campos), ainda mais em momentos de reformulações institucionais e ingresso de pautas internacionais de conteúdo mais crítico, como é o caso da justiça restaurativa ou mesmo a própria questão da Reforma do Judiciário.

Para Almeida, os debates em torno de propostas como as da Reforma do Judiciário podem ser entendidas tanto pela diversificação social das bases profissionais das carreiras jurídicas (em oposição a menor variação na composição do pólo dominante que ainda estaria bastante associado às estruturas tradicionais) quanto pela circulação de grupos de juristas entre posições de elite.

Nesse sentido, podemos inferir que a pauta da justiça restaurativa se beneficia dessa diversificação social nas bases das profissões jurídicas bem como da circulação de grupos de juristas ocupando posições de decisões, como citado pelo autor, para se instalar no país. Isto porque ela faz parte de uma vertente crítica no campo do Direito e foi viabilizada a partir da ascensão de um grupo de juristas de visão mais pluralista a cargos de decisão no Executivo.

Além disso, assim como Sinhoretto (2011) encontrou em sua pesquisa o dado de que os idealizadores do projeto dos CICs se identificavam com a vertente garantista do Direito, em relação à justiça restaurativa alguns dos profissionais envolvidos com a pauta ouvidos pela pesquisa, além de também se identificarem com o garantismo estão ligados à associações de cunho filosófico como a Palas Athenas.

A Palas Athenas é uma organização da sociedade civil sem fins lucrativos, fundada em 1972, cuja missão, de acordo com informações fornecidas pela própria instituição é promover, agenciar e incubar programas e projetos nas áreas de Educação, Saúde, Direitos Humanos, Meio Ambiente e Promoção Social: “com a finalidade de aprimorar a convivência humana por meio da aproximação de culturas e articulação dos saberes”. Além da promoção de projetos e eventos, a organização conta ainda com uma editora própria.

Os garantistas também estão em consonância com muitas das propostas da justiça restaurativa. Alguns entrevistados, operadores do Direito que participaram da implantação do novo modelo no país, a partir de posições e cargos assumidos no Executivo, relataram em entrevistas que se identificavam com a vertente garantista.

O garantismo, que é considerado um discurso marginal na área do Direito, diz respeito a um conjunto de teorias do Direito Penal e Processo Penal que realiza uma releitura do juspositivismo clássico, a partir de uma perspectiva racional-positivista de matriz iluminista, elaborada pelo jurista e filósofo italiano Luigi Ferrajoli. 
Mais especificamente, o garantismo surge num contexto de esvaziamento das principais teorias clássicas da Constituição e da norma, a partir da concepção de alguns operadores jurídicos que tomam o Direito, acima de tudo, como garantia. A teoria garantista calca-se, então, no respeito à dignidade da pessoa humana e seus direitos fundamentais, com sujeição formal e material das práticas jurídicas aos conteúdos constitucionais.

Direitos fundamentais que, nessa perspectiva, seriam invioláveis e que não somente devem ser respeitados e atendidos como também garantidos em sua máxima extensão. Tratase de uma definição de teoria geral que estabelece a garantia aos Direitos Fundamentais como condição de existência e validade de qualquer ordenamento jurídico, alcançando todos os cidadãos de modo universal. Ferrajoli cita como universais, e por conseqüência, fundamentais: a liberdade pessoal, liberdade de pensamento, os direitos políticos, os direitos sociais e direitos equiparados, bem como, as garantias processuais penais.

Estamos falando, portanto, de uma doutrina penal que conforma o poder punitivo do Estado ao respeito estrito a todas as garantias de ampla defesa do acusado e à indivisibilidade dos direitos humanos:

O discurso dos garantistas, críticos à função de repressão das classes populares pelo Estado penal, manifestava preocupação com a justiça social, além da justiça formal, e com a arbitrariedade exercida por agentes do Estado na persecução e execução criminal, sobretudo contra as classes populares. Realizavam a defesa de um direito que fosse sensível aos problemas do homem comum. E essa orientação os colocava em proximidade a grupos políticos externos ao campo jurídico, como a esquerda católica e defensores de direitos humanos (SINHORETTO, 2007, p. 160).

O legado da corrente do garantismo, onde a atuação do profissional do Direito, especialmente a do juiz, não deve se descolar do contexto social de marginalização em que foi produzido, foi notado no desenrolar da pesquisa.

As origens da justiça restaurativa remontam também ao abolicionismo penal, ainda que os dois movimentos apresentem diferenças substanciais. Enquanto a justiça restaurativa admite a utilização do cárcere para um reduzido número de delitos e segue conferindo importância à conservação das garantias processuais e penais, o abolicionismo, como o próprio nome sugere, propõe não só uma alternativa à pena de prisão, mas uma total substituição do atual processo penal (PALLAMOLLA, 2009). 
Também não é possível ignorar que a vitimologia exerceu grande influência sobre a corrente da justiça restaurativa (PALLAMOLLA, 2009). Vimos anteriormente como um dos principais pilares sobre o qual a teoria da justiça restaurativa se baseia é a recuperação do papel da vítima, que teria sido excluída do processo penal desde que o Estado assumiu a função da repressão do ato infracional contrário à lei.

Assim, uma das principais preocupações do modelo restaurativo é trazer a vítima de volta ao centro do processo de gestão do conflito, dando atenção especial às suas necessidades e oferecendo a oportunidade dela se empoderar no processo, podendo ter uma participação mais ativa na busca por soluções que sejam consensuais entre as partes afetadas pelo conflito.

Para concluir esta seção, cabe destacar que de toda descrição sobre a vinda da pauta da justiça restaurativa para o país, de acordo com o relato dos entrevistados e de como se deu o processo pelo qual ela veio a se instalar efetivamente em nosso país, a partir da estréia dos três projetos piloto, é possível concluir um ponto principal: que os relatos são construídos de uma maneira a se contar uma história, e nesse caso, uma história de sucesso. Não se pretende aqui fazer uma divisão que sugira a existência de duas versões distintas, uma que corresponde à realidade e outra imaginada, mas sim ressaltar a importância destes discursos que refletem os termos nos quais as iniciativas de justiça restaurativa foram pensadas por aqueles que viabilizaram os projetos iniciais.

A seguir, veremos como os relatos daqueles que apostavam no sucesso dos programas divergem do discurso daqueles que estão cotidianamente envolvidos com os programas e têm que lidar com as suas dificuldades contando, para isso, com poucos recursos.

\subsection{UMA HISTÓRIA DE DESAPONTAMENTOS}

Será exposta agora outra dimensão acerca destas iniciativas de justiça restaurativa, que começaram em 2005 com incentivo da Secretaria da Reforma do Judiciário e PNUD, como vimos através do depoimento de um de seus ex-assessores. Agora o foco recai sobre o relato de uma assistente social do programa de São Caetano do Sul (SP), que foi um dos três projetos pilotos, obtido através de uma entrevista.

Um primeiro aspecto a ser ressaltado sobre o encontro com esta profissional é que dela resultaram importantes atualizações para a pesquisa. A primeira informação que a interlocutora forneceu é que não estariam mais acontecendo círculos na escola Padre Alexandre Grigoli, enviados pelo Fórum. Como a dinâmica dos programas se altera com 
bastante frequência é difícil dizer se a situação se mantém a mesma até a conclusão deste trabalho. A entrevistada afirmou ainda que as três facilitadoras que restaram no programa estariam agora atendendo casos enviados pelo juiz ou promotor em um CREAS da cidade (Centro de Referência Especializada de Assistência Social).

Como ressaltado anteriormente, o diálogo com as facilitadoras estava prejudicado desde que questionei sobre os dados dos programas. O juiz as teria advertido de que não podiam fornecer mais informações, de modo que depois desse espisódio passaram a me evitar e não mais me avisar quando aconteceria um círculo.

Outra importante informação é que, segundo a assistente social, o próprio juiz teria pedido remoção da sua vara e estava tentando uma transferência para São Paulo.

Como vimos anteriormente, os juízes das respectivas localidades em que foram implantados os programas piloto são os principais incentivadores da pauta da justiça restaurativa nos locais. Uma das principais críticas dirigidas às iniciativas, de acordo com o ILANUD (Instituto Latino Americano das Nações Unidas para o Desenvolvimento), órgão que realizou a primeira avaliação dos projetos piloto, era que os programas estavam fortamente vinculados à figura dos juízes implementadores do modelo. Disto decorre que os programas ficam dependentes destes profissionais para continuarem.

Além disso, como pontuei anteriormente, o principal motivo de os programas não terem continuidade é o fato de seus principais profissionais atuantes se deslocarem nas carreiras, muitas vezes afastando-se dos programas para irem ocupar posições mais distantes das iniciativas. Dessa forma, sem seus patronos os programas se enfraquecem e, como ocorreu em alguns locais, acabam por se extinguirem. Isso mais uma vez vem a demonstrar como a pauta da justiça restaurativa pode impulsionar a carreira de alguns de seus profissionais, sem que necessariamente aconteça o mesmo com a pauta, que se debilita ao invés de se fortalecer.

Em algumas entrevistas realizadas, os interlocutores também ressaltaram esse aspecto, afirmando que as iniciativas eram muito personalizadas. Afirmou-se que em muitas vezes não se chegava a falar o nome do programa, mas sim o programa do dr. (nome do juiz) e isto seria na opinião deles uma fragilidade para os programas.

Resta então aguardamos para saber se o programa em São Caetano do Sul prosseguirá mesmo com a saída do juiz, se isto se concretizar.

Também foi interessante observar do relato desta assistente social toda uma história acerca de sua experiência com a justiça restaurativa em São Caetano do Sul. Ela foi 
inicialmente para a Vara da Infância e Juventude deste município justamente porque queria participar do programa de justiça restaurativa. De acordo com seu depoimento:

“(...) Se eu não estiver enganada, em 2006, eu fui para um evento da justiça restaurativa lá em São Caetano. O doutor promoveu um seminário internacional, vieram pessoas do Japão, do Canadá, da África, vários locais do mundo onde já estava acontecendo a justiça restaurativa. Ele fez esse evento e eu fiquei sabendo, fui lá participar. Tinham muitos profissionais e a comunidade, que é o foco. Puxa, quando eu fiquei sabendo, gente! Os moradores se interessando, a comunidade se interessando. Fui para lá. Daí eu fiquei impressionada porque, assim, tinha um brilho no olho das pessoas; e assim, o local que eu fui, que era numa escola, num auditório, lotado. Eu gostei muito; assim, os moradores ali, assim, num... nessa horizontalidade, tratando com juízes, tratando com outras pessoas, né; porque, assim, quem é que, de certa forma, deve exercer, deve participar, deve acompanhar; que, mesmo que mantém os órgãos públicos, somos nós, o povo, né".

A fala da entrevistada reforça o argumento exposto neste trabalho de que os discursos que sustentam a justiça restaurativa são sempre inicialmente de sucesso. Isto ocorre não somente para tentar angariar o apoio de cada vez mais interessados, mas porque efetivamente o aparato filosófico da justiça restaurativa é bastante auspicioso, ainda mais se levarmos em conta que grande parte destes profisionais, que estão buscando alternativas para a execução de seus trabalhos, estão minimamente descontentes com a atual situação do nosso sistema de justiçae com a consequente realização de seus trabalhos.

Outro ponto que chama a atenção neste excerto da entrevista é quando a assistente social menciona o clima de horizontalidade entre a população e os profissionais do Direito dos mais diversos segmentos de carreira. Essa é uma das principais críticas dirigidas ao nosso sistema de justiça oficial, a de que existe uma verticalidade e uma distância simbólica entre a população geral que procura ou é impelida a procurar as vias de acesso à justiça e os operadores do Direito.

Mas, a despeito do início promissor, como descrito pela entrevistada, a continuidade de seu relato vai nos mostrando todas as decepções (expressão utilizada pela própria interlocutora) pelas quais vai passando ao longo do tempo, trabalhando neste local:

"Porque, por exemplo, a primeira coisa que eu percebi, que eu não sabia. É que São Caetano do Sul, com essa história de ser a melhor cidade do Brasil... Mas é tudo maquiado, eu percebi. Para manter esse ranking, ela meio que maquia; então, assim, ela nega o problema, nega 
alguns problemas. É. Então, eu acho que isso já é a primeira dificuldade, porque um local que nega o problema (...)"

Como vimos no capítulo da tese dedicado ao programa de São Caetano do Sul, a cidade é renomada pelos bons índices apresentados, sendo a que apresenta melhor IDH (Índice de Desenvolvimento Humano) nos últimos anos.

Além desta, outra decepção é quando a interlocutora se depara com a realidade do programa de justiça restaurativa neste local, suas dificuldades, sua falta de estrutura, falta de financiamento e sustentado no voluntarismo das mediadoras que realizam os círculos:

"E daí, o quê que depois eu... quando eu cheguei lá, observei? Aquelas quarenta pessoas que tinham sido capacitadas, na comunidade, só restaram três."

"No início, elas ficavam na escola; isso, também foram outras pessoas que até comentaram porque quando eu comecei a ir na escola, elas já tinham, por exemplo, um lanchinho que era fornecido pela Prefeitura, e a água; mas, antes, no início, elas nem tinham esse lanchinho. (...) Nada. Nada. Então, como é que você quer que algo vá para frente, se você não oferece um mínimo, infraestrutura (...).”

Outro momento de desapontamento da entrevistada remonta a uma greve de funcionários do Fórum em 2010, momento em que ela entrava em contato com a pauta da justiça restaurativa:

"Então, o quê que aconteceu? Em 2010, nós tivemos uma greve de 127 dias, o Judiciário passou por essa greve; e durante a capacitação da Justiça Restaurativa estava rolando a greve; então, eu fiquei super, assim, em conflito, por que? E não só eu, as minhas amigas também, que também estavam se capacitando na Justiça Restaurativa; porque, assim, a gente estava analisando, o Judiciário está propondo algo que até é inovador, porque a gente quer sair desse modelo da punição e ir para o diálogo, a gente quer o respeito, a gente quer construir algo junto. Aí esse antigo Presidente do Tribunal, que era da greve, radicalíssimo, não dialogava conosco; assim, nós invadimos... nós, assim, eu estou dizendo, nós servidores, né; teve a ocupação de dois prédios, na época, ocupamos o Palácio da Justiça, ocupamos o prédio do Fórum João Mendes, veio gente de Brasília (...) Mas, assim, ele não dialogava de jeito nenhum com a gente, a gente tentando (...) Então, assim, o quê que aconteceu? Nós ficamos nesse clima de conflito; porque, assim, como é que eu quero me capacitar em Justiça Restaurativa se, na prática, a Justiça, a Casa da Justiça não dialoga conosco? Porque é a primeira coisa." 
Sua quarta decepção foi com o próprio magistrado que lidera o programa. Isto porque se trataria de um juiz que apóia, ao menos supostamenete, dada sua liderança do programa, a pauta da justiça restaurativa, mas, simultaneamente, na execução de seu trabalho diário, dá sinais de ser um profissional com orientações diferentes das propostas pela teoria que embasa o modelo restaurativo. Trata-se de uma situação vivenciada pela assistente social durante a realização de seu trabalho; ela afirmou que muitas vezes atendia jovens em conflito com a lei que chegavam até ela algemados:

"E eu cheguei até, inclusive, a fazer uma consulta para o atual Presidente do Tribunal de Justiça, que tem um link lá, "Fale com o Presidente", na Intranet, perguntando isso: "Por quê que eles estavam vindo algemados, se existia a Súmula Vinculante, se não estava em contradição com a Súmula Vinculante". Aí que veio a resposta, que ele me mandou, que assim: "Que essa questão da excepcionalidade estava a critério do Juiz". Aí eu fiz uma réplica para ele: "Porque o senhor entende, no seu entendimento, todos os adolescentes em conflito com a lei virem algemados é excepcionalidade?"

Além desta questão dos jovens serem atendidos algemados pelos profissionais, a assistente social falou também sobre a escuta especial (em relação à qual é contra, posição diferente da do juiz, pois, em sua opinião o trabalho das assistentes sociais, seus relatórios, não deveriam ser utilizados como prova para a incriminação do acusado): "Como é que você pode pensar em algo que não seja na linha punitiva, daí você tem o Depoimento Especial que o objetivo é encarcerar?".

Além disso, a entrevistada passou por outra situação, quando lhe foi pedido pelo policial militar que acompanhava um adolescente para ser atendido (cabe destacar aqui que é a Polícia Civil que deve encaminhar o jovem e não a Polícia Militar) que ela atendesse o adolescente de portas abertas (negando um direito do adolescente que é a sua privacidade) ou se se negasse, que assinasse um termo se responsabilizando por uma eventual agressão por parte do jovem. A entrevistada questionou essa decisão e questionou ainda a noção de periculosidade associada ao adolescente autor de ato infracional:

“(...) porque o adolescente em conflito com a lei, ele não é um elemento perigoso, por quê que eu tenho que atender o adolescente, ou com a porta aberta, e negando a ele a privacidade da história de vida dele. Só com ele é isso? Com nenhuma outra pessoa eu tenho que fazer isso? Eu atendo pessoas que eu vejo como muito mais complicadas e que poderiam me agredir, do que o adolescente em 
conflito com a lei. Agora, por quê que a gente tem que estigmatizar o adolescente em conflito com a lei?"

A situação descrita acima resultou em uma reunião com o juiz da Vara da Infância e Juventude e um representante de segurança pública. Nessa reunião, a entrevistada descreve como o agente da polícia falava continuamente sobre a escolta de presos, falando repetidamente o termo "preso". Isso incomodou a entrevistada que argumentou:

“Aí eu falei para o doutor: "Doutor, mas não é 'o preso', é um adolescente, ele não é um elemento perigoso, se a gente pensar num elemento perigoso - eu até falei -, o senhor sabe melhor do que eu, esse é o Código de Menores, ele é um adolescente em conflito com a lei, mas ele é um sujeito de direitos, ele está numa fase muito peculiar do seu desenvolvimento, ele não é um preso, ele ainda tem direito a toda aquela parte que é jurídica, que é de esgotar o processo, ele tem direito lá ao contraditório, a ampla defesa, ele tem direito a isso".

Como a decisão foi a de que a assistente social devia atender o adolescente de portas entreabertas, a decisão da entrevistada foi a seguinte:

"Eu falei assim para ele: "Então, doutor, eu... só que eu vou informar a família e o adolescente, que ele tem o direito a sua privacidade; e o adolescente... e se ele quiser, ele pode processar o Estado, por meio do seu defensor, eu vou registrar...". Eu falei para ele isso: "Eu vou registrar isso nos meus relatórios". E estou fazendo isso, registrando em todos os meus relatórios; se mais tarde, ele quiser entrar com um processo contra o Estado, ali está registrado, que ele tinha o direito e esse direito estava sendo violado".

O perfil do juiz, montado pela entrevistada corrobora o discurso que ele proferiu em um workshop sobre justiça restaurativa em casos de abuso e violência sexual; na ocasião ele fez a seguinte comparação: disse que quando um adolescente que cometeu um ato infracional responde em juízo, a família fica ao seu lado, (por se tratar de uma relação totalmente assimétrica: de um lado o adolescente, do outro o Estado), mas quando ele participa de um círculo restaurativo é diferente, a família não fica ao seu lado, mas passa a questionar sua atitude também. Essa é uma posição contraditória já que apoia métodos mais consensuais de administração de conflitos, mas o motivo parece residir no fato de que no círculo o controle das condutas poderia ser mais eficiente, dada a pressão exercida pelos familiares presentes.

Também foi possível inferir do depoimento da entrevistada que o cumprimento das decisões acordadas no círculo restaurativo, para a restauração das relações, geralmente não é concretizado. Quando se trata de pedir desculpas, ou apenas um ressarcimento financeiro (a 
imposição de uma compensação financeira como solução para o conflito é uma questão que emergiu durante a entrevista) o acordo é cumprido. Mas a situação esbarra no atendimento social, quando, por exemplo, o adolescente passa a depender de outros órgãos ou instituições para um eventual curso profissionalizante, ou estágio, atendimento psicológico, entre outros. Quando fica acordada no círculo uma restauração que passe a depender desses outros serviços o processo de reparação do problema fica inconcluso.

Nesse sentido, a assistente social entrevistada admitiu também que existe uma preferência para que os acordos se reduzam à questões monetárias, sempre que esta for uma possibilidade para o caso.

Sinhoretto novamente encontrou uma situação análoga nos CICs:

Outro tipo de caso atendido pela polícia no CIC envolve relações conjugais desfeitas e conflitos familiares. Diferentemente do esperado de uma instância do aparato penal, o conteúdo central administrado não é a violência doméstica ou conjugal. As narrativas de violência apenas compõem um cenário em que as questões patrimoniais ganham relevo: divisão da propriedade dos bens, renegociação do pagamento de pensões, definição de papéis e de condutas. O traço típico do serviço policial observado no CIC é a desconstrução da violência conjugal como foco do tratamento do conflito e o privilegiamento das questões patrimoniais envolvidas na dissolução do casal $(2014$, p. 52)

Embora não seja da alçada da polícia mediar conflitos, estudos sociológicos na áera há muito têm demonstrado que informalmente esta instituição faz este papel na gestão destes tipos de conflitos cotidianos. No caso da pesquisa de Sinhoretto, não foi somente neste tipo de atendimento prestado pela polícia que ela pôde observar a mobilização do ritual no sentido de direcionar a resolução do conflito para questões monetárias; a pesquisadora encontrou a mesma situação nos rituais de administração de conflitos praticados por outras instituições:

Se o interesse de regulação do uso da violência física não é traço marcante da atuação policial no CIC, tampouco ele aparece na atuação do Judiciário. A criação dos serviços alternativos de justiça orientouse para ampliar os canais de tratamento dos conflitos patrimoniais e econômicos individuais. Mesmo nos conflitos interpessoais no âmbito da família, do casal ou da vizinhança, é sempre a dimensão econômica dos conflitos que encontra respaldo, o que corresponde às exigências da circulação - ainda que minúscula da riqueza $(2014$, p. 53).

De acordo com a autora, a análise das audiências de conciliação dos juizados (e mesmo das de instrução) revelou uma clara tendência em privilegiar a discussão das questões econômicas (quem deve, quanto e qual a forma de pagamento) e negligenciar, ou até mesmo 
bloquear, a discussão das questões subjetivas, de reconhecimento e morais que emergem no processo do conflito.

Assim, de acordo com a autora, a lógica que predomina entre os diversos serviços e atores institucionais presentes nos CICs atribui máxima relevância ao tratamento das questões patrimoniais nos conflitos do cotidiano das periferias paulistanas e a irrelevância da administração do uso da violência física, seja naquilo que é realizado pela Polícia Civil, pelo Ministério Público, Poder Judiciário ou até mesmo junto à câmara de mediação, que representa a via mais informal de gestão do conflito dentro do quadro do CIC.

Acompanhamos, portanto, através do relato da assistente social toda uma história de sucessivas decepções com o programa do qual participa. Se inicialmente ficou marcado em seu relato que justamente o que a levou a ir trabalhar naquela localidade foi o programa de justiça restaurativa, depois, ao longo do tempo, a realidade do programa, sua falta de estrutura, e a convivência com colegas de orientações profissionais diferentes da sua a levaram a se decepcionar com a iniciativa.

Esta situação diverge do quadro pintado pelo primeiro entrevistado, que, participando dos momentos de primeiro contato da Secretaria com a pauta e viabilizando a criação dos projetos piloto, sustentava um discurso exitoso em relação ao modelo.

Além de apresentarem dois olhares diferentes sobre o mesmo objeto, ocorre também que, diferentemente da assistente social entrevistada, que ocupa uma posição periférica no contexto, o defensor público e ex-assessor da Secretaria teve a possibilidade de avançar na carreira a partir de seu envolvimento com a questão da justiça restaurativa. No entanto, a própria justiça restaurativa, diferentemente, não consegue alcançar novos patamares.

A seguir, veremos com mais detalhes como ela pode na verdade estar aumento as possibilidades de expansão da rede de controle social, não conseguindo escapar, assim, dsa lógicas que regem nosso atual sistema de justiça criminal. 
CAPÍTULO 5:

PROBLEMATIZANDO A NOÇÃO DE CONTROLE SOCIAL 
Alvarez (2004) problematizou o uso do conceito de controle social no âmbito das ciências sociais. Seu argumento seria o de que se o termo tem sido amplamente empregado em discussões que extrapolam o universo acadêmico, seria preciso então recuperar aspectos da trajetória do pensamento social por trás desta noção, aparentemente homogênea, para que não se percam questões importantes que estão nesta agenda de pesquisa.

Foucault foi um autor capital para este campo de estudos, pois promoveu um deslocamento nas análises que se detinham sobre o poder. Ele mostrou como, diferente do que os autores argumentavam anteriormente, que o poder teria um centro a partir do qual se emanaria - na verdade o poder não está localizado em pontos específicos. Foucault (2001) se detém sobre o como do poder, mostrando como ele é na verdade algo que exerce por toda a malha social e sempre em contextos cambiantes.

Seria preciso fazer o mesmo exercício com a noção de controle social. O senso comum aponta para aspectos negativos que estariam atrelados a esta noção, ou positivos, mas sempre no sentido de se atribuir valores ao termo. Torna-se necessário transcender análises deste tipo e evidenciar as nuances presentes no conceito. O controle, assim como o poder, é produtor, ele pode produzir, por exemplo, efeitos de verdade, saberes, práticas ou subjetividades.

O presente texto trabalha esta noção do controle social, uma vez que esta esteve presente em todos os momentos da pesquisa. Se a própria bibliografia em torno destas novas formas alternativas de gestão de conflitos aborda a questão, ela igualmente aparece nos eventos e workshops sobre o assunto, além de os próprios círculos restaurativos assistidos sucitarem a questão.

Há autores que enxergam, nestas iniciativas de justiça alternativas, uma nova forma de exercer um controle social sobre uma população específica a quem interessaria a muitos controlar, disciplinar, gerir. Nesse sentido, é preciso ter em conta a existência de uma linha de estudos na área (GARLAND 2008, HALLSWORTH 2012, NADER 1994) que aponta para uma expansão da rede do controle social, que teria sido possível a partir de um movimento de crítica sobre formas punitivas mais violentas, presentes na sociedade em séculos anteriores. Estes autores problematizam a questão aos mostrarem como essas novas formas de controle mais informais não são tão amenas como a princípio se poderia supor, somente mais sutis.

Outros, de maneira diferente, acreditam que tais iniciativas podem realmente abrir novas possibilidades de se repensar questões enraizadas no direito penal moderno; para eles, a justiça restaurativa poderia efetivamente tensionar aspectos fundantes do estado democrático de Direito, promovendo, assim, mudanças no tocante à punitividade do sistema. São autores que, de forma diferente, apontam para o fato de que, se de um lado há um movimento de 
recrudescimento penal, maior punitivismo, e uma população insatisfeita que exige penas mais duras e eficazes; de outro, um olhar mais atento poderia verificar iniciativas pontuais mais democráticas, que podem trazer resultados bastante positivos (AZEVEDO 2006; ALMEIDA 2012; PIRES 2013).

Por isso, a despeito das críticas que o presente estudo coloca, é preciso atentar para um importante contraponto que a justiça restaurativa faz ao sistema de justiça comum para que não se percam, em meios às críticas, possibilidades inovadoras no que diz respeito ao acesso à justiça e à administração de conflitos, ou, mais ainda, que as críticas venham a reforçar um discurso refratário a mudanças no sistema de justiça penal.

Existem ainda aqueles autores que atribuem ao modelo alternativo da justiça restaurativa a qualidade de instaurarem um novo tipo de controle social (BRAITHWAITE, 1989). Para estes defensores do modelo, o controle social não só pode como efetivamente deveria ser encarado de uma forma positiva; são autores que não estão dialogando no campo das ciências sociais e procuram mais disseminar o modelo. Veremos adiante, na verdade, como esse discurso mescla noções de controle social, disciplina e apoio.

Podemos inferir do exposto até o momento que existem diferentes perspectivas relacionadas ao controle social. Para capturar as diversas noções em torno deste tema, a participação em workshops e seminários, a respeito de métodos inovadores de administração de conflitos, foi fundamental.

Em alguns workshops de divulgação da justiça restaurativa, foi possível observar, por exemplo, falas que tentavam indicar a importância da presença dos familiares dos adolescentes no procedimento, pois, diante dos pais, os ofensores tenderiam a se responsabilizar e a se comprometer mais. Mas o que fica subentendido neste tipo de discurso é que o constrangimento seria o fator responsável pela conscientização e comprometimento do indivíduo infrator.

Um exemplo deste tipo de argumento é a seguinte fala extraída de um material sobre justiça restaurativa divulgado em um evento assistido: "Um sermão do juiz é ineficaz porque o agressor não tem uma conexão com essa pessoa, mas as lágrimas de sua mãe, sua esposa ou sua filha são uma influência mais poderosa, porque o agressor tem uma relação concreta e antiga com elas". Ou seja, somente o vínculo emocional que o acusado possui com as pessoas de sua família, presentes no procedimento, conseguiria demovê-lo.

Ademais, um juiz relatou em outro evento que, em sua opinião, quando um infrator é julgado pelo sistema de justiça comum, a família o defende, fica ao seu lado, mas quando acontece um círculo restaurativo a família, de forma diferente, tenta educar. De acordo com 
seu depoimento, é como se a família dissesse ao jovem que se ele fez, precisa assumir seu ato e cobra a responsabilização e assunção da culpa.

Esta questão é tão pertinente no campo de estudos da justiça restaurativa, que os autores chegam a empregar um termo específico para a situação: é a chamada "reintegrative shaming". Braithwaite (1989) afirma que para que a autoimputação seja internalizada pelo sujeito que cometeu um delito é necessário que a "vergonha reintegradora" faça parte do processo.

O conceito de reintegrative shaming foi elaborado por Braithwaite em Crime, Shame and Reintegration (1989). De acordo com este autor "A vergonha é vista como uma sanção poderosa que, afirma ele, pode ser mais efetiva do que as formas convencionais de punição centradas em torno das estratégias de retribuição, detenção, incapacitação e reabilitação"68 Matthews (2006: 242).

Ou seja, desde a sua criação a vergonha reintegradora não tem entre seus objetivos a ideia de não se constituir enquanto uma sanção, pelo contrário, clama ser mais efetiva que as outras formas normalmente utilizadas pelo sistema de justiça criminal.

Ao mesmo tempo, é claro que se tivermos como ponto de referência para a comparação as teorias convencionais da pena, como mencionadas pelo autor, a vergonha reintegradora parece ser uma boa saída. Esta é, evidentemente, uma opção de observação, mas, utilizando a mesma estrutura de pensamento que Garcia (2013) utilizou em seu artigo quando faz a crítica da prisão, se compararmos a vergonha reintegradora, por outro lado, com que o que ela pode vir a ser, ou o que pode substituí-la, então, podemos apontar suas limitações; tudo depende do ponto de partida do observador.

Para reafirmar o valor da vergonha reintegradora, Braithwaite também argumenta que ela poderia colaborar para evitar uma potencial estigmatização do ofensor, já que os indivíduos são vulneráveis a reincidir e a se inserir em subculturas desviantes se se sentirem excluídos e/ou estigmatizados.

Mais uma vez fica perceptível no conceito do autor que existe um objetivo adjacente de controle social e de, consequentemente, evitar a reincidência.

Braithwaite afirma ainda que a: "Vergonha reintegrativa significa comunicar desaprovação para o ato com respeito, com esforços especiais destinados a evitar identidades

\footnotetext{
${ }^{68}$ Tradução livre da autora, no original: "Shaming is seen as a powerful sanction which, he claims, can be more effective than the conventional forms of punishment centred around the strategies of retribution, deterrence, incapacitation and rehabilitation".
} 
marginalizadas e para pôr termo à desaprovação com rituais de perdão e reconciliação ${ }^{69}$ ", (BRAITHWAITE, 2001, p. 39). Assim, com objetivos de reconciliação e perdão ficam claras também as matrizes de pensamento religioso intrínsecas nesta proposta da vergonha reintegrativa. Podemos encontrar a mesma inspiração católica na primeira obra de Zehr a respeito da justiça restaurativa, o já mencionado Changing Lenses.

Alison Morris (2001) é uma autora que critica o conceito de vergonha reintegradora, mas fala de remorso reintegrativo, o que mostra que as discussões conceituais em torno da justiça restaurativa parecem não conseguir sair dessas molduras explicativas baseadas em conceitos como vergonha, remorso ou culpa.

O fato é que se deu bastante atenção a estes sentimentos de vergonha e culpa, de matrizes católicas, mas outros sentimentos que podem surgir nestes rituais têm sido alvo de pouca ou nenhuma pesquisa, como pondera Matthews (2006).

Braithwaite usa ainda o Japão como um exemplo de como a vergonha pode operar em uma cultura comunitária para produzir um sistema efetivo de regulação, algo que foi bastante criticado no campo das discussões conceituais a respeito do modelo restaurativo.

Este autor parte também de uma distinção básica, entre uma vergonha que é excludente e outra que é reintegradora para explicar seu conceito. Seguindo a mesma linha de pensamento de Braithwaite, Bazemore (2006, p. 612) propõe ainda em artigo uma distinção entre a vergonha reintegradora e o que ele chama de vergonha estigmatizante. Neste artigo, o autor identifica uma linha teórica que trata da vergonha reintegradora que "diferentemente da vergonha estigmatizante, permitiria que o autor do delito, através da assunção da culpa e da reparação do dano, seja novamente reintegrado em seu meio social pelos membros da comunidade". Depreende-se também como este autor tem uma avaliação bastante positiva acerca da vergonha reintegradora e seu papel dentro do modelo alternativo da justiça restaurativa.

A presença e a participação em workshops e seminários sobre a justiça restaurativa durante a pesquisa permitiram um acúmulo de materiais como os que serão apresentados a seguir. Embora eles não constassem no plano de trabalho inicial do projeto de doutorado proposto, acabaram se revelando em uma importante fonte de dados para a pesquisa. Procurou-se analisar este material, à luz das sociologias da punição e da administração de conflitos.

\footnotetext{
${ }^{69}$ Tradução livre da autora, no original: "Reintegrative shaming means communicating disapproval for the act with respect, with special efforts to avert outcast identities and to terminate disapproval with rituals of forgiveness and reconciliation".
} 
Estes dados constituem-se em um material bastante rico, como também demonstra o seguinte slide, retirado de um material apresentado em um seminário internacional sobre justiça restaurativa. Este material ficou disponível no site da instituição que sediou o evento para que os participantes pudessem ter acesso:

Esquema 1 - Esquema de controle e apoio na justiça restaurativa

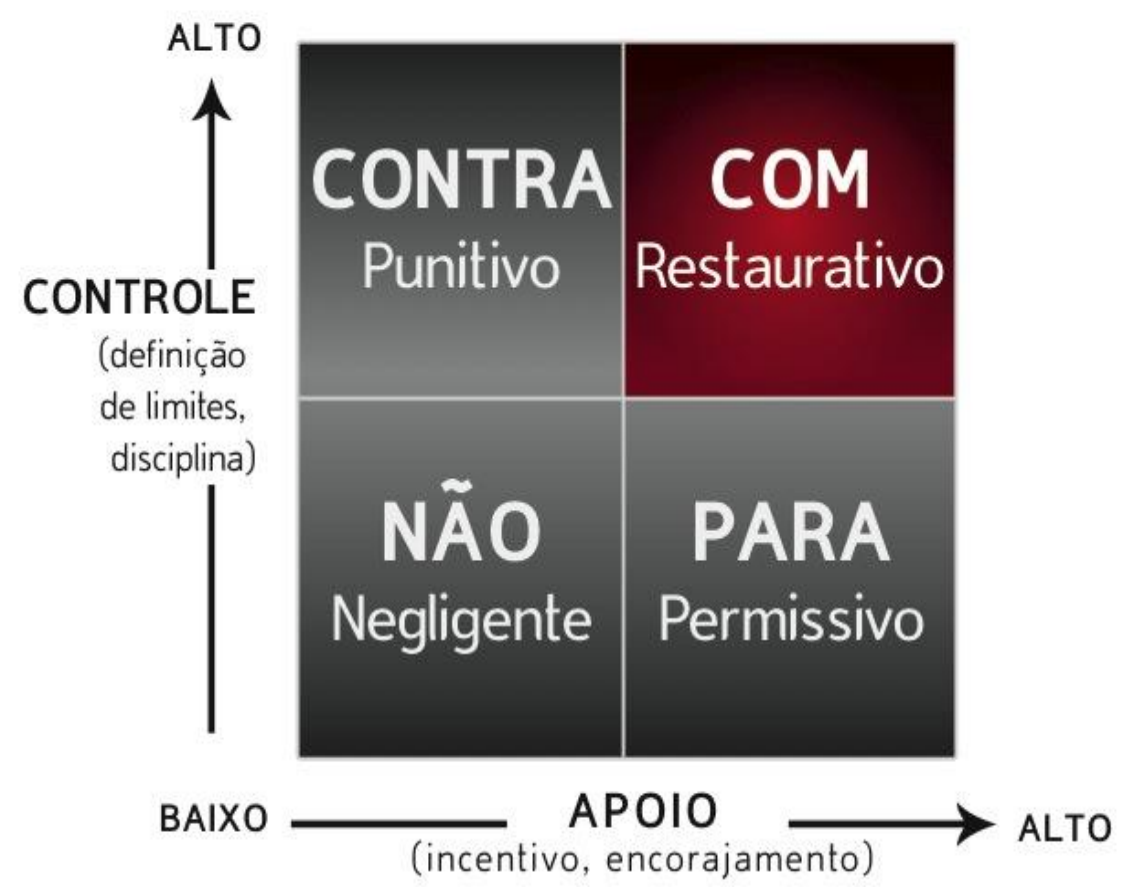

Fonte: www.iirp.edu

Este slide fez parte da apresentação de um representante do Instituto LatinoAmericano de Práticas Restaurativas (ILAPR), uma filial do Instituto Internacional de Práticas Restaurativas (IIRP), que detém também uma escola de pós-graduação, formação e organização de consultoria em práticas restaurativas de nível internacional, com sede em Bethlehem, Pensilvânia.

Este esquema interpretativo também reverberou no Brasil, como o demonstra a ilustração seguinte, retirada de um material de formação em práticas restaurativas do projeto Justiça para o Século XXI, que derivou do projeto piloto implantado no Rio Grande do Sul, no ano de 2005. 
É possível verificar, através da ilustração que está sendo reproduzida aqui, que se trata do mesmo esquema interpretativo:

Esquema 2: Esquema de controle e apoio (2)

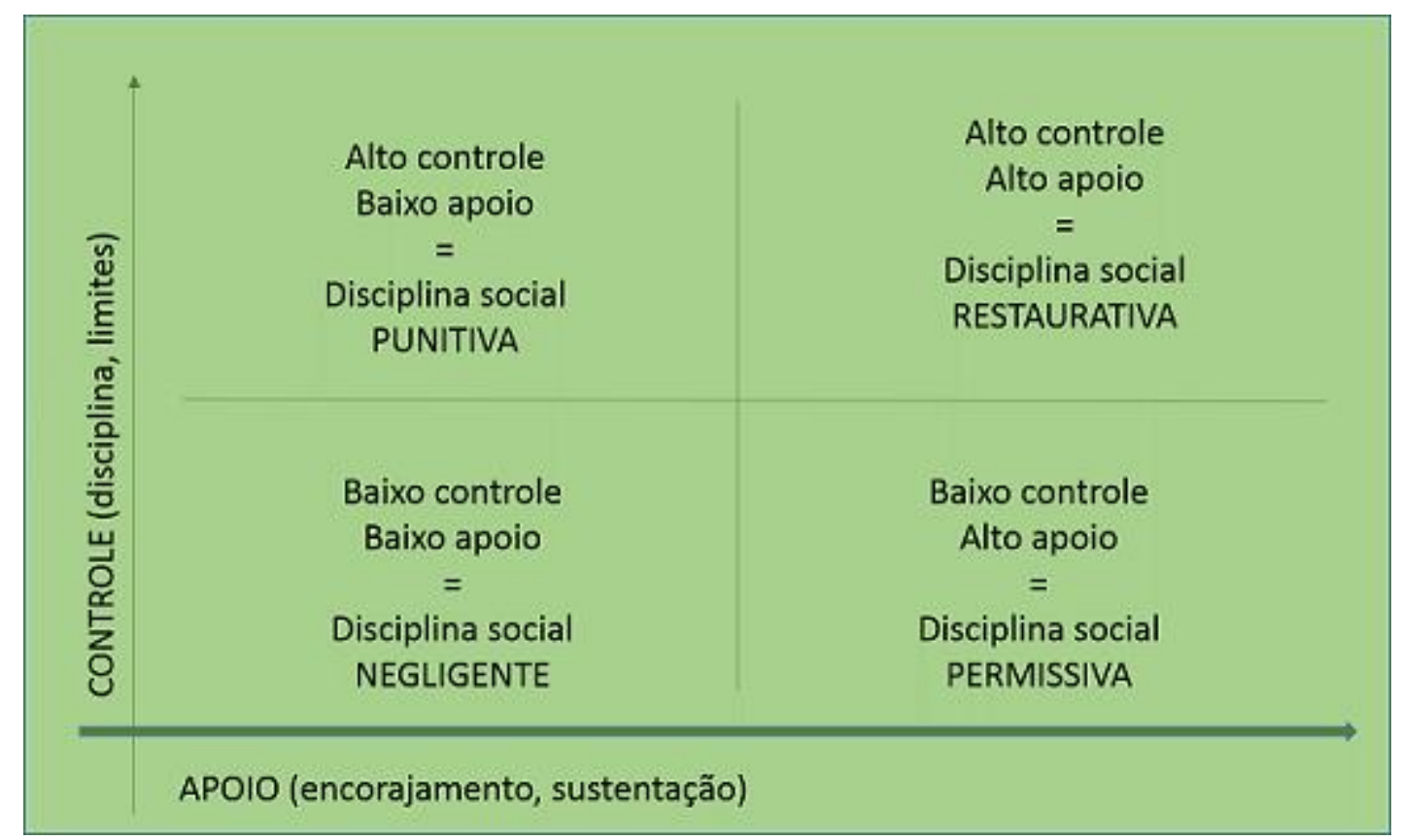

Fonte: manual justiça para o século XXI

Observa-se, a partir do esquema proposto por estas instituições, como a justiça restaurativa seria vantajosa por conseguir agregar alto nível de controle (entendido aqui como estabelecimento de limites e disciplina) e alto nível de apoio (encarado como incentivo e encorajamento).

O próprio juiz articulador do programa em São Caetano do Sul argumenta que a escola é um lugar neutro e por isso escolhido para a realização dos círculos restaurativos. Para o autor: "esses espaços devem simbolizar a possibilidade de: (entre outros) 4.) permitir um controle social informal (MELO, 2006, p. 72).

Falar em justiça restaurativa é falar, portanto, em controle. Se não de uma forma crítica, fala-se de controle como algo bastante positivo, como apontam alguns defensores do modelo alternativo, vide os exemplos acima expostos.

É possível questionar em que medida isto se relaciona a um contexto mais amplo de maior reforço punitivo, como apontou Hallsworth (2012). Então, para que a justiça restaurativa seja aceita, mostra-se como ela pressupõe disciplina e controle, ou seja, ela não deixa os ofensores totalmente livres como argumentam alguns críticos à justiça restaurativa 
que a identificam como um procedimento permissivo. Mas o resultado imprevisto disso é que ela pode acabar se constituindo em mais um tipo de punição (ainda que de outra natureza), o que contraria seus pressupostos teóricos básicos.

Os mesmos palestrantes do ILAPR ainda citam, em artigo disponível no site da instituição que sediou o evento, que as práticas restaurativas são: “uma disciplina para construir capital social e alcançar a disciplina social através da aprendizagem e tomada de decisão participativa”.

Outro exemplo bastante elucidativo é o seguinte excerto:

Por exemplo, um membro da segurança da comunidade ou da polícia que monitora um parque ou uma praça de esportes, em vez de expulsar crianças e jovens para garantir a tranquilidade, deveria interagir com essas crianças, procurar estabelecer conexões e confiança e promover uma mudança de comportamento positiva. Sua (tarefa, função, trabalho, atividade) missão deveria ser de controle (ter autoridade, estabelecer limites e expectativas...), mas com apoio (ser amigável, incentivando, dando suporte e orientação adequada, etc). (SCHMITZ; CHU, 2012, pp. 8-9)

Para estes teóricos da justiça restaurativa, os dois eixos do comportamento restaurativo são, portanto, controle e apoio. É uma forma de exercer um tipo de controle, em um processo conjunto com o indivíduo que se quer controlar, numa dinâmica em que a outra parte adquire papel ativo. $\mathrm{O}$ argumento mobilizado é o de que a autoridade, por exemplo, poderia ser mais bem exercida se não for imposta de cima para baixo, verticalmente, mas construída junto com os indivíduos.

Numa linha contrária, de vertente crítica a estes novos modelos alternativos de justiça, existem autores como Rose (2000), para os quais os processos de surgimento dessas inciativas, que investem na necessidade de indivíduos e comunidades assumirem maior responsabilidade por sua própria segurança, estão relacionados à expansão de uma racionalidade específica, que investe, principalmente, na escolha individual como uma forma de controle social.

É a partir de Rose (2000), autor fundamental para a discussão proposta, que se pode, então, passar a olhar da perspectiva da administração de conflitos para a de administração de pessoas. Ou seja, é possível pensar, a partir de Foucault, se não estamos diante de uma forma específica de gerir corpos, através da disseminação de uma noção de responsabilidade da comunidade sobre os indivíduos e a criminalidade e dos indivíduos sobre eles próprios. 
Cruikshank (1994) é outra autora que aborda a questão. Menciona o empowerment, que caracteriza programas sociais norte-americanos que se pretendem inovadores. $\mathrm{O}$ ângulo da intervenção política e social nesse caso é modificado: não são mais fatores estruturais como o desemprego, o alcoolismo e a criminalidade que devem ser resolvidos - pressupostos do welfare state -, mas categorias individuais e subjetivas como a autoestima e o respeito com si próprio $^{70}$, essenciais para alcançar esse empoderamento. Dessa forma, a exclusão torna-se uma condição subjetiva, relacionada ao modo pelo qual os indivíduos conduzem sua própria vida (OLIVEIRA, 2010).

Dentro dessa perspectiva, torna-se interessante recuperar a noção de difusão do modelo empresa entre os indivíduos, como apontou Foucault. Esta questão, que não foi tão exaustivamente trabalhada por pesquisadores que se detiveram em análises sobre os escritos deste autor, pode ser elucidativa para entender este processo de transferência de responsabilidades e expectativas em relação ao controle do crime para a comunidade e os agentes de forma individual (construção ética de novos indivíduos).

Dessa forma, apesar desta ligação do modelo informal com o campo estatal, todas as práticas de justiça alternativas têm uma característica em comum: todas representam iniciativas para fornecer justiça por canais que não são totalmente monopolizados pelo sistema de justiça formal, ou seja, deve ser levado em conta o fato de esse método alternativo trazer para o debate a questão de tentativa de transferência de poderes para a esfera civil ${ }^{71}$. (OXHORN, SLAKMON, 2005).

Nesse sentido, tanto a justiça restaurativa coloca como opção a mediação de conflitos sendo presidida por um agente da comunidade, eximindo-se assim da presença de um representante oficial da justiça, quanto enfatiza a responsabilidade da comunidade na manutenção de sua própria ordem.

Outra linha argumentativa no campo problematiza a concepção de pacificação social, um dos objetivos da justiça restaurativa. Assim, apesar de parte da literatura produzida sobre a justiça restaurativa ressaltar que conflitos são naturais aos relacionamentos humanos e que por isso devem ser tratados de forma reparadora e não repressiva ${ }^{72}$, é possível identificar uma

\footnotetext{
${ }^{70}$ Para saber mais sobre o assunto ver: GARLAND, D. A cultura do controle. Rio de Janeiro: Revan, 2008.

${ }^{71}$ Weneck Vianna trabalha com a questão trazendo para o debate a dimensão civil, ele atenta para as relações sociais envolvidas no problema. (Vianna, L. J. W; Vianna, L. W; Carvalho, Maria Alice Rezende de; Melo, Manuel Palacios Cunha; Burgos, Marcelo Baumann . A Judicialização da Política e das Relações Sociais no Brasil. 1a.. ed. Rio de Janeiro: Editora Revan, 1999. v. 01. 272 p)

72 De acordo com a escola de pensamento originada por Simmel e tendo como referência o livro Conflict and the web of group affiliations, de 1955, o conflito seria uma das formas centrais de interação, tendo, portanto, conotação positiva e distinguindo-se da noção de competição. Essa concepção positiva do conflito é muito
} 
linha de discussão que acredita que tal modelo de justiça faz parte de um movimento que busca, sobretudo, exercer um controle social, ao compreender os conflitos como situações essencialmente negativas, as quais devem ser combatidas. Essa concepção seria perigosa, na medida em que implica um controle social possível através do objetivo maior da instauração da paz social.

Para autores como Schuch (2006) e Nader (1994a; 1994b) a justiça restaurativa incita a discussão a respeito da racionalização das emoções e seu papel na condução de projetos civilizadores, ao propor, através da restauração dos laços sociais rompidos, a instauração da harmonia social.

Nader é uma antropóloga norte-americana que pesquisou as Alternative Dispute Resolution (ADR), nos EUA, conjuntamente a processos indígenas de composição de conflitos. A autora insere essas justiças conciliatórias dentro do que denomina "ideologias da harmonia" e argumenta que não se trata de formas revolucionárias de administração de disputas, mas antes de outro modelo de controle social.

Para Laura Nader (1994) os EUA, nas três últimas décadas, teriam passado de uma preocupação com a justiça para uma preocupação com a harmonia e eficiência, isto é, de uma ética do certo e do errado para uma ética do tratamento.

Segundo a autora, o entusiasmo transformador dos anos 60 nesse país foi substituído por uma intolerância em relação ao conflito: proclamou-se que os tribunais estavam abarrotados e que os advogados e os norte-americanos eram muito litigantes.

Além disso, a autora frisa que considerar a harmonia algo benigno em oposição ao conflito, que passaria a ser visto como algo a ser extinto, pode se constituir numa poderosa forma de controle social e político, como também já indicou Schuch (2006).

Garland (2008) é um autor que pode ainda complementar a discussão, pois foi capaz de ampliar a questão para além da perspectiva do poder. Este autor propõe uma abordagem pluralista e multidimensional da questão da punição, mostrando como ela envolve questões culturais e simbólicas, já que a punição, além de regular a conduta por meio da ação social física, também regularia significados, pensamentos, atitudes (ALVAREZ, 2006). Nesse sentido empregado pelo autor, podemos, então, discutir a existência de um tipo de punição dentro das iniciativas de justiça restaurativa analisadas que fogem à noção corrente de punição como algo que obrigatoriamente envolve a aplicação de um sofrimento ao culpável.

utilizada como base teórica dessas justiças que privilegiam o diálogo e autocomposição das partes, já que elas entendem o conflito como um momento possível de restauração de relações sociais desgastadas. 
Garland (2008) mostra também como a comunicação simbólica entre a instituição penal e o conjunto da sociedade se dá por meio de como as sentenças são pronunciadas ou publicizadas, como o juiz se refere a elas - ou seja, são nas práticas rotineiras que se manuseiam os significados da punição. No caso dos programas de justiça restaurativa não é o juiz quem conduz o procedimento, mas não é indiferente o papel que os chamados facilitadores de justiça assumem; isso traz implicações para o procedimento, mesmo que se embase em um tipo de autoridade diferente daquela exercida pelas figuras dos profissionais do Direito.

O modelo de justiça restaurativa, e a forma como vem sendo utilizada em programas no estado de São Paulo, constituem, portanto, um terreno fértil para discussões relacionadas ao poder, punição, disciplina e controle social por proporcionar a análise da dinâmica profissional relacionada às formas de resolução de conflitos considerados de menor potencial ofensivo ${ }^{73}$ e que envolvem geralmente adolescentes em conflito com a lei.

Além do mais, se na maior parte das vezes a justiça restaurativa têm se constituído mais em um espaço dentro do qual antigas práticas se consolidam, do que uma inovação no campo, como pretendem alguns, cabe questionar então por que motivos ela tem se mantido. Nesse sentido, faz-se necessário também atentar para os objetivos de apoio ao sistema formal de justiça, no momento em que tenta desviar dele crimes considerados de menor potencial ofensivo.

Ao mesmo tempo, é possível indagar se não estaria sendo utilizada um tipo de estratégia profissional, mobilizada para manter um status quo, ou seja, esse duplo movimento que o programa faz de retirar dos meios oficiais este tipo de conflito, ao mesmo tempo em que mantém um controle sobre estes pequenos atos infracionais permitiria ao profissional do Direito delegar para outros operadores, situados numa posição inferior na hierarquia profissional, conflitos que acreditam não fazer parte de sua expertise, sem, contudo, deixar de oficializar os casos.

Retomando a Rose (2000), não há mais apenas os tribunais para garantir a segurança aos cidadãos; a proteção contra o risco envolve agora investimentos em medidas capazes de operar uma reforma moral e uma reconstrução ética dos envolvidos na criminalidade. (OLIVEIRA, 2010) Isso abre espaço para um amplo espectro de técnicas psicológicas,

\footnotetext{
${ }^{73}$ As infrações de menor potencial ofensivo correspondem às condutas prescritas no Código Penal, para as quais a condenação prevista é inferior a dois anos de privação de liberdade ou pagamento de multas. Autores como Azevedo (2001) apontam para os significados embutidos em termos como "delito de menor potencial ofensivo", tentando indicar na verdade o descaso do sistema judicial para com certas demandas. (AZEVEDO, Rodrigo G. de. A informalização da justiça penal no Brasil. Civitas - Revista de Ciências Sociais, ano 1, n. 2, dez. 2001.)
} 
recicladas em programas para governar os excluídos, com experts que atuam com os juízes na aplicação de mecanismos de mediação de conflitos. Nesses procedimentos, o pressuposto da escolha ética é central e a relação que o indivíduo estabelece consigo mesmo é alvo desses profissionais (ROSE, 2000).

Das descrições dos casos assistidos, pudemos verificar como as facilitadoras de justiça exercem muitas vezes um papel moralizante sobre as partes em conflito. Nesse sentido, é preciso lembrar que, para Foucault (2001) o poder não se exerce somente pela "negação" (não deve ser, não deve fazer), mas pelas "afirmações" que passam batidas através dos processos de disciplinarização que permeiam nossas relações sociais.

Finalmente, seria preciso refletir também sobre o quanto a justiça restaurativa, contrariamente a tudo o que ela propõe, poderia estar na verdade aumentando o reforço punitivo. Autores como Pavarini (2002, p.111) discutem como a justiça restaurativa pode ser encarada apenas como sendo mais um instrumento na "caixa de artefatos" estatal, na tarefa de controle social. Nesse sentido, ao invés de transformar o sistema penal no sentido da sua redução, a justiça restaurativa incrementa as opções do Estado e aumenta o controle que ele mantém sobre a sociedade, como um "meio paralelo de ampliação do poder do estado de punir" (KARAM, 2004, p.32), que em nada contribui para a superação do sistema penal.

Como citado por Benedetti (2006) ela integraria, em realidade, o quadro de transformações atuais na política do controle, adequando-se aos três movimentos detectados por Cirino dos Santos (1981, p. 81): (i) a expansão geral do controle por um maior número de pessoas; (ii) a aceleração da passagem pelo sistema, abrangendo mais pessoas ao mesmo tempo; e (iii) a bifurcação, pela redução do rigor destinado a "crimes menos perigosos" para a legitimação da severidade reservada aos "crimes mais perigosos".

Conclui a autora que:

(...) a justiça restaurativa emerge como um mecanismo de despolitização que simultaneamente viabiliza a radicalização da repressão: ao mesmo tempo em que devolve certos conflitos à sociedade, permite, pela melhor alocação dos recursos disponíveis, uma maior eficiência repressiva ao Estado no gerenciamento desses e outros conflitos. (BENEDETTI, 2006, p. 512)

Este tipo de argumento, como defendido por Benedetti (2006), que vem no sentido de apontar como a justiça restaurativa tem, na verdade, aumentado o reforço punitivo e de como isso seria um dos seus efeitos imprevistos, pode ser questionável, e até mesmo difícil de ser comprovado. Esta pesquisa de doutorado, embora também não pareça ser suficiente para 
rechaçar o argumento, uma vez que se deteve sobre iniciativas bastante pontuais no estado de São Paulo, ao menos pode fornecer algumas pistas que colocam a afirmação em dúvida, já que todo o trabalho vem mostrando como a justiça restaurativa não consegue sair da marginalidade, tendo ainda pouco ou nenhum impacto sobre o sistema de justiça criminal.

Ao mesmo tempo, é preciso levar em conta que a justiça restaurativa, mesmo estando atualmente situada em uma posição marginal no campo da administração estatal de conflitos, tem cumprido um papel - como demonstrei ao longo da tese - que não é indiferente. Vimos como seus objetivos são claros, mesmo no discurso de seus fomentadores, no sentido de tentar evitar a judicialização de casos considerados pouco importantes para a prestação do serviço jurídico, especialmente casos que envolvem adolescentes do sistema público educativo. Assim, este modelo de justiça restaurativa tem sido pensado em nosso país para atuar sobre um público bastante particular, ao mesmo tempo em que operadores do direito podem delegar estes casos para serem resolvidos em outras instâncias mais informais, contando para isso com ritos conduzidos por leigos, sem que com isso haja perda de controle do Estado sobre esta pequena criminalidade. 


\section{CONSIDERAÇÕES FINAIS}

Ao longo da tese percorremos três dimensões relacionadas ao modelo da justiça restaurativa: seu conceito, as representações que os envolvidos detêm sobre este modelo de justiça e as práticas observadas em campo.

Em relação ao quadro conceitual da justiça restaurativa, foi possível verificar que, enquanto sua discussão teórica centrar-se sobre a dicotomia entre dois modelos diferentes de justiça (justiça retributiva e justiça restaurativa), ou sobre o que ela não é, como proposto por Zehr (2012), não conseguirá desvincular-se do modelo de justiça ao qual se opõe.

O fato de a justiça restaurativa se apresentar dessa maneira, paralela, ligada aos métodos característicos do sistema de justiça corrente acaba limitando sua própria potencialidade crítica. Mais que isso, acaba, na verdade, reforçando a centralidade do sistema de justiça penal, em nada contribuindo para que a maneira de pensar a punição por esse sistema seja superada.

Mas isso não acontece somente em seu nível teórico. A pesquisa também mostrou como o mesmo acontece com as representações e as práticas que acabam por reforçar a centralidade do Judiciário, minimizando ainda mais o modelo alternativo frente aos pares profissionais e à população atendida pelos programas. Assim, a despeito de seu potencial transformador, a justiça restaurativa ainda tem se defrontado com dificuldades para ser efetivamente implantada. As resistências com as quais têm que lidar reportam-se aos próprios operadores do Direito e população que é atendida pelos programas, que não entendem o modelo enquanto expertise (caso dos profissionais do Direito), ou como um benefício para os envolvidos (caso dos adolescentes e familiares participantes), ainda inscritos dentro um marco punitivo em relação à gestão de conflitos.

Foi possível igualmente verificar como estas iniciativas não estão rompendo com as lógicas do sistema de justiça comum, como a princípio se poderia supor. Em realidade, além de integrarem um quadro em que nosso sistema de justiça criminal continua sendo central, estão aumentando as possibilidades de expansão da rede de controle social, inaugurando configurações inéditas de programas que mesclam o formal e o informal, saber leigo e expertise.

As conclusões da pesquisa apontam, portanto, para o fato de que ainda que a justiça restaurativa se apresente como inovação, tensionando em alguns pontos o sistema de justiça penal ao propor uma nova forma de gestão de conflitos que desvia o foco da punição para a 
restauração das relações afetadas com o conflito, ainda assim tem um longo caminho a percorrer para que sua expertise seja traduzida em práticas transformadoras.

Nesse sentido, cabe lembrar novamente que os programas analisados apresentam muitos pontos vulneráveis: funcionam a custo praticamente zero, baseados no voluntarismo dos mediadores, pouca ou nenhuma infra-estrutura, falta de financiamentos, pressão por produtividade e bons índices, sem a legitimidade das instâncias oficiais.

A partir da pesquisa de campo empreendida, procurou-se também evidenciar as ambiguidades de um modelo "alternativo", porém mimetizador do modelo oficial. Foi possível observar ainda que nos círculos restaurativos são manipuladas diversas significações sobre o que é justiça oficial juvenil e a justiça restaurativa, de acordo com o repertório acessado pela facilitadora. A observação participante possibilitou verificar os momentos destas construções e o olhar atento para os casos permitiu verificar como esses significados, produzidos na micropolítica que envolve o cotidiano do programa, conectam-se a uma dimensão mais ampla associada a um contexto de crise do sistema de justiça e da retórica punitiva ou ressocializadora (FULLIN, 2011), especialmente no que concerne aos adolescentes em conflito com a lei.

Foi possível concluir, a partir das observações do trabalho de campo, que antes de ser uma forma alternativa de administração de conflitos, a justiça restaurativa está sendo praticada como um procedimento, uma etapa, no interior da forma judicial clássica de administração de conflitos, voltada ainda para a punição do indivíduo infrator.

Ademais, é preciso considerar que as diversas opções de meios de administração de conflitos praticadas hoje não são apresentadas igualmente a todos os cidadãos - elas são pensadas para públicos específicos, almejam tratar de conflitos também específicos e atendem a objetivos claros.

Mathiesen apud Benedetti (2006) alerta para a elementar, porém importante, informação de que uma alternativa só se afigura como tal quando entra em contradição e compete com o sistema antigo. Pode-se, a partir desta afirmação, questionar se da forma como vem sendo utilizada, nas regiões observadas do estado de São Paulo, a justiça restaurativa constitui-se enquanto alternativa, pois não parece contradizer o sistema de justiça corrente, ao contrário, reproduz aspectos concernentes aos ritos oficias; e também não compete com a justiça comum, de maneira diferente, se combina com ela, numa configuração institucional que chega até mesmo a ser ambígua.

Nesse sentido, as ambiguidades que a justiça restaurativa apresenta no contexto brasileiro já estavam presentes desde seu nascimento, ou seja, desde a criação dos projetos 
piloto em 2005. Isto acontece porque se, por um lado, no momento em que foi decidida a implementação destes projetos eles foram concebidos para serem iniciativas de sucesso, por outro lado, pelo fato de focarem em conflitos de baixo potencial ofensivo, que envolvem adolescentes do sistema público educacional, contando para isso com poucos recursos, tudo isto demonstra que ela também foi desenhada para ser algo marginal.

Além do mais, os limites que a justiça restaurativa enfrenta estão também relacionados à própria força do sistema de justiça penal moderno, que vem acompanhado de todo um conjunto de ideias baseadas na pena, na punição como resposta ao ato infracional. A justiça restaurativa abre, portanto, um espaço cognitivo para refletirmos a respeito da teoria da racionalidade penal moderna, como cunhada por Pires (2013).

Pires (2013) argumenta que a teoria da racionalidade penal moderna que está construída sobre uma observação inicial: a de que as teorias convencionais da pena (retribuição, dissuasão, denunciação, reabilitação carcerária ${ }^{74}$ ) que são sustentadas e valorizadas pelo sistema de direito criminal, constituem um obstáculo cognitivo à reconstrução-inovação das estruturas e processos do direito criminal concernentes às penas, ao mesmo tempo em que não dão apoio suficiente às sanções não carcerárias ou outras sanções que não visem a imposição de um sofrimento ao culpável.

Estas teorias da pena exercem, portanto, sobre o plano das ideias e das formas de legitimação, um bloqueio sobre a maneira de pensar uma reforma do direito criminal: elas eliminam a imaginação criativa dos criminalistas e os fazem "girar em círculo": Pires utiliza a figura da garrafa de moscas de Wittgenstein e de Watzlawick para ilustrar esse obstáculo $\operatorname{cognitivo~}^{75}$.

O conceito de racionalidade penal moderna se refere, portanto, a este sistema de ideias formado pelas teorias convencionais da pena que fazem referência a um problema de evolução em matéria de direito criminal. São quatro os componentes principais da racionalidade penal moderna: direito de punir definido como obrigação de punir e crítica do perdão; valorização das penas aflitivas ou de exclusão social; a supervalorização da pena

\footnotetext{
${ }^{74}$ Embora seja importante conhecer o que estas teorias modernas da pena propõem, onde convergem e onde se afastam umas das outras, o empreendimento escapa aos limites propostos por este texto. Para saber mais do assunto recomendamos a leitura de Pires, A. P., A formação da racionalidade penal moderna no século XVIII : Beccaria, Kant e o direito de punir, Petrópolis: Rio de Janeiro, Editora Vozes, 2014, (traduction portugaise de l'Histoire des Savoirs, vol. 2, Partie 1, p. 21-254: La formation de la rationalité pénale moderne au XVIIIe siècle, avec une révision de certaines formulations.)

${ }^{75}$ De acordo com Pires (2013) podemos dizer que estamos em presença de um obstáculo epistemológico (ou cognitivo) quando os hábitos profissionais ou as ideias que um sistema social julga (ainda) apropriados, bons ou interessantes, impedem a adoção, a generalização e o estabelecimento à longo termo de novos hábitos ou ideias melhores, estruturas e práticas dentro do próprio sistema.
} 
privativa de liberdade (prisão como pena de referência); e a desvalorização das sanções alternativas (GARCIA, 2013).

A recorrência enunciativa desta ideia da obrigação de punir forma a identidade penal do sistema de direito criminal moderno. Suas teorias sustentam que a pena deve ser aflitiva para ser uma verdadeira pena e que a sanção por reparação concernente à vítima não é uma pena (ou se porta mal como pena, exceto para as pequenas infrações): "Dentro das representações dominantes, aquilo que chamamos de punição deve procurar diretamente e intencionalmente a aplicação de um sofrimento ao culpável” (PIRES, 2013).

Nesse sentido, a justiça restaurativa apresenta uma contribuição importante, ela propõe, de maneira diferente, outras formas de resposta ao crime que escapam a esta noção cristalizada pelas teorias modernas da pena de que devemos sempre inflingir um sofrimento ao ofensor; ela propõe a reparação e até mesmo o perdão em alguns casos como um fechamento para o conflito, mas ainda não consegue sair da marginalidade frente à racionalidade penal moderna.

Teorias como esta nos mostram como estamos presos em um sistema de justiça penal que não consegue transformar seu quadro interno de funcionamento, baseados sobre um sistema de ideias próprio que não consegue vislumbrar outras possibilidades que não o estado presente das coisas.

Foi objetivo deste trabalho, portanto, discutir a justiça restaurativa, considerada uma forma alternativa de administração de conflitos, a partir das sociologias da punição e da administração de conflitos.

A metodologia utlizada foi qualitativa e a pesquisa partiu do estudo de caso de programas de justiça restaurativa que funcionam no estado de São Paulo, além de entrevistas com profissionais e observação participante de círculos restaurativos que aconteceram em uma escola na cidade de São Caetano do Sul (SP).

Como tese principal, a ideia apresentada foi a de que a justiça restaurativa só é aceita e se mantém, mesmo com dificuldades, por permitir que antigas práticas no Direito se mantenham. Ou até mais, pois como foi possível inferir, ela não somente tem aumentado o controle sobre atos que sequer chegavam a ser considerados crimes como também tem permitido que o profissional do Direito delegue para outros operadores, situados numa 
posição inferior na hierarquia profissional, conflitos que acreditam não fazer parte de sua expertise.

Também vimos como a pesquisa foi se aproximando cada vez mais de um estudo das diversas formas pelas quais a justiça restaurativa está sendo apropriada pelos mais diferentes grupos envolvidos com a questão. Um dos resultados disso foi a criação de um novo mercado voltado para as capacitações de futuros implementadores do modelo restaurativo. Sobre isso, segue a opinião de um entrevistado, ex-operador do Direito, hoje aposentado que esteve bastante envolvido com a pauta em seu início:

Com a justiça restaurativa acontece o mesmo que sucede com outras ilusões e esperanças humanas concentradas em um paradigma qualquer: a apropriação, pelo poder. Com a Justiça Restaurativa existe também uma ânsia de apropriação dela não só pelo Estado (Judiciário e/ou Executivo), mas também pela igreja, pelas universidades, pelo mercado, etc. Um grande risco, por exemplo, é uma privatização e terceirização da gestão de conflitos, como um nicho de mercado, com atropelo de direitos e garantias fundamentais. As universidades também procuram fechar o conceito em seus muros. A igreja a liga ao arrependimento, perdão e culpa. O Estado, por sua vez, não quer abrir mão de seu monopólio de poder, com a atitude de que os conflitos são matéria-prima patenteada aos burocratas bacharéis.

Assim, ainda que a tese tenha circulado por várias dimensões relacionadas à justiça restaurativa em nosso país, com especial atenção às iniciativas presentes no estado de São Paulo, cabe ressaltar, neste momento do texto, que não se deixa de ter em mente que este foi apenas um recorte escolhido dentre vários outros possíveis e que não capta, portanto, nunca a inteireza dos fatos. 


\section{REFERÊNCIAS BIBLIOGRÁFICAS}

ALMEIDA, Frederico. (2009) As elites jurídicas e a política da administração da Justiça no Brasil. Trabalho apresentado no $33^{\circ}$ Encontro Anual da Associação Nacional de PósGraduação e Pesquisa em Ciências Sociais. ANPOCS. Caxambu, 26 a 30 de out.

ALMEIDA, Guilherme. de. (2012) Acesso à justiça, direitos humanos e novas esferas da justiça. Contemporânea - Revista de Sociologia da UFSCar. São Carlos, v. 2, n. 1, p. 83-102, jan-jun 2012.

ALVAREZ, Marcos. (2004) Controle social: notas em torno de uma noção polêmica. São Paulo em Perspectiva, São Paulo, v. 18, n. 1, p. 168-176.

; SALLA, Fernando.; GAUTO, Maitê. (2006) A contribuição de David Garland: a sociologia da punição. Tempo Social. Revista de Sociologia da USP, São Paulo, v. 18 , n. 1, p. 329-350.

AMORIM, Maria Stella de. (2006) Juizados Especiais na região metropolitana do Rio de Janeiro. Revista da Seção Judiciária do Rio de Janeiro - SJRJ, n.17, p. 107-131, ago.

; BURGOS, Marcelo; KANT DE LIMA, Roberto. (2002) Os Juizados Especiais no sistema de justiça criminal brasileiro: controvérsias, avaliações e projeções. Revista Brasileira de Ciências Criminais. São Paulo: Instituto Brasileiro de Ciências Criminais, ano 10, n. 40, p. 255-281, out/dez.

A administração da violência cotidiana no Brasil: a experiência dos Juizados Especiais Criminais. (2003) In: AMORIM Maria Stella de; BURGOS, Marcelo; KANT de LIMA, Roberto (Org.). Juizados Especiais Criminais, sistema judicial e sociedade no Brasil: ensaios interdisciplinares. Niterói: Intertexto.

ASHWORTH, Andrew. (1986) PUNISHMENT AND COMPENSATION: VICTIMS, OFFENDERS AND THE STATE. Oxford J Legal Studies 6 (1): 86-122.

AZEVEDO, Rodrigo G. de. (2000) Informalização da justiça e controle social. Estudo sociológico da implantação dos Juizados Especiais Criminais em Porto Alegre. São Paulo: IBCCrim.

(2001) Juizados Especiais Criminais. Uma abordagem sociológica sobre a informalização da justiça penal no Brasil. Revista Brasileira de Ciências Sociais, v.16, n. 47:97-110, out.

. (2006) Prevenção integrada: novas perspectivas para as políticas de segurança no Brasil. Katálysis, Florianopólis, SC, v.9, n.1, p 38-42, jan/jun 2006.

BAZEMORE, G. (2006) Os jovens, os problemas e o crime. Justiça restaurativa como teoria normativa de controle social informal e apoio social. In: SLAKMON, C.; MACHADO, M.R.; BOTTINI, P. C. (Orgs). Novas direções na governança da justiça e da segurança. BrasíliaDF: Ministério da Justiça. 
BECK, U. Risk society. 1992 [1986] Towards a new modernity. Londres: Sage Publications,. 260p.

BENEDETTI, J. C. (2006) A justiça restauradora em face da criminologia da reação social. In: SLAKMON, C.; MACHADO, M.R.; BOTTINI, P. C. (Orgs). Novas direções na governança da justiça e da segurança. Brasília/DF: Ministério da Justiça.

BLACK, Donald; BAUMGARTNER, M. P. (1993). Toward a theory of the third party. In: BLACK, D. A social structure of right and wrong. New York: Academic Press, p. 95-124.

BRAITHWAITE, John. (2002) Restorative justice and respondive regulation. New York: Oxford University Press, 2002.

CAMPOS, Carmen Hein de. (2002) Justiça consensual e violência doméstica. Textos Bem Ditos, Porto Alegre: Themis, v. 1.

. (2004) Juizado Especial Cível e a democratização do acesso à justiça. XXVIII Encontro Anual da ANPOCS, Anais. Caxambu, MG, 26-28 out. 2004.

CUNHA, Luciana G. (2001) Juizado Especial: ampliação do acesso à justiça? In: SADEK, M. T. (Org.) Acesso à justiça. São Paulo: Fundação Konrad Adenauer.

BLAGG, H. (1997) " A just measure of shame? Aboriginal youth and conferencing in Australia” British Journal of Criminology, 37:481-501.

BLUMER, Herbert. (1986) Symbolic Interacionism: perspective and method. California: California University Press, 208p.

BONELLI, Maria da Gloria. (1998) A competição profissional no mundo do Direito. Tempo Social, São Paulo: USP, v.10, n.1, p185-214, maio.

CAPPELlETTI, Mauro; GARTH, Bryant. (1998) Acesso à justiça. Porto Alegre: Sergio Antonio Fabris, 168 p.

CARDOSO DE OLIVEIRA, Luís Roberto. (1995) Direito legal e insulto moral. Dilemas da cidadania no Brasil, Quebec e EUA. Rio de Janeiro: Relume Dumará/Núcleo de Antropologia da Política, 2002. [Coleção Antropologia da Política, 14]. Rio de Janeiro: Forense.

CASTANHO e OLIVEIRA; PAVEZ; SCHILLING (2002) Reflexões sobre justiça $e$ violência: o atendimento a familiares de vítimas de crimes fatais. Educ.

CAVALCANTI, Rosângela B. (1999) Cidadania e acesso à justiça: promotorias de justiça da comunidade. São Paulo/IDESP: Sumaré, 115p.

CRUIKSHANK, Barbara. (1994) The will of power: technologies of citizenship and the war on poverty. Socialist Review, 23 (4), p. 29-5.

DALY, K., (2000) Revisiting the relationship between Retributive and Restorative Justice, in Strang, H., Braithwaite, J. (Eds), Restorative Justice : from Philosophy to Practice, 33-54, Dartmouth, Ashgate, 33-54. 
2002a, Restorative Justice: The Real Story, Punishment and Society, 4, 1,

$55-79$.

2002b, Mind the Gap : Restorative Justice in Theory and Practice, in von Hirsh, A., Roberts, J., Bottoms, A.E., Roach, K., Schiff, M. (Eds), Restorative Justice \& Criminal Justice. Competing or Reconcilable Paradigms ?, Oxford et Portland, Oregon, Hart Publishing, 219-236.

D’ARAÚJO, Maria C. (1996) Juizados Especiais de Pequenas Causas: notas sobre a experiência no Rio de Janeiro. Estudos Históricos, v.9, n.18: 301-322.

DEBERT, Guita G.; OLIVEIRA, Marcella B. de. (2004) Os modelos conciliatórios de solução de conflitos e a violência doméstica. XXVIII. Encontro Anual da ANPOCS. Anais. Caxambu, MG, 26-28 out.

DUFF, A., (2003), Restoration and Retribution, in Von Hirsh, A., Roberts, J., Bottoms, A., Roach, K., Schiff, M. (Eds), Restorative Justice \& Criminal Justice. Competing or Reconcilable Paradigms ?, Oregon, Hart Publishing, Oxford et Portland, 43-59.

DURKHEIM, E. (2002) As regras do método sociológico. São Paulo: Martin Claret.

ENGELMANN, F. (2006) Internacionalização e Ativismo Judicial: As causas coletivas. Revista Lua Nova, n.69. p.123-146.

FAGET, Jacques. (2006). The french phantoms of restorative justice: the institutionalization of 'penal mediation'. In: AERTSEN, Ivo; DAEMS, Tom; ROBERT, Luc (Eds.). Institutionalizing restorative justice. Cullompton, Devon and Portlan: Willan Publishing Press, 313p.

FAISTING, André L. (1999) O dilema da dupla institucionalização do Poder Judiciário: o caso do Juizado Especial de Pequenas Causas. In: SADEK, M. T. (Org.). O sistema de justiça. São Paulo: Sumaré.

FALCÃO Neto, Joaquim de A. (1981) Cultura jurídica e democracia: a favor da democratização do judiciário. In: LAMOUNIER, B.; WEFFORT, F.; BENEVIDES, M. V. Direito, cidadania e partcipação. São Paulo: Tao.

FALK MOORE, Sally. (2006) Political struggles in legal arenas. Inclusion and exclusion in the global arena. Max Kirsch: Routledge.

FOLLETT, Mary P. (1930) Creative experience. Longmans, green and co. USA.

FOUCAULT, Michel. (2001) Os anormais. São Paulo: Martins Fontes. 480p.

FREIDSON, Eliot. (2001) Professionalism, the third logic: on the practice of knowledge. Chicago: Chicago Press, 250p. 
FROESTAD, Jan; SHEARING, Clifford. (2005) Prática da Justiça - O modelo Zwelethemba de Resolução de Conflitos. In: SLAKMON (Org) et al. Justiça Restaurativa. Brasília, DF: MJ e PNUD. Pp. 79-123.

FULLIN (2011). Quando o negócio é punir: uma análise etnográfica dos juizados especiais criminais e suas sanções. Tese. Doutorado em Antropologia Social. Universidade de São Paulo, 2011.

GARAPON, Antoine. (1997) Bien juger: essai sur le rituel judiciaire. Paris: Odile Jacob,.

GARAPON, A.; PAPAPOULOS, I. (2008) Julgar nos Estados Unidos e na França: cultura jurídica francesa e common law em uma perspectiva comparada. Trad: Vasconcelos, R. Rio de Janeiro: Lúmen Júris, 277p.

GARCIA, M. (2013) La théorie de la rationalité pénale moderne: un cadre d'observation, d'organisation et de description des idées propres au système de droit criminel In: $L a$ rationalité pénale moderne: réflexions théoriques et explorations empiriques. Dubé; Garcia et Machado (orgs). Les Presses de 1’Université d’Ottawa.

GARLAND, David. (1999) As contradições da "sociedade punitiva": o caso britânico. Revista de Sociologia e Política, Universidade Federal do Paraná: Curitiba, Brasil, n. 13, p. 59-80, nov. . (2008) A cultura do controle. Rio de Janeiro: Revan.

GIDDENS, A; LASH, S. (1994) Reflexive modernization. Politics, traditions and aesthetics in the modern social order. Cambridge: Polity Press, 225p.

GOMES PINTO, Renato S. (2005) Justiça restaurativa é possível no Brasil? In: SLAKMON, C., DE VITTO, R.; GOMES PINTO, R. (Orgs.). Justiça Restaurativa. Brasília: Ministério da Justiça/PNUD.

GUILLAUME-HOFNUNG, Michèle. (2009) La médiation. Que sais-je? Paris, France: Puf.

GULIVER, P. H. (1979) Disputes and negotiations. New York: Academic Press.

HALLSWORTH, S. (2012) A questão de uma punição pós-moderna. In: Ambivalência, contradição e volatilidade no sistema penal. CÂNEDO, C; FONSECA, D. S. (Orgs.). Minas Gerais/UFMG: Ed. Humanitas.

HALLIDAY, T. (1987) Beyond Monopoly : Lawyers, State Crises, and Professional Empowerment. University of Chicago Press. 388p.

(1999) Politics and civic professionalism: legal elites and cause lawyers. Law and Social Inquiry, n 24, pp. 1013-1060.

HARRISON, A., MERIC, M. et DIXON, A. (1995), Justice and Healing in Sheshatshit and Davis Inlet. A Report by Peace Brigades Internationl, document en ligne.

IBGE. Instituto Brasileiro de Geografia e Estatísitca. Disponível em: www.ibge.gov.br. Acesso em: 10/07/2013 
ILANUD/BRASIL. Sistematização e avaliação de experiências de justiça restaurativa. Relatório Final, 31 jan. 2006.

IZUMINO, Wânia P. (2003) Justiça para todos: os Juizados Especiais Criminais e a violência de gênero. Tese. Doutorado em Sociologia. Faculdade de Filosofia, Letras e Ciências Humanas. USP.

JACCOUD, Myléne. (2005) Princípios, tendências e procedimentos que cercam a justiça restaurativa. In: SLAKMON, C., DE VITTO, R; GOMES PINTO, R. (Orgs.). Justiça restaurativa. Brasília: Ministério da Justiça/PNUD.

(2007) «Innovations pénales et justice réparatrice », Champ pénal/Penal field [En ligne], Séminaire Innovations Pénales, mis en ligne le 29 septembre 2007, consulté le 17 juin 2014. URL: http://champpenal.revues.org/1269 ; OI:10.4000/champpenal.1269

(1999) Les cercles de guérison et les cercles de sentence autochtones au Canada Revue: Criminologie, Volume 32, numéro 1, printemps 1999, p. 7-105. http://id.erudit.org/iderudit/004725ar

JUNQUEIRA, Eliane. (1996) Acesso à justiça: um olhar retrospectivo. Estudos Históricos, n.18, p. 389-402.

KANT de LIMA, Roberto. (1989) Cultura jurídica e práticas policiais: a tradição inquisitorial. Revista Brasileira de Ciencias sociais, n.10, v.4, 65-84, jun.

(2004) Os cruéis modelos jurídicos de controle social. Insight Inteligência, Rio de Janeiro, ano 7, n. 25, p. 131-147, abr./maio/jun.

KARAM, Marta L. (2004) Juizados Especiais Criminais: a concretização antecipada do poder de punir. São Paulo: Revista dos Tribunais.

LINDSTROM, Peter (2003). Zero Tolerance Criminal Policy and Restorative Justice: A Hidden Link? In, Elmar Weitekamp and Hans-Jurgen Kerner, eds. Restorative Justice in Context: International Practice and Directions.Devon, UK and Portland Oregon: Willan Publishing. Pp. 285-303.

MARSHALL, Thomas, H. (1967) Cidadania, classe social e status. Rio de Janeiro: Zahar, $274 p$.

MATTHEWS, Roger. (2003) Reintegrative shaming and restorative justice: reconciliation or divorce? In: Wertekamp, Elmar, G.M.; Kerner, Hans-Jurgen. Restorative Justice in Context: International practice and directions. Willan Publishing, USA and Canada.

MAXWELL, Gabrielle; MORRIS, Allison(2001). Restorative justice for juveniles: Conferencing, mediation and circles. With a foreword by DJ Carruthers. Oxford: Hart Publishing. 
MCINTOSH, T. (2012) Maori Sociology in New Zealand In: Global Dialogue Volume 2 Issue 3.

MELO, Eduardo R. (2005) Justiça restaurativa e seus desafios histórico-culturais: um ensaio crítico sobre os fundamentos ético filosóficos da justiça restaurativa em contraposição à justiça retributiva. In: SLAKMON, C., DE VITTO, R; GOMES PINTO, R. (Orgs.). Justiça restaurativa. Brasília: Ministério da Justiça/PNUD.

(2006) Comunidade e justiça em parceria para a promoção de respeito e civilidade nas relações familiares e de vizinhança: um experimento de justiça restaurativa e comunitária. Bairro Nova Gerty, São Caetano do Sul/SP. Novas direções na governança da justiça e da segurança. Ministério da Justiça/Secretaria da Reforma do Judiciário.

(2008) A experiência em justiça restaurativa no Brasil: um novo paradigma avançado na infância e juventude. Revista IOB de Direito Penal e Processual Penal, Porto Alegre, ano IX, n.51, p.150-154, ago./set.

MELO, E.R; EDNIR, M; YAZBEK, V. C. (2008) Secretaria Especial dos Direitos Humanos da Presidência da República. Rio de Janeiro: CECIP, 192 p

MELLO, Kátia S. (2007) Igualdade e hierarquia no espaço público: análise de processos de administração institucional de conflitos no município de Niterói. Niterói: UFF, 2007. Tese. Doutorado em Antropologia. Universidade Federal Fluminense: UFF.

MIRAGLIA, Paula. (2005) Aprendendo a lição: uma etnografia das Varas Especiais da Infância e Juventude. Novos Estudos, CEBRAP, n.72, p.79-98, jul.

NADER, Laura. (1994) A civilização e seus negociadores: a harmonia como técnica de pacificação. Conferência de abertura da XIX Reunião da Associação Brasileira de Antropologia - ABA. Niterói: RJ.

. (1994) Harmonia coerciva: a economia política dos modelos jurídicos. Revista Brasileira de Ciências Sociais, n.29, ano 9, p. 18-29.

OLIVEIRA, Marcella Beraldo de. (2006) Crime invisível: mudança de significados da violência de gênero no Juizado Especial Criminal. Dissertação. Mestrado em Antropologia Social. Universidade Estadual de Campinas, UNICAMP.

(2010) Justiças do diálogo: uma análise da mediação extrajudicial. Tese. Doutorado em Ciências Sociais. Universidade Estadual de Campinas, UNICAMP.

OLSON, S. M. e DZUR, A. W. (2004) Revisiting informal justice: Restorative justice and democratic professionalism. Law \& Society Review, vol.38, nº1, p.139-76, 2004.

O'MAHONY, David and DOAK, Jonathan (2004). Restorative Justice -- Is More Better?: The Experience of Police-Led Restorative Cautioning Pilots in Northern Ireland Howard Journal of Criminal Justice. 43(5):484-505.

ORGANIZAÇÃO DAS NAÇÕES UNIDAS-ONU. Resolução 12/2002. Disponível em: www.onu.org.br. Acesso em: 30 ago 2012. 
OZORES (2011). Conflitos no campo jurídico em torno da profissionalização da mediação judicial. Dissertação. Mestrado em Sociologia. Universidade Federal de São Carlos, 2011.

PALLAMOLLA, Raffaella da P. (2009) Justiça restaurativa: da teoria à prática. São Paulo: IBCCRIM.

PAULA, Liana de. (2011) Liberdade Assistida: punição e cidadanioa na cidade de São Paulo. Tese de doutorado, Universidade de São Paulo.

PAVARINI, Massimo. (2002) Da perda da pena ao seu reencontro: reflexões sobre uma "procura" In: ZOMER, Ana Paula (Org.). Ensaios criminológicos, São Paulo: IBCCrim, p.91125.

PEDROSO, J; TRINCÃO, C; DIAS, J. P. (2001) Percursos da informalização e da desjudicialização - por caminhos da reforma administração da justiça (análise comparada). Observatório Permanente da Justiça Portuguesa, Centros de Estudos Sociais, Universidade de Coimbra.

PIRES, A. (2013) Postface In: La rationalité pénale moderne: réflexions théoriques et explorations empiriques. Dubé; Garcia et Machado (orgs). Les Presses de 1'Université d'Ottawa.

ROSE, Nikolas. (2000) Government and control. British Journal of Criminology, v. 40, p. 321-339.

RAUPP, M.; BENEDETTI, J. C; (2007) A implementação da justiça restaurativa no Brasil: uma avaliação dos programas de justiça restaurativa de São Caetano do Sul, Brasília e Porto Alegre. Revista Ultima Ratio. Rio de Janeiro: Lúmen Júris, ano 1, n.1.

RIBEIRO, Ludmila M. L.; CRUZ, Marcos Vinícius G.; BATITTUCCI, Eduardo C. (2004) Liberdade yutelada: a normalização e a burocratização da transação penal nos Juizados Especiais Criminais: estudo de caso de Belo Horizonte/MG. XXVIII. Encontro Anual da Anpocs. Anais. Caxambu, MG, 26-28 out.

ROCHE, D. (2007) Retribution and restorative justice. In: VAN NESS, Daniel W (Ed.). Handbook of restorative justice. Cullompton, UK; Portland, USA: Willan Publishing, p.7590.

SALAMANCA, Andrés B. (2004) Justicia Privada. Revista de Derecho, Valdivia, vol. 16, p. 165- 186, jul.

SAPORI, L. F. (2006) A Justiça Criminal Brasileira como um sistema frouxamente articulado. In: Slakmon, Catherine; Machado, Maíra Rocha; Bottini, Pierpaolo Cruz. (Org.). Novas direções na governança da justiça e da segurança. Brasília: Artcor Gráfica e Editora, v. 01, p. 256. 
SADEK, Maria Tereza. (2002) Estudos sobre o sistema de justiça. In: MICELI, Sergio (Org.) O que ler na ciência social brasileira, São Paulo: ANPOCS: Sumaré; Brasília: CAPES, v. 4, p. 233-265.

(2004) Judiciário: mudanças e reformas. Estudos Avançados, São Paulo, v.18, n.51, p.79-101, mai/ago 2004. (2001) Acesso à justiça. São Paulo: Fundação Konrad Adenauer. 277p.

SALM, João; LEAL, Jackson da Silva. (2012) A justiça restaurativa: multidimensionalidade e seu convidado de honra. Revista Sequiência. UFSC, Florianópolis, SC, Brasil, V. 33 n. 64 .

SANTOS, Boaventura de S. (2007) Para uma revolução democrática de justiça. São Paulo: Cortez, 120p.

SANTOS, M. Cecília Mac Dowell dos. (1989) Juizados informais de conciliação. Revista da Ordem dos Advogados do Brasil. São Paulo, n. 50, p.104-126.

SCHIMIDT (2010). Práticas restaurativas comunitárias: um olhar psicodramático sobre o lugar do jovem nos círculos restaurativos. Dissertação. Mestrado em Psicologia Social. Pontifícia Universidade Católica de São Paulo, 2010.

SCHRITZMEYER, Ana Lúcia P. (2001) Controlando o poder de matar: uma leitura antropológica do tribunal do júri-ritual lúdico e teatralizado. Tese de doutorado. São Paulo: USP/FFLCH, 2001. v. 21, n. 2, p. 70-79, jul./dez. 2007.

(2007) Afetos em jogo nos tribunais do júri. São Paulo em Perspectiva,

SCHUCH, Patrice. (2006) Direitos e afetos: análise etnográfica da justiça restaurativa no Brasil. ANPOCS, Anais. Caxambu, MG, 24-28 out.

. (2008) Tecnologias da não violência e modernização da Justiça no Brasil:

o caso da justiça restaurativa. Civitas, v. 8, p. 498-520, 2008.

SCOTT, James C. (1990) Domination and the arts of resistance. Yale University Press. 272p.

SIMMEL, Georg. (1964), Conflict. (Translation by Kurt H. Wolff). Nova York: The Free Press, pp. 13 a 17.

SIMIÃO, Daniel Schroeter; CARVALHO, Natan Ferreira de; DUARTE, Vitor Barbosa. (2007) Formas alternativas de resolução de conflitos em Belo Horizonte: mapeando um campo, seus dilemas e seus valores. VII. Reunião de Antropologia do MERCOSUL, Porto Alegre.

SICA, Leonardo. (2007) Justiça restaurativa e mediação penal: o novo modelo de justiça criminal e de gestão do crime. Rio de Janeiro: Lúmen Júris, 263p.

SINHORETTO, J. (2011) A justiça perto do povo. Reforma e gestão de conflitos. São Paulo: Alameda, 438 p. v. 1. 
SLAKMON, C., DE VITTO, R; GOMES PINTO, R. (Orgs.) (2005) Justiça restaurativa. Brasília: Ministério da Justiça/PNUD.

TONCHE, Juliana. (2007) Internacionalização do saber jurídico e poder local: o caso da justiça restaurativa em São Carlos-SP. Monografia de Conclusão de Curso. Ciências Sociais, Centro de Educação e Ciência Humanas (CECH), UFSCar.

(2010) Internacionalização do saber jurídico e redes profissionais locais: um estudo sobre justiça restaurativa em São Carlos (SP) e São Caetano do Sul (SP). Dissertação. Mestrado em Sociologia, UFScar, 2010.

VIANNA, L. Werneck et al. (1999) A judicialiazação da política e das relações sociais no Brasil. Rio de Janeiro: Renavan, 1999.

YOUNG, Richard. (2001) "Just cops doing 'shameful' business?: Police-led restorative justice and the lessons of research." In Restorative justice for juveniles: Conferencing, mediation and circles, ed. Allison Morris and Gabrielle Maxwell, 195-226. With a foreword by DJ Carruthers. Oxford: Hart Publishing.

ZEHR, Howard. (2008) Trocando as lentes: um novo foco sobre o crime e a justiça. São Paulo: Palas Athena, 276 p.

(2012) Justiça Restaurativa. São Paulo: Palas Athena, 2012.

ZERNOVA, M.; WRIGHT, M. (2007) Alternative visions of restorative justice. In: Gerry; Van Ness (ed). Handbook of restorative justice. Cullompton, UK; Portland, USA: Willan Publishing, p.91-108. 


\section{Anexos}

\section{Lista dos entrevistados:}

Foram doze interlocutores (houve dois encontros com um mesmo entrevistado): Um juiz de uma vara de infância e juventude de São Paulo, foi responsável pelo programa em Heliópolis; diretor de uma escola pública do município de Campinas-SP, que passou por uma capacitação para a aplicação do modelo alternativo em sua escola; uma facilitadora de justiça de uma escola pública do município de São Caetano do Sul-SP; a coordenadora do Núcleo Cultura da Paz da ONG CECIP (Centro de Criação de Imagem Popular), que participa da implementação de programas de justiça restaurativa pelo país; o representante da CNV (Comunicação Não-Violenta) no Brasil; uma mediadora psicóloga que realiza capacitações; uma representante da Secretaria de Educação de São José dos Campos-SP; três representantes da equipe de justiça restaurativa do FUNDHAS (Fundação Hélio Augusto de Souza de São José dos Campos); uma ex-facilitadora de justiça e a presidente do Conselho Municipal dos Direitos da Criança e do Adolescente de São Paulo-SP, que esteve envolvida com o programa de Heliópolis e, finalmente, uma assistente social de São Caetano do Sul. 


\section{Lista dos workshops e seminários:}

1. Workshop "Justiça Restaurativa: princípios, valores e prática" - realizado pela equipe "Justiça em Círculo", no dia 01 de junho de 2012 (São Paulo).

2. Seminário Internacional "Justiça Restaurativa: um novo paradigma" aconteceu no edifício do Ministério Público do Estado de São Paulo, no dia 19 de junho de 2012 (São Paulo).

3. Seminário "Justiça Restaurativa em caso de abuso sexual intrafamiliar em crianças e adolescentes" - aconteceu dia 29 de junho de 2012, na Sede Sapientiae (São Paulo).

4. Seminário "Métodos consensuais de solução de conflitos - rumos da resolução 125 - do CNJ', realizado no dia 27 de agosto de 2012, na Faculdade de Direito da USP (São Paulo).

5. Participação no Seminário "Dimensões Subjetivas e Comunitárias na Construção da Justiça Restaurativa", realizado no dia 5 de abril de 2013, no Centro de Direitos Humanos e Educação Popular de Campo Limpo (CDHEP);

6. Participação na palestra "Justiça Restaurativa: Visão Comparada" de João Salm, realizada dia 07 de agosto de 2013 na Escola Paulista da Magistratuta;

7. Ingresso no Núcleo de Estudos de Justiça Restaurativa da Escola Paulista da Magistratura; os encontros do grupo de estudo começaram no dia 25 de setembro de 2013 e são quinzenais;

8. Participação no evento Responsabilidades e Políticas para/com a Adolescência e Juventude: Diálogos Interdisciplinares sediado no Memorial da América Latina dia 25 de outubro de 2013;

9. Participação no National Restorative Justice Symposium realizado em Banff, Alberta, Canadá entre os dias 16 e 23 de novembro de 2014;

10. Seminário do Núcleo de Estudos sobre o Crime e a Pena da FGV Direito SP: "10 anos de Justiça Restaurativa no Brasil: Boas Práticas em São Paulo”. 12 de março de 2015, em São Paulo.

11. Seminário dos Fóruns Permanentes de Políticas Públicas e Cidadania: “Justiça e Cidadania: velhos e novos desafios desafios do Judiciário Brasileiro" 07 de abril de 2015, Unicamp, Campinas. 
TABELA 1: O RANKING DAS CAPITAIS: ÍNDICE DE VULNERABILIDADE JUVENIL À VIOLÊNCIA (IVJ) - VULNERABILIDADE ALTA

\begin{tabular}{ccc}
\hline CAPITAL & POSIÇÃO NO RANKING & ÍNDICE DE VULNERABILIDADE \\
\hline Maceió (AL) & $13^{\mathrm{a}}$ & 0,496 \\
Porto Velho (RO) & $19^{\mathrm{a}}$ & 0,483 \\
Recife (PE) & $22^{\mathrm{a}}$ & 0,481 \\
Belém (PA) & $34^{\mathrm{a}}$ & 0,458 \\
Macapá (AP) & $40^{\mathrm{a}}$ & 0,455 \\
Teresina (PI) & $43^{\mathrm{a}}$ & 0,451 \\
& & \\
\hline
\end{tabular}

Fonte: IBGE / UERJ / MJ / Fórum Brasileiro de Segurança Pública, 2009

TABELA 2: O RANKING DAS CAPITAIS: ÍNDICE DE VULNERABILIDADE JUVENIL À VIOLÊNCIA (IVJ) - VULNERABILIDADE MÉDIA

\begin{tabular}{ccc}
\hline CAPITAL & POSIÇÃO NO RANKING & ÍNDICE DE VULNERABILIDADE \\
\hline Manaus (AM) & $59^{\mathrm{a}}$ & 0,433 \\
Rio de Janeiro (RJ) & $64^{\mathrm{a}}$ & 0,429 \\
Cuiabá (MT) & $66^{\mathrm{a}}$ & 0,427 \\
São Luís (MA) & $67^{\mathrm{a}}$ & 0,427 \\
Fortaleza (CE) & $68^{\mathrm{a}}$ & 0,427 \\
Salvador (BA) & $84^{\mathrm{a}}$ & 0,410 \\
João Pessoa (PB) & $89^{\mathrm{a}}$ & 0,406 \\
Rio Branco (AC) & $96^{\mathrm{a}}$ & 0,400 \\
Aracaju (SE) & $103^{\mathrm{a}}$ & 0,395 \\
Boa Vista (RR) & $104^{\mathrm{a}}$ & 0,394 \\
Belo Horizonte (MG) & $105^{\mathrm{a}}$ & 0,393 \\
Vitória (ES) & $107^{\mathrm{a}}$ & 0,391 \\
Curitiba (PR) & $111^{\mathrm{a}}$ & 0,384 \\
Palmas (TO) & $120^{\mathrm{a}}$ & 0,377 \\
& & \\
\hline
\end{tabular}

Fonte: IBGE / UERJ / MJ / Fórum Brasileiro de Segurança Pública, 2009 
TABELA 3: O RANKING DAS CAPITAIS: ÍNDICE DE VULNERABILIDADE JUVENIL À VIOLÊNCIA (IVJ) - VULNERABILIDADE BAIXA

\begin{tabular}{ccc}
\hline CAPITAL & POSIÇÃO NO RANKING & ÍNDICE DE VULNERABILIDADE \\
\hline Campo Grande (MS) & $148^{\mathrm{a}}$ & 0,352 \\
Natal (RN) & $152^{\mathrm{a}}$ & 0,351 \\
Florianópolis (SC) & $157^{\mathrm{a}}$ & 0,346 \\
Porto Alegre (RS) & $161^{\mathrm{a}}$ & 0,342 \\
Goiânia (GO) & $163^{\mathrm{a}}$ & 0,338 \\
Brasília (DF) & $172^{\mathrm{a}}$ & 0,334 \\
São Paulo (SP) & $192^{\mathrm{a}}$ & 0,325 \\
\hline
\end{tabular}

Fonte: IBGE / UERJ / MJ / Fórum Brasileiro de Segurança Pública, 2009

As cidades com índice de até 0,300 são consideradas de vulnerabilidade baixa. De 0,300 a 0,370 vulnerabilidade média-baixa. Mais de 0,370 a 0,450 , vulnerabilidade média. Mais de 0,450 a 0,500, vulnerabilidade alta. E mais de 0,500 é considerado como vulnerabilidade muito alta.

As cidades com maior quantidade de jovens vulneráveis à violência são Itabuna (BA), Marabá (PA), Foz do Iguaçu (PR), Camaçari (BA), Governador Valadares (MG), Cabo de Santo Agostinho (PE), Jaboatão dos Guararapes (PE), Teixeira de Freitas (BA), Serra (ES) e Linhares (ES).

Os municípios menos vulnerabilidade são, na ordem: São Carlos (SP), São Caetano do Sul (SP), Franca (SP), Juiz de Fora (MG), Poços de Caldas (MG), Bento Gonçalves (RS), Divinópolis (MG), Bauru (SP), Jaraguá do Sul (SC) e Petrópolis (RJ). O Índice de Vulnerabilidade Juvenil à violência (IVJ-Violência) é mais elevado fora das capitais. 